WHOI-87-43

\title{
Seabed Material Commodity and Resource Summaries
}

by

Porter Hoagland III and James M. Broadus

Woods Hole Oceanographic Institution

Woods Hole, Massachusetts 02543

October 1987

\section{Technical Report}

Prepared by the Marine Policy Center, Woods Hole Oceanographic Institution with funds from the Department of Commerce, NOAA, National Sea Grant College Program under grant Number NA86-AA-D-SG090 (WHOI project Number R/S-9) and The J. N. Pew, Jr. Charitable Trust.

Reproduction in whole or in part is permitted for any purpose of the United States Government. This report should be cited as: Woods Hole Oceanog. Inst. Tech. Rept., WHOI-87-43.

Approved for publication; distribution unlimited.

Approved for Distribution:

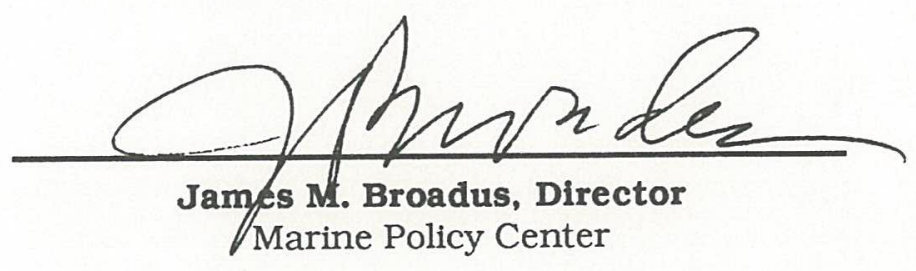



Over the past five years, research on marine minerals conducted by the Marine Policy Center at the Woods Hole Oceanographic Institution has attempted to gain a better understanding of the process by which these minerals are brought into productive use in society. This technical report results from concentrated research conducted by a research team under the primary sponsorship of the National Sea Grant College Program. This report provides background documentation for the recent publication: J.M. Broadus, 1987, "Seabed Materia1s," Science 235(4791): 853-860. It is organized to lead the user directly to sources that may provide further information on particular seabed materials. Several presentations of data in the report are of use in understanding the fundamentals of marine mineral markets including: descriptions of the size of the marine mineral resource base and the size of the markets for onshore and offshore sources of marine minerals; price series for minerals with prospective seabed sources; composite prices for four marine mineral types; consumption and price "elasticities" of mineral reserves; trends in mineral exploration inputs and U.S. federal government expenditures for marine nonfuel resources; maps of existing, proposed, or past entitlements for marine hard minerals; a list of known marine polymetallic sulfide (MPS) deposits and reported grades; world trade flows in zinc and copper; the value of apparent consumption in the United States in relation to imports and recycling; and a bibliography. 
The authors are greatly indebted to the following individuals for their contributions, comments, and suggestions: Andy Solow for the plots and curve fits in section III; Mike Mott1, Tim McConachy, Sarah Little, Cindy Van Dover, and Geoff Thompson for their feedback on the MPS locations and Rick Chandler for the Alvin dive data in section VII; Frank Manheim, Peter Bartlett, and Mike Cruickshank for their input on the material summaries in section II; the commodity specialists from the U.S Bureau of Mines (only some of whom are mentioned in the text) who were always willing to field questions; Frank Gable for a portion of the cartography in section VI; Bob Bowen for general comments and suggestions; and to Ellen Gately and Ethel LeFave for typing and proofreading. Ellen Gately receives extra thanks for her help in pulling the bibliography in section $\mathrm{X}$ together.

This project was influenced to a measurable extent by several other concurrent studies on marine minerals including work by Jim Curlin, Bill Westermeyer, Jim Mielke, and Rosina Bierbaum at the U.S. Office of Technology Assessment; Dave Ross and Thérèse Landry in their work with the National Research Council; and the participants at the 16th and 17th Underwater Mining Institute meetings. Special thanks go to Dave Duane and Bill Stubblefield for their guidance and encouragements from the National Sea Grant College Program at NOAA.

The authors accept all responsibility for errors or omissions. Comments, criticisms, and suggestions are heartily encouraged from all readers. 
TABLE OF CONTENTS

Section

$\underline{\text { Page }}$

I. Introduction . . . . . . . . . . . . . . . 1

II. Seabed Material Summaries . . . . . . . . . . . 5

III. Price Series . . . . . . . . . . . . . 35

IV. Elasticity of Reserves . . . . . . . . . . . 68

V. Trends in Exploration Inputs . . . . . . . . . . . 77

VI. Worldwide Locations, Entitlements, and Areas of Interest . . . 86

VII. MPS: Discovery, Location, and Generalized Composition . . . . 97

VIII. World Consumption, Production, and Trade in Zinc and Copper • . 126

IX. Value of U.S. Apparent Consumption, Imports and Recycling . . 148

X. Bibliography of Marine Minerals and Public Policy . . . . . 152 



\section{Section I: Introduction}

This technical report results from several years of concentrated research on seabed materials conducted by a research team led by principal investigator J.M. Broadus under the primary sponsorship of the National Sea Grant College Program. 1/ The title of this report has been borrowed from the title of the annual publication of the U.S. Bureau of Mines: Mineral Commodity Summaries (BOM/MCS). Since 1954, BOM/MCS and other Bureau of Mines' publications and reports have been the most current and comprehensive authorities avaliable to describe the world markets for the most important mineral commodities. This technical report attempts to supplement the efforts of the Bureau of Mines by focusing on seabed materials, some of which are not yet commodities in the strict sense of the term.

We have organized this report as a reference book. Examination of the figures and tables in the report will reveal the presentation of information that is unavailable from any other single source. The report does not attempt an evenhanded treatment of each seabed material (as in BOM/MCS) but instead

1/ Research projects sponsored by the National Sea Grant College Program include:

J.M. Broadus, 1982, "An Economic Analysis of Industrial Structure and Behavior in the Emerging Seabed Mining Industry," R/S-7.

J.M. Broadus, R.E. Bowen, and K.M. Shusterich, 1982, "Economic and Legal Aspects of Deepsea Polymetallic Sulfides," R/G-6.

J.M. Broadus, R.E. Bowen, and I. Pires, 1983, "Economic and Legal/Political Aspects of Polymetallic Sulfides," R/G-7.

D.A. Ross and J.M. Broadus, 1984, "The Relationship Between Natural Resource Characteristics, the Character of the Client Industry, and Optimal Resource Access Provisions: The Case of Marine Polymetallic Sulfides," R/G-9.

J.M. Broadus, 1986, "Economic and Legal-Political Implications of Mineral Resource Potential in the U.S. Exclusive Economic Zone: An Application of Lessons Learned in the Case of Polymetallic Sulfides," R/S-9.

Publications resulting from these research projects are referenced in the text of this report and listed in the bibliography. 
works to provide the most interesting and potentially useful information on selected seabed materials. The report is organized to lead the user directly to sources that may provide further information on a particular seabed material.

Generalizations and conclusions drawn from the data in this report can be found in the recent publication: J.M. Broadus, 1987, "Seabed Materials," Science 235(4791): 853-860. The report can be used as a background reference for that article. In particular, the tables presented in Section II of this report serve as compilations of data that were incorporated into Figure 1 of Broadus (1987). Sources for this data as well as for the price series presented in Section III are included in this report.

The research conducted by the Marine Policy Center over the past five years on marine minerals has attempted to gain a better understanding of the process by which these minerals are brought into productive use in society. This has involved an examination of the economic aspects of mineral discovery, exploration, development, and production including the identification and distribution of resources and reserves, technological capabilities and changes, and other factors that condition the supply of resources, namely conservation, substitution, recycling.

of course, no one reference material such as this report can hope to be fully comprehensive. We expect that the sources referred to in each section, as well as the bibliography of marine policy publications concerning marine minerals found in Section $\mathrm{X}$, will direct the reader to areas of interest that may not be covered fully in this report.

As an accumulation of information from a diverse set of primary sources, this technical report does not break new ground in the sense of gathering directly previously-unknown physical data on marine minerals. Nevertheless there are several presentations of data that we believe are unique and of significant value toward understanding the fundamentals of marine mineral markets and supply. These include:

Section II: The most up-to-date information available describing the size of the marine mineral resource base and the size of the markets for onshore and offshore sources of marine minerals. Except for diamond, this information is tabulated in Broadus (1987). 
Section III: The Potter and Christy (1962) and Manthy (1978) price series are updated for minerals with prospective seabed sources using the same sources of primary price data originally selected by Potter and Christy. Composite prices, which appear in Broadus (1987), are compiled here for four marine mineral types.

Section IV: As a different type of analysis of scarcity, consumption and price "elasticities" of mineral reserves over the period 1970 through 1985 are examined here.

Section V: Using a variety of sources, North American mineral exploration expenditures over the period 1961 through 1985 are estimated. Other trends in mineral exploration inputs are plotted using real 1983 prices in all cases. U.S. federal government expenditures for marine nonfuel resources during 1966 through 1986 are estimated.

Section VI: The world mineral resource map found in Broadus (1987) is referenced here. This map is an update using several sources that have appeared since the seminal effort of McKelvey and Wang (1970). This section also collects, in one place, maps of existing, proposed, or past entitlements for marine hard minerals.

Section VII: This section includes the most comprehensive list known of marine polymetallic sulfide (MPS) deposits with references, their legal jurisdictions, reported grades and a comparison to existing massive sulfide mines, and an estimate of discovery effort based upon submersible dives.

Section VIII: This section elucidates world trade flows in zinc and copper over a seventy-five year period from 1908 through 1983.

Section IX: This section examines the value of apparent consumption in the United States in relation to imports and recycling and compares this to the traditional "percentage measure" employed by the U.S. Department of the Interior. 
Section X: Over 1300 marine policy publications relating to marine minerals are listed in a bibliography.

More detailed descriptions of the data presented in each section are included at the beginning of each section. We welcome any comments, suggestions, additions, updates, or criticisms of this technical report. 
Section II: Seabed Material Summaries

Figure II-1 (Broadus, 1987) lists selected descriptive statistics for material commodities that have seabed deposit sources. The statistics have been collected from a number of reference works and published articles, which have been explained in detail in Summary Tables that follow the figure. The statistics have been standardized for ease of comparison. It should be noted the production of material commodities from seabed deposits has occurred for only a limited number of the listed commodities. Seabed production histories are mentioned in the Summary Tables.

The following key corresponds to the column headings in Figure II-2 and to the row headings in the Summary Tables:

Seabed production: This statistic is recent information on current production of material commodities from seabed deposits. This does not include past production, e.g., barite from the Castle Island, Alaska mine.

(B) World mine production: This statistic is recent information on current worldwide production of material commodities from all deposits. The U.S. Bureau of Mines' Mineral Commodity Summaries (1986) was the primary reference. This reference reports estimated 1985 world production. For hydrocarbons, figures reported by the U.S. Energy Information Administration (1986) were employed.

(C) Estimated average price: This statistic is recent information on average prices of material commodities. The U.S. Bureau of Mines' Mineral Commodity Summaries (1986) was the primary reference. The prices have been standardized in dollars per metric ton $(\$ / m t)$. It should be noted that most commodities are traded in units that differ from metric tons (e.g., troy ounces or pounds), and therefore this standardization may give a misleading impression of price.

Furthermore, average prices for some of the commodities with local markets (e.g., sand and gravel, shell, others) vary considerably depending upon the location of the market. Finally, to the extent possible, these are "minehead" prices, however, some reported average prices may contain varying amounts of transportation and processing costs.

(D) Seabed revenues: This statistic is the product of seabed production (column A) and estimated average price (column $\mathrm{C}$ ).

(E) World revenues: This statistic is the product of world mine production (column B) and estimated average price (column C). It should be interpreted only as a general indicator of the size of the markets for these commodities, considering the caveats mentioned already about estimated average price. Moreover, although mine production in many cases approximates consumption, no account has been taken here of stockpiling behavior, recycling, and other secondary sources. 
(F) Seabed share of world revenues: This statistic is seabed revenues (column D) expressed as a percentage of world revenues (column E).

(G) Seabed reported potential resources: Seabed resource estimates are taken from a number of references. Many of the estimates are limited only to the United States. The methods of estimating resources vary depending upon the resource, but most of the estimates reported here should be considered "speculative" or "hypothetical resources" (following the classification used by the U.S. Bureau of Mines and the U.S. Geological Survey). As noted by Broadus (1987), many of these estimates could expand through increased resource assessment efforts or even through a more comprehensive search of the literature.

(H) World onshore resources: This statistic is, in almost every case, an "identified resource." The U.S. Bureau of Mines' Mineral Facts and Problems (1980) and Mineral Commodity Summaries (1986) were the primary references. The 1985 edition of Mineral Facts and Problems was not used because Bureau of Mines has dropped the use of "identified resource" and now reports only "reserve base," a smaller classification.

(I) Seabed comparison to world resources: This statistic is seabed reported potential resources (column $G$ ) expressed as a percentage of world onshore resources (column H). Note that the categories of resources (speculative or hypothetical versus identified) are different. World onshore speculative and hypothetical resources should be much larger than the amounts reported in column G, and therefore in most cases a comparison of seabed to onshore would be smaller.

(J) Resource life index: This statistic is world onshore resources (column H) divided by world mine production (column B). Because world mine production is estimated over the course of one year (usually 1985), the units for this life index are in "years." Subject to several strong assumptions, the index roughly suggests a "waiting time" before seabed materials might be called into use but without considering either growth in consumption or substitution, recycling, conservation, and technological advance.

(K) Projected onshore depletion: This statistic indicates a projected depletion of onshore resources based upon the Leontief et al. (1984) input-output model of the world economy. The statistics show the percent of the 1980 world onshore resource that is depleted by the year 2030 using the pessimistic scenario of a low growth rate in the lesser developed countries (LDCs). Note that the depletion estimate is not bounded at 100\%. For example, $120 \%$ depletion indicates that 1.2 times the identified resource would be consumed by 2030 .

(L) Crustal abundance: For some of the material commodities, this statistic shows the crustal abundance in metric tons. This is the theoretical limit on the size of the resource in the earth's crust. (This statistic was not included in Figure 1.) 


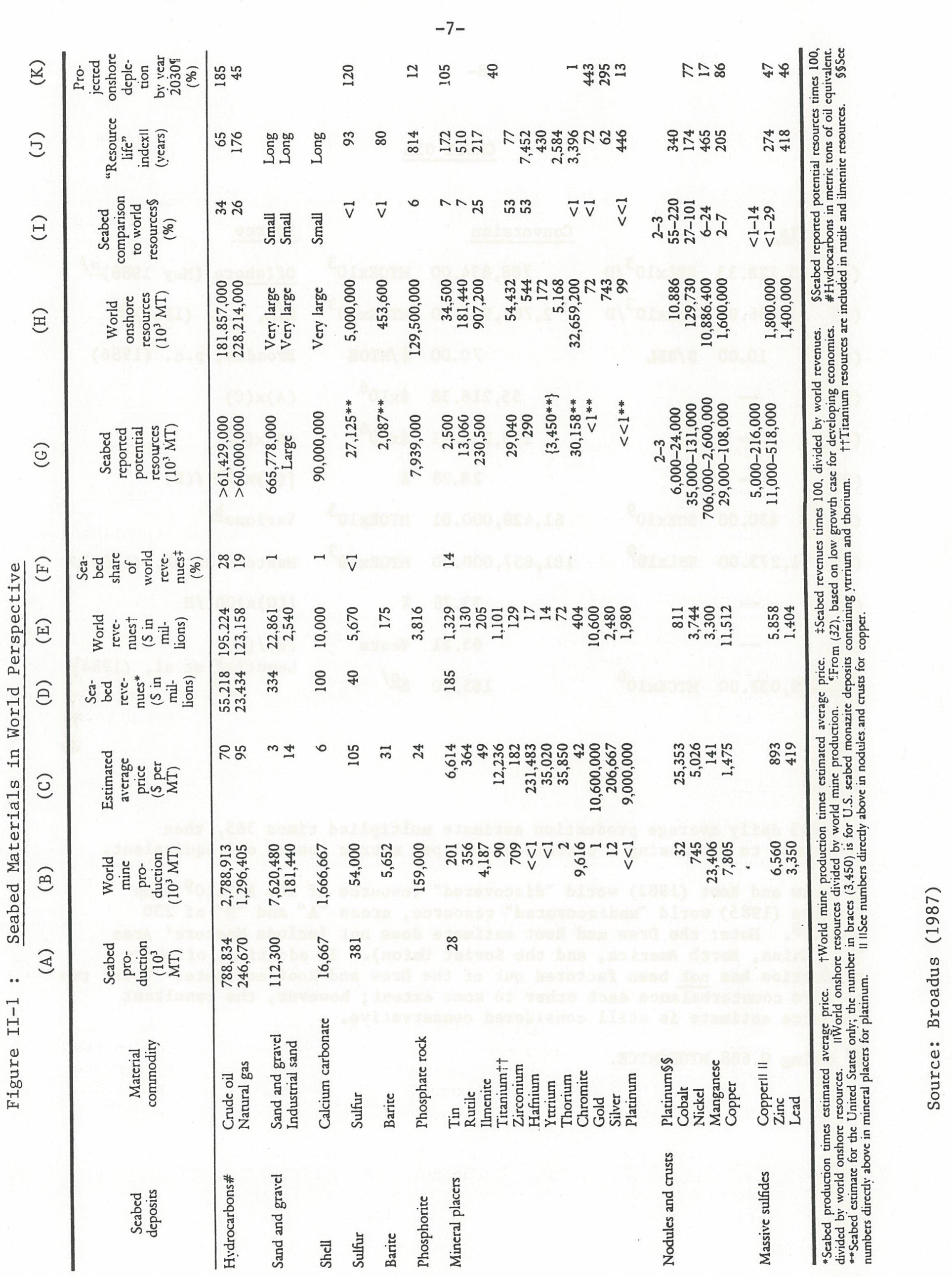


CRUDE OIL

Data
(A) $15,128.33 \quad \mathrm{BBLx} 10^{3} / \mathrm{D}$
(B) $53,486.00 \quad \mathrm{BBLx} 10^{3} / \mathrm{D}$
(C)
$10.00 \$ / B B L$
(D)
(E)
(F)
(G)
(H) $\quad 1,273.00 \quad$ BBLx $10^{9}$
( I)

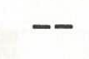
$(\mathrm{J})$
(K) $489,032.00 \operatorname{MTCEx} 10^{6}$ (L)

Conversion

\begin{tabular}{|c|c|c|}
\hline $788,834.00$ & $\operatorname{MTOEx} 10^{3}$ & Offshore (May 1986)a \\
\hline $2,788,913.00$ & $\operatorname{MTOEx} 10^{3}$ & EIA, p.c. (1986) al \\
\hline 70.00 & \$/MTOE & Broadus, p.c. (1986) \\
\hline $55,218.38$ & $\$ \times 10^{6}$ & $(A) \times(C)$ \\
\hline $195,223.91$ & $\$ \times 10^{6}$ & $(B) \times(C)$ \\
\hline 28.28 & $\%$ & {$[(D) \times 100] /(E)$} \\
\hline $61,429,000.01$ & $\operatorname{MTOEx} 10^{3}$ & Various b/ \\
\hline $181,857,000.00$ & $\operatorname{MTOEx} 10^{3}$ & Masters et al. (1983) \\
\hline 33.78 & $\%$ & {$[(G) \times 100] / H$} \\
\hline 65.21 & Years & $(\mathrm{H}) /(\mathrm{B})$ \\
\hline 185.00 & $\%$ l & 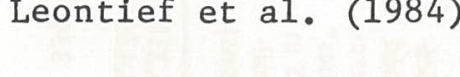 \\
\hline
\end{tabular}

Notes:

a/ 1985 daily average production estimate multiplied times 365 , then converted to MTOE using 7 barrels of oil per metric ton of oil equivalent.

b/ Drew and Root (1982) world "discovered" resource of 200 BoEx109 plus Masters (1985) world "undiscovered" resource, areas "A" and "B" of 230 BOEx109. Note: the Drew and Root estimate does not include Masters' Area "B" (China, North America, and the Soviet Union). In addition, offshore production has not been factored out of the Drew and Root estimate. These two factors counterbalance each other to some extent; however, the resultant resource estimate is still considered conservative.

c/ Using $0.688 \mathrm{MTOE} / \mathrm{MTCE}$. 
NATURAL GAS

Oxiginal Data

(A) $28,383.90 \mathrm{FT}^{3} \times 10^{6} / \mathrm{D}$

(B) $54,449.00 \mathrm{FT}^{3} \times 10^{9}$

(C) $2.25 \$ / \mathrm{FT}^{3} \times 10^{3}$

(D)

(E)

(F)

(G) $61,429.00$ MTOEx $10^{6}$

(H) $\quad 9,585.00 \mathrm{FT}^{3} \times 10^{12}$

(I)

(J)

(K) $150,370.00 \operatorname{MTCEx} 10^{6}$
Conversion

$246,670.00$ MTOE $\times 10^{3}$

$1,296,405.00 \mathrm{MTOEx} 10^{3}$

$95.00 \$ /$ MTOE

$23,433.65 \$ \times 10^{6}$

$123,158.47 \$ \times 10^{6}$

$19.03 \%$

$60,000,000.00$ MTOE $\times 10^{3}$

$228,214,000.00$ MTOEx $10^{3}$

$26.29 \%$

176.04 Years

$45.00 \%$
Source

Offshore (May 1986)a

EIA, p.c. $(1986)^{b}$

Broadus, p.c. (1986)

(A) $x(C)$

(B) $x(C)$

[(D) $\times 100] /(E)$

Various $^{c}$

BOM/MFP (1980)

$[(G) \times 100] / H$

(H) $/(\mathrm{B})$

Leontief et a1. (1984)e

(L)

\section{Notes:}

a 1983 average daily production multiplied times 365, then converted to BOE using BOE/6000 $\mathrm{FT}^{3}$ (Masters, p.c., 1986; Note: API conversion factor is BOE/ $5604 \mathrm{FT}^{3}$ ), then converted to MTOE using MTOE/7 BBL.

b Average annual production, converted as above.

c A good rule-of-thumb to estimate natural gas resources offshore is a $1: 1$ ratio, in terms of heat content (oil equivalents) with crude oil resources offshore (see: crude oil notes). The 61,429 MTOEx $10^{6}$ crude oil resource estimate is reduced slightly here to get a 60,000 MTOEx10 6 natural gas resource estimate because offshore resources tend to be slightly "oilier" than continental resources (Masters, p.c., 1986). In the past, discovered natural gas resources have been underreported because there were no markets.

d "Ultimate resources" defined as the Sum of cumulative production, proved reserves, and potential reserves.

e Using $0.688 \mathrm{MTOE} / \mathrm{MTCE}$. 
SAND AND GRAVEL

Data

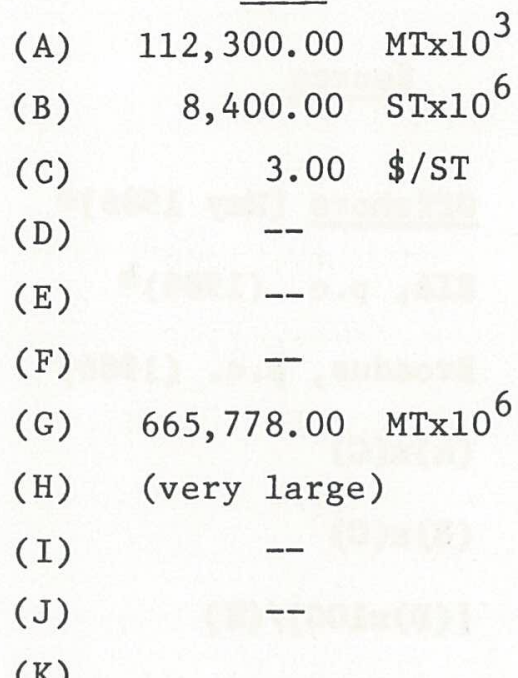

\section{Conversion}

\begin{tabular}{|c|c|c|}
\hline \multicolumn{2}{|l|}{ 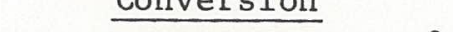 } & \\
\hline $112,300.00$ & $\operatorname{MTx} 10^{3}$ & Variousa/ \\
\hline $7,620,480.00$ & $\operatorname{MTx} 10^{3}$ & BOM/MFP (1985) \\
\hline 3.31 & $\$ / \mathrm{MT}$ & BOM/MCS (1986) \\
\hline 336.90 & $\$ \times 10^{6}$ & $(A) \times(C)$ \\
\hline $22,861.44$ & $\$ \times 10^{6}$ & $(B) \times(C)$ \\
\hline 1.47 & $\%$ & {$[(D) \times 100] /(E)$} \\
\hline $565,778,000.00$ & $\operatorname{MTx} 10^{3}$ & Various - / \\
\hline (very large) & $\operatorname{MTx} 10^{3}$ & BOM/MCS (1986) \\
\hline (sma11) & $\%$ & {$[(G) \times 100] / H$} \\
\hline (1ong) & Years & $(\mathrm{H}) /(\mathrm{B})$ \\
\hline
\end{tabular}

(L)

Notes:

a Sum of the following production figures:

\begin{tabular}{|c|c|c|c|}
\hline Country & $\operatorname{MTx} 10^{3}$ & Year & Source \\
\hline Japan & $\overline{54,000}$ & $\overline{1983}$ & Tsurasaki (1986) \\
\hline United Kingdom & 19,500 & 1985 & Uren (1986) \\
\hline Netherlands & 15,000 & 1984 & de Groot (1986) \\
\hline Denmark & 5,100 & 1983 & de Groot (1986) \\
\hline Canada & 5,000 & 1983 & de Groot (1986) \\
\hline France & 4,200 & 1982 & Galtier (1984) \\
\hline West Germany & 3,800 & 1984 & de Groot (1986) \\
\hline USA & 3,000 & 1980 & de Groot (1986) \\
\hline Finland & 1,400 & 1983 & de Groot (1986) \\
\hline Belgium & 700 & 1984 & de Groot (1986) \\
\hline Iceland & 500 & 1984 & de Groot (1986) \\
\hline Sweden & 100 & 1984 & de Groot (1986) \\
\hline
\end{tabular}

The de Groot and Galtier figures have been rounded. Production figures in the United States are difficult to estimate, because offshore mining activity occurs on a local or state level and, although sanctioned by the Army Corps of Engineers, offshore production figures are not aggregated nationally (Padan,J., 1986, Personal communication, Washington: Office of Ocean Minerals and Energy, NOAA, July). Galtier estimated 4,000 MTx $10^{3}$ U.S. offshore production in 1978 and de Groot estimated 3,400 MTx10 ${ }^{3}$ in 1980. Nevertheless, these figures should be regarded as highly uncertain.

b Sum of the following resource estimates:

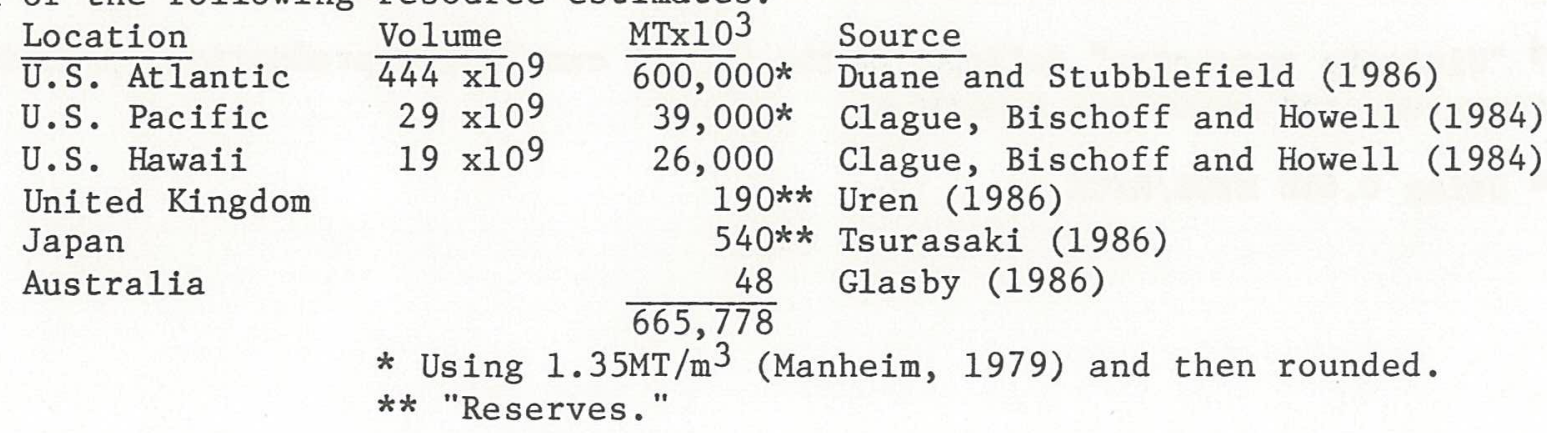


INDUSTRIAL SAND

\section{Data}

(A)

(B)

(C)

(D)

(E)

(F)

(G)

(H)

(I)

(J)

(K)

(L)

\section{Conversion}

$137,000.00 \mathrm{MT}$

$200.00 \quad \mathrm{STx} 10^{6}$

$12.90 \$ / \mathrm{ST}$
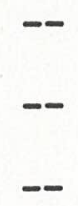

(Large)

(Very Large)

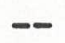

$-$

$$
137.00 \mathrm{MTx} 10^{3}
$$

$$
181,440.00 \quad \mathrm{MT}_{10} 0^{3}
$$

$14.22 \$ / M T$

$1,948.14 \$ \times 10^{3}$

$2,540.16 \$ \times 10^{6}$

$0.08 \%$

(large) $\mathrm{MT} 10^{3}$

(very large) $\mathrm{MTx}_{10}{ }^{3}$

(smal1) \%

(1ong) Years
Source

Glasby, $1986^{a}$

BOM/MFP (1985)

BOM/MCS (1986)

(A) $x($ C )

(B) $x(C)$

[(D) $\times 100] /(E)$

Estimate ${ }^{b}$

BOM/MFP (1985)

[(G) $\times 100] / H$

(H) $/(B)$

Notes:

a Dredging from Parengaenga Harbor, Northland, New Zealand (1979 Figure).

b Magdalen Silica, Inc. reports $250 \mathrm{~m}^{3} \times 10^{6}$ (roughly 338,000 MTx $10^{6}$ ) of recoverable silica sand off the Madeleine Islands, Gulf of St. Lawrence, Canada (Hale, 1984). 


\section{CALCIUM CARBONATE}

\begin{tabular}{|c|c|c|c|c|c|}
\hline & Data & & Conversion & & Source \\
\hline (A) & -- & & $16,666.67$ & $\operatorname{MTx} 10^{3}$ & Estimate ${ }^{a}$ \\
\hline (B) & -- & & $1,666,666.67$ & $\operatorname{MTx} 10^{3}$ & Estimate ${ }^{a}$ \\
\hline (C) & -- & & 6.00 & $\$ / \mathrm{MT}$ & Broadus (1985) \\
\hline (D) & -- & & 100.00 & $\$ \times 10^{6}$ & Glasby (1979) \\
\hline$(E)$ & -- & & $10,000.00$ & $\$ \times 10^{6}$ & Glasby (1979) \\
\hline (F) & -- & & 1.00 & $\%$ & {$[(D) \times 100] /(E)$} \\
\hline (G) & $\begin{array}{l}70,000.00- \\
90,000.00\end{array}$ & $\operatorname{MTx} 10^{6}$ & $\begin{array}{l}70,000,000.00- \\
90,000,000.00\end{array}$ & $\operatorname{MTx} 10^{3}$ & Earney $(1980)^{b}$ \\
\hline$(\mathrm{H})$ & (very large) & & (very large) & $\operatorname{MTx} 10^{3}$ & Estimate \\
\hline (I) & -- & & (sma11) & $\%$ & {$[(G) \times 100] / H$} \\
\hline$(\mathrm{J})$ & -- & & (long) & Years & $(\mathrm{H}) /(\mathrm{B})$ \\
\hline \multicolumn{6}{|l|}{$(\mathrm{K})$} \\
\hline \multicolumn{6}{|l|}{$(L)$} \\
\hline Note & & & & & \\
\hline
\end{tabular}

a Glasby (1979) reports the following data supplied by the Institute of Geological Sciences, London, England:

Country
United States
France
Iceland
Fiji
Bahamas
Others

\begin{tabular}{cc}
$\frac{\text { Seabed Production }}{(\text { MTx103) }}$ & $\frac{\text { Value }}{\left(\text { US } \$ \times 10^{6}\right)}$ \\
14,000 & 67.00 \\
900 & 25.00 \\
160 & 0.80 \\
80 & 0.10 \\
900 & 1.50 \\
250 & 0.80 \\
\hline 16,290 & 95.20
\end{tabular}

Broadus (1985) rounds $95.2 \$ \times 10^{6}$ to $100 \$ \times 10^{6}$ and estimates an average price of 6.00 \$/MT to derive similar seabed and world production estimates. Note: Glasby also estimates seabed production at less than one percent of world mine production.

b Bahamian offshore aragonite reserves. Note: Earney (1986) reports the existence of 35 years of she11 sand reserves in Iceland based on current production rates ( $115 \mathrm{~m}^{3} \times 10^{3} /$ year). Using Glasby's estimate for Icelandic production of $160 \mathrm{MTx} 10^{3}$ in 1977 , Iceland has an estimated $5.6 \mathrm{MTx} 10^{6}$ of she11 sand reserves $(35 \times 160)$. Glasby (1986) reports on Summerhayes' estimates of 1 MTx1014 of calcium carbonate on the Campbel1 Plateau, New Zealand, but he mentions also that: "it is unlikely that calcium carbonate will be mined off New Zealand within the foreseeable future." 
SULFUR

Data
(A) $380.95 \mathrm{MT} \times 10^{3}$
(B) $54,000.00 \quad \mathrm{MT} 10^{3}$
(C) $\quad 104.68 \$ / M T$
(D) -
(E) --
(F)
(G) $27,125.00 \quad \mathrm{MT} \times 10^{3}$
(H) $\quad 5.00 \quad \operatorname{MT} \times 10^{9}$
(I)

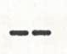
(J)
(K) $\quad 6,020.00 \quad \operatorname{MT} \times 10^{6}$
(L)

Conversion

$$
380.95 \operatorname{MT} \times 10^{3}
$$

Source

\begin{tabular}{|c|c|c|}
\hline 380.95 & $\operatorname{MTx} 10^{3}$ & Broadus (1985) \\
\hline $54,000.00$ & $\operatorname{MTx} 10^{3}$ & BOM/MCS (1986) \\
\hline 104.68 & $\$ / M T$ & BOM/MCS (1986) \\
\hline 40.01 & $\$ \times 10^{6}$ & (A) $x(C)$ \\
\hline $5,760.00$ & $\$ \times 10^{6}$ & $(B) \times(C)$ \\
\hline 0.69 & $\%$ & {$[(D) \times 100] /(E)$} \\
\hline $27,125.00$ & $\operatorname{MTx} 10^{3}$ & Carpenter, p.c. (1986a \\
\hline $5,000,000.00$ & $\operatorname{MTx} 10^{3}$ & BOM/MFP (1980) \\
\hline 0.54 & $\%$ & {$[(G) \times 100] / H$} \\
\hline 92.60 & Years & (H) $/(\mathrm{B})$ \\
\hline 120.40 & $\%$ & Leontief et al. (1984) \\
\hline
\end{tabular}

Notes:

a/ U.S. seabed "probable reserve" estimate, $17.5 \%$ of U.S. "probable reserve" estimate of $155 \mathrm{MTx} 10^{6}$. G. Carpenter, personal communication, Minerals Management Service, U.S. Department of the Interior, Reston, Virginia, July 28, 1986. 
BARITE

Data Conversion Source

(A)

(B)

(C)

$6,230.00 \quad \operatorname{STx} 10^{3}$

$5,651.90 \operatorname{MTx} 10^{3}$

BOM/MCS (1986)

$30.86 \$ / M T$

BOM/MCS (1986)

(D)

(E)

$175.21 \$ \times 10^{6}$

(B) $x(C)$

(F)

(G)

$2.30 \quad \operatorname{sTx} 10^{6}$

$2,086.56 \operatorname{MTx} 10^{3}$

Earney $(1980)^{a}$

$\left(\mathrm{H}_{1}\right)$

$500.00 \quad \operatorname{STx} 10^{6}$

$453,600.00 \quad \operatorname{MTx} 10^{3}$

BOM/MCS $(1986)^{b}$

$\left(\mathrm{H}_{2}\right)$

$2.00 \operatorname{sTx} 10^{9}$

$1,800,000.00 \quad \operatorname{MTx} 10^{3}$

BOM/MCS $(1986)^{b}$

$\left(I_{1}\right)$

$0.46 \%$

[(G) $\times 100] / \mathrm{H}_{1}$

$\left(I_{2}\right)$

$0.12 \%$

[(G) $\times 100] / \mathrm{H}_{2}$

$\left(\mathrm{J}_{1}\right)$

80.30 Years

$\left(\mathrm{H}_{1}\right) /(\mathrm{B})$

$\left(\mathrm{J}_{2}\right)$

$-$

318.48 Years

$\left(\mathrm{H}_{2}\right) /(\mathrm{B})$

(K)

(L)

$9.40 \operatorname{MTx} 10^{15}$

$9,400.00 \mathrm{MTx} 10^{12}$

Erickson $(1973)^{c}$

\section{Notes:}

a Barite deposit formerly in production at Castle Island, Alaska. This estimate includes cumulative production through 1975. The deposit occurs above and below sea level, but it was depleted first on the surface and then mined below sea level so that it is now considered a seabed deposit. Earney (1980) reports other barium sulfate concretions offshore San Clemente, California; the Kai Islands, Indonesia; and Colombo, Sri Lanka.

b $\mathrm{H}_{1}$ are identified resources. $\mathrm{H}_{2}$ are resources in all categories (including speculative and hypothetical).

c Barium. 


\section{PHOSPHATE ROCK}

$\underline{\text { Data }}$
(A)
(B)

$$
\begin{array}{cl}
(1.50 & \left.\operatorname{MTx} 10^{6}\right) \\
159,000.00 & \operatorname{MTx} 10^{3} \\
23.50 & \$ / \mathrm{MT} \\
-- & \\
-- & \\
-- & \\
7,873.00 & \operatorname{MTx} 10^{6} \\
129,500.00 & \operatorname{MTx} 10^{6} \\
-- & \\
-- & \\
16.10 & \operatorname{MTx} 10^{9}
\end{array}
$$
(D)$$
\text { 28. } 80 \operatorname{MTx} 10^{15}
$$

Conversion

Source

$\begin{array}{rll}(1,500.00 & \left.\text { MTx10 }^{6}\right) & \text { Yates et al. }(1986)^{a} \\ 159,000.00 & \text { MTx10 }^{3} & \text { BOM/MCS }(1986) \\ 23.50 & \$ / M T & \text { BOM/MCS }(1986) \\ (36.00 & \left.\$ \times 10^{6}\right) & (\text { A }) \times(C)^{a} \\ 3,816.00 & \$ \times 10^{6} & (\text { B }) \times(C) \\ (0.94 & \%) & {[(D) \times 100] /(E)^{a}} \\ 7,873,000.00 & \text { MTx10 }^{3} & \text { Various } \\ 129,500,000.00 & \text { MTx10 }^{3} & \text { BOM/MFP }(1980) \\ 6.08 & \% & {[(G) \times 100] / H} \\ 814.47 & \text { Years } & (\text { H }) /(B) \\ 12.40 & \% & \text { Leontief et a1. (1984) } \\ 28,800.00 & \text { MTx10 } 12 & \text { Erickson (1973) }\end{array}$

* Phosphorite is technically a heavy mineral.

a Yates, Spagni and Keane (1986) report offshore "phosphate sand" production at San Domingo, Baja California, Mexico by Roca Fosforica Mexicana S.A.d.C.V. (Rofomex), the national phosphate rock mining company. Offshore operations have since been terminated, however, due to the low grade ( $4-5 \%$ phosphate) and difficulties encountered in dredging the very hard, mixed phosphorite-calcium carbonate deposit (Stowasser, W.F., 1986, Personal communication, Washington: Bureau of Mines, U.S. Dept. of the Interior, July).

b Sum of the following resource estimates:

$\begin{array}{lrl}\text { Location } & \text { MTx106 } & \text { Source } \\ \text { U.S. Atlantic } & 4,500 & \text { Riggs (1985) } \\ \text { U.S. Pacific } & 115 & \text { Clague et al. (1984) } \\ \text { Chatham Rise, New Zealand } & 3,200 & \text { McKelvey (1986) } \\ \text { Baja California, Mexico* } & 50 & \text { Yates et a1. (1986) } \\ \text { South Africa } & 8 & \text { Bartlett (1986) }\end{array}$

Note: Mero (1965) estimated a resource of 300 MTx109 of phosphorites on the world's continental shelf. Assuming that 10 percent might be commercially recoverable, Roonwal (1986) estimates reserves of $30 \mathrm{MTx} 10^{9}$. 
TIN

Data

Conversion $\quad$ Source

\begin{tabular}{|c|c|c|c|c|c|}
\hline (A) & 28.00 & $\operatorname{MT} \times 10^{3}$ & 28.00 & $\operatorname{MTx} 10^{3}$ & Various a/ \\
\hline (B) & $201,000.00$ & $\mathrm{MT}$ & 201.00 & $\operatorname{MTx} 10^{3}$ & BOM/MCS (1986) \\
\hline (C) & 3.00 & $\$ / L B$ & $6,613.80$ & $\$ / M T$ & Broadus, p.c. (1986) \\
\hline (D) & -- & & 185.19 & $\$ \times 10^{6}$ & $(A) \times(C)$ \\
\hline ( $E)$ & -- & & $1,329.41$ & $\$ \times 10^{6}$ & (B) $x(C)$ \\
\hline$(F)$ & -- & & 13.92 & 8 & {$[(D) \times 100] /(E)$} \\
\hline (G) & $2,429.00$ & $\operatorname{MTx} 10^{3}$ & $2,500.00$ & $\operatorname{MTX} 10^{3}$ & Various \\
\hline ( $\mathrm{H})$ & $37,000.00$ & $\operatorname{MT} \times 10^{3}$ & $34,500.00$ & $\operatorname{MT} \times 10^{3}$ & $\mathrm{BOM} / \mathrm{MFP} \quad(1980)$ C \\
\hline ( I ) & -- & & 7.25 & 8 & {$[(G) \times 100] / H$} \\
\hline ( $\mathrm{J})$ & -- & & 171.64 & Years & $(\mathrm{H}) /(\mathrm{B})$ \\
\hline$(\mathrm{K})$ & $38,900.00$ & $\operatorname{MT} \times 10^{3}$ & 105.14 & 8 & Leontief et al. (1984) \\
\hline (L) & 40.80 & $\operatorname{MT} \times 10^{12}$ & 40.80 & $\operatorname{MT} \times 10^{12}$ & Erickson (1973) \\
\hline
\end{tabular}

Notes:

a/ Using U.N. Economic and Social Council (1985) estimates of seabed production as a share of total production in 1982 (dervied from Galtier, 1984):

\begin{tabular}{|c|c|c|c|}
\hline Location & $\begin{array}{c}\stackrel{(\mathrm{X})}{(1985)} \\
\frac{\text { Mine Production }}{\left(\text { MT } \times 10^{3}\right)}\end{array}$ & $\begin{array}{c}(\underline{Y}) \\
\text { Seabed } \\
\frac{\text { Production }}{(8 \text { of } X)}\end{array}$ & $\begin{array}{c}(\underline{z}) \\
\text { Seabed } \\
\text { Production } \\
\frac{\left(M T \times 10^{3}\right)}{(M}\end{array}$ \\
\hline Thailand & 20.00 & 60 & 12.00 \\
\hline Indonesia & 20.00 & 57 & 11.40 \\
\hline $\begin{array}{l}\text { United Kingdom } \\
\text { (Cornwall) }\end{array}$ & 4.60 & 100 & $\frac{4.60}{28.00}$ \\
\hline
\end{tabular}

b/ Sum of the following seabed resource estimates:

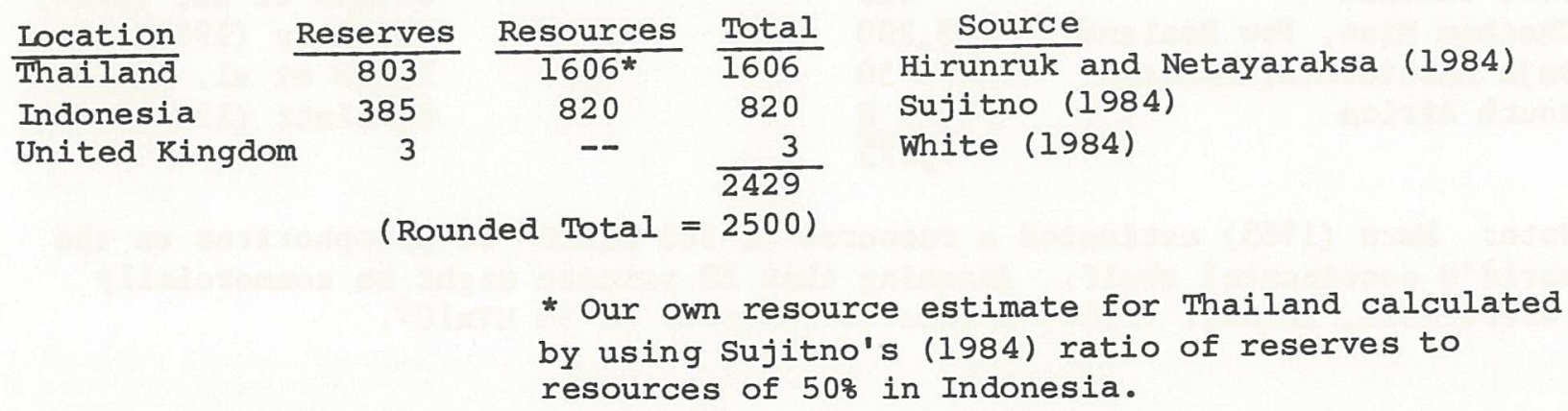

Cf Seabed resource estimate (G) subtracted from world onshore resource estimate of $37 \mathrm{MTx} 10^{6}$. 


\section{TITANIUM METAL}

$\underline{\text { Data }}$

(A)

(B) $99,000.00 \mathrm{sT}$

(C) $5.55 \$ / L B$

(D)

(E)

(F)

(G)

(H) $\left(697,483.00 \mathrm{MTx} 10^{3}\right)$

See: rutile and ilmenite

(I)

(J)

(K) $\quad 280,000.00 \mathrm{MT} \times 10^{3}$

(L) $\quad 153.60 \mathrm{MT} \times 1015$

See: rutile and ilmenite

See: rutile and ilmenite

$40.14 \%$

$153,600.00 \operatorname{MT} \times 10^{12}$

\section{Source}

BOM/MCS (1986)

BOM/MCS (1986)

(A) $x(C)$

(B) $x(C)$

[(D) $\times 100] /(E)$

BOM/MFP (1980)a

$[(\mathrm{G}) \times 100] /(\mathrm{H})$

(H) $/(\mathrm{B})$

Leontief $(1984) /(H)$

Erickson (1973)

\section{Notes:}

a Contained titanium metal in rutile and ilmenite. 


\section{RUTILE}

Data

Conversion

Source

(A)

(B) $\quad 392.00 \mathrm{STx} 10^{3}$

$355.62 \operatorname{MTx}_{10}^{3} \quad$ BOM/MCS (1986)

(C) $\quad 330.00 \$ / \mathrm{ST}$

$363.76 \$ / M T \quad$ BOM/MCS (1986)

(D)

(E)

$129.58 \$ \times 10^{6}$

(A) $x(C)$

(F)

(G)

$13.40 \operatorname{sTx} 10^{6}$

13,056.48 $\operatorname{MTx} 10^{3}$

(B) $\mathrm{x}(\mathrm{C})$

( $\mathrm{H})$

$200.00 \mathrm{~s} \operatorname{Tx} 10^{6}$

$181,440.00 \operatorname{MTx} 10^{3}$

[(D) $\times 100] /(\mathrm{E})$

( I)

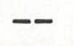

$$
7.20 \%
$$

Various $^{a}$

$(\mathrm{J})$

509.66 Years

BOM/MCS (1986)

(K)

( L)

See: Titanium

\section{Notes:}

a Sum of the following seabed resource estimates:

Atlantic \& Gulf

Mozambique
$12,156.48 *$

$\frac{900.00}{13,056.48 * *}$

* "Undiscovered marginal resources" from the Atlantic and Gulf shelves (originally from McKelvey, 1968).

** Rounded to $13,060.00 \mathrm{MTx}^{3} 0^{3}$ in Broadus (1987). 


\section{ILMENITE}

Data

Conversion

Source

(A)

(B)

$$
4,615.00 \mathrm{ST} \times 10^{3}
$$

4,186.73 $\operatorname{MTx} 10^{3}$

BOM/MCS (1986)

(C)

$44.00 \$ / \mathrm{LT}$

$48.50 \quad \$ / \mathrm{MT}$

BOM/MCS (1986)

(D)

$$
\begin{array}{lll} 
& & (\mathrm{A}) \times(\mathrm{C}) \\
205.16 & \$ \times 10^{6} & (\mathrm{~B}) \times(\mathrm{C}) \\
& & {[(\mathrm{D}) \times 100] /(} \\
536.78 & \mathrm{MTx} 10^{3} & \text { Various }^{\mathrm{a}} \\
200.00 & \mathrm{MTx} 10^{3} & \text { BOM/MCS }(1986 \\
25.41 \% & {[(\mathrm{G}) \times 100] / \mathrm{H}} \\
217.00 \text { Years } & \text { (H)/(B) }
\end{array}
$$

$\begin{array}{lll}230,536.78 & \operatorname{MTx}_{10} 0^{3} & \text { Various }^{\mathrm{a}} \\ 907,200.00 & \operatorname{MTx} 10^{3} & \text { BOM/MCS (1986) }\end{array}$

(I)

(K)

(L)

See: Titanium

\section{Notes:}

a Sum of the following seabed resource estimates:

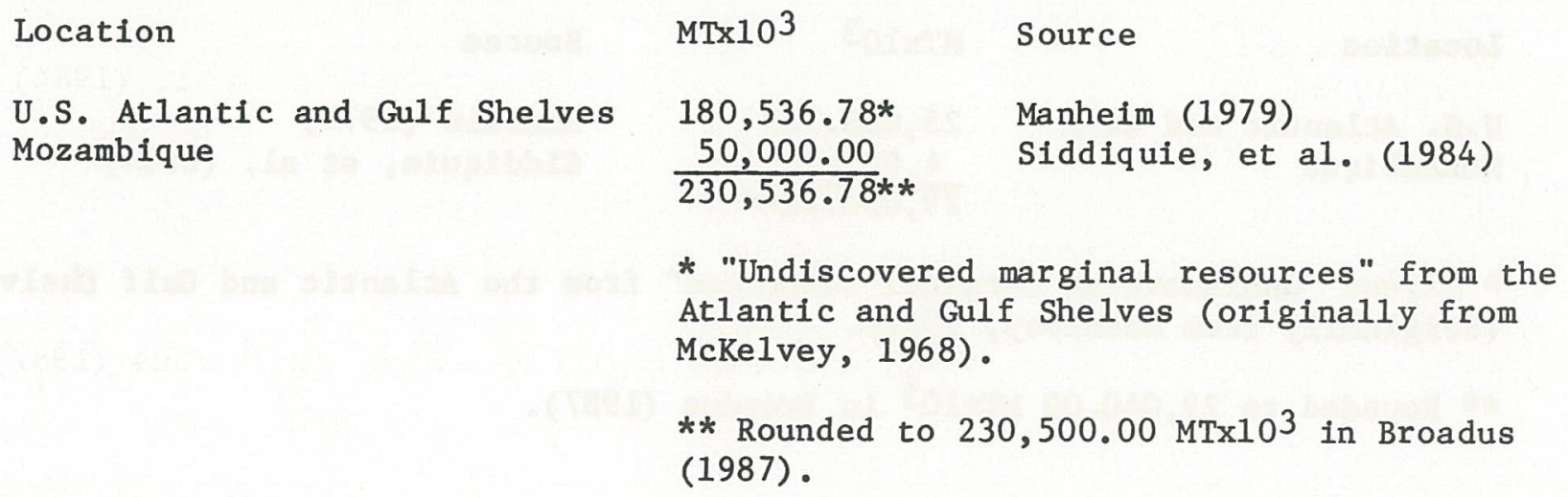


ZIRCONIUM

Data

\section{(A)}

(B)

(C)

(D)

(E)

(F)

(G)

(H)

(I)

( $\mathrm{J})$

(K)

(L)
Conversion

Source
BOM/MCS (1986)

BOM/MCS (1986)

(A) $x(C)$

(B) $x(C)$

[(D) $\times 100] /(E)$

$29,038.72 \mathrm{MT} / 10^{3} \quad$ Various ${ }^{\mathrm{a}}$

$54,432.00 \mathrm{MTx} \times 10^{3} \quad$ BOM/MCS (1986)

$53.35 \% \quad[(G) \times 100] / H$

77.77 Years

(H) /(B)

Notes:

a Sum of the following seabed resource estimates:

\begin{tabular}{lll} 
Location & \multicolumn{1}{c}{${\operatorname{MTx} 10^{3}}$} & Source \\
U.S. Atlantic and Gulf & $25,038.72^{\star}$ & Manheim (1979) \\
Mozambique & $\frac{4,000.00}{29,038.72^{\star *}}$ & Siddiquie, et a1. (1984)
\end{tabular}

* Zircon "undiscovered marginal resources" from the Atlantic and Gulf Shelves (originally from McKelvey, 1968).

** Rounded to $29,040.00 \mathrm{MTx} 10^{3}$ in Broadus (1987). 


\section{HAFNIUM}

Data

Conversion

Source

(A)

(B)

$$
80.00 \mathrm{ST}
$$

$0.07 \operatorname{MTx}^{3} 0^{3}$

BOM/MCS (1986)

(C) $\quad 105.00 \$ / L B$

$231,483.00 \quad \$ / \mathrm{MT}$

BOM/MCS $(1986)^{a}$

(D)

$\begin{array}{clll} & & (\mathrm{A}) \times(\mathrm{C}) \\ 16.89 & \$ \times 10^{6} & (\mathrm{~B}) \times(\mathrm{C}) \\ & & {[(\mathrm{D}) \times 100] /(\mathrm{E})} \\ 290.39 & \mathrm{MTx} 10^{3} & \text { See: Zirconium } \\ 544.32 & \mathrm{MTx}^{\mathrm{b}} 0^{3} & \text { See: Zirconium } \\ 53.35 & \% & {[(\mathrm{G}) \times 100] / \mathrm{H}^{b}} \\ 7,452.05 & \text { Years } & \text { (H)/(B) }\end{array}$

(K)

(L)

Notes:

a Average of reported extreme sponge price values.

b Hafnium resources estimated at one-hundredth the size of zirconium resources. 


\section{YTTRIUM}

Data

Conversion

Source

(A)

(B) $\quad 400.00 \mathrm{MT}$

$0.40 \operatorname{MTx}_{10} 3$ Hedrick, p.c. $(1986)^{a}$

(C) $35.02 \$ / K G$

$35,020.00 \$ / M T \quad$ BOM/MCS (1986)

(D)

(A) $\mathrm{x}(\mathrm{C})$

(E)

$14.01 \$ \times 10^{6}$

(B) $x(C)$

(F)

[(D) $\times 100] /(E)$

(G)

$3.80 \operatorname{MTx} 10^{6}$

3,447.36 MTx $10^{3}$ Manheim (1979) $\mathrm{b}$

(H) $190,000.00 \mathrm{ST}$

$172.37 \mathrm{MTx}_{10} 3 \quad$ BOM/MFP (1980)

(I)

[(G) $\times 100] / H$

(J)

430.00 Years

(H) $/(\mathrm{B})$

(K)

(L)

Notes:

a Contained yttrium oxide in monazite concentrates. *

b Monazite (a source of yttrium, thorium, and rare earths) "undiscovered marginal resources" from the Atlantic and Gulf shelves (originally from McKelvey, 1968), rounded to $3,450.00 \mathrm{MTx}^{3}{ }^{3}$. This same figure also is used for thorium.

* James B. Hedrick, Mineral commodity Specialist, U.S. Bureau of Mines, Personal communication. 
THORI UM

$\underline{\text { Data }}$

Conversion

Source

(A)

(B) $\quad 1,544.00 \mathrm{MT}$

1. $54 \mathrm{MT} \times 10^{3}$

BOM/MFP (1985)a

(C) $35.85 \$ / \mathrm{KG}$

$35,850.00 \$ / \mathrm{MT}$

BOM/MCS (1986)

(D)

(A) $x(C)$

(E)

$-$

$71.70 \$ \times 10^{6}$

(B) $x(C)$

(F)

(G)

3. $8 \operatorname{MT} \times 10^{6}$

$3,447.36 \mathrm{MT} \times 10^{3}$

[(D) $\times 100] /(E)$

(H) $\quad 5,697.00 \mathrm{ST} \times 10^{3}$

$5,168.32 \mathrm{MT} \times 10^{3}$

Manheim (1979)c

(I)

BOM/MFP (1980)

(J)

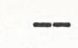

$2,584.00$ Years

$[(G) \times 100] / H$

(K)

(L) $\quad 140.00 \mathrm{MT} \times 10^{12}$

$140.00 \operatorname{MTx} 10^{12}$

Erickson (1973)

\section{Notes:}

a 1983 world production.

b Thorium oxide, $99 \%$ grade.

c Monazite (a source of yttrium, thorium, and rare earths) "undiscovered marginal resources" from the Atlantic and Gulf shelves (originally from McKelvey, 1968), rounded to $3,450.00 \mathrm{MTx}^{3} 0^{3}$. This same figure also is used for yttrium. 


\section{CHROMITE}

Data

(A)

(B)

(C)

$10,600.00 \quad \operatorname{sTx} 10^{3}$

$42.00 \$ / \mathrm{MT}$

(D)

(E)

(F)

(G)

(H)

(I)

( J )

(K)

( L)
Conversion

$$
9,616.32 \operatorname{MTx} 10^{3}
$$

$42.00 \$ / \mathrm{MT}$

$$
\begin{array}{rll}
403.87 & \$ \times 10^{6} & (\mathrm{~B}) \times(\mathrm{C}) \\
& & {[(\mathrm{D}) \times 100] /(\mathrm{E})} \\
34,658.00 & {\mathrm{MTx} 10^{3}} & \text { Various }^{\mathrm{b}} \\
32,659,200.00 & \mathrm{MTx} 10^{3} & \text { B OM/MFP (1980) } \\
0.11 & \% & {[(\mathrm{G}) \times 100] / \mathrm{H}} \\
3,396.34 & \text { Years } & (\mathrm{H}) /(\mathrm{B}) \\
1.36 & \% & \text { Leontief }(1984) / \\
2,600.00 & \text { MTx10 } 12 & \text { Erickson (1973) }
\end{array}
$$

Notes:

a South African chromite ore.

b Sum of the following resource extimates:

Location

Oregon

Lae, Marobe Coast, Papua New Guinea

Southwest Oregon Beach Sands

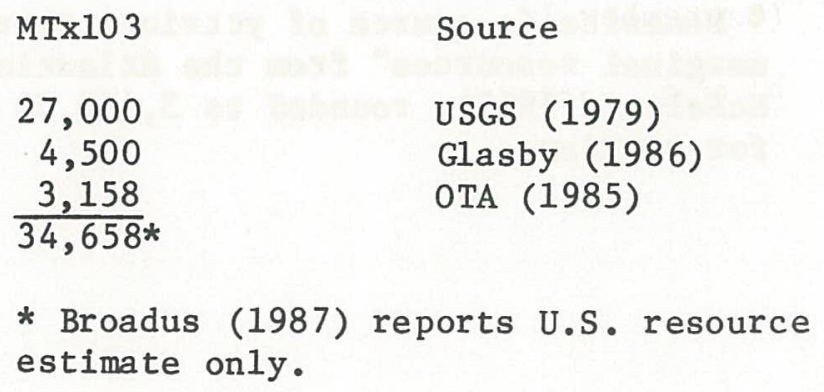


$\underline{\text { GOLD }}$

Data
(A)
$30.00 \operatorname{TROZ\times 10^{3}}$
(B)
47.00 TROZ $\times 10^{6}$
(C)
(D)
(E)
(F)
(G)
(H)
(I)
(J)
(K)
(L)

\section{Conversion}

$0.90 \mathrm{MT}$

$1.41 \mathrm{MTx} 10^{3}$

$10,600,000.00 \quad \$ / M T$

$9.54 \$ \times 10^{6}$

$10,600.00 \$ \times 10^{6}$

$0.09 \%$

$0.87 \operatorname{MTx} 10^{3}$

$72.00 \operatorname{MTx} 10^{3}$

$0.28 \%$

72.00 Years

$443.06 \%$

$0.08 \operatorname{MTx}^{12}$
Source

CCT (1987)aㅢ

BOM/MCS (1986)

BOM/MCS (1986)

(A) $x(C)$

(B) $x(C)$

[(D) $\times 100] /(E)$

USGS (1979) $\underline{\mathrm{b}} /$

BOM/MCS (1986)

$[(G) \times 100] / H$

(H) / (B)

Leontief et al. (1984)

Erickson (1973)

Notes: (also see: Silver notes)

a/ "Barge Sifts 30,000 Ounces of Gold in Waters Off Nome," Cape Cod Times (September 19, 1987).

b/ U.S. estimates for:

Location

Gulf of Alaska, Alaska

Bering \& Chukchi Seas, Alaska

Columbia River \& Coos Bay, Oregon
TROZ $\times 10^{6}$

10.00

$13.00 *$

$\frac{6.00}{29.00}$

* ("Between 5 and 20 TROZx106) 
SILVER $^{a}$

Data

(A)

(B)

(C)

(D)

(E)

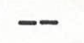

(F)

(G)

(H) $\quad 24,755.00 \quad$ TROZ $\times 10^{6}$

(I)

(J)

(K) $\quad 2,190.00 \quad \operatorname{MTx} 10^{3}$

(L) $\quad 1.80 \quad \operatorname{MTx} 10^{12}$
Conversion

Source

$\begin{array}{rlr}11.82 & \mathrm{MTx}^{3} 0^{3} & \text { BOM/MCS }(1986) \\ 206,666.67 & \$ / \mathrm{MT} & \text { BOM/MCS }(1986)\end{array}$

$$
2,480.00 \quad \$ \times 10^{6} \quad \text { (B) } x(C)
$$

$742.65 \operatorname{MTx}^{3} \quad$ Bом/MFP (1980)

$\begin{array}{rll}61.92 & \text { Years } & (\mathrm{H}) /(\mathrm{B}) \\ 294.75 \% & \text { Leontief et a1. (1984) } \\ 1.80 & \text { MTx10 }^{12} & \text { Erickson (1973) }\end{array}$

Notes:

a Bolton et al. (1986) report the occurrence of silver and gold in ferromanganese crusts from a back-arc setting in the soutwest Pacific near Australia and New Zealand. 
PLATINUM

Data Conversion Source

(A)

(B) $\quad 7,400.00 \mathrm{TROZ} \times 10^{3}$

$\begin{array}{rlr}0.22 & \mathrm{MTx} 10^{3} & \text { BOM/MCS (1986) } \\ 9,000,000.00 & \$ / \mathrm{MT} & \text { BOM/MCS (1986) }\end{array}$

(C)

270.00 \$/TROZ

$9,000,000.00 \quad \$ / M T$

(D)

(E)

$$
1,998.00 \quad \$ \times 10^{6} \quad \text { (B) } \times(C)
$$

(F)

$0.35 \operatorname{TROZ} \times 10^{6}$

$$
0.01 \operatorname{MTx}^{3} \quad \text { USGS }(1979)^{\mathrm{a}}
$$

$3.30 \mathrm{TROZ} \times 10^{9}$

$99.00 \mathrm{MT} \times 10^{3}$

BOM/MCS (1986)

(I)

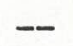

(J)

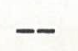

$$
0.01 \%
$$$$
\text { ; (G) } \times 100=/ \mathrm{H}
$$

(K) $12,400.00$ MT

$$
445.95 \text { Years }
$$

$(\mathrm{H}) /(\mathrm{B})$

(L) $\quad 1.10 \operatorname{MTx} 10^{12}$

$12.53 \%$

Leontief et al. (1984)

1.10 $\operatorname{MTx} 10^{12} \quad$ Erickson (1973)

Notes:

a U.S. estimate only of "identified resources" off Columbia River and Coos Bay, Oregon. Not included are recent estimates of platinum in "cobalt crust" deposits located in the EEZs of U.S. Trust and Affiliated Territories or of manganese nodules located between the Clarion and Clipperton fracture zones:

\begin{tabular}{lcrl} 
Mineral & TROZ $\times 10^{6}$ & \multicolumn{1}{c}{$\mathrm{MT}^{2} 10^{3}$} & Source \\
Crusts & 78.15 & 2.34 & Clark et a1. (1985) \\
Nodules & -- & $\frac{0.40-1.50}{2.74-3.84}$ & Manheim (1986)
\end{tabular}

Halbach (1984) reports platinum enrichment in crusts from the central Pacific region. The U.S. Bureau of Mines has been involved in a resource assessment of platinum-group-metal (PGM) placers south of Goodnews Bay, Alaska (James C. Barker, 1986, Presentation at 17th Annual Underwater Mining Institute, Biloxi, Mississippi, November 3 ). 


\section{DIAMOND}

(note changes in measures)

$\underline{\text { Data }}$

(A) $100,000.00 \quad \mathrm{CT}$

(B) $\quad 20,837.00 \quad \operatorname{CTx} 10^{3}$

(C) $\quad 285.35 \$ / C T$

(D)

(E) $5,945.80 \quad \$ \times 10^{6}$

(F)

(G)

(H) $\quad 250.00 \quad \operatorname{CT} \times 10^{6}$

(I)

(J) $\quad 11.99$

(K)

(L)
Conversion

\begin{tabular}{|c|c|c|}
\hline 0.02 & MT & Bartlett (1986) a \\
\hline 4.17 & MT & BOM/MFP (1985) \\
\hline $1,426,800,000.00$ & $\$ / \mathrm{MT}$ & $\mathrm{BOM} / \mathrm{MFP}$ (1985)므 \\
\hline $28,520.00$ & $\$ \times 10^{3}$ & (A) $x(C)$ \\
\hline $5,945.80$ & $\$ \times 10^{6}$ & (B) $x(C)$ \\
\hline 0.48 & $\%$ & {$[(D) \times 100] /(E)$} \\
\hline
\end{tabular}

$50.00 \mathrm{MT}$

$\mathrm{BOM} / \mathrm{MFP}$ (1985)듸

Notes:

11.99 Years (H)/(B)

a/ South African "alluvial" and marine production reported by Bartlett (1986). Hale and McLaren (1984) reported 50,700.00 CT of gem-quality diamonds recovered off Namibia in 1979-80. Lampietie (unpublished, Oceans '86 conference meeting on marine minerals) reports artisanal diamond mining occurring off Namibia at present.

b/ Diamond prices vary widely due to several factors. This price is the per carat 1983 rough natural diamond declared value for consumption in the United States.

c/ World gem diamond "reserve." 
COBALT

Data

(A)

(B) $35,100.00 \mathrm{sT}$

(C) $\quad 11.50 \$ / \mathrm{LB}$

(D)

(E)

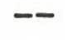

(F)

(G)

(H)

(I)

(J)

$6.40-24.00 \quad \operatorname{MTx} 10^{6}$

$12.00 \quad \operatorname{STx} 10^{6}$

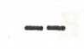

(K)

(L) $\quad 600.00 \quad \operatorname{MTx} 10^{12}$
Conversion

$$
\begin{array}{rlr}
31.84 & \text { MTx10 }^{3} & \text { BOM/MCS (1986) } \\
25,352.90 & \text { \$/MT } & \text { BOM/MCS (1986) }
\end{array}
$$

\begin{tabular}{|c|c|c|}
\hline 811.30 & $\$ \times 10^{6}$ & (B) $x(C)$ \\
\hline $6-24,000.00$ & $\operatorname{MT} \times 10^{3}$ & Manheim (1986)ㅡㅡ \\
\hline $10,886.00$ & $\operatorname{MTx} 10^{3}$ & BOM/MCS (1986) \\
\hline $55.12-220.47$ & $\%$ & {$[(G) \times 100] / H$} \\
\hline 340.19 & Years & $(\mathrm{H}) /(\mathrm{B})$ \\
\hline 600.00 & $\operatorname{MTx} 10^{12}$ & Erickson (1973) \\
\hline
\end{tabular}

$811.30 \$ \times 10^{6}$

(B) $x(C)$

Source

Notes:

a/ Estimate for manganese nodules located between Clarion and Clipperton fracture zones. Does not include the following other estimates: $39,780.00$ MTx $10^{3}$ for cobalt in "crust" deposits located in the EEZs of U.S. Trust and Affiliated Territories (Clark et al., 1985); $2,487.00 \mathrm{MTx}^{3}{ }^{3}$ for cobalt in "crust" deposits located in the EEZ of Hawaii (Hawaii and MMS, 1987); cobalt "world resources" in seabed nodules of 226,800.00 MTx10 ${ }^{3}$ (BOM/MFP, 1980); cobalt "proven reserves" in Red Sea muds at the Atlantis II Deep of 5.23 MTx10 3 (Mustafa et al., 1984). 
NICKEL

Data

(A)

(B) $821,000.00 \mathrm{sT}$

(C)

$2.28 \$ / L B$

Conversion

(F)

(G) $\quad 35-131.00 \quad \operatorname{MT} \times 10^{6}$

(H) $\quad 143.00 \quad \mathrm{STx} 10^{6}$

( J )

(K) $99,590.00 \quad \operatorname{MTx} 10^{3}$

(L) $\quad 2.13 \quad \mathrm{MTx}_{10} 0^{12}$

$$
744.81 \operatorname{MTx} 10^{3}
$$$$
5,026.49 \$ / M T
$$

$$
3,744.37 \$ \times 10^{6}
$$

(B) $x(C)$

Source

BOM/MCS (1986)

BOM/MCS (1986)

$$
\begin{aligned}
& \text { 35-131,000.00 MTx10 }{ }^{3} \quad \text { Manheim (1986)는 } \\
& 129,730.00 \mathrm{MTx}_{10}^{3} \mathrm{BOM} / \mathrm{MCS} \text { (1986) } \\
& 26.98-100.98 \% \quad[(G) \times 100] / H \\
& 174.13 \text { Years } \quad(\mathrm{H}) /(\mathrm{B}) \\
& 76.77 \% \text { Leontief et al. (1984) } \\
& 2.13 \operatorname{MTx} 10^{12} \text { Erickson (1973) }
\end{aligned}
$$

Notes:

a/ Estimate for manganese nodules located between Clarion and Clipperton fracture zones. Does not include the following other estimates: 21,380.00 MTx $10^{3}$ for nickel in "crust" deposits located in the EEZs of U.S. Trust and Affiliated Territories (Clark et al., 1985); 1,304.00 $\mathrm{MTx}^{3}{ }^{3}$ for nickel in "crust" deposits located in the EEZ of Hawaii (Hawaii and MMS, 1987); nickel "world resources" in seabed nodules of $689,472.00 \mathrm{MTx} 10^{3}$ (BOM/MFP, 1980). 
MANGANESE

$\underline{\text { Data }}$

(A)

(B) $\quad 25,800.00 \quad \mathrm{ST} \times 10^{3}$

(C)

$1.43 \$ / \mathrm{LTU}$

(D)

(E)

(F)

(G)

$706.00-$

$2,600.00 \mathrm{MT} \times 10^{6}$

(H) $12,000,000.00 \mathrm{sT} \times 10^{3}$

(I)

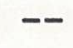

(J)

(K) $1,810,000.00 \quad \operatorname{MTx} 10^{3}$

(L)

$31.20 \operatorname{MTx} 10^{15}$
Conversion

$$
\begin{array}{rlr}
23,405.76 & \operatorname{MTx}_{10} 0^{3} & \text { BOM/MCS }(1986) \\
140.74 & \$ / M T & \text { BOM/MCS }(1986)^{a}
\end{array}
$$

\begin{tabular}{|c|c|c|}
\hline $\begin{array}{r}706,000.00- \\
2,600,000.00\end{array}$ & $\operatorname{MTx} 10^{3}$ & Manheim $(1986)^{b}$ \\
\hline $10,886,400.00$ & $\operatorname{MT} \times 10^{3}$ & BOM/MCS (1986) \\
\hline $6.49-23.80$ & $\%$ & {$[(G) \times 100] / H$} \\
\hline 465.11 & Years & $(\mathrm{H}) /(\mathrm{B})$ \\
\hline 16.63 & $\%$ & Leontief et al. (1984) \\
\hline $31,200.00$ & $\operatorname{MTx} 10^{12}$ & Erickson (1973) \\
\hline
\end{tabular}

$$
3,300.25 \$ \times 10^{6} \quad \text { (B) } x(C)
$$

\section{Notes:}

a Manganese ore (46-48\% Mn) price expressed in long ton units, or one-hundredth of a long ton.

b Estimate for manganese nodules located between Clarion and Clipperton fracture zones. Does not include the following other estimates: 1,084, 100.00 $\mathrm{MTX}^{3}{ }^{3}$ for manganese in "crust" deposits located in the EEZs of U.S. Trust and Affiliated Territories (Clark et al., 1985); 44,651.00 $\mathrm{MTx}^{3}{ }^{3}$ for manganese in "crust" deposits located in the EEZ of Hawaii (Hawaii and MMS, 1987); manganese "world resources" in seabed nodules of $16,329,600.00 \mathrm{MTx} 10^{3}$ (BOM/MFP, 1980). 


\section{COPPER}

Data

Conversion

Source

(A)

(B) $\quad 7,805.00 \mathrm{MT} \times 10^{3}$

7, $805.00 \mathrm{MT} \times 10^{3}$

BOM/MCS (1986)

(C)

$66.90 \mathrm{c} / \mathrm{LB}$

$1,474.88$ \$/MT

BOM/MCS (1986)

(D)

(E)

$11,512.38 \$ \times 10^{6}$

(B) $\mathrm{x}(\mathrm{C})$

(F)

(G) $33-314,200.00 \mathrm{MTx} 10^{3}$

$33-314,200.00 \mathrm{MT} \times 10^{3}$

Various $^{a}$

(H)

$1.60 \mathrm{Mtx} 10^{9}$

$1,600,000.00 \mathrm{MT} \times 10^{3}$

BOM/MCS (1986)

(I)

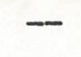

$2.07-19.64 \%$

[(G) $\times 100] / H$

(J)

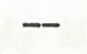

205.00 Years

(H) $/(B)$

(K) $\quad 1,383.00 \mathrm{MT} \times 10^{6}$

$86.44 \%$

Leontief et al. (1984)

(L) $\quad 1,510.00 \mathrm{MT} \times 1012$

1,510.00 MTx1012 Erickson (1973)

\section{Notes:}

a Seabed copper resources are estimated as follows:

\begin{tabular}{lc} 
Location & \multicolumn{1}{c|}{ MTx103 } \\
Clarion-Clipperton Zone Nodules & $29-108,000 *$ \\
World Marine Polymetallic Sulfides & $4-215,600$ \\
Red Sea Metalliferous Muds & $\frac{600}{33-314,000}$
\end{tabular}

*Copper "world resources" in seabed nodules have also been estimated at $700,000.00 \mathrm{MT} \times 10^{3}$ (BOM/MFP, 1980). 
ZINC

$\underline{\text { Data }}$

$\underline{\text { Conversion } \quad \underline{\text { Source }}}$

(A)

(B) $\quad 6,560.00 \mathrm{MTx} 10^{3}$

$6,560.00 \mathrm{MTx} 10^{3}$ BOM/MCS (1986)

(C)

$40.50 \mathrm{c} / \mathrm{LB}$

$892.86 \$ / M T$

BOM/MCS (1986)

(D)

(E)

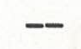

$5,858.08 \$ \times 10^{6}$

(B) $x(C)$

(F)

(G) $10.74-518.04 \mathrm{MT} \times 10^{6}$

$$
\begin{aligned}
10,740-518,040.00 \mathrm{MT}_{1} 10^{3} & \text { Various } \\
1,800,000.00 \mathrm{MTx} 10^{3} & \text { BOM/MCS (1986) }
\end{aligned}
$$

(H)

$1.80 \operatorname{MTx} 10^{9}$

(I)

$$
0.60-28.78 \% \quad[(G) \times 100] / H
$$

( J )

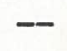

274.39 Years

(H) $/(\mathrm{B})$

(K) $\quad 848.00 \mathrm{MT} \times 10^{6}$

$47.11 \%$

Leontief et a1. (1984)

(L) $\quad 2,250.00 \mathrm{MT} \times 10^{12}$

$2,250.00 \mathrm{MT} \times 10^{12}$

Erickson (1973)

\begin{tabular}{|c|c|c|}
\hline Location & MTx 103 & Source \\
\hline $\begin{array}{l}\text { World Marine Polymetallic Sulfides } \\
\text { Red Sea Metalliferous Muds }\end{array}$ & $\begin{array}{r}8,300-515,600 \\
2,440 *\end{array}$ & $\begin{array}{l}\text { Broadus (1984) } \\
\text { Mustafa et al. (1984) }\end{array}$ \\
\hline
\end{tabular}

\section{Notes:}

a Seabed zinc resources have been estimated as follows:

*("Proven reserves" of zinc.) 
LEAD

Data

Conversion

Source

(A)

(B) $\quad 3,350.00 \mathrm{MTx} 10^{3}$

$3,350.00 \mathrm{MT} \times 10^{3}$

BOM/MCS (1986)

(C)

$19.00 \mathrm{c} / \mathrm{LB}$

$418.87 \$ / \mathrm{MT}$

BOM/MCS (1986)

(D)

(E)

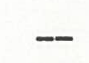

$1,403.65 \$ \times 10^{6}$

(B) $x(C)$

(F)

(G)

(H)

$$
\begin{aligned}
& \text { (Possible occ } \\
& 1.40 \mathrm{MTx} 10^{9}
\end{aligned}
$$

in marine polymetallic sulfides?)

(I)

(J)

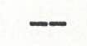

(K) $\quad 639.00 \mathrm{MT} \times 10^{6}$

$1,400,000.00 \mathrm{MT} \times 10^{3}$

BOM/MCS (1986)

(L) $\quad 290.00 \mathrm{MT} \times 10^{12}$

417.91 Years
$45.64 \%$
$290.00 \mathrm{MT} \times 10^{12}$

(H) $/(\mathrm{B})$

Leontief et al. (1984)

Erickson (1973)

Notes: 
Section III: Price Series

Data on the estimated average prices of several material commodities are tabulated here. The primary references are Manthy (1978), following Potter and Christy (1962), and the U.S. Bureau of Mines (1985, 1980). Other specific sources are named in the tables. Wherever possible, data used by Manthy are updated using the same reference materials that he employed. Because the data for these price series are derived from a number of different sources, it has not been possible to obtain series of identical length. The prices are deflated with the consumer price index (CPI) published by the U.S. Bureau of the Census (1985, 1976) (see Table III-1). Deflated prices are indexed to 1967 as a base year $(1967=100)$. The figures appearing in these tables have been rounded for presentation. In several cases, following Slade (1982b), linear (solid line) and quadratic (dashed line) fits are shown. These plotted series and fits appeared in Broadus (1987). The deflating, indexing, and curve fitting for these price series was conducted by Andy Solow, Marine Policy Center, WHOI. The fits are not necessarily reliable indicators of price trends over time and have been constructed only as a general guide to inspection of the time series.

Composite price series were constructed for sand and gravel, manganese nodules, cobalt crusts, and marine polymetallic sulfides. These composites are grade-weighted prices, using an average weight percent estimated for specific material commodities found in these seabed deposits. The U.S. Bureau of Mines estimated average price for sand and gravel was used without modification. The following weight percents were used for nodules (Haynes and Law, 1982; Manheim, 1986):

$\begin{array}{lc}\text { Cobalt } & 0.24 \% \\ \text { Nickel } & 1.28 \\ \text { Manganese } & 25.40 \\ \text { Copper } & 1.02\end{array}$

The following weight percents were used for cobalt crusts (Manheim, 1986):

$\begin{array}{lc}\text { Cobalt } & 0.73 \% \\ \text { Nickel } & 0.47 \\ \text { Manganese } & 23.06\end{array}$

The following weight percents were used for marine polymetallic sulfides from the $21^{\circ} \mathrm{N}$ East Pacific Rise deposits (Bischoff et al., 1983):
Zinc
$32.30 \%$
Copper
0.81 
Table III-1: CONSUMER PRICE INDEX $(1967=100)$

Source: BOC/Hist. Stat. (1976), pp. 210-211

\begin{tabular}{|c|c|c|c|c|c|}
\hline Year & Index & Year & Index & Year & Index \\
\hline 1870 & 38.0 & $\overline{1916}$ & $\overline{32.7}$ & $\overline{1962}$ & $\overline{90.6}$ \\
\hline 1871 & 36.0 & 1917 & 38.4 & 1963 & 91.7 \\
\hline 1872 & 36.0 & 1918 & 45.1 & 1964 & 92.9 \\
\hline 1873 & 36.0 & 1919 & 51.8 & 1965 & 94.5 \\
\hline 1874 & 34.0 & 1920 & 60.0 & 1966 & 97.2 \\
\hline 1875 & 33.0 & 1921 & 53.6 & 1967 & 100.0 \\
\hline 1876 & 32.0 & 1922 & 50.2 & 1968 & 104.2 \\
\hline 1877 & 32.0 & 1923 & 51.1 & 1969 & 109.8 \\
\hline 1878 & 29.0 & 1924 & 51.2 & 1970 & 116.3 \\
\hline 1879 & 28.0 & 1925 & 52.5 & 1971 & $121.3 *$ \\
\hline 1880 & 29.0 & 1926 & 53.0 & 1972 & 125.3 \\
\hline 1881 & 29.0 & 1927 & 52.0 & 1973 & 133.1 \\
\hline 1882 & 29.0 & 1928 & 51.3 & 1974 & 147.7 \\
\hline 1883 & 28.0 & 1929 & 51.3 & 1975 & 161.2 \\
\hline 1884 & 27.0 & 1930 & 50.0 & 1976 & 170.5 \\
\hline 1885 & 27.0 & 1931 & 45.6 & 1977 & 181.5 \\
\hline $\begin{array}{l}1886 \\
1887\end{array}$ & $\begin{array}{l}27.0 \\
27.0\end{array}$ & $\begin{array}{l}1932 \\
1933\end{array}$ & $\begin{array}{l}40.9 \\
38.8\end{array}$ & $\begin{array}{l}1978 \\
1979\end{array}$ & $\begin{array}{l}195.4 \\
217.4\end{array}$ \\
\hline 1888 & 27.0 & 1934 & 40.1 & 1980 & 246.8 \\
\hline 1889 & 27.0 & 1935 & 41.1 & 1981 & 272.4 \\
\hline 1890 & 27.0 & 1936 & 41.5 & 1982 & 289.1 \\
\hline 1891 & 27.0 & 1937 & 43.0 & 1983 & 298.4 \\
\hline 1892 & 27.0 & 1938 & 42.2 & 1984 & 310.7 \\
\hline 1893 & 27.0 & 1939 & 41.6 & & \\
\hline 1894 & 26.0 & 1940 & 42.0 & & \\
\hline 1895 & 25.0 & 1941 & 44.1 & & \\
\hline 1896 & 25.0 & 1942 & 48.8 & & \\
\hline 1897 & 25.0 & 1943 & 51.8 & & \\
\hline 1898 & 25.0 & 1944 & 52.7 & & \\
\hline 1899 & 25.0 & 1945 & 53.9 & & \\
\hline 1900 & 25.0 & 1946 & 58.5 & & \\
\hline 1901 & 25.0 & 1947 & 66.9 & & \\
\hline 1902 & 26.0 & 1948 & 72.1 & & \\
\hline 1903 & 27.0 & 1949 & 71.4 & & \\
\hline 1904 & 27.0 & 1950 & 72.1 & & \\
\hline 1905 & 27.0 & 1951 & 77.8 & & \\
\hline 1906 & 27.0 & 1952 & 79.5 & & \\
\hline 1907 & 28.0 & 1953 & 80.1 & & \\
\hline 1908 & 27.0 & 1954 & 80.5 & & \\
\hline 1909 & 27.0 & 1955 & 80.2 & & \\
\hline 1910 & 28.0 & 1956 & 81.4 & & \\
\hline 1911 & 28.0 & 1957 & 84.3 & & \\
\hline 1912 & 29.0 & 1958 & 86.6 & & \\
\hline 1913 & 29.7 & 1959 & 87.3 & & \\
\hline 1914 & 30.1 & 1960 & 88.7 & & \\
\hline 1915 & 30.4 & 1961 & 89.6 & & \\
\hline
\end{tabular}

*BOC/Stat. Abst. (1985), p. 475. 
The plots and price series are arranged as follows:

Commodity

Chromite

$\operatorname{Tin}$

Titanium Meta1

Rutile

Phosphate Rock

Composites

Sand and Grave

Crusts Composite
Nodule Composite
Cobalt
Manganese
Nickel
Copper
MPS Composite

Zinc

Copper (see above)
Figure

III-1a

III-1b

III-2a

III-2b

III $-3 a$

III-3b

III-3c

III-4a

III-4b

Price Series

III-5a

III $-5 b$

III $-6 a$

III-6b

III $-7 a$

III $-7 \mathrm{~b}$

III-8

III -9

III-10

III -11

III $-12 \mathrm{a}$

III-12b

III -13 
Figure III-1a

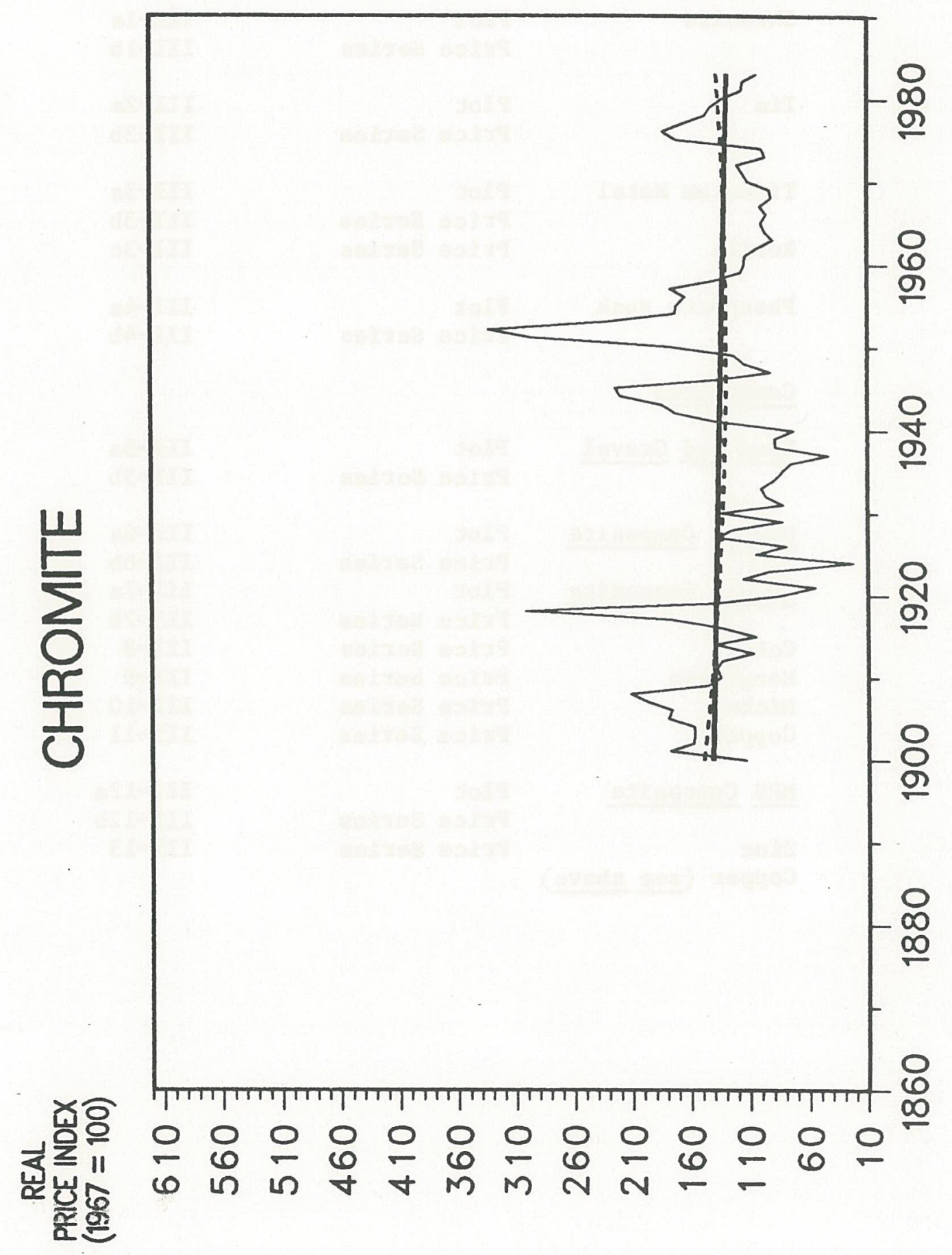


Figure III-1b

\begin{tabular}{|c|c|c|c|c|c|}
\hline Year & $\begin{array}{r}\text { Price } \\
\$ / \mathrm{ST} \\
\end{array}$ & $\begin{array}{l}\text { Def lated } \\
\text { Price }\end{array}$ & $\begin{array}{c}\text { Index } \\
(1967=100) \\
\end{array}$ & Quadratic Fit & Linear Fit \\
\hline 1900 & 10.0 & 0.40 & 113.32 & 149.34 & 141.49 \\
\hline 1901 & 15.7 & 0.63 & 177.91 & 148.54 & \\
\hline 1902 & 14.5 & 0.56 & 157.99 & 147.76 & \\
\hline 1903 & 15.0 & 0.56 & 157.39 & 146.99 & \\
\hline 1904 & 15.0 & 0.56 & 157.39 & 146.24 & \\
\hline 1905 & 17.1 & 0.63 & 179.42 & 145.51 & \\
\hline 1906 & 16.8 & 0.62 & 176.28 & 144.79 & \\
\hline 1907 & 19.5 & 0.70 & 197.30 & 144.08 & \\
\hline 1908 & 20.2 & 0.75 & 211.95 & 143.40 & \\
\hline 1909 & 13.9 & 0.51 & 145.85 & 142.73 & \\
\hline 1910 & 13.3 & 0.48 & 134.57 & 142.07 & \\
\hline 1911 & 13.6 & 0.49 & 137.60 & 141.43 & \\
\hline 1912 & 13.7 & 0.47 & 133.83 & 140.81 & \\
\hline 1913 & 11.2 & 0.38 & 106.83 & 140.20 & \\
\hline 1914 & 14.8 & 0.49 & 139.30 & 139.61 & \\
\hline 1915 & 11.2 & 0.37 & 104.37 & 139.03 & \\
\hline 1916 & 15.4 & 0.47 & 133.42 & 138.47 & \\
\hline 1917 & 24.0 & 0.63 & 177.06 & 137.93 & \\
\hline 1918 & 48.0 & 1.06 & 301.52 & 137.40 & \\
\hline 1919 & 25.5 & 0.49 & 139.46 & 136.89 & \\
\hline 1920 & 18.0 & 0.30 & 84.99 & 136.39 & \\
\hline 1921 & 10.3 & 0.19 & 54.44 & 135.91 & \\
\hline 1922 & 20.5 & 0.41 & 115.69 & 135.45 & \\
\hline 1923 & 16.8 & 0.33 & 93.14 & 135.00 & \\
\hline 1924 & 4.0 & 0.08 & 22.13 & 134.57 & \\
\hline 1925 & 19.5 & 0.37 & 105.23 & 134.15 & \\
\hline 1926 & 14.8 & 0.28 & 79.11 & 133.75 & \\
\hline 1927 & 25.2 & 0.48 & 137.29 & 133.36 & \\
\hline 1928 & 22.4 & 0.44 & 123.70 & 132.99 & \\
\hline 1929 & 14.8 & 0.29 & 81.73 & 132.64 & \\
\hline 1930 & 23.8 & 0.48 & 134.85 & 132.30 & \\
\hline 1931 & 13.1 & 0.29 & 81.39 & 131.98 & \\
\hline 1932 & 13.9 & 0.34 & 96.28 & 131.68 & \\
\hline 1933 & 13.7 & 0.35 & 100.03 & 131.39 & \\
\hline 1934 & 12.6 & 0.31 & 89.02 & 131.11 & \\
\hline 1935 & 12.0 & 0.29 & 82.72 & 130.85 & \\
\hline 1936 & 11.0 & 0.27 & 75.09 & 130.61 & \\
\hline 1937 & 6.5 & 0.15 & 42.82 & 130.38 & \\
\hline 1938 & 13.2 & 0.31 & 88.62 & 130.17 & \\
\hline 1939 & 13.0 & 0.31 & 88.53 & 129.98 & \\
\hline 1940 & 10.8 & 0.26 & 72.85 & 129.80 & \\
\hline 1941 & 21.5 & 0.49 & 138.12 & 129.64 & \\
\hline 1942 & 29.7 & 0.61 & 172.42 & 129.49 & \\
\hline 1943 & 33.7 & 0.65 & 184.31 & 129.36 & \\
\hline 1944 & 41.0 & 0.78 & 220.40 & 129.24 & \\
\hline 1945 & 42.7 & 0.79 & 224.43 & 129.14 & \\
\hline 1946 & 28.7 & 0.49 & 138.99 & 129.06 & \\
\hline
\end{tabular}


Figure III-1b

CHROMITE (contd)

\begin{tabular}{|c|c|c|c|c|c|}
\hline Year & $\begin{array}{r}\text { Price } \\
\$ / \mathrm{ST} \\
\end{array}$ & $\begin{array}{l}\text { Def lated } \\
\text { Price }\end{array}$ & $\begin{array}{c}\text { Index } \\
(1967=100) \\
\end{array}$ & Quadratic Fit & Linear Fit \\
\hline 1947 & 21.6 & 0.32 & 91.47 & 128.99 & \\
\hline 1948 & 29.0 & 0.40 & 113.95 & 128.94 & \\
\hline 1949 & 31.0 & 0.43 & 123.00 & 128.90 & \\
\hline 1950 & 45.2 & 0.63 & 177.60 & 128.88 & \\
\hline 1951 & 81.1 & 1.04 & 295.32 & 128.88 & \\
\hline 1952 & 93.5 & 1.18 & 333.19 & 128.89 & \\
\hline 1953 & 65.4 & 0.82 & 231.31 & 128.92 & \\
\hline 1954 & 49.1 & 0.61 & 172.80 & 128.96 & \\
\hline 1955 & 48.6 & 0.61 & 171.68 & 129.02 & \\
\hline 1956 & 47.1 & 0.58 & 163.92 & 129.10 & \\
\hline 1957 & 52.7 & 0.63 & 177.10 & 129.18 & \\
\hline 1958 & 43.0 & 0.50 & 140.67 & 129.29 & \\
\hline 1959 & 35.9 & 0.41 & 116.50 & 129.41 & \\
\hline 1960 & 35.6 & 0.40 & 113.70 & 129.55 & \\
\hline 1961 & 35.8 & 0.40 & 113.19 & 129.70 & \\
\hline 1962 & 32.8 & 0.36 & 102.56 & 129.87 & \\
\hline 1963 & 29.0 & 0.32 & 89.59 & 130.06 & \\
\hline 1964 & 31.8 & 0.34 & 96.97 & 130.26 & \\
\hline 1965 & 33.3 & 0.35 & 99.83 & 130.48 & \\
\hline 1966 & 32.6 & 0.34 & 95.02 & 130.71 & \\
\hline 1967 & 35.3 & 0.35 & 100.00 & 130.96 & \\
\hline 1968 & 33.5 & 0.32 & 91.08 & 131.23 & \\
\hline 1969 & 35.7 & 0.33 & 92.11 & 131.51 & \\
\hline 1970 & 45.5 & 0.39 & 110.84 & 131.80 & \\
\hline 1971 & 49.3 & 0.41 & 115.14 & 132.12 & \\
\hline 1972 & 52.8 & 0.42 & 119.38 & 132.45 & \\
\hline 1973 & 45.1 & 0.34 & 95.99 & 132.79 & \\
\hline 1974 & 51.7 & 0.35 & 99.16 & 133.15 & \\
\hline 1975 & 97.0 & 0.60 & 170.47 & 133.53 & \\
\hline 1976 & 110.0 & 0.65 & 182.73 & 133.92 & \\
\hline 1977 & 106.0 & 0.58 & 165.45 & 134.33 & \\
\hline 1978 & 101.0 & 0.52 & 146.47 & 134.75 & \\
\hline 1979 & 109.0 & 0.50 & 141.93 & 135.19 & \\
\hline 1980 & 115.0 & 0.47 & 132.02 & 135.65 & \\
\hline 1981 & 111.0 & 0.41 & 115.30 & 136.12 & \\
\hline 1982 & 117.0 & 0.41 & 114.74 & 136.61 & \\
\hline 1983 & 109.0 & 0.37 & 103.40 & 137.11 & 128.09 \\
\hline
\end{tabular}


Figure III-2a

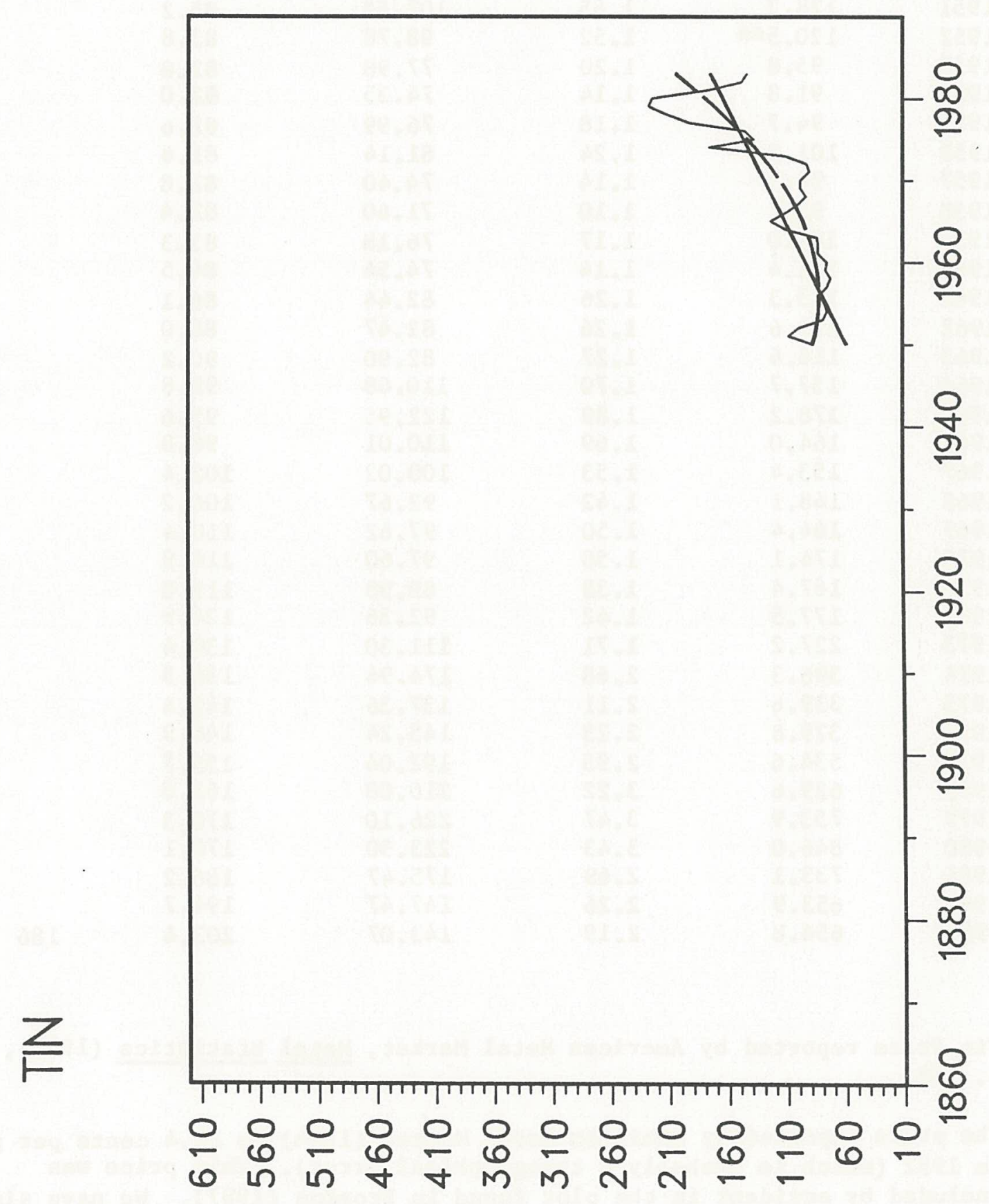


Figure III-2b

TIN

\begin{tabular}{|c|c|c|c|c|c|}
\hline Year & $\begin{array}{l}\text { Price } \\
/ 1 b^{*} \\
\end{array}$ & $\begin{array}{c}\text { Deflated } \\
\text { Price } \\
\end{array}$ & $\begin{array}{c}\text { Index } \\
(1967=100) \\
\end{array}$ & $\begin{array}{c}\text { Quadratic } \\
\text { Fit } \\
\end{array}$ & $\begin{array}{c}\text { Linear } \\
\text { Fit }\end{array}$ \\
\hline 1950 & 95.6 & 1.33 & 86.45 & 87.0 & 65 \\
\hline 1951 & 128.3 & 1.65 & 107.52 & 85.2 & \\
\hline 1952 & $120.5 * *$ & 1.52 & 98.78 & 83.8 & \\
\hline 1953 & 95.8 & 1.20 & 77.98 & 82.8 & \\
\hline 1954 & 91.8 & 1.14 & 74.35 & 82.0 & \\
\hline 1955 & 94.7 & 1.18 & 76.99 & 81.6 & \\
\hline 1956 & 101.3 & 1.24 & 81.14 & 81.6 & \\
\hline 1957 & 96.2 & 1.14 & 74.40 & 81.8 & \\
\hline 1958 & 95.1 & 1.10 & 71.60 & 82.4 & \\
\hline 1959 & 102.0 & 1.17 & 76.18 & 83.3 & \\
\hline 1960 & 101.4 & 1.14 & 74.54 & 84.5 & \\
\hline 1961 & 113.3 & 1.26 & 82.44 & 86.1 & \\
\hline 1962 & 114.6 & 1.26 & 82.47 & 88.0 & \\
\hline 1963 & 116.6 & 1.27 & 82.90 & 90.2 & \\
\hline 1964 & 157.7 & 1.70 & 110.68 & 92.8 & \\
\hline 1965 & 178.2 & 1.89 & 122.95 & 95.6 & \\
\hline 1966 & 164.0 & 1.69 & 110.01 & 98.8 & \\
\hline 1967 & 153.4 & 1.53 & 100.02 & 102.4 & \\
\hline 1968 & 148.1 & 1.42 & 92.67 & 106.2 & \\
\hline 1969 & 164.4 & 1.50 & 97.62 & 110.4 & \\
\hline 1970 & 174.1 & 1.50 & 97.60 & 114.9 & \\
\hline 1971 & 167.4 & 1.38 & 89.98 & 119.8 & \\
\hline 1972 & 177.5 & 1.42 & 92.36 & 124.9 & \\
\hline 1973 & 227.2 & 1.71 & 111.30 & 130.4 & \\
\hline 1974 & 396.3 & 2.68 & 174.94 & 136.3 & \\
\hline 1975 & 339.6 & 2.11 & 137.36 & 142.4 & \\
\hline 1976 & 379.8 & $\begin{array}{l}2.11 \\
2.23\end{array}$ & 145.24 & $\begin{array}{l}142.4 \\
148.9\end{array}$ & \\
\hline 1977 & 534.6 & 2.95 & 192.04 & 155.7 & \\
\hline 1978 & 629.6 & 3.22 & 210.08 & 162.8 & \\
\hline 1979 & 753.9 & 3.47 & 226.10 & 170.3 & \\
\hline 1980 & 846.0 & 3.43 & 223.50 & 178.1 & \\
\hline 1981 & 733.1 & 2.69 & 175.47 & 186.2 & \\
\hline 1982 & 653.9 & 2.26 & 147.47 & 194.7 & \\
\hline 1983 & 654.8 & 2.19 & 143.07 & 203.4 & 186 \\
\hline
\end{tabular}

* Tin Price reported by American Metal Market, Metal Statistics (1984), p. 198.

** The price reported by American Metal Market (1984) is 12.4 cents per pound in 1952 (which is probably a typographical error). This price was included by accident in the plot found in Broadus (1987). We nave since substituted the price found in Metallgesellschaft (1984) of 120.47 cents per pound (average) for the same year and replotted the series in Figure III-2a. 
Figure III-3a

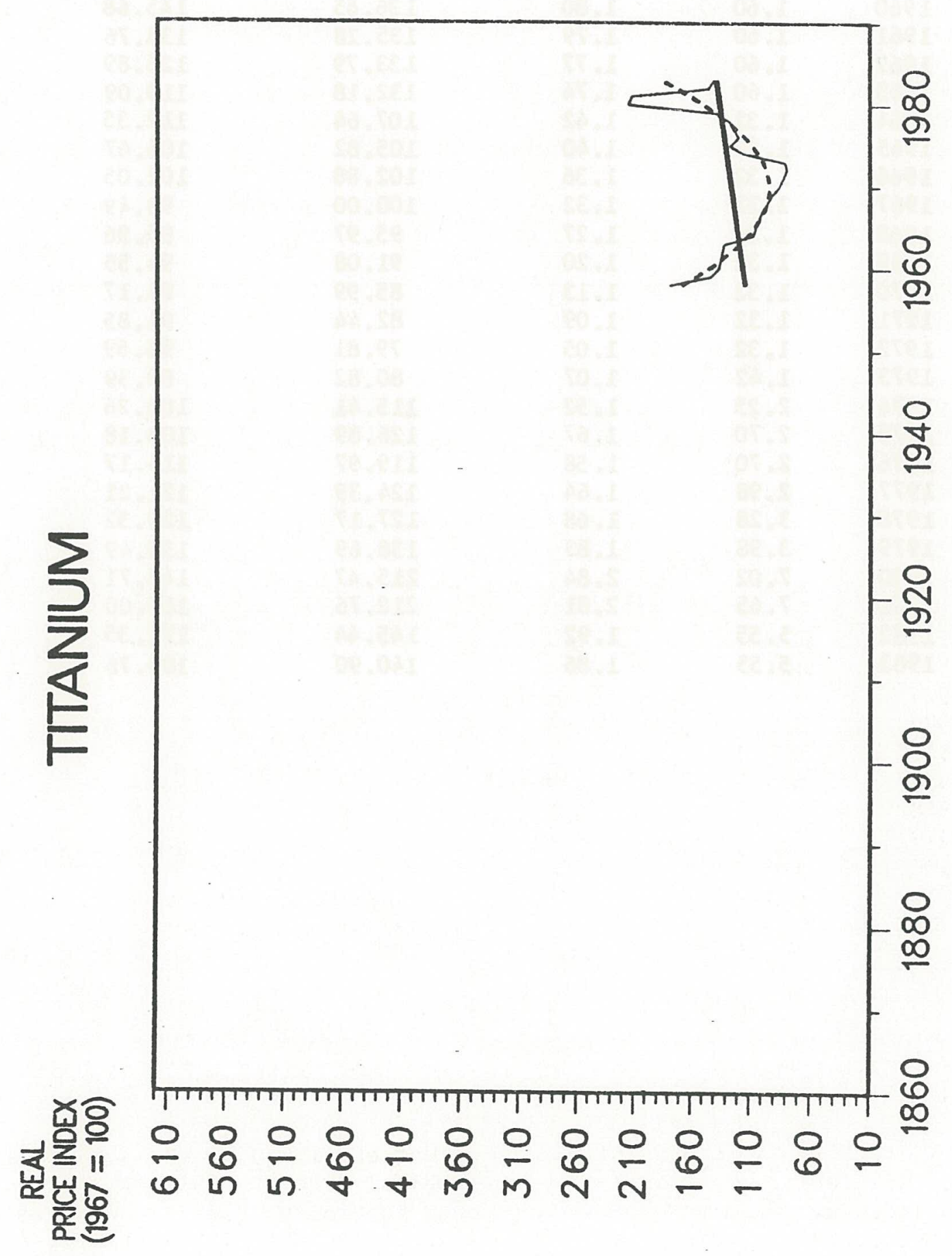


Figure III-3b

TITANIUM METAL

\begin{tabular}{|c|c|c|c|c|c|}
\hline Year & $\begin{array}{r}\text { Price } \\
\$ / 1 \mathrm{~b} \\
\end{array}$ & $\begin{array}{l}\text { Def lated Price } \\
\left(\times 10^{-2}\right) \\
\end{array}$ & $\begin{array}{c}\begin{array}{c}\text { Index } \\
(1967=100) \\
\end{array} \\
\end{array}$ & Quadratic Fit & Linear Fit \\
\hline 1958 & 2.05 & 2.37 & 179.33 & 168.71 & 114.59 \\
\hline 1959 & 1.66 & 1.90 & 144.05 & 156.67 & \\
\hline 1960 & 1.60 & 1.80 & 136.65 & 145.68 & \\
\hline 1961 & 1.60 & 1.79 & 135.28 & 135.76 & \\
\hline 1962 & 1.60 & 1.77 & 133.79 & 126.89 & \\
\hline 1963 & 1.60 & 1.74 & 132.18 & 119.09 & \\
\hline 1964 & 1. 32 & 1.42 & 107.64 & 112.35 & \\
\hline 1965 & 1.32 & 1.40 & 105.82 & 106.67 & \\
\hline 1966 & 1.32 & 1.36 & 102.88 & 102.05 & \\
\hline 1967 & 1.32 & 1.32 & 100.00 & 98.49 & \\
\hline 1968 & 1.32 & 1.27 & 95.97 & 95.96 & \\
\hline 1969 & 1.32 & 1.20 & 91.08 & 94.55 & \\
\hline 1970 & 1.32 & 1.13 & 85.99 & 94.17 & \\
\hline 1971 & 1.32 & 1.09 & 82.44 & 94.85 & \\
\hline 1972 & 1.32 & 1.05 & 79.81 & 96.59 & \\
\hline 1973 & 1.42 & 1.07 & 80.82 & 99.39 & \\
\hline 1974 & 2.25 & 1.52 & 115.41 & 103.26 & \\
\hline 1975 & 2.70 & 1.67 & 126.89 & 108.18 & \\
\hline 1976 & 2.70 & 1.58 & 119.97 & 114.17 & \\
\hline 1977 & 2.98 & 1.64 & 124.39 & 121.21 & \\
\hline 1978 & 3.28 & 1.68 & 127.17 & 129.32 & \\
\hline 1979 & 3.98 & 1.83 & 138.69 & 138.49 & \\
\hline 1980 & 7.02 & 2.84 & 215.47 & 148.71 & \\
\hline 1981 & 7.65 & 2.81 & 212.76 & 160.00 & \\
\hline 1982 & 5.55 & 1.92 & 145.44 & 172.35 & \\
\hline 1983 & 5.55 & 1.86 & 140.90 & 185.76 & 138.46 \\
\hline
\end{tabular}


Figure III- 3c

RUTILE

\begin{tabular}{|c|c|c|c|c|c|}
\hline Year & $\begin{array}{l}\text { Price } \\
\$ / 1 \mathrm{~b} \\
\end{array}$ & $\begin{array}{l}\text { Deflated Price } \\
\left(\times 10^{-3}\right) \\
\end{array}$ & $\begin{array}{c}\begin{array}{c}\text { Index } \\
(1967=100) \\
\end{array} \\
\end{array}$ & Quadratic Fit & Linear Fit \\
\hline 1958 & 0.46 & 5.31 & 115.47 & 118.57 & 110.02 \\
\hline 1959 & 0.46 & 5.27 & 114.55 & 115.59 & \\
\hline 1960 & 0.46 & 5.19 & 112.74 & 112.80 & \\
\hline 1961 & 0.46 & 5.13 & 111.61 & 110.19 & \\
\hline 1962 & 0.46 & 5.08 & 110.38 & 107.77 & \\
\hline 1963 & 0.46 & 5.02 & 109.05 & 105.54 & \\
\hline 1964 & 0.46 & 4.95 & 107.64 & 103.49 & \\
\hline 1965 & 0.46 & 4.87 & 105.82 & 101.63 & \\
\hline 1966 & 0.46 & 4.73 & 102.88 & 99.96 & \\
\hline 1967 & 0.46 & 4.60 & 100.00 & 98.48 & \\
\hline 1968 & 0.48 & 4.61 & 100.14 & 97.18 & \\
\hline 1969 & 0.48 & 4.37 & 95.03 & 96.07 & \\
\hline 1970 & 0.45 & 3.87 & 84.12 & 95.15 & \\
\hline 1971 & 0.45 & 3.71 & 80.65 & 94.41 & \\
\hline 1972 & 0.45 & 3.59 & 78.07 & 93.86 & \\
\hline 1973 & 0.50 & 3.76 & 81.66 & 93.50 & \\
\hline 1974 & 0.72 & 4.87 & 105.97 & 93.32 & \\
\hline 1975 & 0.73 & 4.53 & 98.45 & 93.33 & \\
\hline 1976 & 0.78 & 4.57 & 99.45 & 93.53 & \\
\hline 1977 & 0.81 & 4.46 & 97.02 & 93.91 & \\
\hline 1978 & 0.85 & 4.35 & 94.57 & 94.48 & \\
\hline 1979 & 0.98 & 4.51 & 98.00 & 95.24 & \\
\hline 1980 & 1.05 & 4.25 & 92.49 & 96.19 & \\
\hline 1981 & 1.25 & 4.59 & 99.76 & 97.32 & \\
\hline 1982 & 1.25 & 4.32 & 93.99 & 98.64 & \\
\hline 1983 & 1.25 & 4.19 & 91.07 & 100.15 & 88.83 \\
\hline
\end{tabular}


Figure III-4a

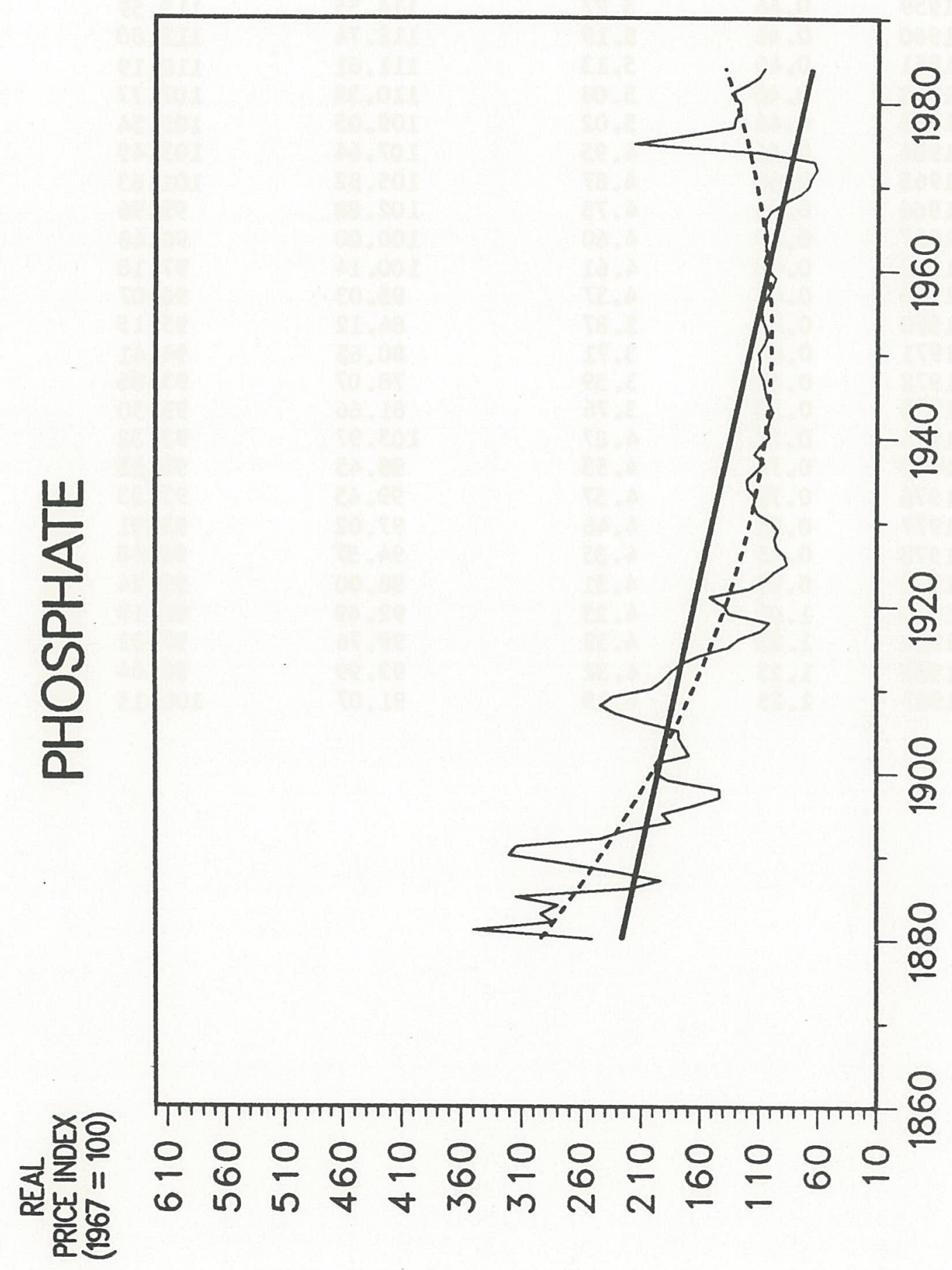


Figure III-4b

PHOSPHATE ROCK

\begin{tabular}{|c|c|c|c|c|c|}
\hline Year & $\begin{array}{l}\text { Price } \\
\$ / \mathrm{MT}\end{array}$ & $\begin{array}{l}\text { Deflated } \\
\text { Price }\end{array}$ & $\begin{array}{c}\begin{array}{c}\text { Index } \\
(1967=100) \\
\end{array} \\
\end{array}$ & Quadratic Fit & Lineax Fit \\
\hline 1880 & 5.3 & 0.18 & 250.36 & 293.20 & 225.86 \\
\hline 1881 & 7.4 & 0.26 & 349.56 & 287.83 & \\
\hline 1882 & 6.0 & 0.21 & 283.43 & 282.54 & \\
\hline 1883 & 6.0 & 0.21 & 293.55 & 277.32 & \\
\hline 1884 & 5.5 & 0.20 & 279.05 & 272.18 & \\
\hline 1885 & 6.2 & 0.23 & 314.57 & 267.12 & \\
\hline 1886 & 4.3 & 0.16 & 218.17 & 262.13 & \\
\hline 1887 & 3.8 & 0.14 & 192.80 & 257.21 & \\
\hline 1888 & 4.5 & 0.17 & 228.32 & 252.37 & \\
\hline 1889 & 5.4 & 0.20 & 273.98 & 247.61 & \\
\hline 1890 & 6.3 & 0.23 & 319.64 & 242.92 & \\
\hline 1891 & 6.2 & 0.23 & 314.57 & 238.31 & \\
\hline 1892 & 4.8 & 0.18 & 243.54 & 233.77 & \\
\hline 1893 & 4.4 & 0.16 & 223.24 & 229.31 & \\
\hline 1894 & 3.5 & 0.13 & 184.41 & 224.92 & \\
\hline 1895 & 3.5 & 0.14 & 191.79 & 220.61 & \\
\hline 1896 & 3.0 & 0.12 & 164.39 & 216.37 & \\
\hline 1897 & 2.6 & 0.10 & 142.47 & 212.21 & \\
\hline 1898 & 2.6 & 0.10 & 142.47 & 208.13 & \\
\hline 1899 & 3.4 & 0.14 & 186.31 & 204.12 & \\
\hline 1900 & 3.6 & 0.14 & 197.27 & 200.18 & \\
\hline 1901 & 3.6 & 0.14 & 197.27 & 196.32 & \\
\hline 1902 & 3.2 & 0.12 & 168.60 & 192.54 & \\
\hline 1903 & 3.4 & 0.13 & 172.51 & 188.83 & \\
\hline 1904 & 3.5 & 0.13 & 177.58 & 185.19 & \\
\hline 1905 & 3.5 & 0.13 & 177.58 & 181.64 & \\
\hline 1906 & 4.1 & 0.15 & 208.02 & 178.15 & \\
\hline 1907 & 4.7 & 0.17 & 229.95 & 174.74 & \\
\hline 1908 & 4.8 & 0.18 & 243.54 & 171.41 & \\
\hline 1909 & 4.6 & 0.17 & 233.39 & 168.16 & \\
\hline 1910 & 4.1. & 0.15 & 200.59 & 164.97 & \\
\hline 1911 & 3.9 & 0.14 & 190.81 & 161.87 & \\
\hline 1912 & 3.9 & 0.13 & 184.23 & 158.84 & \\
\hline 1913 & 3.8 & 0.13 & 175.27 & 155.88 & \\
\hline 1914 & 3.5 & 0.12 & 159.29 & 153.00 & \\
\hline 1915 & 3.0 & 0.10 & 135.19 & 150.20 & \\
\hline 1916 & 3.0 & 0.10 & 125.68 & 147.47 & \\
\hline 1917 & 3.0 & 0.08 & 107.02 & 144.81 & \\
\hline 1918 & 3.3 & 0.07 & $100 \cdot 24$ & 142.23 & \\
\hline 1919 & 5.1 & 0.10 & 134.87 & 139.73 & \\
\hline 1920 & 6.1 & 0.10 & 139.27 & 137.30 & \\
\hline 1921 & 5.9 & 0.11 & 150.79 & 134.95 & \\
\hline 1922 & 4.3 & 0.09 & 117.34 & 132.67 & \\
\hline 1923 & 3.9 & 0.08 & 104.55 & 130.47 & \\
\hline 1924 & 3.6 & 0.07 & 96.32 & 128.34 & \\
\hline 1925 & 3.3 & 0.06 & 86.11 & 126.29 & \\
\hline 1926 & 3.4 & 0.06 & 87.88 & 124.32 & \\
\hline 1927 & 3.6 & 0.07 & 94.84 & 122.41 & \\
\hline
\end{tabular}


Figure III-4b

PHOSPHATE ROCK (continued)

\begin{tabular}{|c|c|c|c|c|c|}
\hline Year & $\begin{array}{l}\text { Price } \\
\$ / M T \\
\end{array}$ & $\begin{array}{l}\text { Deflated } \\
\text { Price }\end{array}$ & $\begin{array}{c}\text { Index } \\
(1967=100) \\
\end{array}$ & Quadratic Fit & Linear \\
\hline 1928 & 3.6 & 0.07 & 96.13 & 120.59 & \\
\hline 1929 & 3.5 & 0.07 & 93.46 & 118.84 & \\
\hline 1930 & 3.6 & 0.07 & 98.63 & 117.16 & \\
\hline 1931 & 3.7 & 0.08 & 111.15 & 115.56 & \\
\hline 1932 & 3.4 & 0.08 & 113.88 & 114.04 & \\
\hline 1933 & 3.2 & 0.08 & 112.98 & 112.59 & \\
\hline 1934 & 3.5 & 0.09 & 119.57 & 111.22 & \\
\hline 1935 & 3.6 & 0.09 & 119.99 & 109.92 & \\
\hline 1936 & 3.4 & 0.08 & 112.23 & 108.70 & \\
\hline 1937 & 3.3 & 0.08 & 105.13 & 107.55 & \\
\hline 1938 & 3.5 & 0.08 & 113.62 & 106.48 & \\
\hline 1939 & 3.3 & 0.08 & 108.67 & 105.48 & \\
\hline 1940 & 3.1 & 0.07 & 101.11 & 104.56 & \\
\hline 1941 & 3.3 & 0.07 & 102.51 & 103.72 & \\
\hline 1942 & 3.6 & 0.07 & 101.06 & 102.94 & \\
\hline 1943 & 3.7 & 0.07 & 97.85 & 102.25 & \\
\hline 1944 & 3.9 & 0.07 & 101.38 & 101.63 & \\
\hline 1945 & 4.1 & 0.08 & 104.20 & 101.08 & \\
\hline 1946 & 4.5 & 0.08 & 105.38 & 100.62 & \\
\hline 1947 & 5.2 & 0.08 & 106.48 & 100.22 & \\
\hline 1948 & 5.8 & 0.08 & 110.20 & 99.90 & \\
\hline 1949 & 5.7 & 0.08 & 109.36 & 99.66 & \\
\hline 1950 & 5.8 & 0.08 & 110.20 & 99.49 & \\
\hline 1951 & 6.0 & 0.08 & 105.65 & 99.40 & \\
\hline 1952 & 6.0 & 0.08 & 103.39 & 99.38 & \\
\hline 1953 & 6.1 & 0.08 & 104.32 & 99.44 & \\
\hline 1954 & 6.3 & 0.08 & 107.21 & 99.57 & \\
\hline 1955 & 6.3 & 0.08 & 107.61 & 99.78 & \\
\hline 1956 & 6.3 & 0.08 & 106.02 & 100.07 & \\
\hline 1957 & 6.3 & 0.07 & 102.38 & 100.43 & \\
\hline 1958 & 6.2 & 0.07 & 98.08 & 100.86 & \\
\hline 1959 & 6.1 & 0.07 & 95.72 & 101.37 & \\
\hline 1960 & 6.6 & 0.07 & 101.93 & 1.01 .96 & \\
\hline 1961 & 6.9 & 0.08 & 105.49 & 102.62 & \\
\hline 1962 & 6.9 & 0.08 & 104.33 & 103.36 & \\
\hline 1963 & 7.0 & 0.08 & 104.57 & 104.17 & \\
\hline 1964 & 7.0 & 0.08 & 103.22 & 105.05 & \\
\hline 1965 & 7.2 & 0.08 & 104.37 & 106.02 & \\
\hline 1966 & 7.4 & 0.08 & 104.29 & 107.05 & \\
\hline 1967 & 7.3 & 0.07 & 100.00 & 108.17 & \\
\hline 1968 & 6.8 & 0.07 & 89.40 & 109.36 & \\
\hline 1969 & 6.1 & 0.06 & 76.11 & 110.62 & \\
\hline 1970 & 5.8 & 0.05 & 68.32 & 111.96 & \\
\hline 1971 & 5.8 & 0.05 & 65.50 & 113.37 & \\
\hline 1972 & 5.6 & 0.05 & 61.22 & 114.86 & \\
\hline 1973 & 6.2 & 0.05 & 63.81 & 116.43 & \\
\hline 1974 & 12.1 & 0.08 & 112.22 & 118.07 & \\
\hline 1975 & 25.4 & 0.16 & 215.85 & 119.78 & \\
\hline 1976 & 21.3 & 0.12 & 171.14 & 121.58 & \\
\hline 1977 & 17.4 & 0.10 & 131.33 & 123.44 & \\
\hline 1978 & 18.6 & 0.10 & 130.40 & 125.38 & \\
\hline 1979 & 20.0 & 0.09 & 126.03 & 127.40 & \\
\hline
\end{tabular}


Figure III-4b

\section{PHOSPHATE ROCK (continued)}

\begin{tabular}{|c|c|c|c|c|c|}
\hline Year & $\begin{array}{l}\text { Price } \\
\$ / M T \\
\end{array}$ & $\begin{array}{l}\text { Deflated } \\
\text { Price }\end{array}$ & $\begin{array}{c}\text { Index } \\
(1967=100)\end{array}$ & Quadratic Fit & Linear Fit \\
\hline 1980 & 22.8 & 0.09 & 126.55 & 129.49 & \\
\hline 1981 & 26.6 & 0.10 & 133.77 & 131.66 & \\
\hline 1982 & 25.5 & 0.09 & 120.83 & 133.90 & \\
\hline 1983 & 24.0 & 0.08 & 110.18 & 136.22 & \\
\hline 1984 & 24.0 & 0.08 & 105.82 & 138.62 & 65.58 \\
\hline
\end{tabular}


Figure III-5a

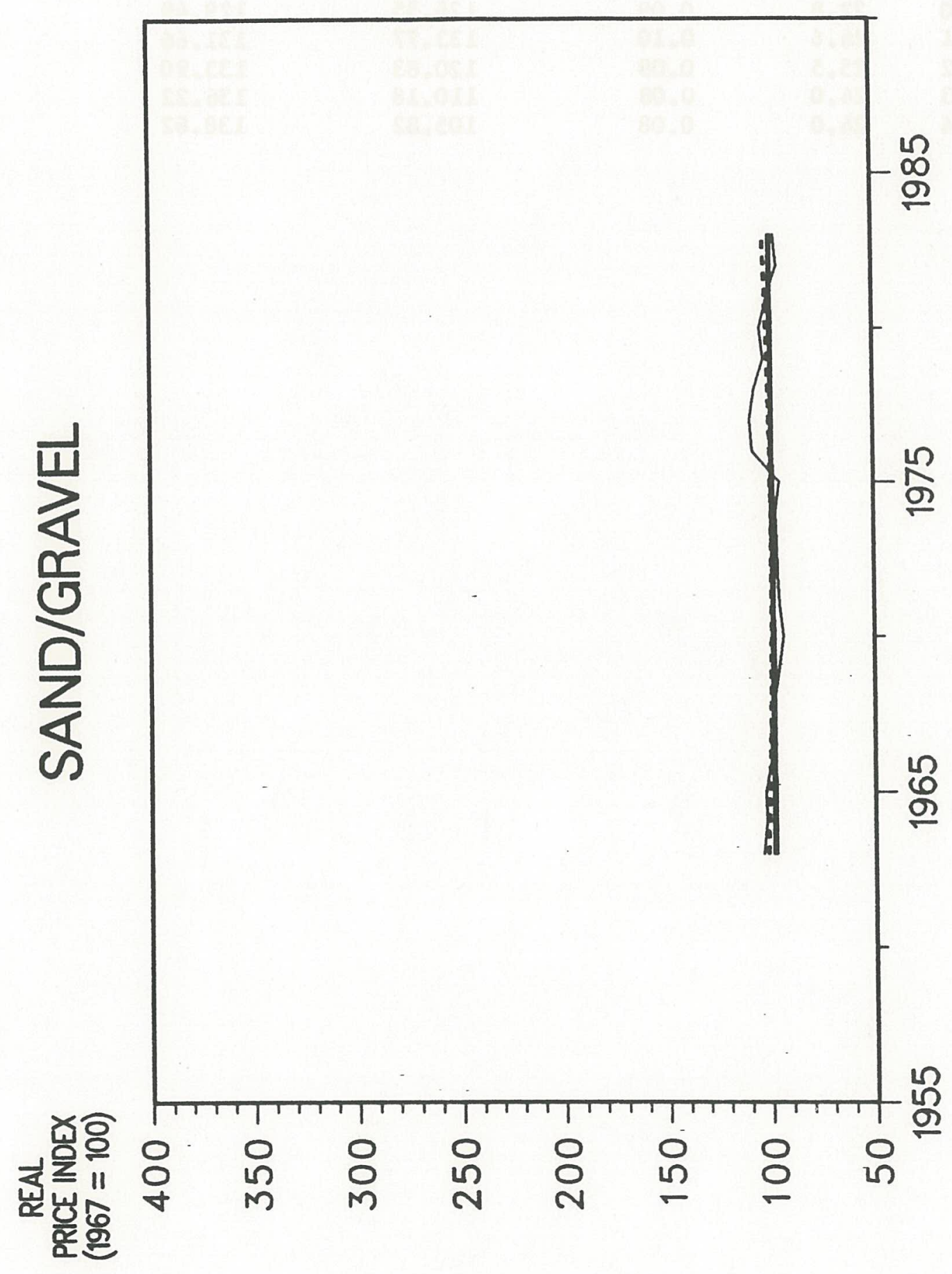


Figure III-5b

CONSTRUCTION SAND \& GRAVEL COMPOSITE

\begin{tabular}{|c|c|c|c|c|c|}
\hline Year & $\begin{array}{l}\text { Price } \\
\$ / \mathrm{ST}\end{array}$ & $\begin{array}{c}\text { Deflated Price } \\
\left(\times 10^{-2}\right)\end{array}$ & $\begin{array}{r}\text { Index } \\
(1967=100) \\
\end{array}$ & Quadratic Fit & Linear Fit \\
\hline 1963 & 0.97 & 1.06 & 103.71 & 101.47 & 98.09 \\
\hline 1964 & 0.97 & 1.04 & 102.37 & 101.03 & \\
\hline 1965 & 0.99 & 1.05 & 102.71 & 100.65 & \\
\hline 1966 & 0.99 & 1.02 & 99.85 & 100.31 & \\
\hline 1967 & 1.02 & 1.02 & 100.00 & 100.02 & \\
\hline 1968 & 1.04 & 1.00 & 97.85 & 99.79 & \\
\hline 1969 & 1.07 & 0.97 & 95.54 & 99.61 & \\
\hline 1970 & 1.11 & 0.95 & 93.57 & 99.47 & \\
\hline 1971 & 1.18 & 0.97 & 95.37 & 99.39 & \\
\hline 1972 & 1.23 & 0.98 & 96.24 & 99.36 & \\
\hline 1973 & 1.31 & 0.98 & 96.49 & 99.38 & \\
\hline 1974 & 1.46 & 0.99 & 96.91 & 99.45 & \\
\hline 1975 & 1.56 & 0.97 & 94.88 & 99.58 & \\
\hline 1976 & 1.88 & 1.10 & 108.10 & 99.75 & \\
\hline 1977 & 2.02 & 1.11 & 109.11 & 99.98 & \\
\hline 1978 & 2.13 & 1.09 & 106.87 & 100.25 & \\
\hline 1979 & 2.27 & 1.04 & 102.37 & 100.58 & \\
\hline 1980 & 2.62 & 1.06 & 104.08 & 100.95 & \\
\hline 1981 & 2.79 & 1.02 & 100.41 & 101.38 & \\
\hline 1982 & 2.82 & 0.98 & 95.63 & 101.86 & \\
\hline 1983 & 2.95 & 0.99 & 96.92 & 102.39 & 99.12 \\
\hline
\end{tabular}


Figure III-6a

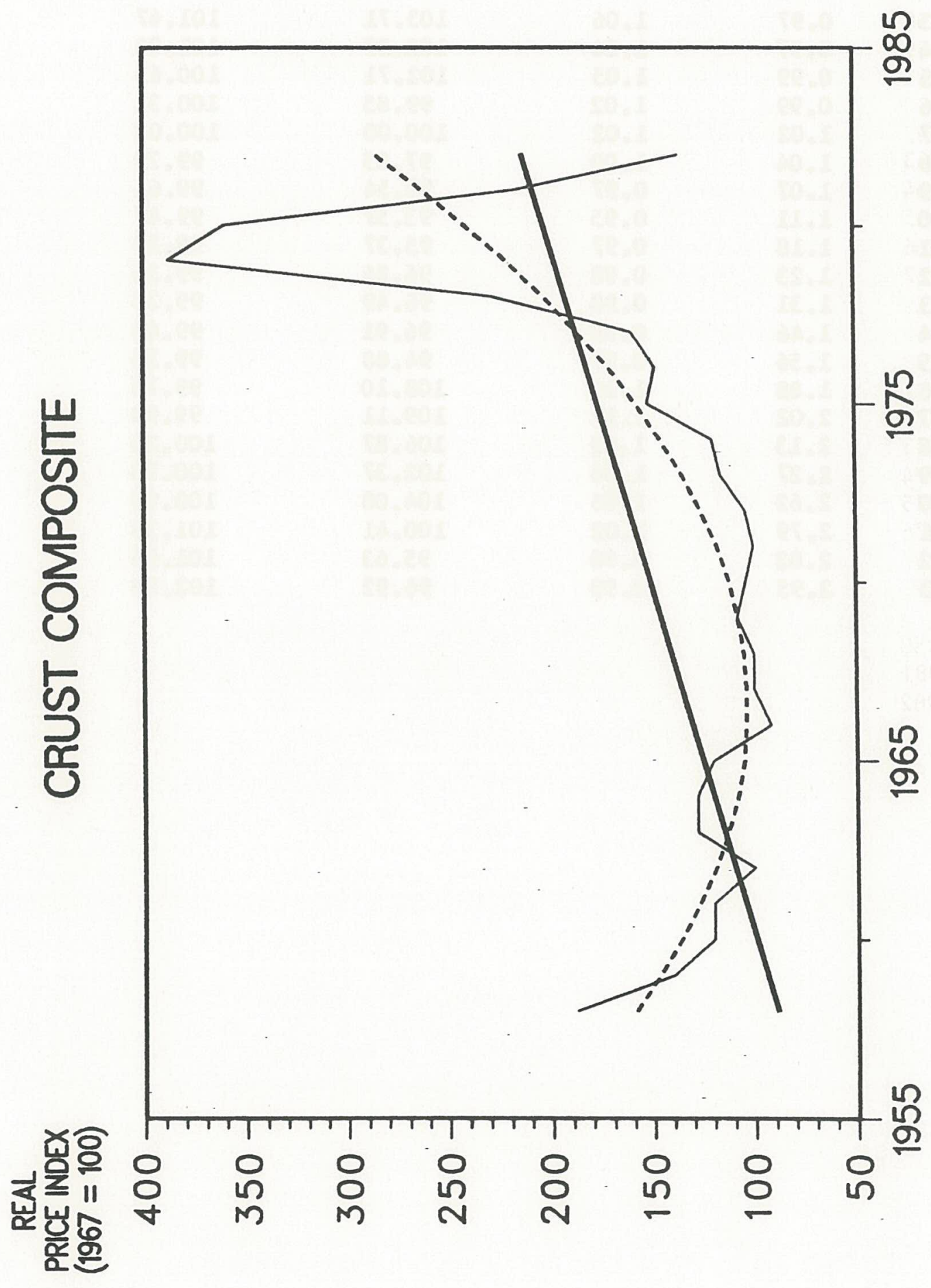


Figure III-6b

CRUST COMPOSITE

\begin{tabular}{lccc} 
& $\begin{array}{c}\text { Index } \\
\text { Year }\end{array}$ & $(1967=100)$ & Quadratic Fit \\
\cline { 2 - 3 } 1958 & 188 & 159 & 89 \\
1959 & 140 & 147 & \\
1960 & 120 & 136 \\
1961 & 120 & 127 \\
1962 & 100 & 119 \\
1963 & 128 & 113 \\
1964 & 128 & 108 \\
1965 & 120 & 105 \\
1966 & 92 & 104 \\
1967 & 100 & 104 \\
1968 & 100 & 105 \\
1969 & 108 & 108 \\
1970 & 104 & 112 \\
1971 & 100 & 118 \\
1972 & 104 & 126 \\
1973 & 116 & 135 \\
1974 & 120 & 146 \\
1975 & 152 & 158 \\
1976 & 148 & 171 \\
1977 & 160 & 187 \\
1978 & 228 & 203 \\
1979 & 338 & 221 \\
1980 & 360 & 241 \\
1981 & 216 & 262 \\
1982 & 136 & 285 \\
& &
\end{tabular}


Figure III-7a

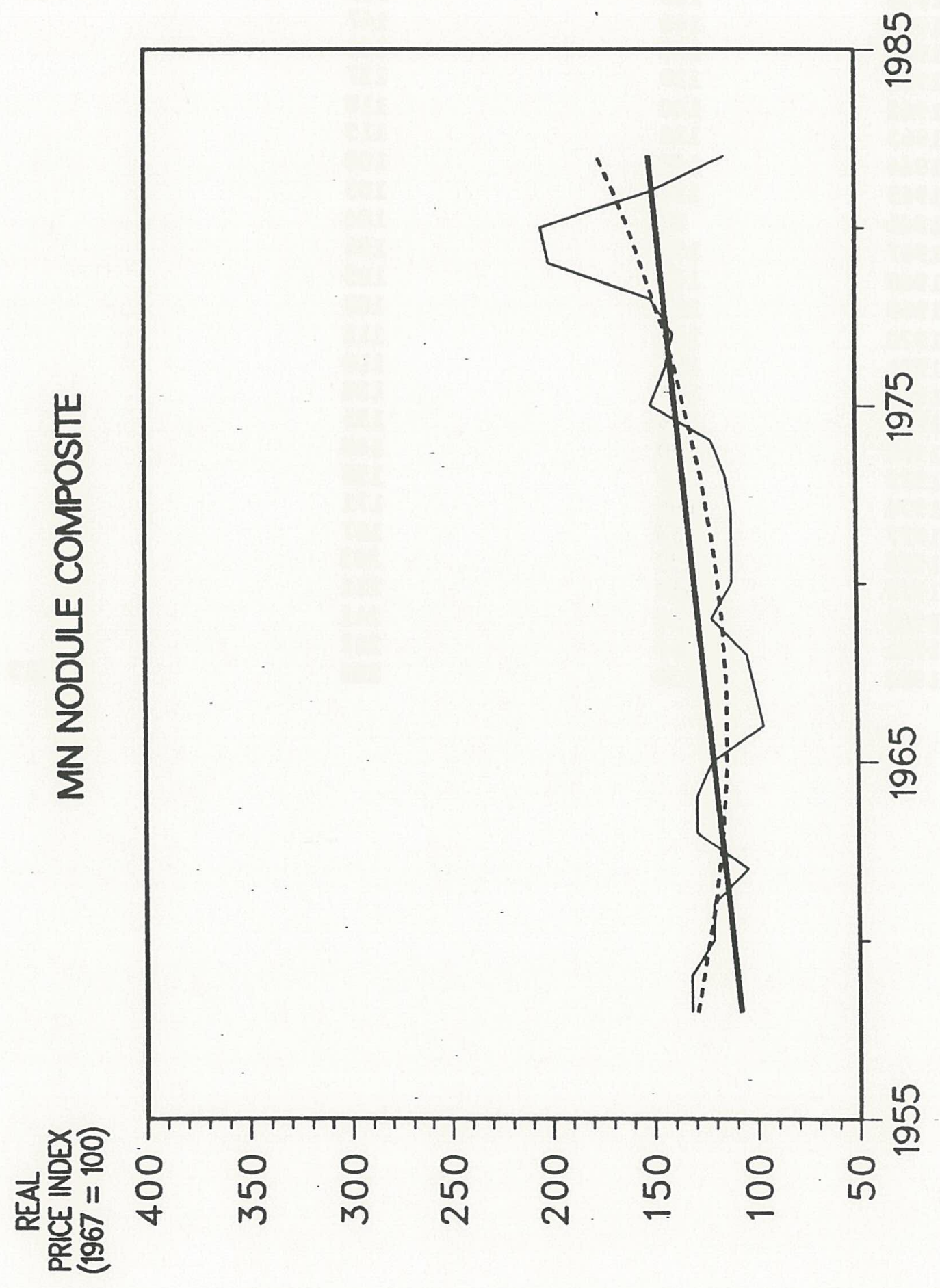


Figure III-7b

MN NODULE COMPOSITE

Index

Year $(1967=100)$

Quadratic Fit

Linear Fit

1958

132

129

108

1959

132

126

1960

121

123

121

104

1962

1963

1964

1965

1966

1967

1968

1969

1970

1971

1972

1973

1974

1975

1976

1977

1978

1979

1980

1981

1982

129

129

121

96

100

104

120

118

116

115

114

114

114

115

116

121

118

120

123

111

111

126

130

134

138

143

149

155

161

168

176 
Figure III-8

COBALT

\begin{tabular}{|c|c|c|c|c|c|}
\hline Year & $\begin{array}{r}\text { Price } \\
\$ / 1 b \\
\end{array}$ & $\begin{array}{l}\text { Def lated Price } \\
\left(\times 10^{-2}\right)\end{array}$ & Index & Quadratic Fit & Linear Fit \\
\hline 1958 & 2.00 & 2.31 & 124.84 & 81.40 & 48.11 \\
\hline 1959 & 1.77 & 2.03 & 109.59 & 82.35 & \\
\hline 1960 & 1.54 & 1.74 & 93.85 & 83.92 & \\
\hline 1961 & 1.50 & 1.67 & 90.49 & 86.10 & \\
\hline 1962 & 1.50 & 1.66 & 89.49 & 88.91 & \\
\hline 1963 & 1.50 & 1.64 & 88.42 & 92.34 & \\
\hline 1964 & 1.50 & 1.61 & 87.28 & 96.40 & \\
\hline 1965 & 1.62 & 1.71 & 92.66 & 101.07 & \\
\hline 1966 & 1.65 & 1.70 & 91.76 & 106.37 & \\
\hline 1967 & 1.85 & 1.85 & 100.00 & 112.29 & \\
\hline 1968 & 1.85 & 1.78 & 95.97 & 118.83 & \\
\hline 1969 & 1.89 & 1.72 & 93.04 & 125.99 & \\
\hline 1970 & 2.20 & 1.89 & 102.25 & 133.77 & \\
\hline 1971 & 2.20 & 1.81 & 98.04 & 142.17 & \\
\hline 1972 & 2.45 & 1.96 & 105.69 & 151.20 & \\
\hline 1973 & 3.00 & 2.25 & 121.83 & 160.85 & \\
\hline 1974 & 3.46 & 2.34 & 126.63 & 171.12 & \\
\hline 1975 & 3.98 & 2.47 & 133.46 & 182.01 & \\
\hline 1976 & 4.44 & 2.60 & 140.76 & 193.52 & \\
\hline 1977 & 5.58 & 3.07 & 166.18 & 205.65 & \\
\hline 1978 & 11.53 & 5.90 & 318.96 & 218.41 & \\
\hline 1979 & 24.58 & 11.31 & 611.15 & 231.79 & \\
\hline 1980 & 25.00 & 10.13 & 547.55 & 245.79 & \\
\hline 1981 & 14.58 & 5.35 & 289.32 & 260.41 & \\
\hline 1982 & 8.56 & 2.96 & 160.05 & 275.65 & \\
\hline 1983 & 5.76 & 1.93 & 104.34 & 291.51 & \\
\hline 1984 & 10.40 & 3.35 & 180.93 & 308.00 & 272.97 \\
\hline
\end{tabular}


Figure III-9

MANGANE SE

\begin{tabular}{|c|c|c|c|c|c|}
\hline Year & $\begin{array}{l}\text { Current } \\
\text { Price* }\end{array}$ & $\begin{array}{c}\text { Def lated Price } \\
\left(x 10^{-2}\right) \\
\end{array}$ & $\begin{array}{c}\text { Index } \\
(1967=100) \\
\end{array}$ & Quadratic Fit & Linear Fit \\
\hline 1958 & 0.06 & 0.07 & 230 & 244 & 193 \\
\hline 1959 & 0.06 & 0.07 & 230 & & \\
\hline 1960 & 0.05 & 0.06 & 187 & & \\
\hline 1961 & 0.05 & 0.06 & 187 & & \\
\hline 1962 & 0.04 & 0.04 & 147 & & \\
\hline 1963 & 0.06 & 0.07 & 217 & & \\
\hline 1964 & 0.06 & 0.07 & 217 & & \\
\hline 1965 & 0.06 & 0.06 & 210 & & \\
\hline 1966 & 0.03 & 0.03 & 103 & & \\
\hline 1967 & 0.03 & 0.03 & 100 & & \\
\hline 1968 & 0.03 & 0.03 & 97 & & \\
\hline 1969 & 0.04 & 0.04 & 120 & & \\
\hline 1970 & 0.04 & 0.03 & 113 & -14.7 & \\
\hline 1971 & 0.04 & 0.03 & 110 & & \\
\hline 1972 & 0.04 & 0.03 & 107 & & \\
\hline 1973 & 0.04 & 0.03 & 100 & & \\
\hline 1974 & 0.04 & 0.03 & 90 & & \\
\hline 1975 & 0.09 & 0.06 & 187 & & \\
\hline 1976 & 0.09 & 0.05 & 177 & & \\
\hline 1977 & 0.09 & 0.05 & 167 & & \\
\hline 1978 & 0.08 & 0.04 & 137 & & \\
\hline 1979 & 0.09 & 0.04 & 137 & & \\
\hline 1980 & 0.10 & 0.04 & 137 & & \\
\hline 1981 & 0.10 & 0.04 & 123 & & \\
\hline 1982 & 0.10 & 0.04 & 117 & 0.44 & -3.3 \\
\hline
\end{tabular}

* Manganese price expressed in $\$ / 1 b$ and calculated using the following formula:

$\frac{\$ a}{L T} \times .47 \times \frac{L T}{22401 b}=$ current price; where a $=$ price of ferromanganese

ore reported annually (until 1982) by the Bureau of Labor Statistics; $\mathrm{LT}=$ long tons; 0.47 = average percent of manganese in ferromanganese ore. From 1958 through 1972, the BLS price of ferromanganese ore was calculated from the index reported in Manthy (1973) according to the following formula:

$\begin{aligned} & \text { Manthy } \\ & \text { Index }\end{aligned} \frac{\$ 94.83}{\mathrm{LT}} \times \frac{1}{100}=\mathrm{a}$; where $\$ 94.83=$ price of ferromanganese ore in 1926. This method of calculating the price of manganese results in slightly higher priced manganese compared to the Bureau of Mines estimates. The preferred Bureau of Labor Statistics series has been terminated. Future series will have to rely upon the Bureau of Mines data. 
Figure III-10

\begin{tabular}{|c|c|c|c|c|c|}
\hline Year & $\begin{array}{r}\text { Price } \\
\$ / 1 \mathrm{~b} \\
\end{array}$ & $\begin{array}{l}\text { Deflated } \\
\text { Price } \\
\end{array}$ & $\begin{array}{c}\text { Index } \\
(1967=100) \\
\end{array}$ & Quadratic Fit & Linear Fit \\
\hline 1913 & 41.2 & 1.39 & 147.60 & 113.57 & 82.25 \\
\hline 1914 & 41.4 & 1.38 & 146.34 & 111.23 & \\
\hline 1915 & 41.3 & 1.36 & 144.55 & 108.98 & \\
\hline 1916 & 41.9 & 1.28 & 136.34 & 106.80 & \\
\hline 1917 & 41.5 & 1.08 & 114.99 & 104.70 & \\
\hline 1918 & 40.8 & 0.90 & 96.26 & 102.67 & \\
\hline 1919 & 40.4 & 0.78 & 82.98 & 100.72 & \\
\hline 1920 & 42.3 & 0.71 & 75.01 & 98.85 & \\
\hline 1921 & 42.0 & 0.78 & 83.37 & 97.05 & \\
\hline 1922 & 38.3 & 0.76 & 81.18 & 95.33 & \\
\hline 1923 & 35.5 & 0.69 & 73.92 & 93.69 & \\
\hline 1924 & 30.3 & 0.59 & 62.97 & 92.13 & \\
\hline 1925 & 32.8 & 0.62 & 66.47 & 90.64 & \\
\hline 1926 & 35.6 & 0.67 & 71.47 & 89.22 & \\
\hline 1927 & 35.4 & 0.68 & 72.43 & 87.89 & \\
\hline 1928 & 37.0 & 0.72 & 76.74 & 86.63 & \\
\hline 1929 & 35.0 & 0.68 & 72.59 & 85.44 & \\
\hline 1930 & 35.0 & 0.70 & 74.48 & 84.34 & \\
\hline 1931 & 35.0 & 0.77 & 81.67 & 83.31 & \\
\hline 1932 & 35.0 & 0.86 & 91.05 & 82.35 & \\
\hline 1933 & 35.0 & 0.90 & 95.98 & 81.48 & \\
\hline 1934 & 35.0 & 0.87 & 92.87 & 80.68 & \\
\hline 1935 & 35.0 & 0.85 & 90.61 & 79.95 & \\
\hline 1936 & 35.0 & 0.84 & 89.73 & 79.31 & \\
\hline 1937 & 35.0 & 0.81 & 86.60 & 78.74 & \\
\hline 1938 & 35.0 & 0.83 & 88.25 & 78.24 & \\
\hline 1939 & 35.0 & 0.84 & 89.52 & 77.83 & \\
\hline 1940 & 35.0 & 0.83 & 88.67 & 77.48 & \\
\hline 1941 & 35.0 & 0.79 & 84.44 & 77.22 & \\
\hline 1942 & 31.5 & 0.65 & 68.68 & 77.03 & \\
\hline 1943 & 31.5 & 0.61 & 64.70 & 76.92 & \\
\hline 1944 & 31.5 & 0.60 & 63.60 & 76.89 & \\
\hline 1945 & 31.5 & 0.58 & 62.18 & 76.93 & \\
\hline 1946 & 35.0 & 0.60 & 63.66 & 77.05 & \\
\hline 1947 & 35.0 & 0.52 & 55.67 & 77.25 & \\
\hline 1948 & 40.0 & 0.55 & 59.03 & 77.52 & \\
\hline 1949 & 40.0 & 0.56 & 59.61 & 77.87 & \\
\hline 1950 & 50.5 & 0.70 & 74.52 & 78.29 & \\
\hline 1951 & 56.5 & 0.73 & 77.27 & 78.80 & \\
\hline 1952 & 56.5 & 0.71 & 75.62 & 79.37 & \\
\hline 1953 & 60.0 & 0.75 & 79.70 & 80.03 & \\
\hline 1954 & 64.5 & 0.80 & 85.25 & 80.76 & \\
\hline 1955 & 64.5 & 0.80 & 85.57 & 81.57 & \\
\hline 1956 & 74.0 & 0.91 & 96.73 & 82.46 & \\
\hline 1957 & 74.0 & 0.88 & 93.40 & 83.42 & \\
\hline 1958 & 74.0 & 0.85 & 90.92 & 84.46 & \\
\hline
\end{tabular}


Figure III-10

\begin{tabular}{|c|c|c|c|c|c|}
\hline Year & $\begin{array}{r}\text { Price } \\
k / 1 b \\
\end{array}$ & $\begin{array}{l}\text { Deflated } \\
\text { Price }\end{array}$ & $\begin{array}{c}\begin{array}{c}\text { Index } \\
(1967=100) \\
\end{array} \\
\end{array}$ & Quadratic Fit & Linear Fit \\
\hline 1959 & 74.0 & 0.85 & 90.19 & 85.57 & \\
\hline 1960 & 74.0 & 0.83 & 88.77 & 86.76 & \\
\hline 1961 & 81.0 & 0.90 & 96.19 & 88.03 & \\
\hline 1962 & 79.0 & 0.87 & 92.78 & 89.38 & \\
\hline 1963 & 79.0 & 0.86 & 91.66 & 90.80 & \\
\hline 1964 & 79.0 & 0.85 & 90.48 & 92.30 & \\
\hline 1965 & 78.0 & 0.83 & 87.82 & 93.87 & \\
\hline 1966 & 85.0 & 0.87 & 93.05 & 95.52 & \\
\hline 1967 & 94.0 & 0.94 & 100.01 & 97.25 & \\
\hline 1968 & 103.0 & 0.99 & 105.17 & 99.05 & \\
\hline 1969 & 128.0 & 1.17 & 124.04 & 100.94 & \\
\hline 1970 & 128.0 & 1.10 & 117.10 & 102.89 & \\
\hline 1971 & 133.0 & 1.10 & 116.66 & 104.93 & \\
\hline 1972 & 140.0 & 1.12 & 118.88 & 107.04 & \\
\hline 1973 & 153.0 & 1.15 & 122.31 & 109.23 & \\
\hline 1974 & 174.0 & 1.18 & 125.35 & 111.49 & \\
\hline 1975 & 203.0 & 1.26 & 133.99 & 113.83 & \\
\hline 1976 & 220.0 & 1.29 & 137.29 & 116.25 & \\
\hline 1977 & 217.0 & 1.20 & 127.21 & 118.74 & \\
\hline 1978 & 208.0 & 1.06 & 113.26 & 121.31 & \\
\hline 1979 & 241.0 & 1.10 & 117.95 & 123.96 & \\
\hline 1980 & 341.0 & 1.38 & 147.01 & 126.68 & \\
\hline 1981 & 343.0 & 1.26 & 133.98 & 129.48 & \\
\hline 1982 & 320.0 & 1.11 & 117.77 & 132.36 & \\
\hline 1983 & 220.0 & 0.74 & 78.45 & 135.32 & \\
\hline 1984 & 222.0 & 0.71 & 76.02 & 138.35 & 104.91 \\
\hline
\end{tabular}


Figure III-11

\begin{tabular}{|c|c|c|c|c|c|}
\hline \multirow[b]{2}{*}{ Year } & \multicolumn{4}{|c|}{ COPPER } & \multirow[b]{2}{*}{ Linear Fit } \\
\hline & $\begin{array}{r}\text { Price } \\
\& / 1 b \\
\end{array}$ & $\begin{array}{l}\text { Def lated } \\
\text { Price }\end{array}$ & $\begin{array}{c}\begin{array}{c}\text { Index } \\
(1967=100) \\
\end{array} \\
\end{array}$ & Quadratic Fit & \\
\hline 1870 & 18.6 & 0.49 & 126.82 & 169.16 & 141.36 \\
\hline 1871 & 20.3 & 0.56 & 146.10 & 167.09 & \\
\hline 1872 & 30.8 & 0.86 & 221.67 & 165.04 & \\
\hline 1873 & 26.6 & 0.74 & 191.45 & 163.02 & \\
\hline 1874 & 22.8 & 0.67 & 173.75 & 161.02 & \\
\hline 1875 & 21.4 & 0.65 & 168.02 & 159.05 & \\
\hline 1876 & 18.4 & 0.58 & 148.98 & 157.10 & \\
\hline 1877 & 17.8 & 0.56 & 144.12 & 155.18 & \\
\hline 1878 & 15.0 & 0.52 & 134.02 & 153.29 & \\
\hline 1879 & 15.0 & 0.54 & 138.80 & 151.42 & \\
\hline 1880 & 17.7 & 0.61 & 158.14 & 149.58 & \\
\hline 1881 & 15.4 & 0.53 & 137.59 & 147.76 & \\
\hline 1882 & 17.0 & 0.59 & 151.89 & 145.97 & \\
\hline 1883 & 14.2 & 0.51 & 131.40 & 144.20 & \\
\hline 1884 & 13.0 & 0.48 & 124.75 & 142.47 & \\
\hline 1885 & 10.4 & 0.39 & 99.80 & 140.75 & \\
\hline 1886 & 9.4 & 0.35 & 90.21 & 139.07 & \\
\hline 1887 & 9.3 & 0.34 & 89.25 & 137.41 & \\
\hline 1888 & 15.4 & 0.57 & 147.78 & 135.77 & \\
\hline 1889 & 13.5 & 0.50 & 129.55 & 134.16 & \\
\hline 1890 & 15.2 & 0.56 & 145.86 & 132.58 & \\
\hline 1891 & 12.6 & 0.47 & 120.91 & 131.02 & \\
\hline 1892 & 11.1 & 0.41 & 106.52 & 129.49 & \\
\hline 1893 & 10.5 & 0.39 & 100.76 & 127.99 & \\
\hline 1894 & 9.1 & 0.35 & 90.69 & 126.51 & \\
\hline 1895 & 10.4 & 0.42 & 107.79 & 125.05 & \\
\hline 1896 & 10.6 & 0.42 & 109.86 & 123.62 & \\
\hline 1897 & 10.9 & 0.44 & 112.97 & 122.22 & \\
\hline 1898 & 11.5 & 0.46 & 119.19 & 120.85 & \\
\hline 1899 & 17.0 & 0.68 & 176.19 & 119.50 & \\
\hline 1900 & 16.0 & 0.64 & 165.82 & 118.17 & \\
\hline 1901 & 16.3 & 0.65 & 168.93 & 116.87 & \\
\hline 1902 & 11.6 & 0.45 & 115.60 & 115.60 & \\
\hline 1903 & 13.2 & 0.49 & 126.67 & 114.36 & \\
\hline 1904 & 12.6 & 0.47 & 120.91 & 113.14 & \\
\hline 1905 & 15.2 & 0.56 & 145.86 & 111.94 & \\
\hline 1906 & 19.3 & 0.71 & 185.21 & 110.77 & \\
\hline 1907 & 20.0 & 0.71 & 185.07 & 109.63 & \\
\hline 1908 & 13.2 & 0.49 & 126.67 & 108.51 & \\
\hline 1909 & 13.0 & 0.48 & 124.75 & 107.42 & \\
\hline 1910 & 12.7 & 0.45 & 117.52 & 106.36 & \\
\hline 1911 & 12.4 & 0.44 & 114.74 & 105.32 & \\
\hline 1912 & 16.3 & 0.56 & 145.63 & 104.31 & \\
\hline 1913 & 15.3 & 0.52 & 133.48 & 103.32 & \\
\hline 1914 & 13.6 & 0.45 & 117.07 & 102.36 & \\
\hline 1915 & 17.3 & 0.57 & 147.45 & 101.42 & \\
\hline
\end{tabular}


Figure III-11

\begin{tabular}{|c|c|c|c|c|c|}
\hline Year & $\begin{array}{r}\text { Price } \\
\$ / 1 \mathrm{~b} \\
\end{array}$ & $\begin{array}{l}\text { Deflated } \\
\text { Price }\end{array}$ & $\begin{array}{c}\text { Index } \\
(1967=100) \\
\end{array}$ & Quadratic Fit & Linear Fit \\
\hline 1916 & 27.2 & 0.83 & 215.52 & 100.51 & \\
\hline 1917 & 27.2 & 0.71 & 183.53 & 99.63 & \\
\hline 1918 & 24.6 & 0.55 & 141.33 & 98.77 & \\
\hline 1919 & 18.7 & 0.36 & 93.54 & 97.94 & \\
\hline 1920 & 17.5 & 0.29 & 75.57 & 97.13 & \\
\hline 1921 & 12.5 & 0.23 & 60.42 & 96.35 & \\
\hline 1922 & 13.4 & 0.27 & 69.16 & 95.60 & \\
\hline 1923 & 14.4 & 0.28 & 73.01 & 94.87 & \\
\hline 1924 & 13.0 & 0.25 & 65.79 & 94.17 & \\
\hline 1925 & 14.0 & 0.27 & 69.09 & 93.49 & \\
\hline 1926 & 13.8 & 0.26 & 67.46 & 92.84 & \\
\hline 1927 & 12.9 & 0.25 & 64.28 & 92.22 & \\
\hline 1928 & 14.6 & 0.28 & 73.74 & 91.62 & \\
\hline 1929 & 18.1 & 0.35 & 91.42 & 91.05 & \\
\hline 1930 & 13.0 & 0.26 & 67.37 & 90.50 & \\
\hline 1931 & 8.1 & 0.18 & 46.02 & 89.98 & \\
\hline 1932 & 5.6 & 0.14 & 35.48 & 89.49 & \\
\hline 1933 & 7.0 & 0.18 & 46.74 & 89.02 & \\
\hline 1934 & 8.4 & 0.21 & 54.28 & 88.57 & \\
\hline 1935 & 8.6 & 0.21 & 54.21 & 88.16 & \\
\hline 1936 & 9.5 & 0.23 & 59.31 & 87.76 & \\
\hline 1937 & 13.2 & 0.31 & 79.54 & 87.40 & \\
\hline 1938 & 10.0 & 0.24 & 61.40 & 87.06 & \\
\hline 1939 & 11.0 & 0.26 & 68.51 & 86.75 & \\
\hline 1940 & 11.3 & 0.27 & 69.71 & 86.46 & \\
\hline 1941 & 11.8 & 0.27 & 69.33 & 86.20 & \\
\hline 1942 & 11.8 & 0.24 & 62.65 & 85.96 & \\
\hline 1943 & 11.8 & 0.23 & 59.02 & 85.75 & \\
\hline 1944 & 11.8 & 0.22 & 58.01 & 85.57 & \\
\hline 1945 & 11.8 & 0.22 & 56.72 & 85.41 & \\
\hline 1946 & 13.8 & 0.24 & 61.12 & 85.28 & \\
\hline 1947 & 21.0 & 0.31 & 81.33 & 85.17 & \\
\hline 1948 & 22.0 & 0.31 & 79.06 & 85.09 & \\
\hline 1949 & 19.2 & 0.27 & 69.67 & 85.04 & \\
\hline 1950 & 21.2 & 0.29 & 76.18 & 85.01 & \\
\hline 1951 & 24.2 & 0.31 & 80.59 & 85.01 & \\
\hline 1952 & 24.2 & 0.30 & 78.87 & 85.03 & \\
\hline 1953 & 28.8 & 0.36 & 93.16 & 85.08 & \\
\hline 1954 & 29.7 & 0.37 & 95.59 & 85.15 & \\
\hline 1955 & 37.5 & 0.47 & 121.15 & 85.25 & \\
\hline 1956 & 41.8 & 0.51 & 133.05 & 85.38 & \\
\hline 1957 & 29.6 & 0.35 & 90.98 & 85.53 & \\
\hline 1958 & 26.3 & 0.30 & 78.69 & 85.71 & \\
\hline 1959 & 30.7 & 0.35 & 91.12 & 85.92 & \\
\hline 1960 & 32.1 & 0.36 & 93.77 & 86.15 & \\
\hline 1961 & 30.0 & 0.33 & 86.75 & 86.40 & \\
\hline
\end{tabular}


Figure III-11

\begin{tabular}{|c|c|c|c|c|c|}
\hline Year & $\begin{array}{r}\text { Price } \\
\$ / 1 \mathrm{~b} \\
\end{array}$ & $\begin{array}{l}\text { Def lated } \\
\text { Price }\end{array}$ & $\begin{array}{c}\text { Index } \\
(1967=100) \\
\end{array}$ & Quadratic Fit & Linear Fit \\
\hline 1962 & 30.8 & 0.34 & 88.08 & 86.69 & \\
\hline 1963 & 30.8 & 0.34 & 87.03 & 87.00 & \\
\hline 1964 & 32.6 & 0.35 & 90.92 & 87.33 & \\
\hline 1965 & 35.4 & 0.37 & 97.06 & 87.69 & \\
\hline 1966 & 36.6 & 0.38 & 97.56 & 88.08 & \\
\hline 1967 & 38.6 & 0.39 & 100.01 & 88.49 & \\
\hline 1968 & 42.2 & 0.40 & 104.93 & 88.93 & \\
\hline 1969 & 47.9 & 0.44 & 113.03 & 89.39 & \\
\hline 1970 & 58.2 & 0.50 & 129.66 & 89.88 & \\
\hline 1971 & 52.0 & 0.43 & 111.07 & 90.39 & \\
\hline 1972 & 51.2 & 0.41 & 105.87 & 90.94 & \\
\hline 1973 & 59.5 & 0.45 & 115.83 & 91.50 & \\
\hline 1974 & 77.3 & 0.52 & 135.60 & 92.10 & \\
\hline 1975 & 64.2 & 0.40 & 103.19 & 92.72 & \\
\hline 1976 & 69.6 & 0.41 & 105.77 & 93.36 & \\
\hline 1977 & 66.8 & 0.37 & 95.36 & 94.03 & \\
\hline 1978 & 66.5 & 0.34 & 88.18 & 94.73 & \\
\hline 1979 & 93.3 & 0.43 & 111.20 & 95.45 & \\
\hline 1980 & 101.3 & 0.41 & 106.35 & 96.20 & \\
\hline 1981 & 84.2 & 0.31 & 80.09 & 96.98 & \\
\hline 1982 & 72.8 & 0.25 & 65.25 & 97.78 & \\
\hline 1983 & 76.5 & 0.26 & 66.42 & 98.60 & \\
\hline 1984 & 66.9 & 0.22 & 55.79 & 99.46 & 71.67 \\
\hline
\end{tabular}


Figure III-12a

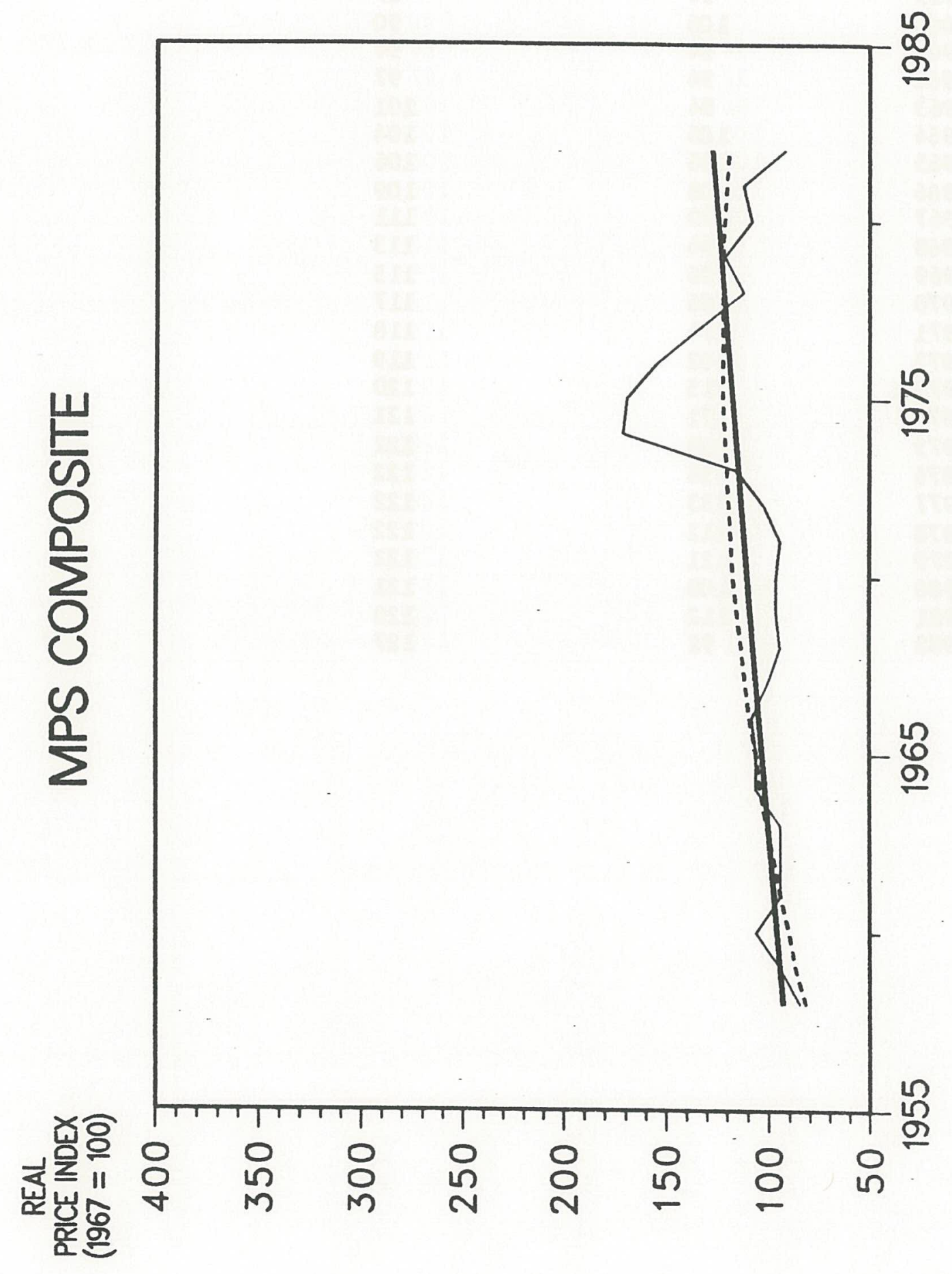


Figure III-12b

$-64-$

Marine Polymetallic Sulfide Composite

\begin{tabular}{l} 
Year \\
\hline 1958 \\
1959 \\
1960 \\
1961 \\
1962 \\
1963 \\
1964 \\
1965 \\
1966 \\
1967 \\
1968 \\
1969 \\
1970 \\
1971 \\
1972 \\
1973 \\
1974 \\
1975 \\
1976 \\
1977 \\
1978 \\
1979 \\
1980 \\
1981 \\
1982
\end{tabular}

\begin{abstract}
$1967=100)$
\end{abstract}
85

94

106

94

94

94

106

106

108

100

94

96

96

94

102

115

171

169

154

133

112

121

108

112

92
Quadratic Fit

82

87

90

94

97

101

104

106

109

111

113

115

117

118

119

120

121

122

122

122

122

122

121

120

127
Linear Fit

93

127 
Figure III-13

\begin{tabular}{|c|c|c|c|c|c|}
\hline Year & $\begin{array}{r}\text { Price } \\
\$ / 1 \mathrm{~b} \\
\end{array}$ & $\begin{array}{l}\text { Def lated } \\
\text { Price }\end{array}$ & $\begin{array}{c}\begin{array}{c}\text { Index } \\
(1967=100) \\
\end{array} \\
\end{array}$ & Quadratic Fit & Linear Fit \\
\hline 1870 & 7.0 & 0.18 & 132.52 & 145.94 & 134.99 \\
\hline 1871 & 7.0 & 0.19 & 139.88 & 145.12 & \\
\hline 1872 & 7.0 & 0.19 & 139.88 & 144.32 & \\
\hline 1873 & 8.6 & 0.24 & 171.86 & 143.53 & \\
\hline 1874 & 7.0 & 0.21 & 148.11 & 142.74 & \\
\hline 1875 & 7.4 & 0.22 & 161.32 & 141.97 & \\
\hline 1876 & 7.2 & 0.23 & 161.87 & 141.21 & \\
\hline 1877 & 5.9 & 0.18 & 132.64 & 140.45 & \\
\hline 1878 & 4.5 & 0.16 & 111.63 & 139.71 & \\
\hline 1879 & 4.5 & 0.16 & 115.62 & 138.97 & \\
\hline 1880 & 5.5 & 0.19 & 136.44 & 138.25 & \\
\hline 1881 & 5.2 & 0.18 & 129.00 & 137.53 & \\
\hline 1882 & 5.3 & 0.18 & 131.48 & 136.83 & \\
\hline 1883 & 4.5 & 0.16 & 115.62 & 136.13 & \\
\hline 1884 & 4.4 & 0.16 & 117.24 & 135.45 & \\
\hline 1885 & 4.3 & 0.16 & 114.57 & 134.77 & \\
\hline 1886 & 4.4 & 0.16 & 117.24 & 134.11 & \\
\hline 1887 & 4.6 & 0.17 & 122.56 & 133.45 & \\
\hline 1888 & 4.9 & 0.18 & 130.56 & 132.80 & \\
\hline 1889 & 5.0 & 0.19 & 133.22 & 132.17 & \\
\hline 1890 & 5.6 & 0.21 & 149.21 & 131.54 & \\
\hline 1891 & 5.0 & 0.19 & 133.22 & 130.92 & \\
\hline 1892 & 4.6 & 0.17 & 122.56 & 130.32 & \\
\hline 1893 & 4.1 & 0.15 & 109.24 & 129.72 & \\
\hline 1894 & 3.5 & 0.13 & 96.84 & 129.13 & \\
\hline 1895 & 3.6 & 0.14 & 103.59 & 128.55 & \\
\hline 1896 & 3.9 & 0.16 & 112.23 & 127.99 & \\
\hline 1897 & 4.1 & 0.16 & 117.98 & 127.43 & \\
\hline 1898 & 4.6 & 0.18 & 132.37 & 126.88 & \\
\hline 1899 & 5.8 & 0.23 & 166.90 & 126.34 & \\
\hline 1900 & 4.4 & 0.18 & 126.61 & 125.81 & \\
\hline 1901 & 4.1 & 0.16 & 117.98 & 125.29 & \\
\hline 1902 & 4.9 & 0.19 & 135.58 & 124.78 & \\
\hline 1903 & 5.6 & 0.21 & 149.21 & 124.28 & \\
\hline 1904 & 5.2 & 0.19 & 138.55 & 123.79 & \\
\hline 1905 & 6.0 & 0.22 & 159.87 & 123.31 & \\
\hline 1906 & 6.3 & 0.23 & 167.86 & 122.84 & \\
\hline 1907 & 6.2 & 0.22 & 159.30 & 122.38 & \\
\hline 1908 & 4.7 & 0.17 & 125.23 & 121.93 & \\
\hline 1909 & 5.5 & 0.20 & 146.54 & 121.49 & \\
\hline 1910 & 5.7 & 0.20 & 146.45 & 121.06 & \\
\hline 1911 & 5.9 & 0.21 & 151.59 & 120.64 & \\
\hline 1912 & 7.1 & 0.24 & 176.13 & 120.23 & \\
\hline 1913 & 5.8 & 0.20 & 140.49 & 119.83 & \\
\hline 1914 & 5.3 & 0.18 & 126.67 & 119.43 & \\
\hline 1915 & 14.4 & 0.47 & 340.77 & 119.05 & \\
\hline 1916 & 13.8 & 0.42 & 303.61 & 118.68 & \\
\hline 1917 & 9.1 & 0.24 & 170.48 & 118.32 & \\
\hline 1918 & 8.3 & 0.18 & 132.40 & 117.96 & \\
\hline 1919 & 7.4 & 0.14 & 102.77 & 117.62 & \\
\hline 1920 & 8.1 & 0.14 & 97.12 & 117.29 & \\
\hline
\end{tabular}


Figure III-13

ZINC (contd.)

\begin{tabular}{|c|c|c|c|c|c|}
\hline Year & $\begin{array}{r}\text { Price } \\
\& / 1 \mathrm{~b} \\
\end{array}$ & $\begin{array}{l}\text { Def lated } \\
\text { Price }\end{array}$ & $\begin{array}{c}\text { Index } \\
(1967=100) \\
\end{array}$ & Quadratic Fit & Linear Fit \\
\hline 1921 & 5.2 & 0.10 & 69.79 & 116.97 & \\
\hline 1922 & 6.1 & 0.12 & 87.42 & 116.65 & \\
\hline 1923 & 7.0 & 0.14 & 98.55 & 116.35 & \\
\hline 1924 & 6.7 & 0.13 & 94.14 & 116.05 & \\
\hline 1925 & 8.0 & 0.15 & 109.62 & 115.77 & \\
\hline 1926 & 7.7 & 0.15 & 104.52 & 115.49 & \\
\hline 1927 & 6.6 & 0.13 & 91.31 & 115.23 & \\
\hline 1928 & 6.4 & 0.12 & 89.75 & 114.98 & \\
\hline 1929 & 6.8 & 0.13 & 95.36 & 114.73 & \\
\hline 1930 & 4.9 & 0.10 & 70.50 & 114.49 & \\
\hline 1931 & 4.0 & 0.09 & 63.11 & 114.27 & \\
\hline 1932 & 3.3 & 0.08 & 58.04 & 114.05 & \\
\hline 1933 & 4.4 & 0.11 & 81.58 & 113.85 & \\
\hline 1934 & 4.5 & 0.11 & 80.73 & 113.65 & \\
\hline 1935 & 4.7 & 0.11 & 82.27 & 113.46 & \\
\hline 1936 & 5.3 & 0.13 & 91.88 & 113.29 & \\
\hline 1937 & 6.9 & 0.16 & 115.44 & 113.12 & \\
\hline 1938 & 5.0 & 0.12 & 85.24 & 112.96 & \\
\hline 1939 & 5.5 & 0.13 & 95.11 & 112.82 & \\
\hline 1940 & 6.7 & 0.16 & 114.76 & 112.68 & \\
\hline 1941 & 7.9 & 0.18 & 128.87 & 112.55 & \\
\hline 1942 & 8.7 & 0.18 & 128.25 & 112.43 & \\
\hline 1943 & 8.7 & 0.17 & 120.83 & 112.32 & \\
\hline 1944 & 8.6 & 0.16 & 117.40 & 112.23 & \\
\hline 1945 & 8.6 & 0.16 & 114.78 & 112.14 & \\
\hline 1946 & 9.1 & 0.16 & 111.91 & 112.06 & \\
\hline 1947 & 11.0 & 0.16 & 118.29 & 111.99 & \\
\hline 1948 & 14.2 & 0.20 & 141.68 & 111.93 & \\
\hline 1949 & 12.9 & 0.18 & 129.98 & 111.88 & \\
\hline 1950 & 14.6 & 0.20 & 145.68 & 111.84 & \\
\hline 1951 & 18.6 & 0.24 & 171.99 & 111.81 & \\
\hline 1952 & 17.0 & 0.21 & 153.83 & 111.79 & \\
\hline 1953 & 11.5 & 0.14 & 103.28 & 111.78 & \\
\hline 1954 & 11.2 & 0.14 & 100.09 & 111.78 & \\
\hline 1955 & 12.8 & 0.16 & 114.82 & 111.79 & \\
\hline 1956 & 14.0 & 0.17 & 123.73 & 111.81 & \\
\hline 1957 & 11.9 & 0.14 & 101.55 & 111.84 & \\
\hline 1958 & 10.3 & 0.12 & 85.56 & 111.88 & \\
\hline 1959 & 11.5 & 0.13 & 94.77 & 111.92 & \\
\hline 1960 & 13.0 & 0.15 & 105.44 & 111.98 & \\
\hline 1961 & 11.6 & 0.13 & 93.14 & 112.05 & \\
\hline 1962 & 11.6 & 0.13 & 92.11 & 112.13 & \\
\hline 1963 & 12.0 & 0.13 & 94.14 & 112.22 & \\
\hline 1964 & 13.6 & 0.15 & 105.32 & 112.31 & \\
\hline 1965 & 14.5 & 0.15 & 110.38 & 112.42 & \\
\hline 1966 & 14.5 & 0.15 & 107.32 & 112.54 & \\
\hline 1967 & 13.9 & 0.14 & 100.00 & 112.66 & \\
\hline 1968 & 13.5 & 0.13 & 93.20 & 112.80 & \\
\hline 1969 & 14.7 & 0.13 & 96.31 & 112.95 & \\
\hline 1970 & 15.3 & 0.13 & 94.64 & 113.10 & \\
\hline
\end{tabular}


Figure III-13

\begin{tabular}{|c|c|c|c|c|c|}
\hline Year & $\begin{array}{r}\text { Price } \\
\$ / 1 b \\
\end{array}$ & $\begin{array}{l}\text { Def lated } \\
\text { Price } \\
\end{array}$ & $\begin{array}{c}\text { Index } \\
(1967=100) \\
\end{array}$ & Quadratic Fit & Linear Fit \\
\hline 1971 & 16.1 & 0.13 & 95.49 & 113.27 & \\
\hline 1972 & 17.8 & 0.14 & 102.20 & 113.44 & \\
\hline 1973 & 20.7 & 0.16 & 111.88 & 113.63 & \\
\hline 1974 & 36.0 & 0.24 & 175.34 & 113.82 & \\
\hline 1975 & 39.0 & 0.24 & 174.05 & 114.03 & \\
\hline 1976 & 37.0 & 0.22 & 156.12 & 114.24 & \\
\hline 1977 & 34.4 & 0.19 & 136.35 & 114.47 & \\
\hline 1978 & 31.0 & 0.16 & 114.13 & 114.70 & \\
\hline 1979 & 37.3 & 0.17 & 123.43 & 114.95 & \\
\hline 1980 & 37.4 & 0.15 & 109.02 & 115.20 & \\
\hline 1981 & 44.6 & 0.16 & 117.79 & 115.46 & \\
\hline 1982 & 38.5 & 0.13 & 95.80 & 115.74 & \\
\hline 1983 & 41.4 & 0.14 & 99.81 & 116.02 & \\
\hline 1984 & 48.6 & 0.16 & 112.53 & 116.31 & 105.46 \\
\hline
\end{tabular}




\section{Section IV: Elasticity of Reserves}

One way to examine the potential for resource depletion is to determine how rapidly consumption of a mineral increases relative to additions to the size of the resource. It is generally thought that the depletion of onshore resources in the face of stable or rising consumption trends will trigger the search for and recovery of other resources, including ocean minerals. Mineral consumption might increase because of population expansion, technological advances, and economic growth. As minerals are produced and consumed, current economic resources are depleted. Usually, this depletion is more than compensated for through increases in resources from higher prices (expanding economically accessible quantities) exploration effort and new discovery, and technological advances that allow the development of lower-grade or less-accessible minerals. Changes in other basic economic phenomena such as substitution, recycling, and conservation also condition the rate of depletion. Although long-term price changes are probably the most useful scarcity (depletion) indicator, idiosyncratic factors in individual minerals markets may be hidden by an analysis of price alone. Thus it is useful to examine consumption behavior, changes in the size of the resource, as well as price movements, to focus in on those minerals that could become promising offshore prospects.

We compare the rate of change in reported reserves with the rate of change in consumption and with the rate of change in price for those minerals that might be recovered from seabed resources. This comparison is conducted over the 16 year period from 1970 to 1985, during which consistent data was available from the U.S. Bureau of Mines, Mineral Facts and Problems (BOM/MFP) (Tables IV-1, IV-2, IV-3, IV-4, IV-5). "Reserves," a more restrictive category than "resources," has been used here because BOM has not reported world resources consistently over that period but instead recently has replaced that category with "reserve base." Because of this replacement, it has not been possible to obtain data on the change in size of world resources over the 16 year period.

Figures IV-1 and IV-2 show the results of the comparisons. The units represent percent increases or decreases in consumption or price, along the $\mathrm{x}$-axes and size of reported reserves along the y-axes. Because these are 
percentage changes, they show the "elasticity" or the ratio of the rate of change in the size of reserves to changes in consumption or price. Figure IV-1 is the "consumption elasticity of reserves" and figure IV-2 is the "price elasticity of reserves." The diagonal line extending from quadrant III to quadrant $I$ is a reference line indicating relative rates of change. To the right of the reference line, consumption or price is either (1) increasing faster than the increase in the size of reserves (quadrant I); (2) increasing as reserves decrease (quadrant IV); or (3) decreasing more slowly than the decrease in the size of reserves (quadrant III). To the left of the reference line, consumption or price is either (4) decreasing faster than decreases in the size of reserves (quadrant III); (5) decreasing as reserves increase (quadrant II); or (6) increasing more slowly than increases in the size of reserves (quadrant I). Tables IV-1, IV-2, IV-3, IV-4, and IV-5 present the data incorporated into the figures.

Several general statements can be made. First, minerals that are positioned to the right of the reference line show a relatively inelastic response in reserves to changes in consumption or price relative to those minerals positioned to the left of the line. Those minerals in quadrant IV (all to the right of the line) fall into the extreme case of decreases in the size of reserves with increases in consumption or price. The minerals such as yttrium and chromite in figure IV-1 and sulfur and phosphate in figure IV-2 may deserve closer study. In particular, one might conclude from this analysis alone that these minerals are depleting.

This type of analysis appears most useful as a method to help set priorities for more detailed analyses of prospective seabed minerals. Using both figures, one might want to make a closer examination of the markets for sulfur and phosphate, for example, which over the 16 year period show decreases in the size of reserves while both consumption and price have increased. Other minerals like manganese and hafnium, for example, might receive a lower priority.

There are shortcomings to this type of analysis. They include the short time period, the generally small changes in any of the variables (although gold has a very large increase in the size of reserves), and the reliance upon reserve data that may be affected, for example, by tax policy. Used in conjunction with other information, however, elasticity of reserves can be a useful tool for examining the relative potential for depletion of resources. 


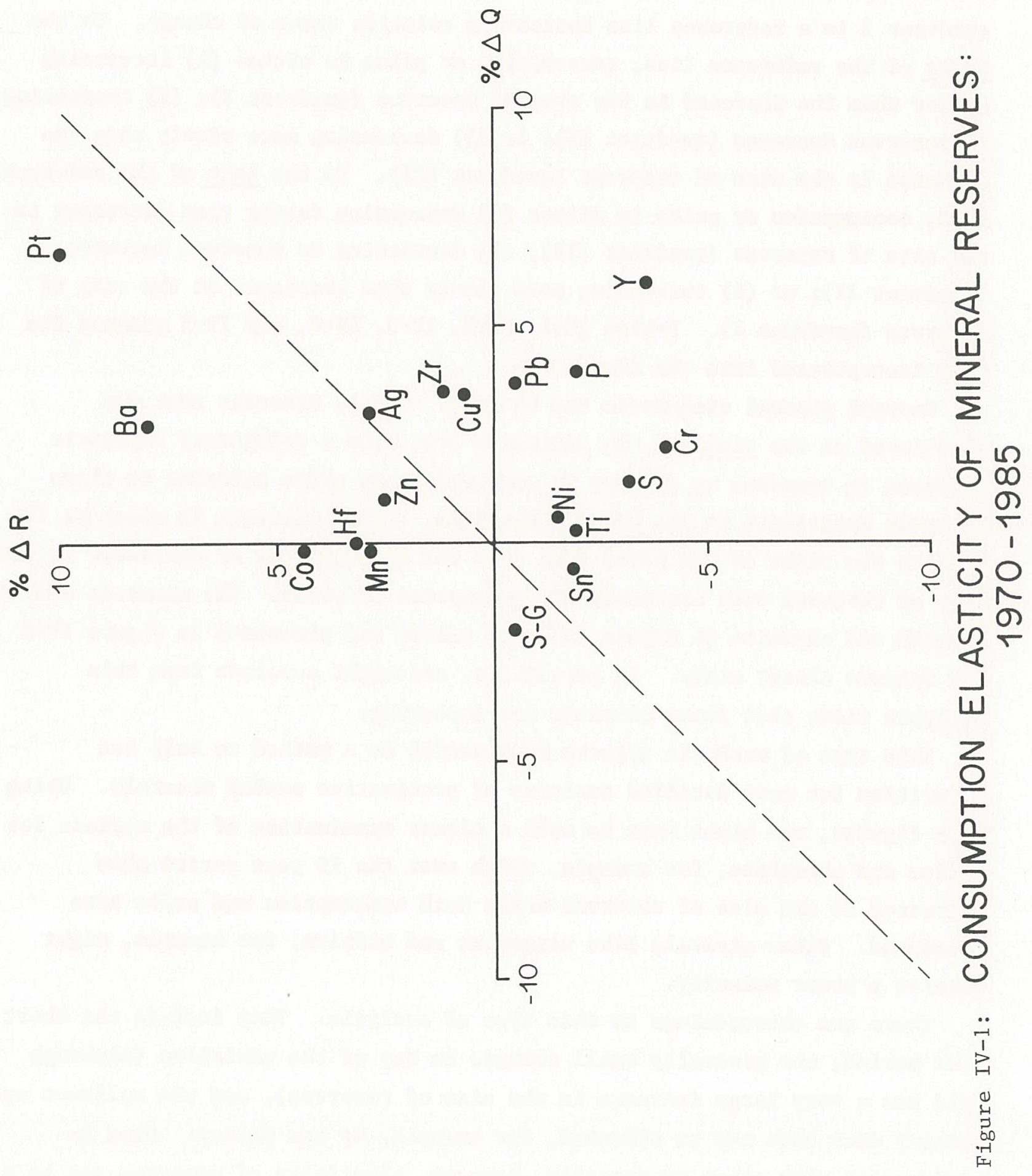




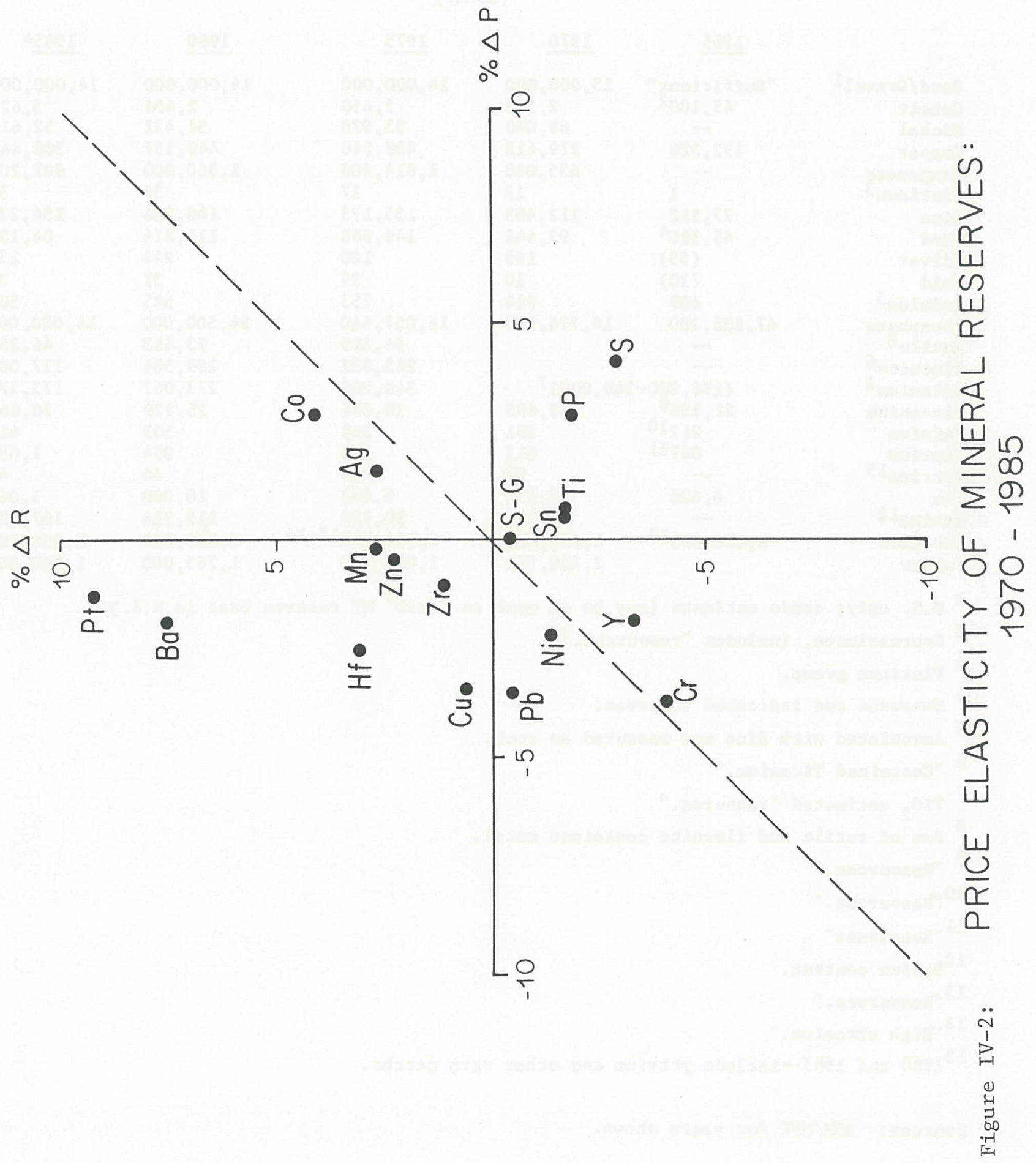


Table IV-1: WORLD RESERVES

(O0OMT)

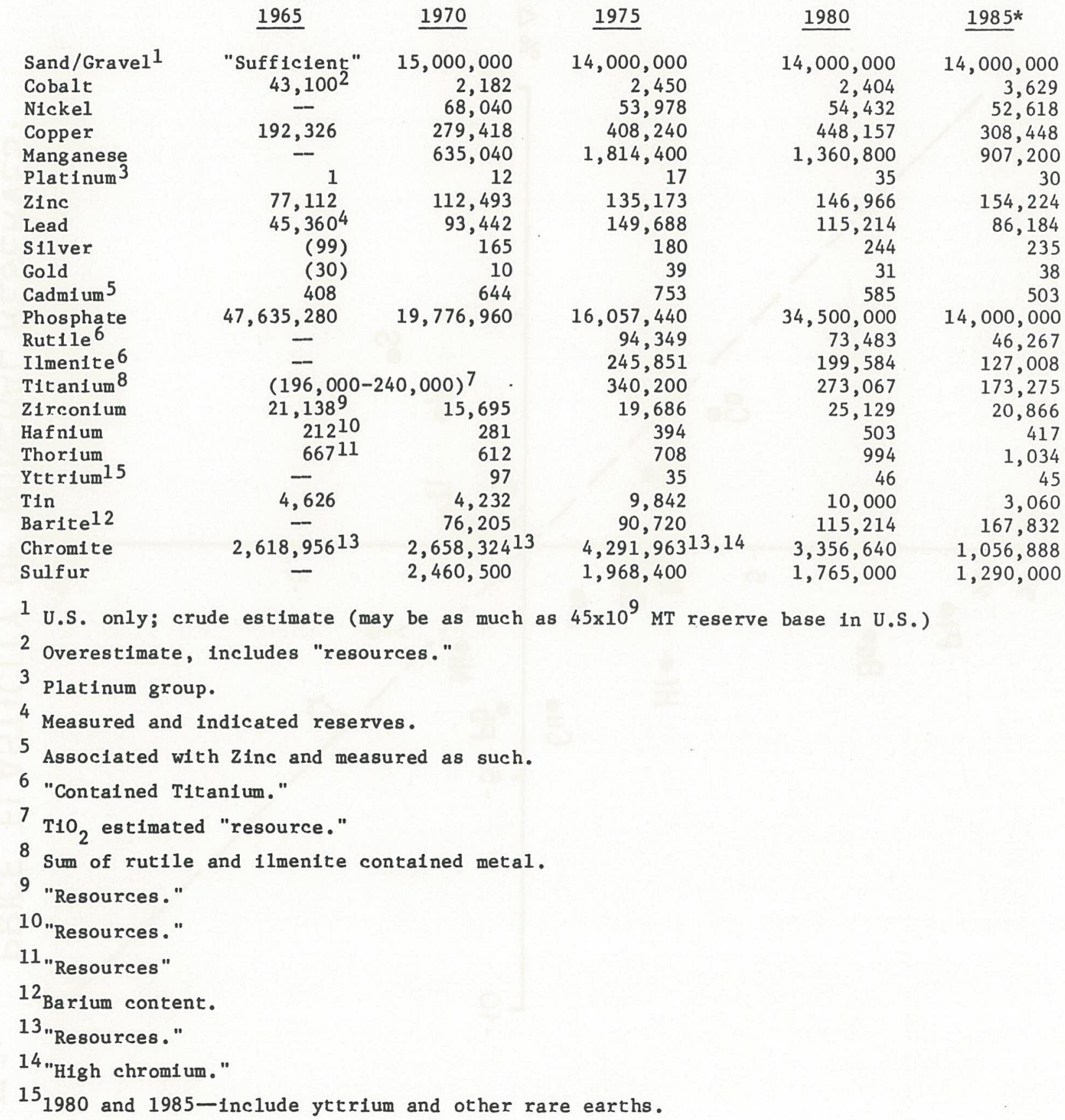

Sources: BOM/MFP for years shown. 
Table IV-2: CHANGE IN WORLD RESERVES

\begin{tabular}{|c|c|c|c|c|}
\hline & $1970-75$ & $1975-80$ & $\underline{1980-85}$ & $\begin{array}{l}1975-80 \\
\% \quad \text { CHANGE } \\
\end{array}$ \\
\hline Sand/Gravel & -0.07 & 0.00 & 0.00 & -0.41 \\
\hline Cobalt & 0.12 & -0.02 & 0.51 & +4.14 \\
\hline Nickel & -0.21 & 0.01 & -0.03 & -1.42 \\
\hline Copper & 0.46 & 0.10 & -0.31 & +0.64 \\
\hline Manganese & 1.86 & -0.25 & -0.33 & +2.67 \\
\hline P1atinum & 0.42 & 1.06 & -0.14 & +9.38 \\
\hline Zinc & 0.20 & 0.09 & 0.05 & +2.32 \\
\hline Lead & 0.60 & -0.23 & -0.25 & -0.49 \\
\hline Silver & 0.90 & 0.36 & -0.04 & +2.65 \\
\hline Gold & 2.90 & -0.21 & 0.23 & +17.50 \\
\hline Cadmium & 0.17 & -0.22 & -0.14 & -1.37 \\
\hline Phosphate & -0.18 & 1.15 & -0.59 & -1.83 \\
\hline Rutile & -- & -0.22 & -0.37 & --- \\
\hline Ilmenite & -- & -0.19 & -0.36 & -- \\
\hline Titanium & 0.42 & -0.20 & -0.37 & -1.73 \\
\hline Zirconium & -0.26 & 0.25 & 0.28 & +1.18 \\
\hline Hafnium & 0.40 & 0.28 & -0.17 & +3.03 \\
\hline Yttrium & -0.64 & 0.31 & -0.02 & -3.35 \\
\hline Tin & 1.33 & 0.02 & -0.69 & -1.73 \\
\hline Barite & 0.19 & 0.27 & 0.46 & +7.51 \\
\hline Chromite & 0.61 & -0.22 & -0.69 & -3.77 \\
\hline Sulfur & -0.20 & -0.10 & -0.27 & -2.97 \\
\hline
\end{tabular}


Table IV-3: WORLD CONSUMPTIONa

(000MT)

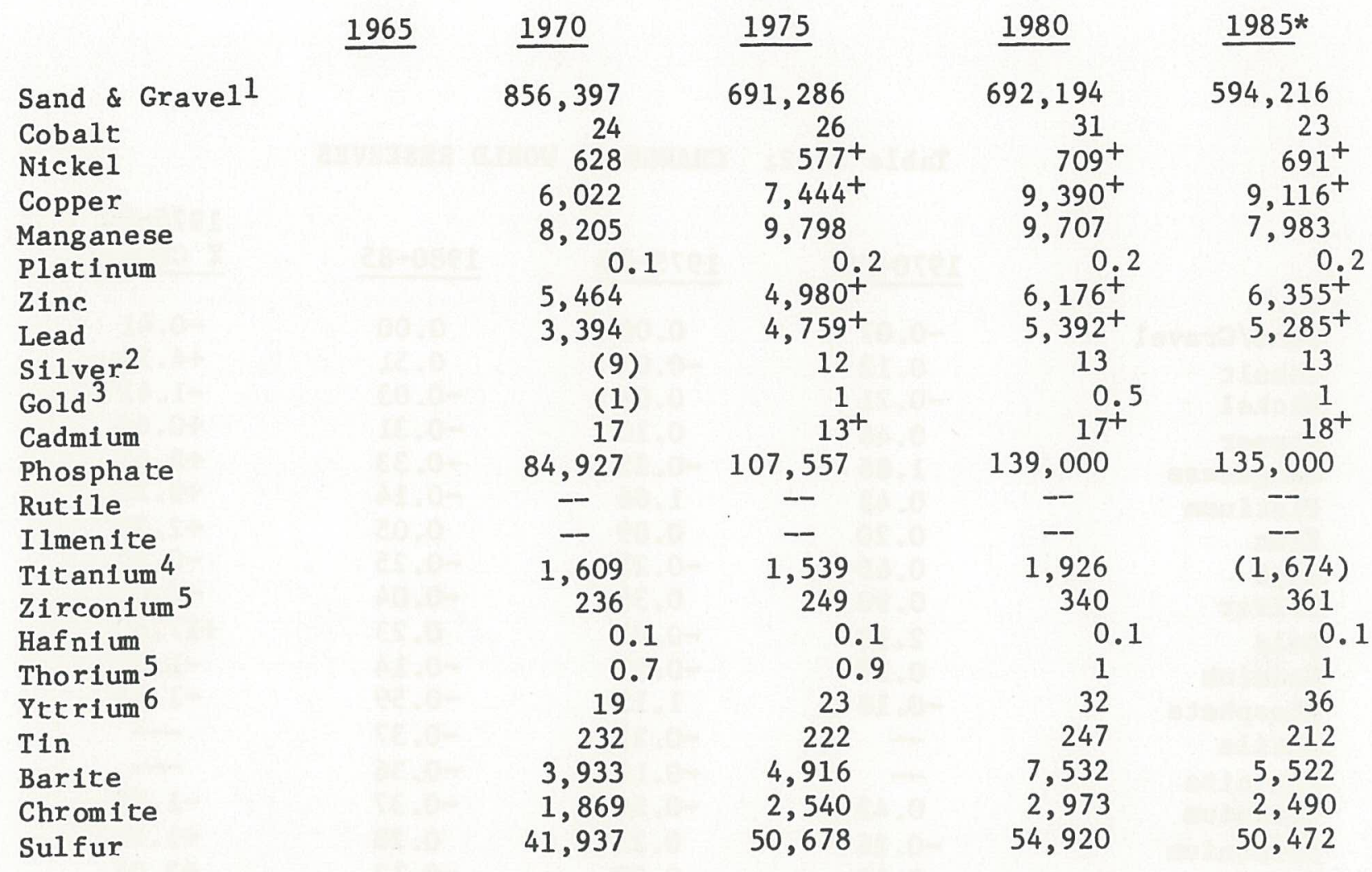

$1_{\text {U.S. production. }}$

${ }^{2}$ World comsumption data from BOM/MFP for 1975, 1979, 1983; woxld production data for 1970.

3 World "fabrication" (gross usage), Consogold (1986), Table 4, p. 37 for 1975, 1980, 1985.

${ }^{4}$ Ilmenite and rutile, metal content (1985 figure used here is actually 1982 production).

${ }^{5}$ Does not include U.S. production (proprietary).

${ }^{6}$ Yttrium and other rare earths.

a Production data used, unless otherwise noted. 
Table IV-4: CHANGE IN WORLD CONSUMPTION

Sand/Grave1

Cobalt

Nickel

Copper

Manganese

Platinum

Zinc

Lead

Silver

Gold

Cadmium

Phosphate

Rutile

Ilmenite

Titanium

Zirconium

Hafnium

Yttrium

Tin

Barite

Chromite

Sulfur
(2)

\section{0-75}

$-0.19$

0.08

$-0.08$

0.24

0.19

1.00

$-0.09$

0.40

0.33

0.00

$-0.24$

0.27

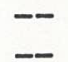

$-0.04$

0.06

0.00

0.21

$-0.04$

0.25

0.36

0.21

\section{5-80}

0.00

0.19

0.23

0.26

$-0.01$

0.00

0.24

0.13

0.08

$-0.50$

0.31

0.29

-

0.25

0.37

0.00

0.39

0.11

0.53

0.17

0.08
1980-85

$-0.14$

$-0.26$

$-0.03$

$-0.03$

$-0.18$

0.00

0.03

$-0.02$

0.00

1.00

0.06

$-0.03$

--

$-0.13$

0.06

0.00

0.13

$-0.14$

$-0.27$

$-0.16$

$-0.08$
1975-80

$\%$ CHANGE

$-1.91$

$-0.26$

$+0.63$

$+3.22$

$-0.17$

$+6.25$

$+1.02$

$+3.48$

$+2.78$

0.00

$+0.37$

$+3.68$

$+0.25$

$+3.31$

0.00

$+5.59$

$-0.53$

$+2.52$

$+2.07$

$+1.28$ 
Table IV-5: CHANGE IN WORLD PRICE

(A) (B)

$\begin{array}{cccc}\text { Ad justed1/ } & \text { Ad justedI/ } & \frac{(A-B)}{(B)} \times 100 & \begin{array}{l}\text { Units for } \\ \text { Columns }\end{array} \\ \begin{array}{c}1985 \\ \text { Price }\end{array} & 1970 & \frac{(B)}{16} & \text { (A), (B) }\end{array}$

\begin{tabular}{|c|c|c|c|c|}
\hline Phosphate & 704 & 499 & +2.57 & $/ \mathrm{MT}$ \\
\hline Tin & $1632 /$ & 150 . & +0.54 & $/ 1 b$ \\
\hline Rutile & 24 & 40 & -2.50 & $/ 1 b$ \\
\hline Titanium Metal & 124 & 113 & +0.61 & $/ 1 \mathrm{~b}$ \\
\hline Chromite & 13 & 62 & -4.93 & $\$ / \mathrm{ST}$ \\
\hline Coba1t $\underline{3} /$ & 355 & 189 & +2.93 & $/ 1 b$ \\
\hline Nicke1 & 70 & 110 & -2.27 & $/ 1 \mathrm{~b}$ \\
\hline Manganese & 44 & 46 & -0.27 & /LTU \\
\hline Copper & 22 & 50 & -3.50 & $/ 1 b$ \\
\hline Zine & 12 & 13 & -0.48 & $/ 1 \mathrm{~b}$ \\
\hline Sand/Gravel & 95 & 95 & 0.00 & $/ \mathrm{ST}$ \\
\hline Barite & 903 & 1289 & -1.88 & $/ \mathrm{ST}$ \\
\hline Platinum & 90 & 114 & -1.31 & \$/TROZ \\
\hline Hafnium & $43 \underline{4}$ & 73 & -2.57 & $\$ / 1 b$ \\
\hline Silver & 191 & 152 & +1.60 & /TROZ \\
\hline Zircon & 8341 & 100 & -1.06 & $\$ / S T$ \\
\hline Lead & 6 & 14 & -3.57 & $/ 1 b$ \\
\hline Sulfur & 33 & 20 & +4.06 & $\$ / \mathrm{MT}$ \\
\hline Yttrium5/ & 24 & 32 & -1.80 & /KG \\
\hline Gold & 99 & 31 & +13.71 & \$/TROZ \\
\hline
\end{tabular}

1/ Prices adjusted to 1967 dollars.

2/ Tin price prior to market collapse.

3/ Cathode price.

4/ 1983 prices.

5/ Monazite price (containing 55-60\% rare-earths). 
Section V: Trends in Exploration Inputs

The following tables and figures give a preliminary look at exploration effort spent toward minerals that have potential seabed sources. It should be stressed that the information represents, in most cases, inputs into the exploration and discovery process. As such it tells us little about the "effectiveness" or productivity of exploration efforts. Some studies have attempted to examine outputs or success rates for exploration effort (Rose, 1982; Quick, 1982), but no attempt is made to do so here. Although Rose found decreases in exploration effectiveness for uranium and oil over a forty year interval from 1940 to 1980, he found no decrease in exploration effectiveness for copper. He recommends the "collection of better data on expenditures for metallic mineral exploration." Rose and Eggert (1983) have examined exploration effectiveness in the United States for metals other than iron ore and uranium and have estimated increased costs of discovery by multiples of two to three (and thus lower productivity of exploration effort) during the period 1955 to 1975 .

The Exploration Survey Committee (ESC) of the Society of Economic Geologists recently has begun tabulating exploration information for minerals in the United States and Canada. Some of the results of this tabulation are combined in Table V-1. ESC estimates that the 1985 data represent only about 60 percent of exploration activities by major U.S. companies and 55 percent of exploration activities by Canadian companies. ESC (1985) concludes that: "clearly less exploration, by fewer people, is being sparingly funded by the major companies. More effort appears to be directed toward drilling at the apparent expense of traditional grand-scale multidisciplinary reconnaissance programs."

Over a longer term, Figure V-1 displays patterns in mineral exploration in North America. The United States data is from 30 mining companies, both U.S. and foreign, over the period 1961 through 1979. (Eggert, 1984). The Canadian data are from a number of Canadian government sources (the total number of companies is unknown) over the period 1961 through 1977 (Verleun, 1984). In order to complete the time series for 1978 and 1979, we estimate Canadian expenditures during those two years as an average of the relative size of Canadian expenditures to U.S. expenditures (36 percent) during the seven preceding years of 1971 to 1977. The data from 1980 through 1985 are 
taken from the composite expenditures found in Table V-1. It should be noted that the 1980-1985 data do not include expenditures made by Canadian companies in the United States or U.S. companies in Canada and, as such, may underestimate total North American exploration expenditures. Also note that before aggregation, the United States data show an increase until the 1980s, and the Canadian data show a drop in exploration expenditures during the late 1970s. The unaggregated ESC data show drops in exploration in both the United States and Canada during the 1980s. By the mid-1980s real exploration expenditures in both countries have dropped to the level of the early 1960s.

Figure V-2 displays the data accumulated on an annual basis by the Society of Exploration Geophysics on worldwide expenditures for geophysics. Geophysical data is an important component of exploration effort for hydrocarbons and is used to a lesser, but not unimportant, extent for hard minerals. The data is broken into expenditures of all types for the total world; seabed deposits of petroleum; hard minerals (including seabed deposits); seabed deposits of hard minerals; and oceanographic research. Figure V-3, a reprint from the journal "Geophysics: The Leading Edge of Exploration" 6(8): 76 (1987), displays exploration effort as measured by average number of crews per month searching for oil and gas onshore and offshore. For the field of geophysics generally, note the peak in exploration effort around 1981, measured either in expenditures or crews, followed by a rapid decline almost to the level of the early 1970s. In terms of geophysical expenditures, total exploration effort in hard minerals has seen a general long term decline since a high of $\$ 117$ million in 1968, with a short resurgence during 1975-1977. During that same period, North American exploration expenditures for metals (Figure $\mathrm{V}-1$ ) remained fairly constant. It is possible that geophysical methods assumed a less important role in exploration during the 1970s. During 1968-69, 1975-76, and 1984-85, geophysical exploration is seen in seabed hard minerals (Figure V-2). It is uncertain what minerals were being explored, although the mid-to late 1970s was the heighth of manganese nodule exploration (Figure V-4). Some recent attention has been given to the use of induced polarization as a geophysical method useful for the exploration of heavy mineral placers (Grosz, 1987; Wynn and Grosz, 1986) and marine polymetallic sulfides (Muirhead and Sternberg, 1986).

Figure V-5 displays U.S. federal government expenditures on nonliving resources from 1966 through 1986. Of particular interest is the large increase in expenditures, mostly associated with oil and gas development 
programs, in the mid- to late-1970s. These expenditures include basic scientific research as well as "resource assessment" both of which might be considered types of exploration activity. They also include administrative and management activities, such as entitlement transfers, revenue collections, and environmental impact assessment and monitoring. There is a marked decline in real expenditures since 1980, reflecting a reallocation of federal budgets as well as the lack of a "steady hand" approach to management (Broadus and Hoagland, In press).

Finally, it is interesting to refer ahead to Figures VII-1 and VII-2, which display discovery effort in MPS deposits, and to compare those figures to general trends in exploration. In particular it is noted that scientific research concerning MPS, which has elucidated some fundamental "resource" knowledge, has proceeded even during a period when private exploration efforts in metals have decreased considerably. This may be evidence of the government's steady-hand approach to science policy as an integral part of mineral resource policy. More likely, however, attention to MPS has been driven by a general phenomenon in science whereby "waves" of interest accompany startling advances on a particular problem or in a particular discipline, such as the discovery in 1977 of marine hydrothermal venting and associated massive sulfide deposits.*

*We attribute this idea of shifting efforts among scientific problems to Derek Spencer, Associate Director for Research, Woods Hole Oceanographic Institution. 
Table V-1: Combined Mineral Exploration Statistics: 1980-19851/

\begin{tabular}{|c|c|c|c|c|c|c|}
\hline$\frac{\text { Commodity Group }}{\text { (Current \$US million) }}$ & 1980 & 1981 & 1982 & 1983 & 1984 & 1985 \\
\hline Base and Precious Metals & 270 & 401 & 341 & 333 & 304 & 205 \\
\hline Other Metals & 43 & 37 & 22 & 11 & 8 & 3 \\
\hline Uranium & 146 & 82 & 47 & 33 & 25 & 9 \\
\hline Industrial Minerals & 22 & 32 & 33 & 18 & 14 & 9 \\
\hline Total & 481 & 552 & 443 & 395 & 351 & 226 \\
\hline $\begin{array}{l}\text { Number of Drill Holes } \\
\text { (thousands) }\end{array}$ & 14 & 12 & 13 & 8 & 10 & \\
\hline $\begin{array}{l}\text { Net Exploration Acres } \\
\text { (millions) }\end{array}$ & 35 & 26 & 26 & 27 & 29 & 14 \\
\hline
\end{tabular}

1/Total of United States companies' exploration in the United States plus Canadian companies' exploration in Canada.

Source: After Exploration Survey Committee (1985). 

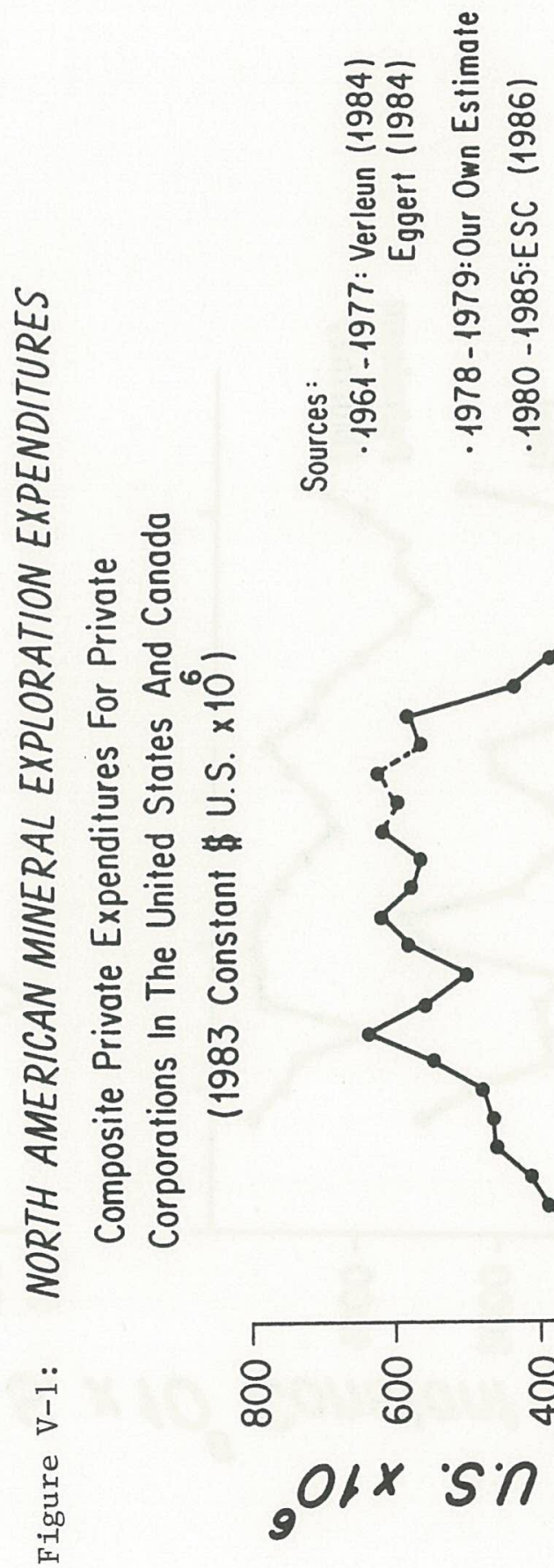

空

음

ข

눌 운

事

중유

흔 든

๗

흔

ㅇ $\infty$

는 을

जั 응

틍 응

$\gtrless$

$\ddot{\overrightarrow{1}}$

$\begin{array}{llllll}1 & 1 & 1 & \\ 0 & 8 & 8 & 8 & 2\end{array}$

${ }_{9}^{0+x} \sin \$$ 


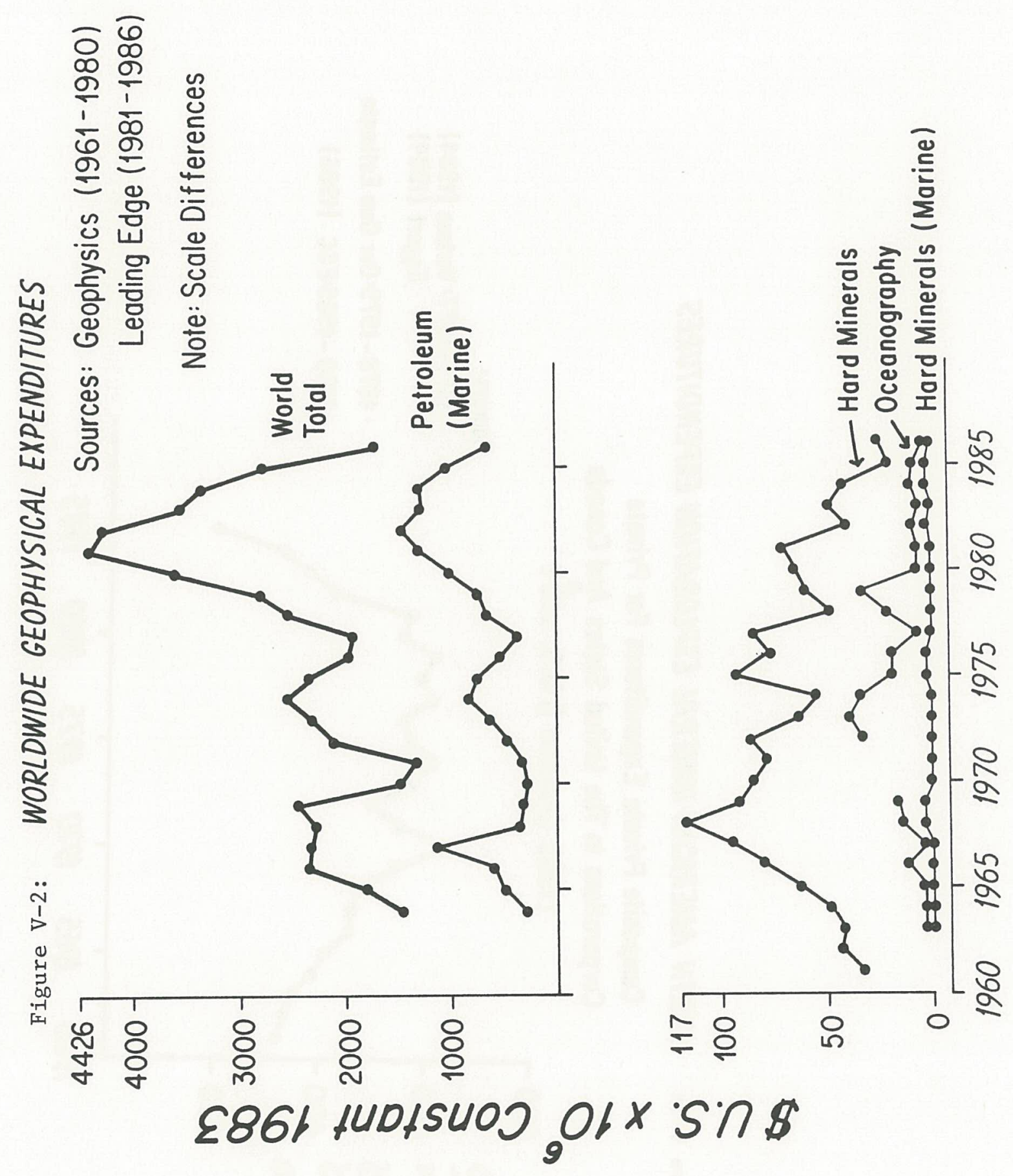




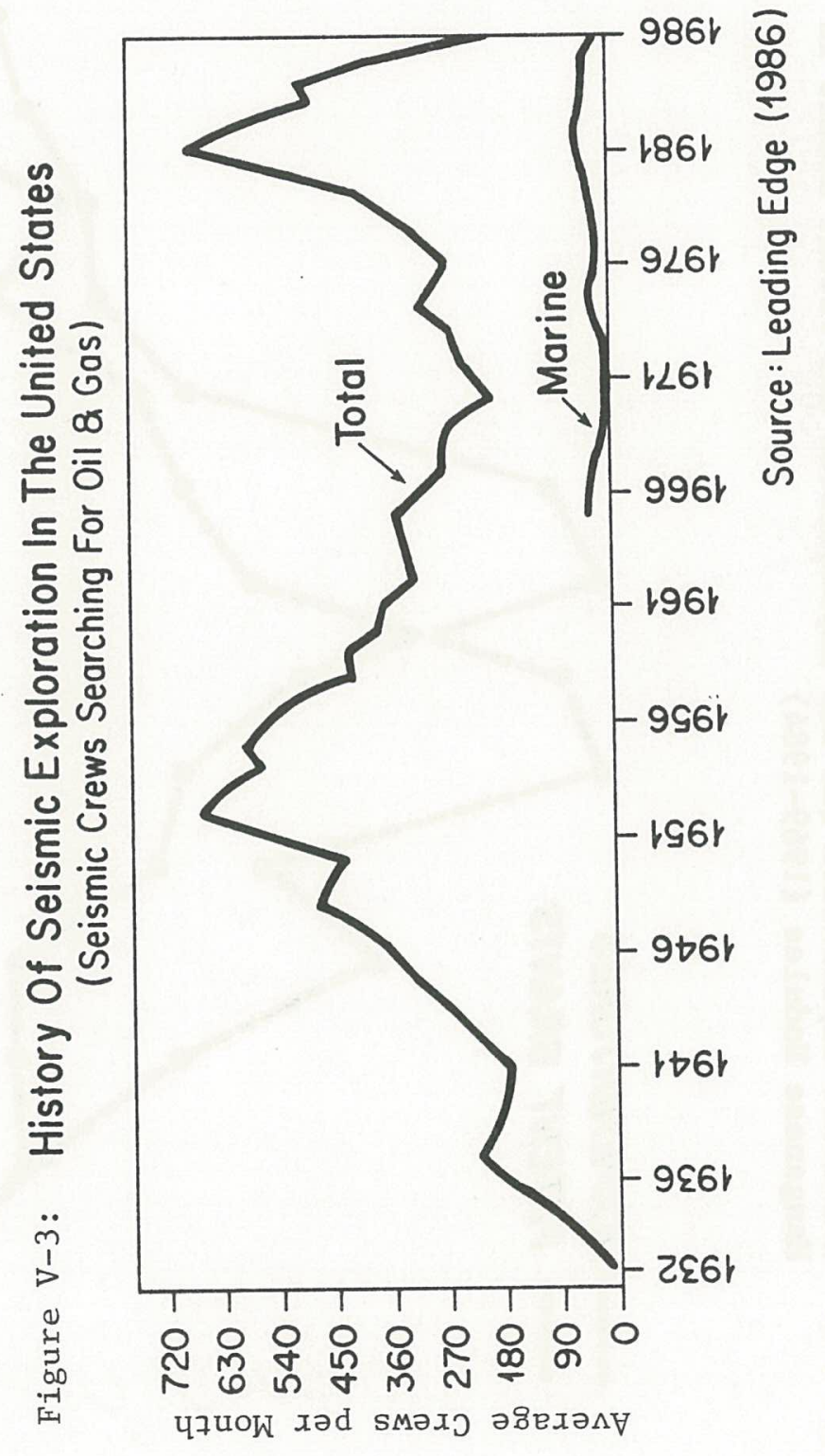




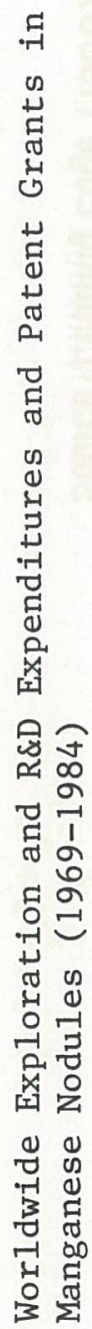

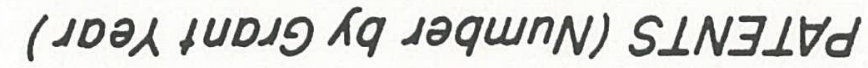
$\circ$ 요 $\circ$ 우
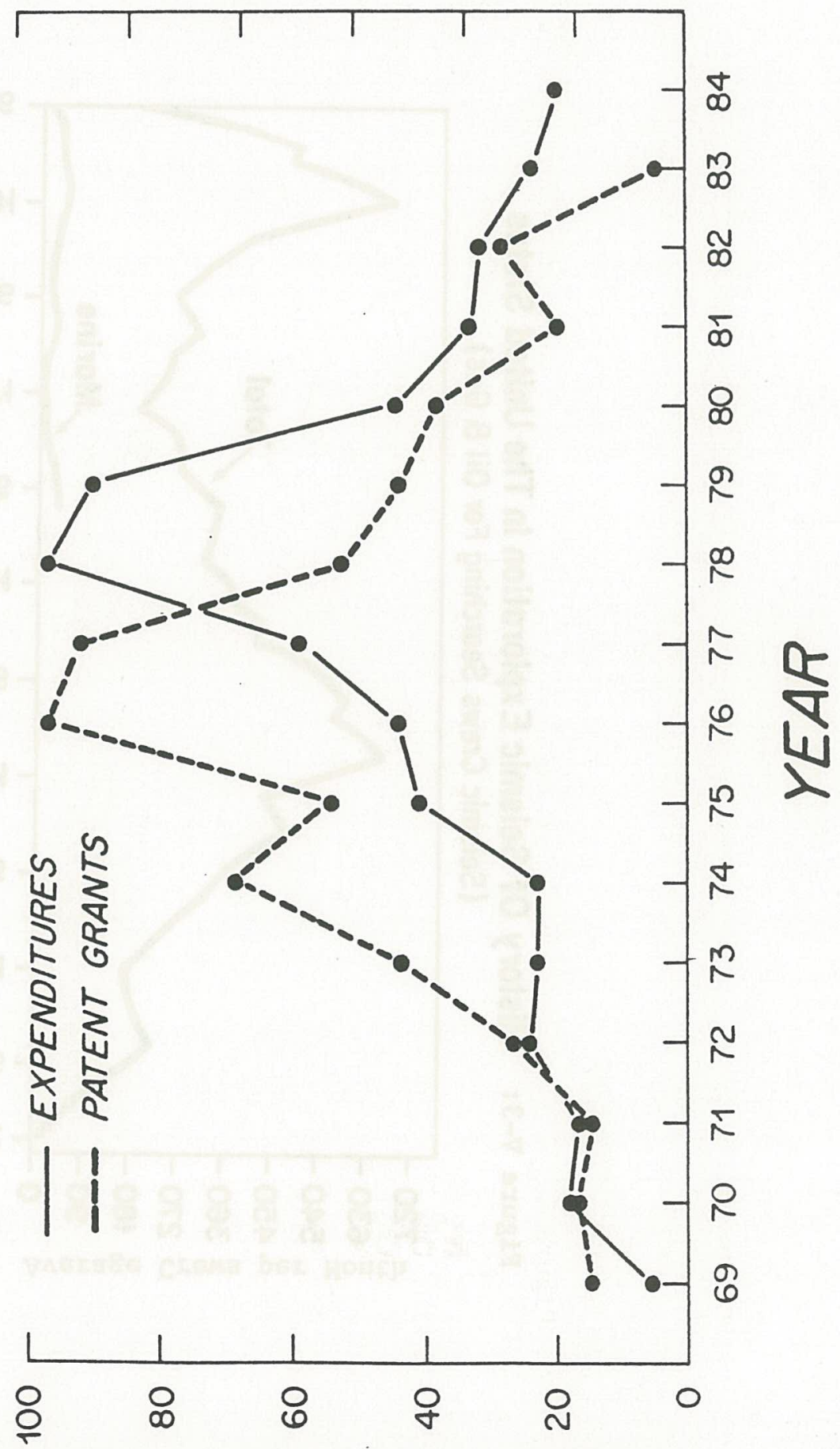


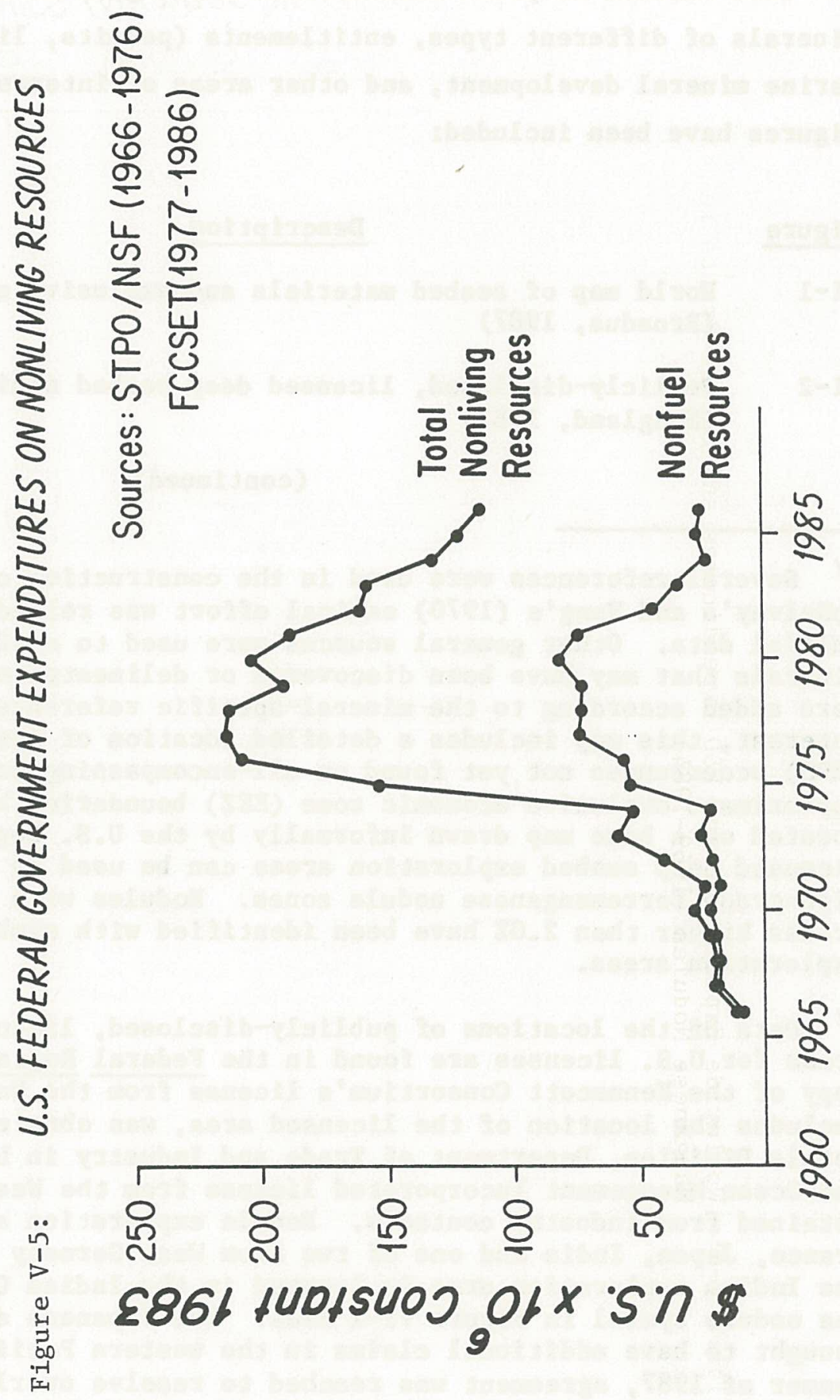


Section VI: Worldwide Locations, Entitlements, and Areas of Interest

This section compiles information on the general location of marine minerals of different types, entitlements (permits, licenses, leases) for marine mineral development, and other areas of interest. The following figures have been included:

Figure

Description

VI-1 World map of seabed materials and exclusive economic zones 1 / (Broadus, 1987)

VI-2 Publicly-disclosed, licensed deep seabed mining exploration areas 2 / (Hoagland, 1987)

(continued)

1/ Several references were used in the construction of Figure VI-1. McKelvey's and Wang's (1970) seminal effort was relied upon primarily for the initial data. Other general sources were used to confirm this early work. Minerals that may have been discovered or delineated more carefully since 1970 were added according to the mineral-specific references below. Of special interest, this map includes a detailed location of marine polymetallic sulfide (MPS) occurrences not yet found on all-encompassing maps of this type. The approximate exclusive economic zone (EEZ) boundaries have been included as located on a base map drawn informally by the U.S. Department of State. Licensed deep seabed exploration areas can be used as rough approximations for high-grade ferromanganese nodule zones. Nodules with combined nickel-copper grades higher than $2.0 \%$ have been identified with symbols outside the exploration areas.

2/ Data of the locations of publicly-disclosed, licensed deep seabed mining areas for U.S. licenses are found in the Federal Register (NOAA, 1985). A copy of the Kennecott Consortium's license from the United Kingdom, which includes the location of the licensed area, was obtained from the Minerals and Metals Division, Department of Trade and Industry in London. The location of the Ocean Management Incorporated license from the West German government was obtained from industry contacts. Nodule exploration areas under license from France, Japan, India and one of two from West Germany have not been included. The Indian exploration area is located in the Indian Ocean at roughly where the nodule symbol in Figure VI-1 lies. The Japanese and French consortia are thought to have additional claims in the western Pacific Ocean. Note: In the summer of 1987, agreement was reached to resolve overlapping claims between potential pioneer investors under the Law of the Sea Convention. This resolution must be reviewed and approved by the LOS Preparatory Commission (scheduled for late 1987). All of the U.S. exploration licenses will be affected by this rearrangement. The cartography was done by Frank Gable, Marine Policy Center, WHOI. 


\begin{tabular}{ll} 
Figure & \multicolumn{1}{c}{ Description } \\
VI-3 & $\begin{array}{l}\text { Prospecting licenses offshore New Zealand for gold placers and } \\
\text { phosphorites (Glasby, 1986) }\end{array}$ \\
VI-4 & $\begin{array}{l}\text { Mining locations offshore Southeast Asia for tin and titaniferous } \\
\text { magnetite (Morgan and Valencia, 1983) }\end{array}$ \\
VI-5 & $\begin{array}{l}\text { Proposed lease tracts for U.S. arctic sand and gravel lease sale } \\
\text { (MMS, 1983) }\end{array}$ \\
VI-6 & $\begin{array}{l}\text { Proposed lease tracts for cobalt enriched ferromanganese } \\
\text { encrustations offshore Hawaii and Johnston Island (MMS, 1987) }\end{array}$ \\
VI-7 & $\begin{array}{l}\text { Proposed lease area for marine polymetallic sulfide deposits, leased } \\
\text { tracts for phosphorites, and played-out barite deposit at Cast le }\end{array}$ \\
Island, Alaska (DOI, 1960; Thompson and Smith, 1970; MMS, 1983)
\end{tabular} VI-8 $\quad \begin{aligned} & \text { Areas of interest for marine hard minerals: U.S. Atlantic coast (MMS, } \\
& \text { 1987) }\end{aligned}$

The following references where used to construct Figures VI-1 and VI-2. The full citations may be found in the bibliography of Section $\mathrm{X}$.

GENERAL (these references include a range of mineral types and locations):

Ballard and Bischoff (1983)

Circum-Pacific Council for Energy and Mineral Resources (1984)

Clague, Bischoff and Howe11 (1984)

Dillon (1984)

Geological Survey (1979)

Hale and McLaren (1984)

Holser, Rowland and Goud (1981)

McKelvey (1986)

McKelvey and Wang (1970)

Siddiquie et a1. (1984)

AGGREGATE (sand, grave1, calcium carbonate, or she11):

Duane (1976)

Earney (1986)

Earney (1980)

Gauss et a1. (1983)

PHOSPHORITES:

Baturin (1972)

Giresse et a1. (1984)

Kat $z$ and Glasby (1979) 
HEAVY MINERALS OR PLACERS:

E1 Gemmizi (1985)

Emery and Noakes (1968)

Hill and Parker (1970)

MacDonald (1971)

Noakes (1977)

Noakes (1972)

FERROMANGANESE ENCRUSTATIONS AND NODULES:

Commeau et a1. (1984)

Cronan (1984)

Exon (1982)

Frazer and Fisk (1977)

Manheim (1986)

MARINE POLYMETALLIC SULFIDES:

Broadus (1984)

Several references in this report (see Section IV)

OTHER GEOGRAPHICAL DATA:

DOI (1960): "Phosphate Lease File" from the Pacific Region, Minerals Management Service, Los Angeles, California

Department of State (Undated): Base map with exclusive economic zones MMS (1983): Arctic Sand and Gravel lease area MMS (1983): Gorda Ridge proposed marine polymetallic sulfides lease area NOAA (1985): deep seabed exploration areas under U.S. license Turner et a1. (1977) 


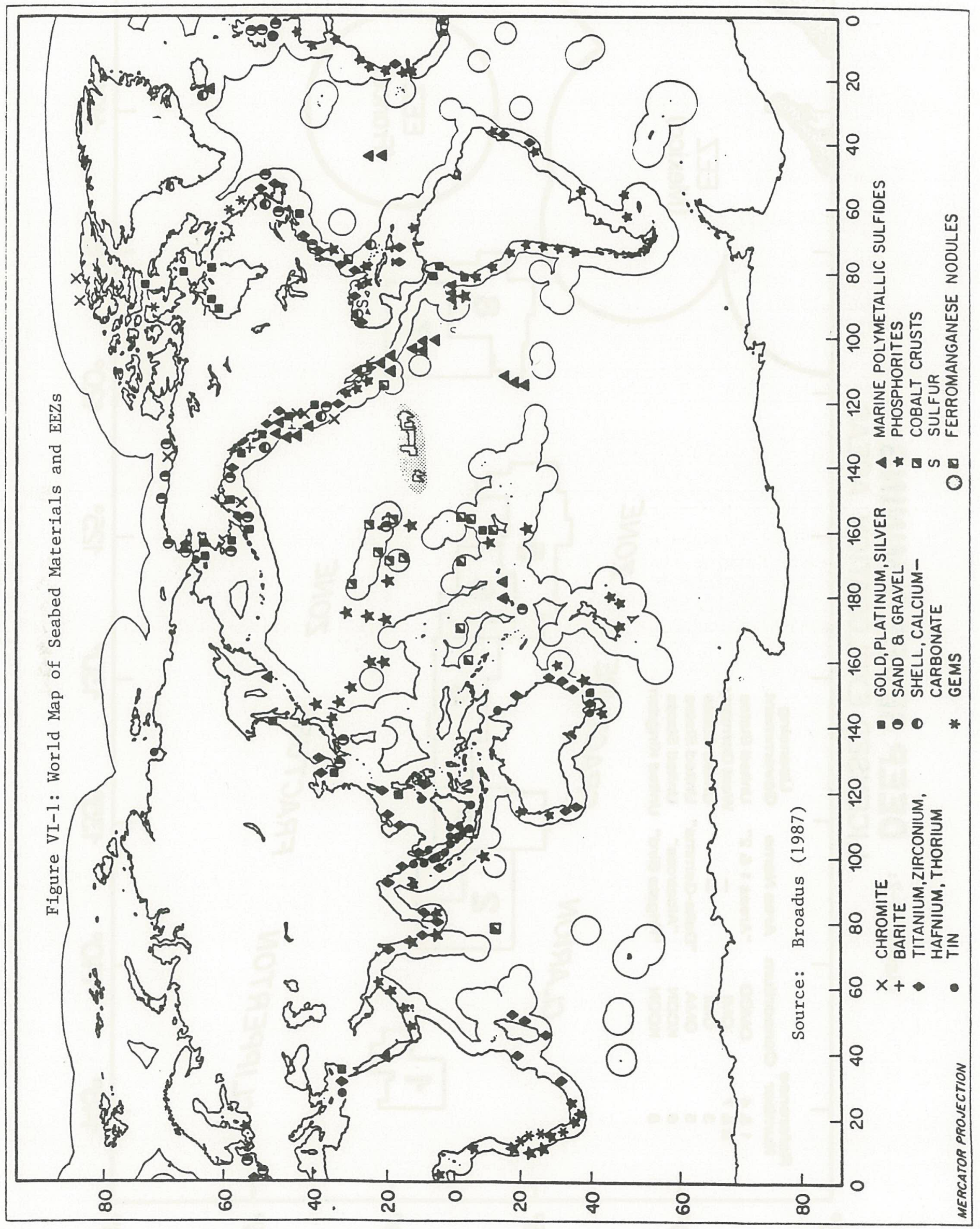




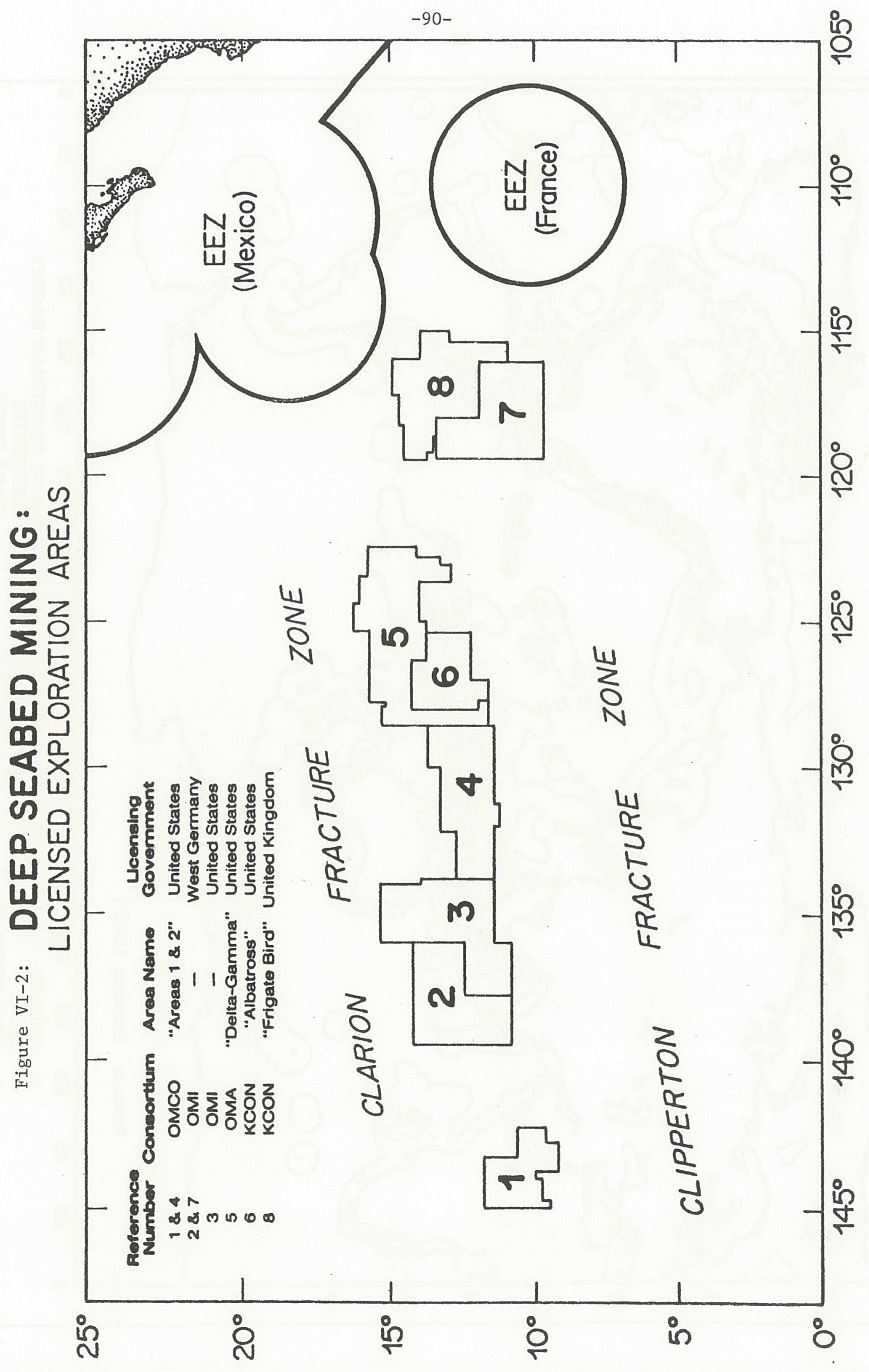


Figure VI-3

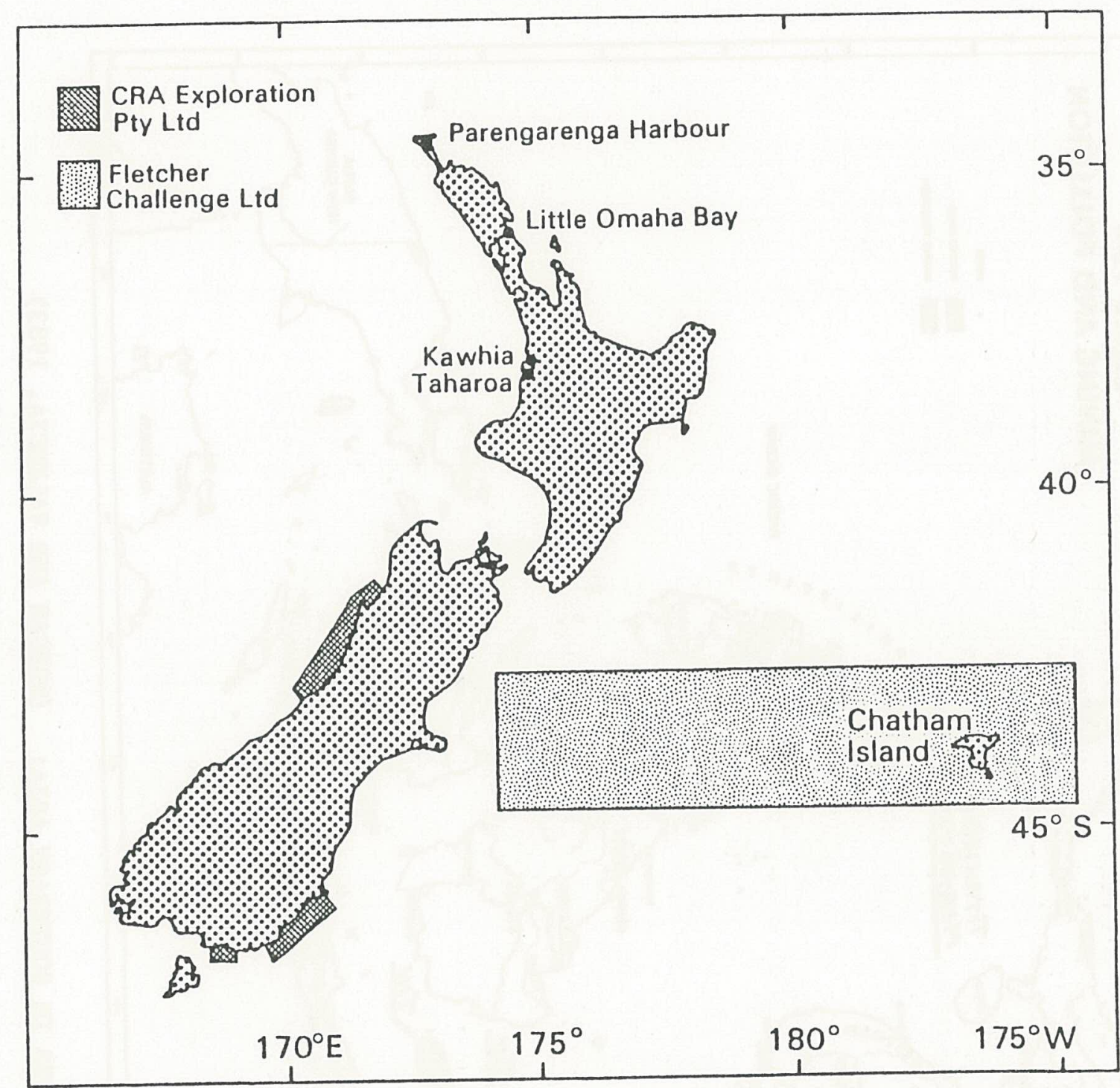

OFFSHORE PROSPECTING LICENSES IN NEW ZEALAND: (GLASBY, 1986)

- GOLD PLACERS: CRA EXPLORATION PTY. LTD.

- PHOSPHORITES: FLETCHER CHALLENGE LTD. 


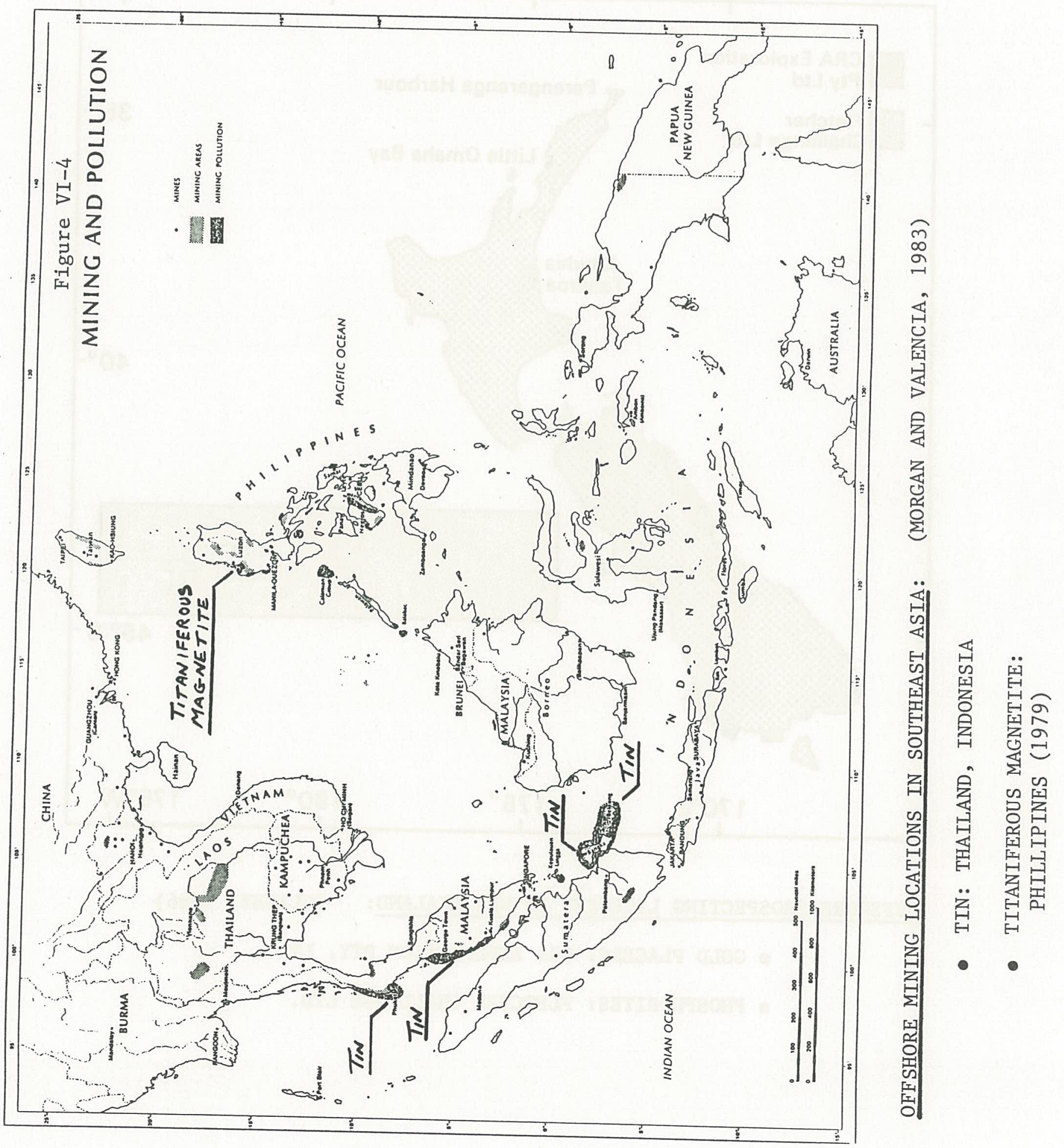




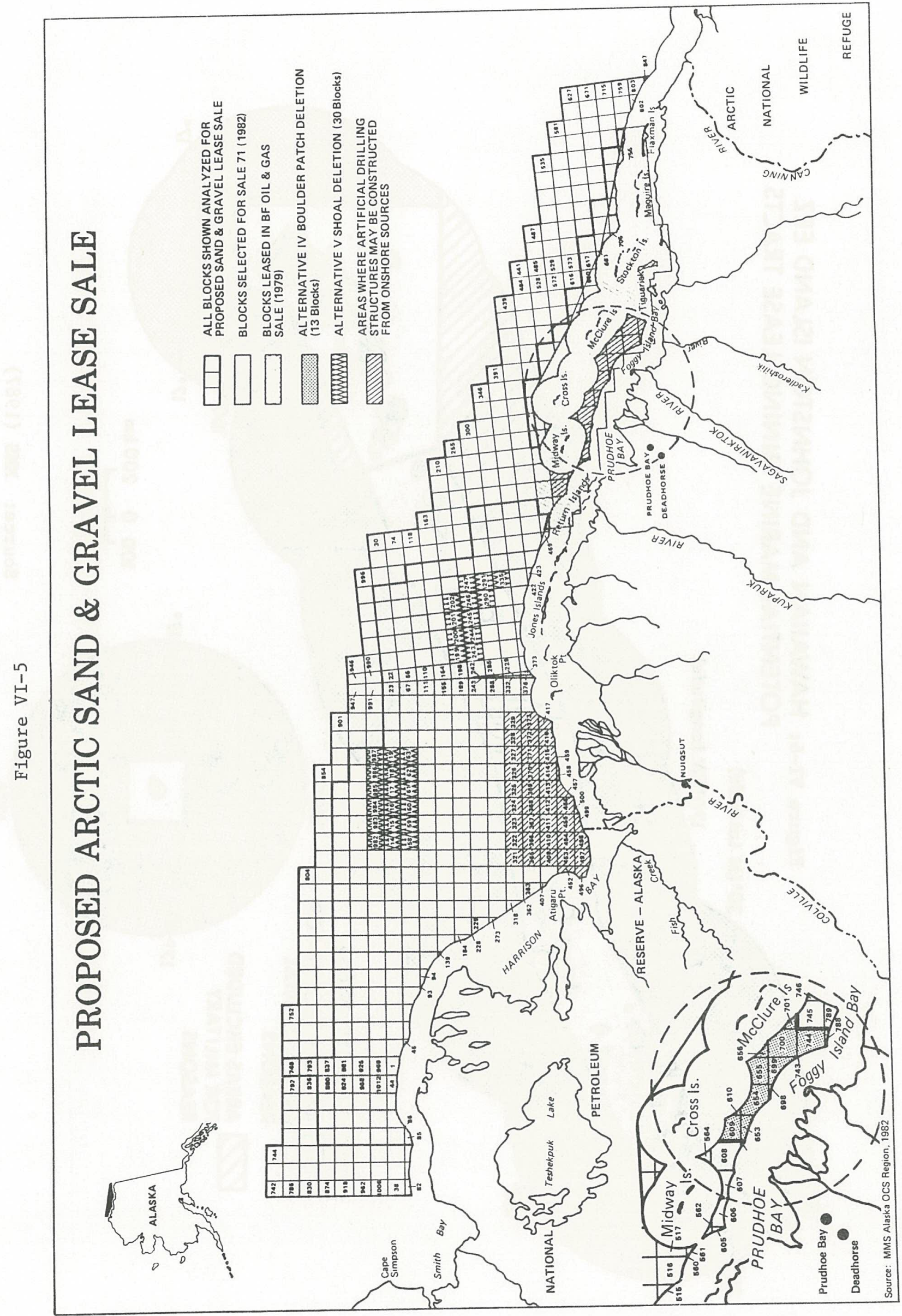




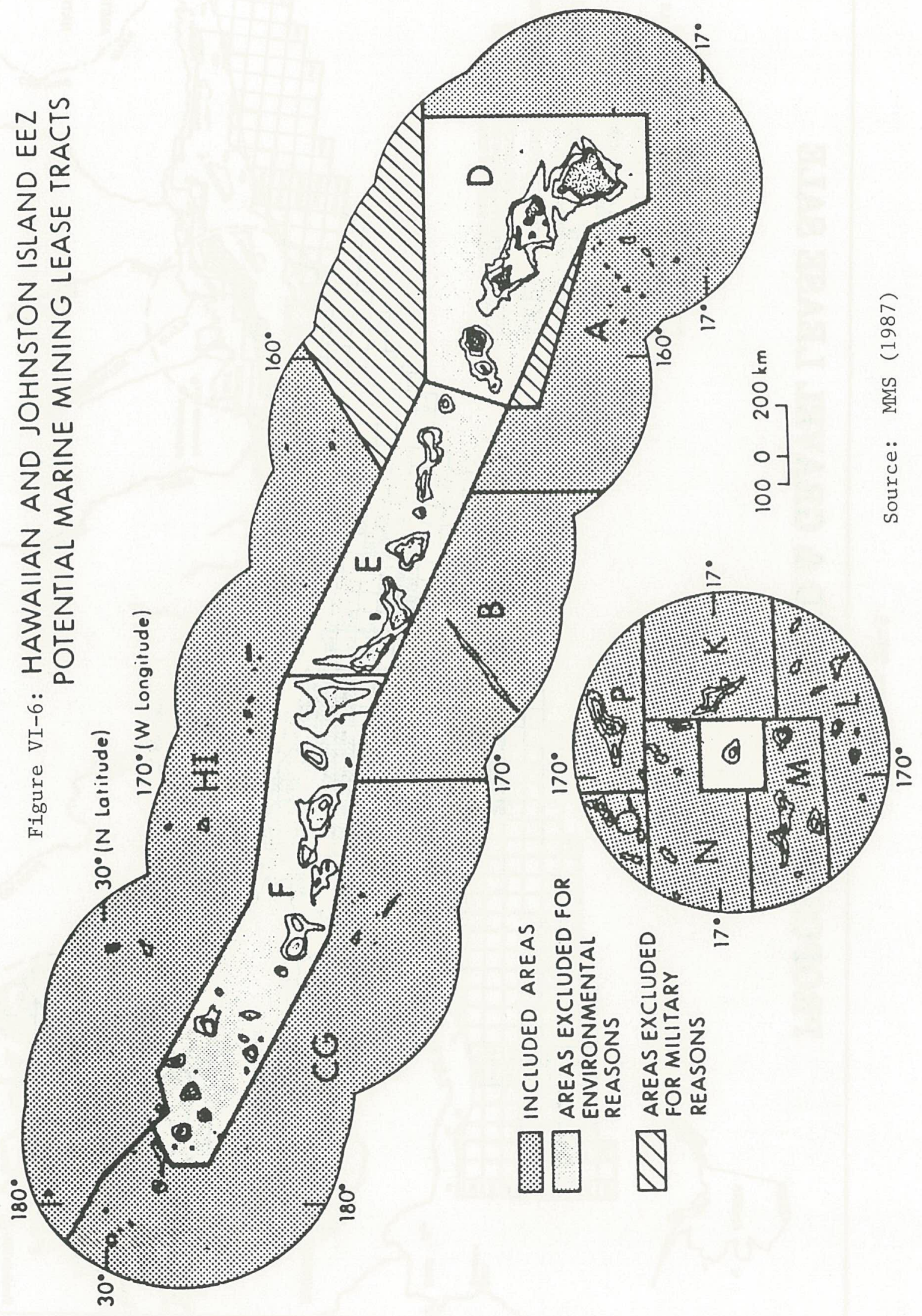


Figure VI-7: Areas of Interest for Marine Hard Minerals: U.S. Pacific Coast

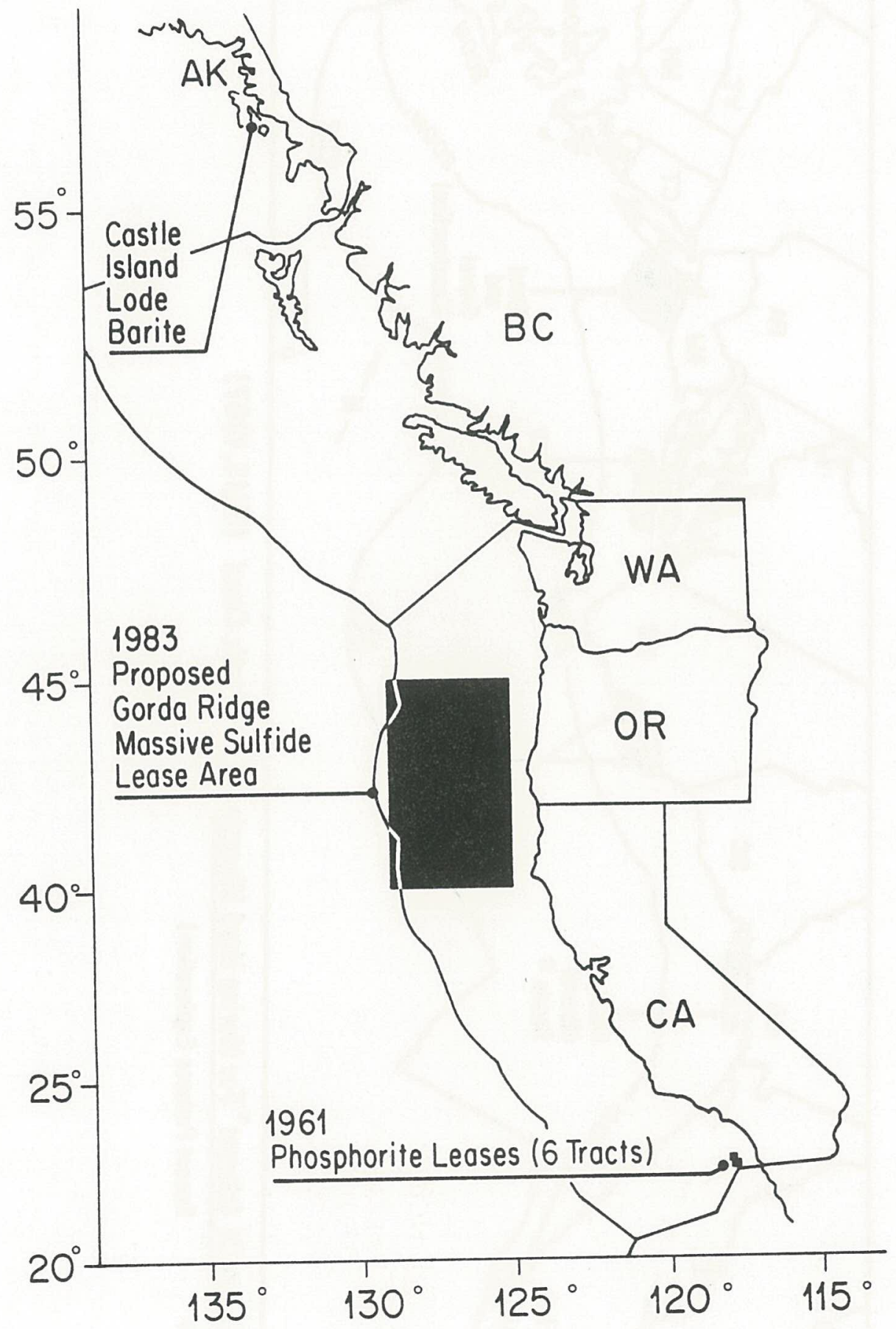

Sources: DOI, 1960; Thompson and Smith, 1970; MMS, 1983 


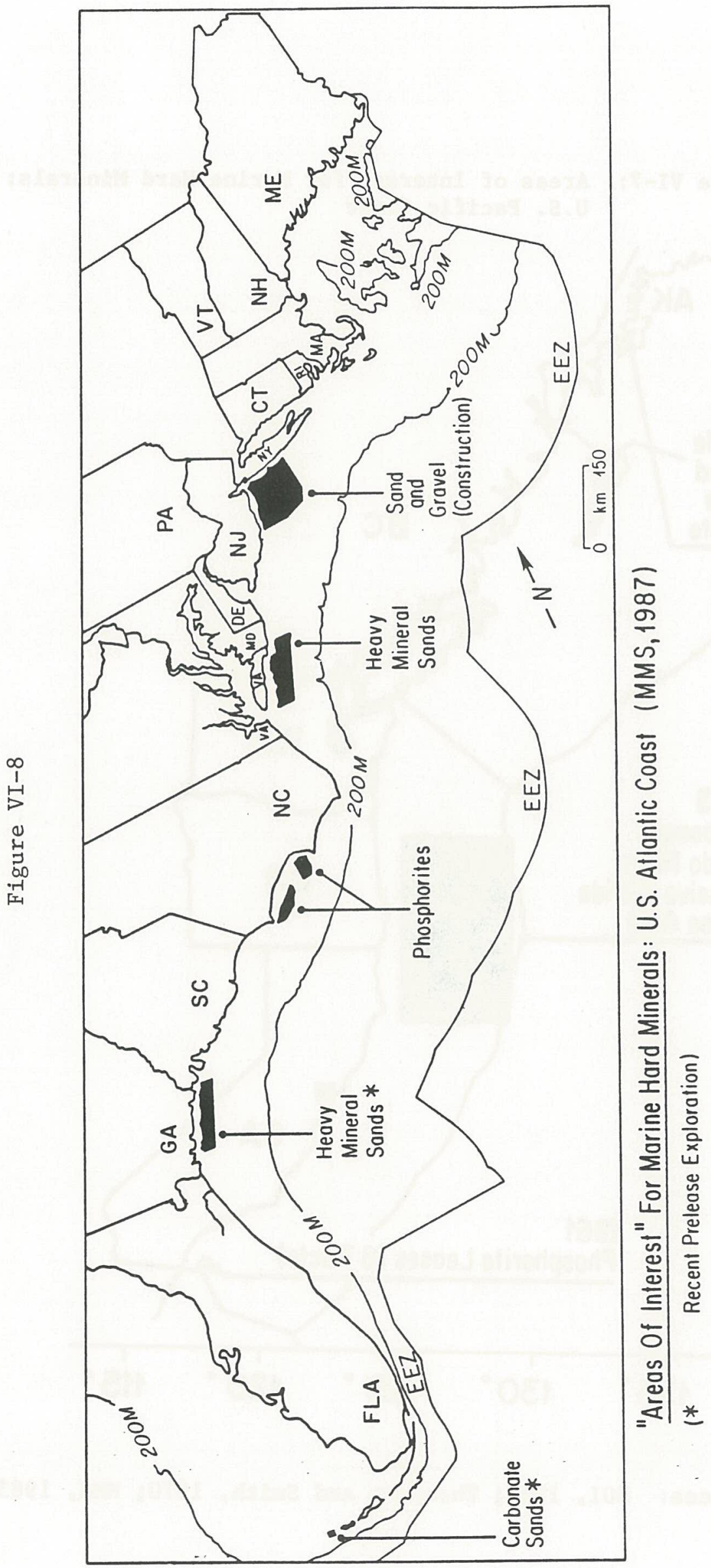


Section VII: Marine Polymetallic Sulfides:

Discovery, Location, and Generalized Composition

This section is concerned with marine polymetallic sulfides (MPS), found at oceanic crustal spreading centers. Rona (1983) gives an exhaustive summary of the potential for sulfide deposition at these centers and lists identified MPS occurrences through 1983. Bischoff et a1. (1983a) provide an excellent economic geological description of sulfide minerals. This section updates some of the previous works. The purpose of this section is to characterize generally the existing state of knowledge concerning MPS locations and to give a rough indication of the extent of scientific interest in these deposits. This section is divided into four parts: an update of submersible dive data, the jurisdictional status of MPS deposits, a record of MPS locations, and a generalized composition of MPS samples. References used in the record of MPS locations are appended to this section.

Figure VII-1 displays the annual number of locations of MPS occurrences from 1976 when the first MPS deposit was located at the Galápagos Ridge through 1986. Here the term "location" refers to a geographic location that may encompass one or more sulfide "deposits." These data were taken from Table VII-2, described below. Figure VII-1 gives a rough idea of the output of scientific discovery efforts on MPS and hydrothermal systems.

Figure VII-1:

Annual Locations* of MPS Occurrences

* (May include more than one deposit)

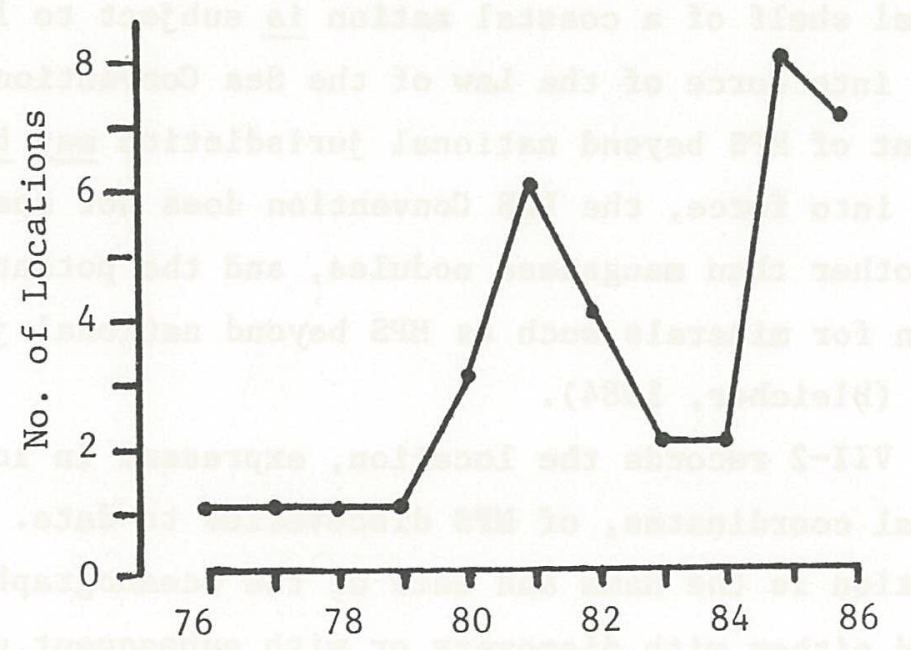


Figure VII-2 displays dive data for the Alvin submersible on hydrothermal vent locations. Dive data can be used to estimate scientific interest and activity in marine hydrothermal deposits at a general level. From 1977 to 1984, this information was compiled for dives in U.S., Canadian, and French submersibles by Jones et al. (1985). Following this work, Figure VII-2 shows dives from 1977 through 1986 for Alvin only. (In the past, the majority of dives have been conducted in Alvin.) We would like to acknowledge the assistance of Rick Chandler, Alvin Operations, WHOI, in providing this data. Since 1977, considerable effort has been devoted to scientific exploration of the world ocean ridge system. Even so, less than one percent of the ridge system has been studied in detail (Malahoff, 1985).

Thus far, MPS deposits have been located within the maritime jurisdictions of 10 countries. Table VII-1 matches locations with country and form of jurisdiction. Marine scientific research on MPS within internal waters and the territorial sea of a coastal nation is subject to local regulation. Marine scientific research on MPS located on the continental shelf or within the EEZ of a coastal nation may be subject to the "consent" and possible participation of the coastal nation. The degree to which regulation restricts or precludes marine science varies among jurisdictions (see: Ross and Landry, 1987). Beyond national jurisdiction, marine science remains unregulated. At the Preparatory Commission for the Law of the Sea (LOS) Convention, there has been some discussion concerning the distinction between marine science and "prospecting" beyond national jurisdiction, with the possible (but unlikely) result that marine science directed at geological resources like MPS might come to be regulated (Bowen, 1985). The exploration or development of MPS as a mineral resource within internal waters, the territorial sea, or on the continental shelf of a coastal nation is subject to local regulation. Until the entry into force of the Law of the Sea Convention, the exploration and development of MPS beyond national jurisdiction may be unregulated. Even with its entry into force, the LOS Convention does not speak directly to hard rock minerals other than manganese nodules, and the potential for and degree of regulation for minerals such as MPS beyond national jurisdiction remains uncertain (Bleicher, 1984).

Table VII-2 records the location, expressed in longitudinal and latitudinal coordinates, of MPS discoveries to date. Also listed along with each location is the name and date of the oceanographic expedition(s) associated either with discovery or with subsequent observation, sampling, and 
Figure VII-2: Annual ALVIN Dives on Hydrothermal Systems

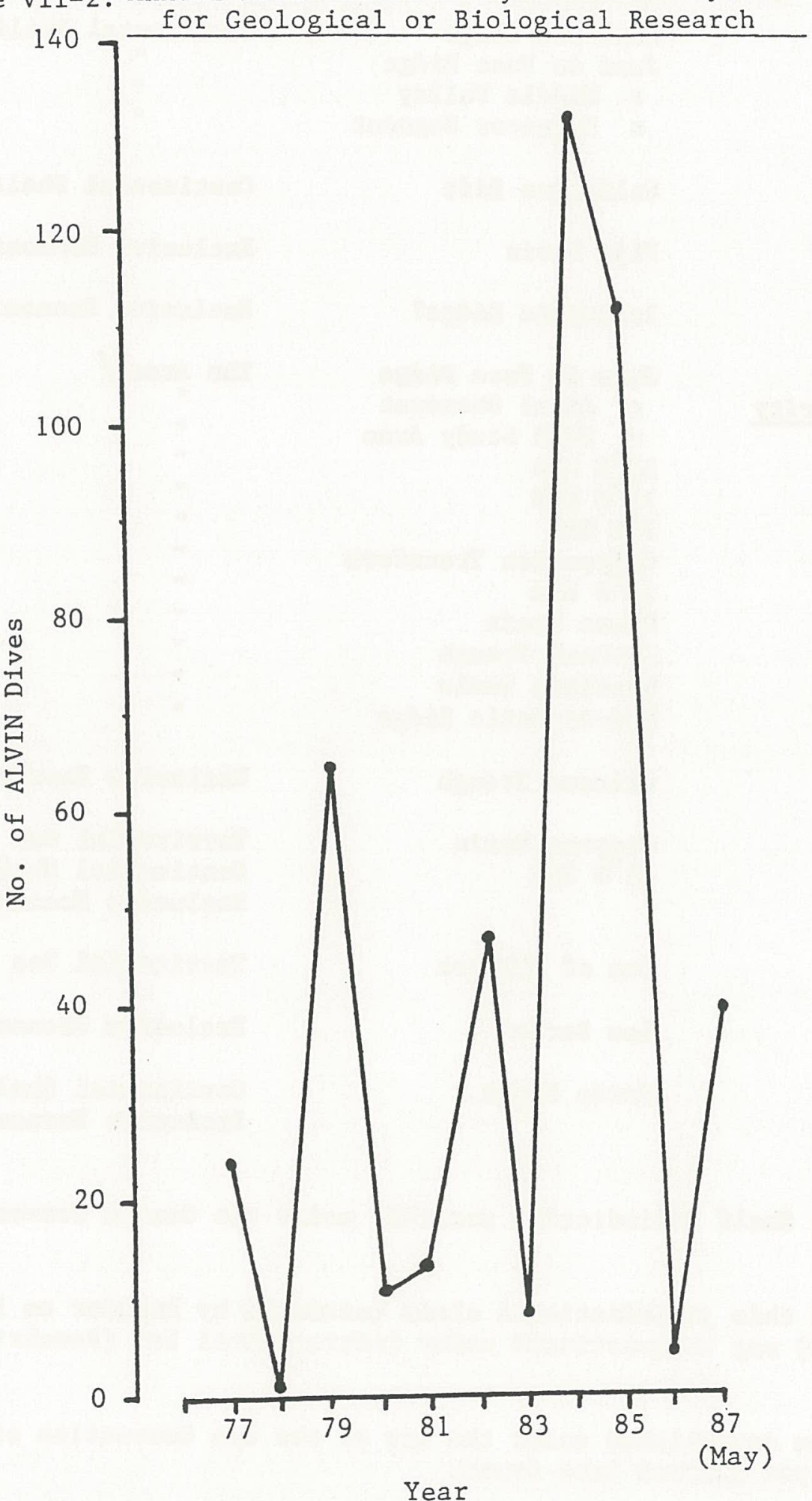


Table VII-1: Jurisdictional Status of MPS Deposits

\begin{tabular}{|c|c|c|}
\hline Country & Location & Jurisdiction \\
\hline Canada & $\begin{array}{l}\text { Explorer Ridge } \\
\text { Juan de Fuca Ridge } \\
\text { - Middle Valley } \\
\text { - Endeavor Segment }\end{array}$ & $\begin{array}{c}\text { Continental Shelf프 } \\
" ~ \\
"\end{array}$ \\
\hline Ecuador & Galápagos Rift & Continenta1 Shelf 2 / \\
\hline Fiji & Fiji Basin & Exclusive Economic Zone \\
\hline (Iceland & Icelandic Ridge? & Exclusive Economic Zone) \\
\hline$\frac{\text { International }}{\text { Seabed Authority }}$ & $\begin{array}{l}\text { Juan de Fuca Ridge } \\
- \text { Axial Seamount } \\
\text { USGS Study Area } \\
13^{\circ} \mathrm{N} \text { EPR } \\
11^{\circ} \mathrm{N} \text { EPR } \\
7^{\circ} \mathrm{N} \text { EPR } \\
\text { C1ipperton Transform } \\
20^{\circ} \mathrm{S} \text { EPR } \\
\text { Manus Basin } \\
\text { Mariana Trough } \\
\text { Woodlark Basin } \\
\text { Mid-Atlantic Ridge }\end{array}$ & $\begin{array}{c}\text { The Area } 3 / \\
\text { " } \\
\text { " } \\
\text { " } \\
\text { " } \\
\text { " } \\
\text { " } \\
\text { " }\end{array}$ \\
\hline Japan & Okinawa Trough & Exclusive Economic Zone $\underline{4}$ \\
\hline Mexico & $\begin{array}{l}\text { Guaymas Basin } \\
21^{\circ} \mathrm{N} \text { EPR }\end{array}$ & $\begin{array}{l}\text { Territorial Sea } \\
\text { Continental Shelf or } \\
\text { Exclusive Economic Zone }\end{array}$ \\
\hline Soviet Union & Sea of Okhotsk & Territorial Sea \\
\hline $\begin{array}{l}\text { Tonga } \\
\text { United States } \\
\end{array}$ & $\begin{array}{l}\text { Lau Basin } \\
\text { Gorda Ridge }\end{array}$ & $\begin{array}{l}\text { Exclusive Economic Zone } \\
\text { Continental Shelfl/ or } \\
\text { Exclusive Economic Zone }\end{array}$ \\
\hline
\end{tabular}

1/ Continental Shelf jurisdiction possible under the Geneva Convention of 1958.

2/ Strength of this jurisdictional claim (asserted by Ecuador on 19 September 1985) may be questioned under international law (Ramakrishna et al., 1986).

3/ Jurisdiction established under the Law of the Sea Convention of 1982, which has not yet entered into force.

4/ Japan is a signatory to the Law of the Sea Convention, but has not unilaterally declared either an exclusive economic zone or a claim to a continental shelf. 
experimentation. For each location, a brief description of the type of MPS occurrence, including information about water depth, number of vents, estimated deposit size and published reference source is included. This record was modeled after Rona (1983) and is simlar to, but more inclusive than, Samson (1985). We would like to acknowledge assistance in the identification of MPS locations from Tim McConachy (University of Toronto), Sarah Little (Department of Geology and Geophysics, WHOI), Cindy Van Dover (Department of Biology, WHOI), Mike Mott1 (University of Hawaii), and Geoff Thompson (Deparment of Chemistry, WHOI).

Athough 36 "locations" are recorded here in Table VII-2, there are potentially many more locations that have yet to be identified. The recent discovery of black smokers on the Mid-Atlantic Ridge, for example, greatly increased this potential, because it had been thought that such occurrences were unlikely to be found on slow-spreading ridges (Rona et al., 1986). The detection of water column signals, such as particulates or anomalous values of helium isotopes or methane, suggest that several more deposits exist at oceanic spreading centers (McConachy, 1986). Other methods of detection, such as photographic surveys (Kastens and Ryan, 1986), the remote sensing of biological communities (Van Dover et al., in press), or identification of sound frequencies (Little, S., personal communication, WHOI, 1986) increasingly may be used. Each location may actually consist of several vents or individual massive sulfide deposits. Determination of the three-dimensional size of these deposits has been hampered due to their geo-structural properties, making continuous vertical cores nearly impossible (Edmond, J., personal communication, Massachusetts Institute of Technology, 1987).

Table VII-3 tabulates "generalized compositions" of sulfide mineral samples for each location. The table allows a comparison of the compositions of sulfide minerals among locations, especially for metals of likely

industrial interest. Here, generalized compositions are averages of several samples as reported in the literature or our own average from individual samples reported in the literature. It is important to note two things about these "grade" figures. First, it is uncertain whether the sampling processes have been random. In fact, the majority of sulfide samples have been taken from vent chimneys either by dredge haul or submersible. In many cases, these samples are "high grades" and may not be truly representative of an associated 
massive sulfide deposit. Second, in most cases only a small number of samples have been analyzed. It may not be possible to consider reported compositions as statistically reliable indicators of deposit grade. Both of these points emphasize the preliminary nature of economic-geological understanding about MPS deposits and suggest that a high degree of uncertainty exists. For purposes of comparison with land based "ores" (commercially producing massive sulfide deposits), Tables VII-4 through VII-7 are reproduced from the literature for some of the well-known mines: Cyprus, Kuroko, Besshi, Brunswick, Kidd Creek, MacArthur River, and others. Care should be taken in direct comparisons of generalized compositions of MPS to the relatively better-understood, land-based massive sulfide deposits. 
Table VII-2: LOCATIONS OF MARINE POLYMETALLIC SULFIDES

Location

EXPLORER RIDGE AREA

$51^{\circ} 31^{\prime} \mathrm{N}, 130^{\circ} 53^{\prime} \mathrm{W}$

Tuzo Wils on Seamounts

$49^{\circ} 42^{\prime}-46^{\prime} \mathrm{N}$, $130^{\circ} 16^{\prime}-19^{\prime} \mathrm{W}$

"Magic Mountain

and AGOR 171"
Project and Date

U. Toronto,

U. British Columbia

September 1985

CASM 3, CASM 4, SCHISM 1

May, June, Aug 1984;

U. Toronto,

U. British Columbia May 1985
Type of Occurrence

transmissometer and conductivity anomalies suggest hydrothermal activity at foot of continental slope (Scott et a1., 1985)

60 sulfide deposits over $8 \mathrm{~km}$ ridge crest; faulted massive sulfide "lens" with Cu-rich base and Zn-rich top; southern sulfides inactive, degrading; northern sulfides inactive, but relatively intact; twelve of the 60 deposits exceed $150 \mathrm{~m}$ in length by $7-10 \mathrm{~m}$ thick; seven of the largest deposits estimated to be 1.5 million metric tons of massive sulfides; $1850 \mathrm{~m}$ depth (Tunnicliffe et al., 1986; Hannington and Scott, 1985a, 1985b; Chase et al., 1985a; Tunnicliffe et al. 1985; Scott et a1., 1985, 1984)

sulfide outcrops including one $50 \mathrm{~m}$ high by $600 \mathrm{~m}$ in diameter; seven "mounds" up to $60 \mathrm{~m}$ high by severa 1 hundred meters across; hosted by $300 \mathrm{~m}$ thick sediments; depth approx $2220 \mathrm{~m}$; relatively low concentrations of $\mathrm{Zn}, \mathrm{Cu}, \mathrm{Cd}, \mathrm{Ag}$ (but some high $\mathrm{Ba}$ ) compared to unsedimented ridge deposits elsewhere; "texturally" different from other MPS, except possibly Guaymas (Davis, 1986; Davis et al., for thcoming ) 
Location

JUAN DE FUCA RIDGE AREA $47^{\circ} 57^{\prime}-58^{\prime} \mathrm{N}, 129^{\circ} 06^{\prime} \mathrm{W}$

"Endeavor Segment"

$45^{\circ} 57^{\prime} \mathrm{N}, 130^{\circ} 02^{\prime} \mathrm{W}$

"Axia1 Seamount"

$45^{\circ} 59^{\prime} \mathrm{N}, 130^{\circ} 03^{\prime} \mathrm{W}$

"Axial Seamount,

Central Segment"

$44^{\circ} 40^{\prime} \mathrm{N}, 130^{\circ} 22^{\prime} \mathrm{W}$

"USGS Study Area"
Project and Date Type of Occurrence

MERGE October 1982; $140 \mathrm{~kg}$. of sulfides recovered; NOAA/GSC August 1984; actively venting and inactive ALVIN Expedition sulfide structures; these U. Washington 1985

ASHES Expedition 1986;

NOAA, U. Victoria CGS 1986 structures average $10-15 \mathrm{~m}$ in height, with $25 \mathrm{~m}$ the largest; groups of structures are $30 \mathrm{~m}$ long, $10-15 \mathrm{~m}$ wide; $\mathrm{Cu}-\mathrm{Fe}$ sulfides deposited by high temperature fluids; $\mathrm{Zn}$ - and Fe-rich sulfides deposited from low temperature fluids (Tivey and Delaney, 1985; Johnson and Tunnicliffe, 1985 ; Karsten et al., 1984; Hammond et a1., 1984; Kingston et al., 1983)

smal1 (100m diameter) vent field, $200 \mathrm{~m}$ from base of southeast wall of caldera; $1540 \mathrm{~m}$ depth; 4 major sulfide edifices; one clear vent (Hammond et al., 1986)

CASM I, II

June, August 1983

USGS/U. Washington

September 1981;

USGS Juan de Fuca

Study Group

Sept-Oct 1984 three sulfide/sulfate chimneys up to $25 \mathrm{~m}$ in height at $1580-92 \mathrm{~m}$ depth; $1.7 \mathrm{~m}, 160 \mathrm{~kg}$ spire recovered; samples from spire rich in $\mathrm{Zn}$; poor in $\mathrm{Cu}$; also a "field" of clear, white, and black smokers found on the west wall of caldera; some are $5 \mathrm{~m}$ high by $9 \mathrm{~m}$ in diameter (Hannington and Scott, 1987; Canadian American Seamount Expedition, 198 5, 1983)

$12 \mathrm{~kg}$ of massive sulfides dredged from one site in 1981; 1984 work showed sulfides as fields of spires and chimneys at 3 vent sites along $6 \mathrm{~km}$ segment at $2200 \mathrm{~m}$ depth; recovered sulfides typically more than 80 weight percent $\mathrm{ZnS}$; $\mathrm{Zn}$ weight percent averages $50 \%$; $\mathrm{Pb}$ up to $2 \%$ in some samples; $\mathrm{Cu}$ over $1 \%$ in four chimney samples; $\mathrm{Cd}$, Ag interesting (Philpotts et al., 1985; Normark et al., 1985, 1983, 1982; Koski et al., 1982) 
Location

GORDA RIDGE AREA $4^{\circ} 45^{\prime}-41^{\circ} \mathrm{N}, 127^{\circ} 30^{\prime} \mathrm{W}$

"Escanaba Trough: SESCA, NESCA"
Project and Date

USGS, NOAA, MMS

US Navy, OSU

June 1986;

USGS, NOAA, OSU

September 1985

US Navy

November 1977

Scripps

1980
Type of Occurrence

at least 10 sulfide occurrences in $5 \times 10 \mathrm{~km}$ area on spreading ridge axis at $3400 \mathrm{~m}$ depth; largest deposit at NESCA occurs within turbidite siltstone; outcrops may have been uplifted as much as $100 \mathrm{~m}$; no active venting, but some chimneys located; up to $43 \%$ $\mathrm{Zn}, 14 \% \mathrm{~Pb}, 5 \% \mathrm{Cu}, 680 \mathrm{ppm} \mathrm{Ag}$, and 1-2ppm Au; concurrent formation of asphaltic petroleum (Zierenberg et al., 1986; Morton et al., 1986; Koski and Kvenvolden, 1986; USGS, 1985)

hydrothermal talc deposit at $2000 \mathrm{~m}$ with pyrrhotite ( FeS) precipitated around vent (Lonsdale et al., 1980)

Kuroko-like sulfide deposits sampled from hydrothermal cones and pinnacles at "Dredge 7D," 2000m; petroliferous sulfide-rich mud; more than 100 hydrothermal deposits, $10-100 \mathrm{~m}$ in diameter; high sedimentation rate buries inactive or stagnant discharge sites (Koski et al., 1985; Kastner, 1985; Peter and Scott, 1985; Lonsdale, 1980)

massive sulfides recovered

CYAMEX: Project RITA Feb/Mar 1978 by submersible CYANA at $2625 \mathrm{~m}$ (Hekinian et al., 1980;

Francheteau et a1., 1979) 
Location

$21^{\circ} \mathrm{N}$ EAST PACIFIC RISE

$20^{\circ} 50^{\prime} \mathrm{N}, 109^{\circ} 06^{\prime} \mathrm{W}$
$20^{\circ} 48.2^{\prime} \mathrm{N}, 109^{\circ} 17^{\prime} \mathrm{W}$
"Green Volcano" or
"Volcano B"

$13^{\circ} \mathrm{N}$ EAST PACIFIC RISE

$12^{\circ} 38^{\prime}-54^{\prime} \mathrm{N}$ $103^{\circ} 49^{\prime}-104^{\circ} 01^{\prime} \mathrm{W}$

"Zone A"
Project and Date

MIT

September 1985;

Protea I 1983;

RISE Expedition

Mar-May 1979; 1981

Scripps, Washington Univ. (St. Louis), Smithsonian 1982

C1ipperton Cruise May-June 1981 "about 30" massive sulfide sites on floor of central graben--2600m depth; sulfides dredged with locally high concentrations of cobalt; sulfides more massive than any pyritic deposits dredged thus far (1981) from EPR (Hekinian et al., 1983b, 1981)

20 active hydrothermal sites located along $20 \mathrm{~km}$ ridge axis; 84 sites at $2620-40 \mathrm{~m}$ depth (possible under-estimate) of sulfide deposition found; average diameter less than $50 \mathrm{~m}$; 1argest are $80 \mathrm{~m} 1$ long by $30 \mathrm{~m}$ wide (Ballard et al., 1984; Hekinian et a1., 1984, 1983c) 
Location

$13^{\circ} \mathrm{N}$ EAST PACIFIC RISE

$123^{\prime} \mathrm{N}, 103^{\circ} 52^{\prime} \mathrm{W}$

"Seamount C" or

"Clipperton Seamount"
Project and Date May-June 1981; Cyatherm Program Jan-Mar 1982; Geocyarise Feb/Mar 1984
CNEXO/COB :

Searise Cruise Summer 1980 iron sulfides with small amounts of copper sulfide minerals, ferromanganese and other oxides dredged from 2740-2880m depth (Boulegue et a1., 1984)
Clipperton Cruise $11^{\circ} \mathrm{N}$ EAST PACIFIC RISE $11^{\circ} 30^{\prime} \mathrm{N}, 104^{\circ} \mathrm{W}$ "Zone B"

$10^{\circ} 55.6^{\prime} \mathrm{N}, 103^{\circ} 40.6^{\prime} \mathrm{W}$ "Feather Duster"
CNEXO/COB:

Cyatherm Program Jan-Mar 1981

WHO I: Protea 9 May 1984
ARGORISE Expedition December 1985
$800 \mathrm{~m}$ by $500 \mathrm{~m}$ by (3m?) marine sulfide capped with ochreous oxidation products on western limb of an apron of seamount at (2300?)-2600m depth; estimated at 2 million mt; self-potential survey indicates that sulfides might be up to $15 \mathrm{~m}$ thick in places; much hydrated silica (Hekinian et al., 1984, 1983b, 1983c)

active hydrothermal deposition and associated sulfide deposition (Ballard et a1., 1984; Hekinian et al., 1983a)

Massive sulfides (approx. $200 \mathrm{mt}$ ) associated with fissure-collapsed lava lake immediately east of axial graben; depth of $2520-25 \mathrm{~m}$; 6-8 black smokers; up to $5 \% \mathrm{Cu}$ and $40 \% \mathrm{Zn}$ (McConachy et al., 1986b, 1984; Ballard, 1984a, 1984b)

three active low-temperature vents observed by video photography from ARGO system at $2600 \mathrm{~m}$ depth; three additional vents predicted from observed distribution of brachyuran crabs (Van Dover et al., in press)

$6^{\circ} 42^{\prime}-44^{\prime} \mathrm{N}$ $102^{\circ} 36^{\prime}-38^{\prime} \mathrm{W}$ 
Location

GALAPAGOS RIFT AREA $0^{\circ} 47^{\prime}-49^{\prime} \mathrm{N}$, $86^{\circ} 04^{\prime}-13^{\prime} \mathrm{W}$

$0^{\circ} 45.3^{\prime} \mathrm{N}, 85^{\circ} 49.5 \mathrm{~W}$

"ALVIN Dive 1001"

$0^{\circ} 45^{\prime} \mathrm{N}, 85^{\circ} 50^{\prime} \mathrm{W}$
Project and Date

US Navy SASS; WHOI Angus/Alvin Programs 1976, 1977, 1979

GRAFZI Project 1980

NOAA: NOS

Aug-Sept 1981
Type of Occurrence

photographic identification of sulfide deposits $20 \mathrm{~km}$ west of Alvin Dive 1001 site at average depth of $2500 \mathrm{~m}$; some deposits associated with active hydrothermal venting (Ballard et al., 1982; Francheteau and Ballard, 1983)

visual discovery of sulfide precipitate field (inactive vents) extending $2 \mathrm{~km}$ west of dive site at depth of $2850 \mathrm{~m}$; some sulfides sampled (Malahoff et al., 1987, 1983; Embley et al., 1986; Malahoff, 1985, 1982c, 1981; Skirrow and Coleman, 1982)

4 sites of massive polymetallic sulfide deposition mapped at depth of $2600 \mathrm{~m}$ : represents "several million tons of sulfides"; largest is $1000 \mathrm{~m}$ 1ong, 35m thick, $150 \mathrm{~m}$ wide; series of mounds of coalesced chimneys up to $30 \mathrm{~m}$ high; up to $6 \% \mathrm{Cu}$ and $3 \% \mathrm{Zn}$ reported; previous1y discovered sulfides (see above) located along same fault system, approximately $2 \mathrm{~km}$ east of these discoveries (Malahoff et al., 1987; Law et al., 1981; Malahoff, 1982a, 1982b, $1982 \mathrm{c}$ )

site of recent volcanism mapped with Sea-MARC I at $2600 \mathrm{~m}$ depth on East Pacific Rise just south of Clipperton transform fault; temperature anomaly and hydrothermal communities indicate likelihood of sulfide deposit (Kastens et al., 1986) 
Location

$20^{\circ} \mathrm{S}$ EAST PACIFIC RISE

$17^{\circ} 26^{\prime} \mathrm{S}, 113^{\circ} 12.5 \mathrm{~W}$

$18^{\circ} 30^{\prime}-33^{\prime} \mathrm{S}$, $113^{\circ} 24.5^{\prime} \mathrm{W}$;

$20^{\circ} 06^{\prime}-10^{\prime} \mathrm{S}$, $113^{\circ} 42^{\prime}-44^{\prime} \mathrm{W}$

$21^{\circ} 30^{\prime} \mathrm{S}, 114^{\circ} 20^{\prime} \mathrm{W}$
Project and Date

CNEXO-COB

January 1984

CNEXO-COB

January 1984

GEOMETEP 3

March 1983

CNEXO-COB

January 1984

WHOI, Stanford, IPGP 1981

CNEXO-COB

January 1984

GEOMETEP 3

1983
Type of Occurrence

sulfide edifices discovered within drained lava ponds at $2600 \mathrm{~m}$ depth; one black smoker site; many low temperature vents (Renard et al., 1985)

4 deposits near $18^{\circ} 30^{\prime}-33^{\prime} \mathrm{S}$ at $2600 \mathrm{~m}$ depth; inactive chimney similar to $21^{\circ} 30^{\prime} \mathrm{S}$; the latter contains stockwork mineralizations as well as massive sulfides (Renard et al., 1985; Bäcker et a1., 1985; Halbach, 1984)

active high-temperature sulfide deposition fields; sulfide deposits photographed; $2850 \mathrm{~m}$ average depth of axial ridge (Renard et a1., 1985; Francheteau and Ba11ard, 1983; Ballard et al., 1981)

over a dozen active chimneys up to $30 \mathrm{~m}$ in height including black smokers; depth of $2800 \mathrm{~m}$; some edifices up to $15 \mathrm{~m}$ base diameter and $10 \mathrm{~m}$ high; sulfides sampled from blocks near bottom of graben; enriched in $\mathrm{Cu}$ (Renard et al., 1985; Bäcker et al., 1985)

Lau Basin, within EEZ of the Kingdom of Tonga; fragments from a dead black smoker were dredged from $2100 \mathrm{~m}$ depth along axial ridge; samples contain $\mathrm{Zn}, \mathrm{Fe}$, and $\mathrm{Cu}-\mathrm{Fe}$ sulfides; (Craig et al., 1987; Hawkins, 1986)

Papatua I

SIO

January 1986 ;

UCSB 1986
FIJI BASIN

$18^{\circ} 08^{\prime} \mathrm{S}, 173^{\circ} \mathrm{E}$

Papatua I: Legs 5, 6 SIO 1986 active hydrothermal vent sites identified by large methane and helium-3 plumes in North Fiji Basin along central spreading axis (Craig et al., 1987) 
Location

MANUS BASIN

$\overline{3}^{\circ} 09.7^{\prime} \mathrm{S}, 150^{\circ} 16.8^{\prime} \mathrm{E}$

MARIANA TROUGH

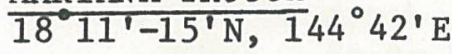

WOODLARK BASIN

$19^{\circ} 55^{\prime} \mathrm{S}, 151^{\circ} 50^{\prime} \mathrm{E}$

"Beaujolais"
Project and Date

CCOP/SOPAC

January 5, 1986
Type of Occurrence

Inactive hydrothermal chimneys photographed using Deep Tow over $150 \mathrm{~m}$ distance; masswasted chimney debris and possible sulfide-enriched sediments also seen; includes "scenic University of Hawaii photographic safari vent site" at $3^{\circ} \mathrm{S}$; no sulfides recovered in dredge sample $100 \mathrm{~m}$ from site; $2500 \mathrm{~m}$ depth; chimneys "morphologically similar" to those reported from other spreading centers (Craig et a1., 1987; Both et al., 1986; Taylor et a1., 1986)

Papatua III: Leg 9 SIO 1986; CEPHEUS Expedition 1982

off-ridge hydrothermal vents identified by methane anomalies at $3600 \mathrm{~m}$ depth; methane uncorrellated with helium-3; no evidence of hydrothermal activity at "Mounds" site to west $\left(18^{\circ} 01^{\prime} \mathrm{N}, 144^{\circ} 18^{\prime} \mathrm{E}, 3534 \mathrm{~m}\right.$ depth) from methane measurement (Horibe and Craig, 1987; Horibe et al., 1986, 1983)

PACLARK 1986

Hydrocast, CTD, transmissometer and chemical measurements and recovery of $\mathrm{Fe}-\mathrm{Mn}$ ochreous oxide crust indicate hydrothermal activity and potential new vent field (Binns et a1., 1986; McConachy et al., 1986; McConachy and Scott, 1986)

Active hydrothermal venting discovered in back-arc setting; water depth of $1540 \mathrm{~m}$; dives made in Shinkai 2000; mound discovered in summit crater of smal1 seamount; mound $5-6 \mathrm{~m}$ high, 15-25m diameter; no recognizable biological activity; chemical composition of mound different from mid ocean deposits (Uyeda, 1987; Hot ta, 1987) 
Location

SEA OF OKHOTSK

$\left(50-55^{\circ} \mathrm{N}, 155^{\circ} \mathrm{E}\right)$
Project and Date

R.V. Vulkanolog;

Vulcanology Inst of the Far Eastern Ctr. of the Soviet Acad. of Sciences

January 1986

NOAA, Cambridge U., Florida Inst. Tech. NOAA Vents Program Jul y-August 1985

WHOI, NOAA, Alvin Summer 1986; Ocean Drilling Program, Leg 106 Autumn 1985
Type of Occurrence

Hot water springs or "torches" observed on seafloor near Paramushir Island in the Kurile Island Chain (back arc basin?); active $5 \mathrm{~m}$ cone (vent?) at depth of $80 \mathrm{om}$; (Ocean Science News, 1986; Tarasov et a1., 1986)

Eleven black smokers discharging through rocks in a $150 \mathrm{~m}$ diameter area at a depth of 3620-3675m; dredge recovered $\mathrm{Cu}, \mathrm{Fe}, \mathrm{Zn}$ sulfides, sulfates, and Fe-Mn oxides and hyrdoxides from "inner mound" ( $200 \mathrm{~m}$ by $60 \mathrm{~m}$ high); possible 4.5 million mt deposit; at least 35 inactive chimneys also observed $2 \mathrm{~km}$ northeast of mound at $3600 \mathrm{~m}$ depth (Schroeder et al., 1986; Rona et al., 1986a, 1986b, 1985)

Twelve or more small chimneys up to $10 \mathrm{~m}$ high; large active black smoker more than $13 \mathrm{~m}$ high, 3-4m in diameter; 10 short holes drilled westward from smoker; minerals include $\mathrm{Zn}, \mathrm{Fe}$ sulfides at site $649 \mathrm{~b}$; $\mathrm{Cu}, \mathrm{Zn}$, and $\mathrm{Fe}$ sulfides at site $649 \mathrm{~g}$ (Sulanowski et al., 1986; Honnorez et al., 1986; Humphris, 1986)

hydrothermal activity and marine sulfide occurrences?
NR-1 Voyage

Summer 1985
ICELANDIC RIDGE ?

$\left(24^{\circ} \mathrm{W}\right.$ ?, $64^{\circ} \mathrm{N}$ ?



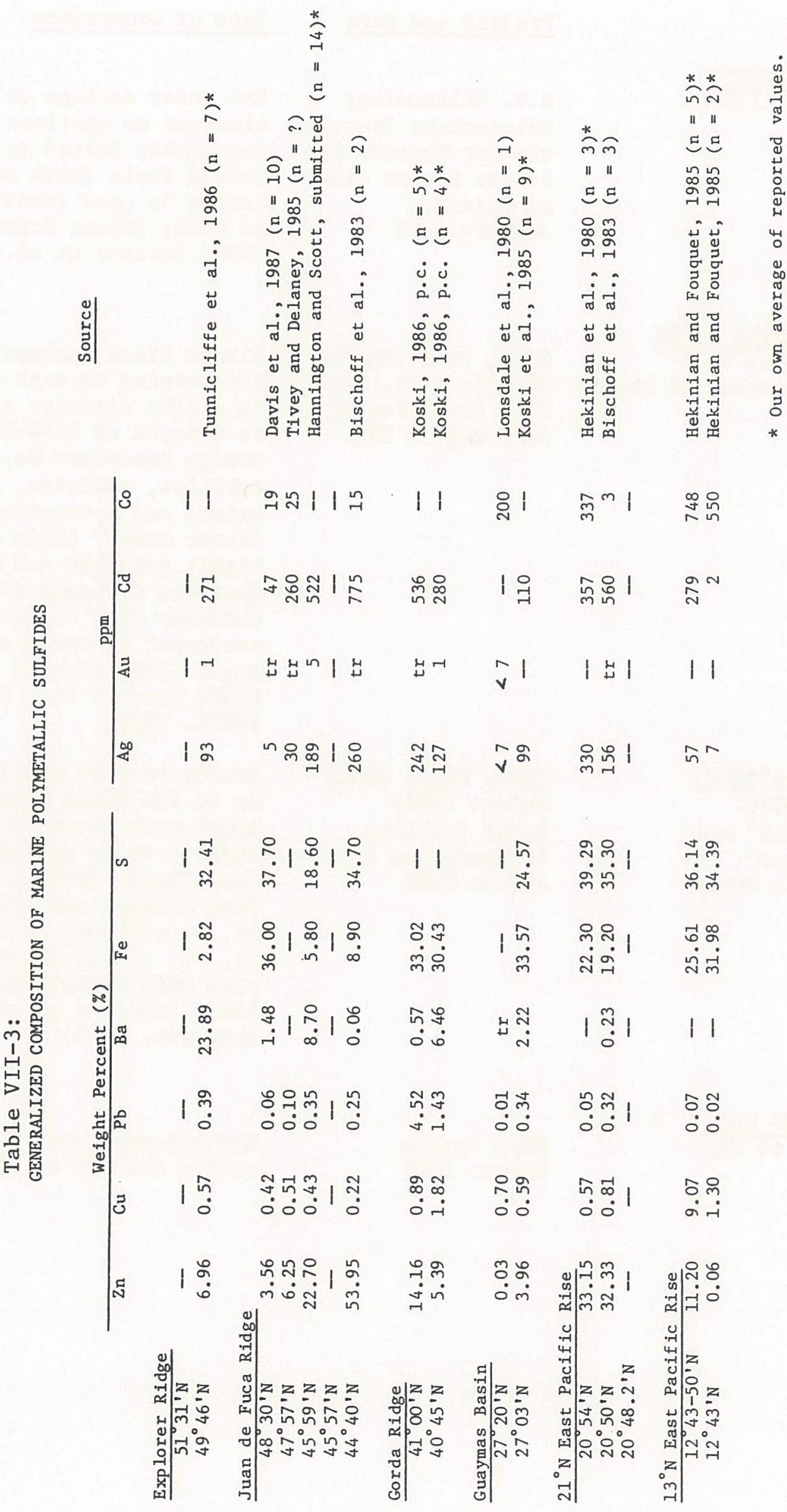

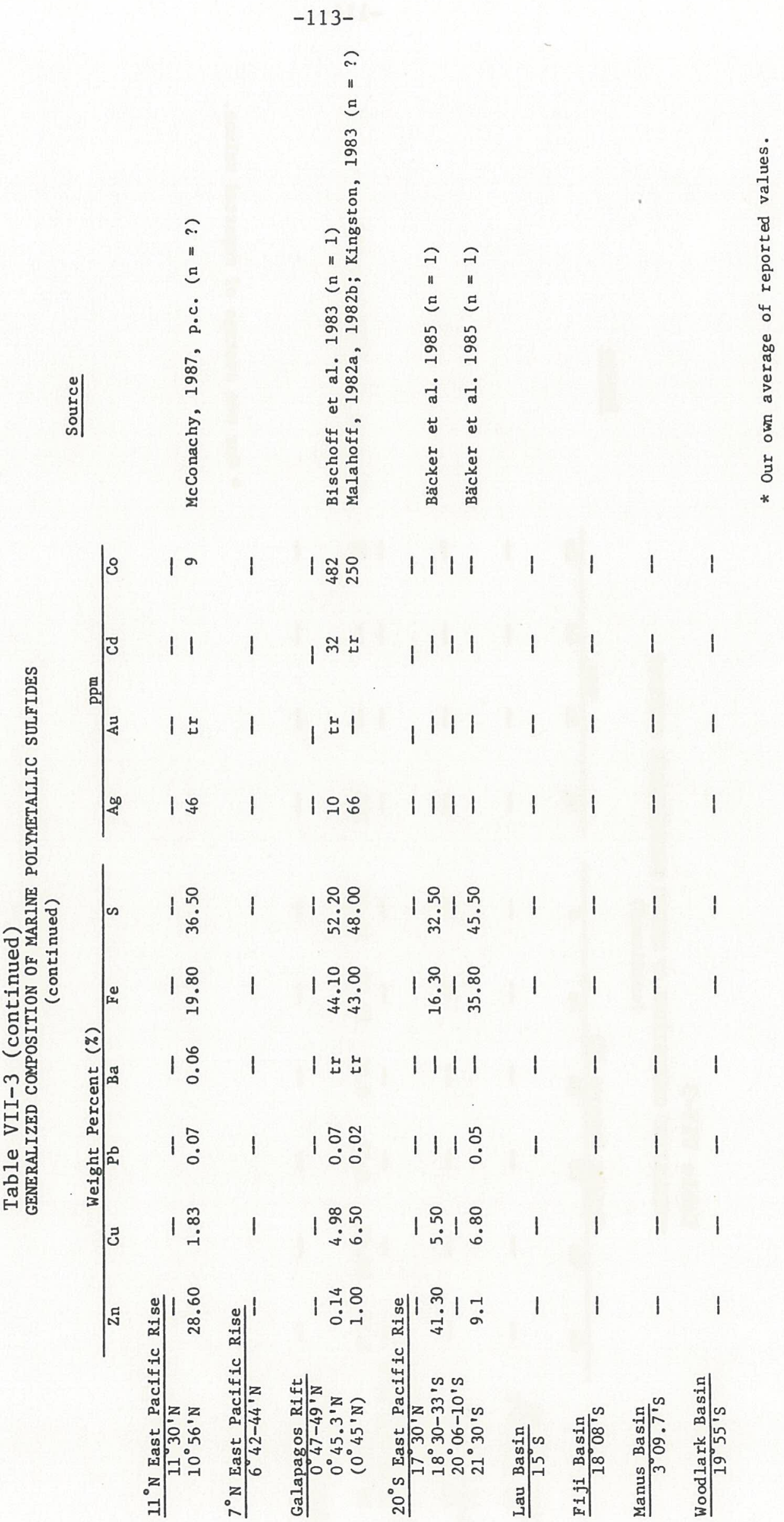


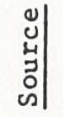

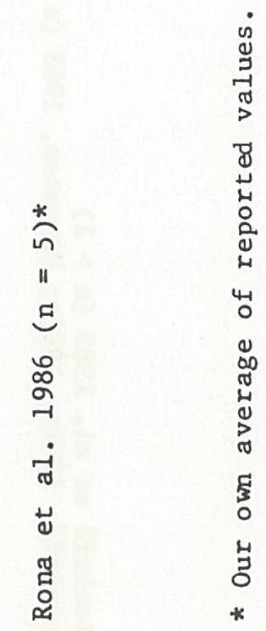

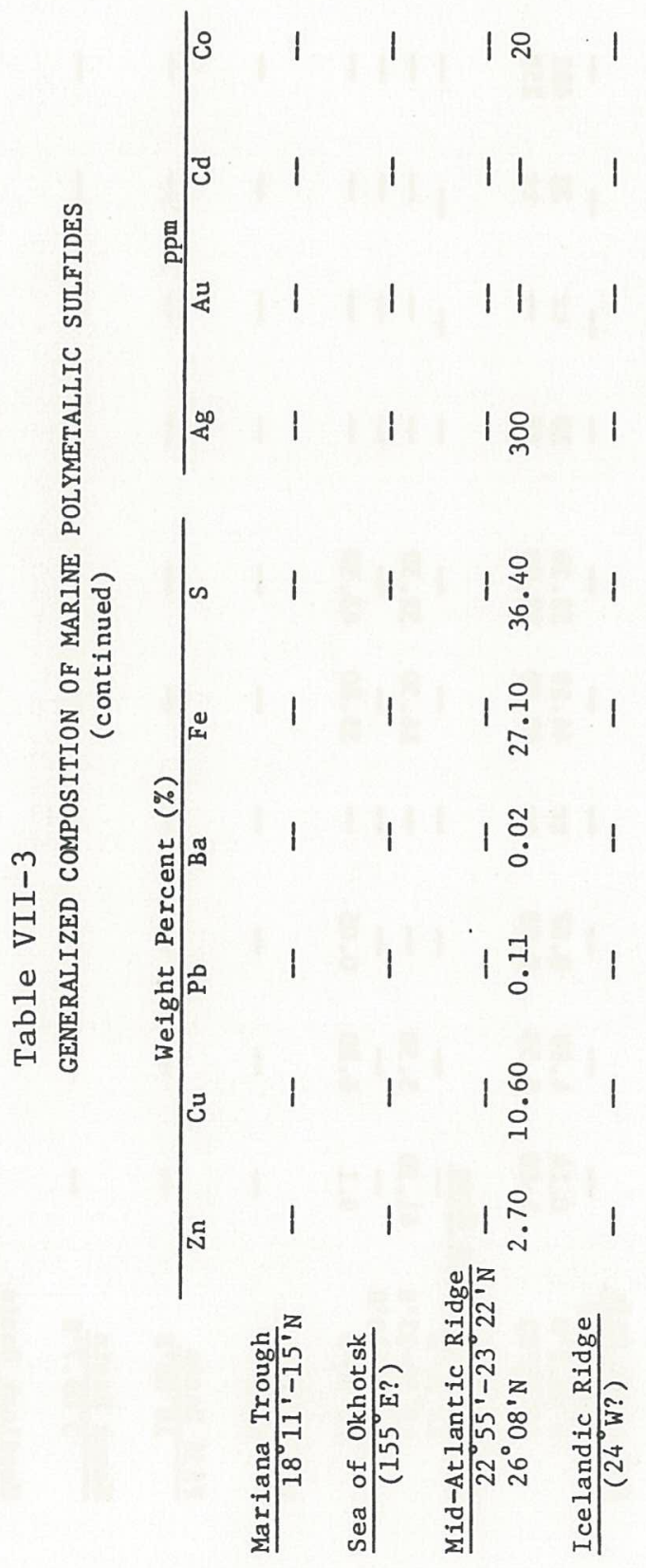


Table VII-4

TABLE 1. Distribution of $\mathrm{Cu}, \mathrm{Zn}, \mathrm{Ni}, \mathrm{S}$, and $\mathrm{Co}$ in Mathiati, Skouriotissa, Agrokipia B, and Kokkinoyia Ore Bodies

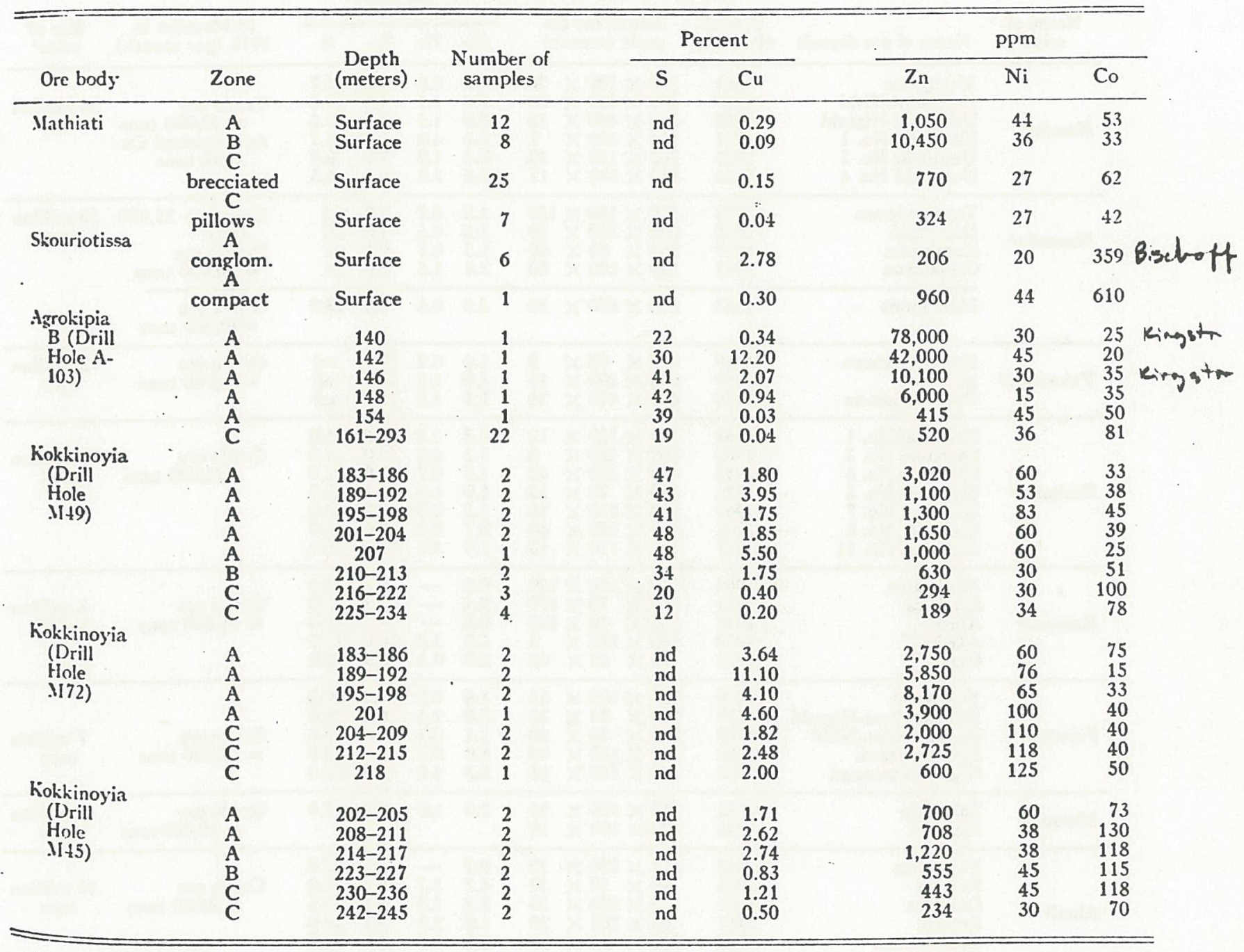

nd = not determined.

SOURCE: Constantinou, G. and Govett, G.J.S. 1973. "Geology, Geochemistry, and Genesis of Cyprus Sulfide Deposits." Economic Geology 68 (1973): 843-858. 
Table 1. Details of Kuruko Deposits in the Hokuroku District. Abbreviations: nd $=$ not determined, $-=$ low, but not analyzed. Updated from Takenchi (1970).

\begin{tabular}{|c|c|c|c|c|c|c|c|c|c|}
\hline \multirow{2}{*}{$\begin{array}{l}\text { Name of } \\
\text { mine }\end{array}$} & \multirow[b]{2}{*}{ Name of ore deposit } & \multirow{2}{*}{$\begin{array}{l}\text { Year of } \\
\text { discovery }\end{array}$} & \multirow{2}{*}{$\begin{array}{l}\text { Size of ore de- } \\
\text { posit (meters) }\end{array}$} & \multicolumn{4}{|c|}{$\begin{array}{l}\text { Grade of crude } \\
\text { ore }(\%)\end{array}$} & \multirow{2}{*}{$\begin{array}{l}\text { Production in } \\
1972 \text { (per month) }\end{array}$} & \multirow[b]{2}{*}{$\begin{array}{l}\text { Size of } \\
\text { mines }\end{array}$} \\
\hline & & & & $\mathrm{Cu}$ & $\mathbf{P b}$ & $\mathrm{Zn}_{\mathrm{n}}$ & $\mathbf{S}$ & & \\
\hline Kosaka ${ }^{1}$ & $\begin{array}{l}\text { Motoyama } \\
\text { Uchinotai-Nishi } \\
\text { Uchinotai-Higashi } \\
\text { Uwamuki No. } 1 \\
\text { Uwamuki No. } 2 \\
\text { Uwamuki No. } 4\end{array}$ & $\begin{array}{l}1861 \\
1959 \\
1960 \\
1962 \\
1965 \\
1966\end{array}$ & $\begin{array}{r}300 \times 700 \times 50 \\
400 \times 350 \times 20 \\
300 \times 400 \times 16 \\
150 \times 100 \times \quad 7 \\
200 \times 150 \times 40 \\
350 \times 100 \times 17 \\
\end{array}$ & $\begin{array}{l}2.2 \\
2.8 \\
2.0 \\
0.6 \\
0.8 \\
0.8\end{array}$ & $\begin{array}{l}0.8 \\
1.1 \\
1.5 \\
4.2 \\
1.8 \\
2.8\end{array}$ & $\begin{array}{r}4.5 \\
4.0 \\
4.4 \\
11.5 \\
7.8 \\
8.3 \\
\end{array}$ & \begin{tabular}{r|}
23.7 \\
19.8 \\
15.6 \\
4.7 \\
8.8 \\
6.3 \\
\end{tabular} & $\begin{array}{l}\text { Crude ors } \\
=\$ 5,000 \text { tons } \\
\text { Acid leached } \mathrm{Cu} \\
=70 \text { tons }\end{array}$ & $\begin{array}{l}25 \text { million } \\
\text { tons }\end{array}$ \\
\hline \multirow[t]{2}{*}{ Hanaokal } & $\begin{array}{l}\text { Tsutsumizawa } \\
\text { Doyashiki } \\
\text { Kamiyama } \\
\text { Ochiaizawa } \\
\end{array}$ & $\begin{array}{l}1885 \\
1916 \\
1919 \\
1942 \\
\end{array}$ & $\begin{array}{r}350 \times 120 \times 120 \\
600 \times 350 \times 20 \\
260 \times 60 \times 40 \\
150 \times 100 \times 30 \\
\end{array}$ & $\begin{array}{l}1.2 \\
2.5 \\
1.5 \\
2.4 \\
\end{array}$ & $\begin{array}{l}0.7 \\
0.5 \\
0.7 \\
1.5 \\
\end{array}$ & $\begin{array}{l}1.9 \\
1.8 \\
4.1 \\
5.9 \\
\end{array}$ & $\begin{array}{l}\text { nd } \\
\text { nd } \\
\text { nd } \\
\text { nd }\end{array}$ & $\begin{array}{l}\text { Cu ore }=25,000 \\
\text { tons } \\
\text { Pyritic ore } \\
=10,000 \text { tons }\end{array}$ & $\begin{array}{l}35 \text { million } \\
\text { tons }\end{array}$ \\
\hline & Matsumine & 1963 & $800 \times 800 \times 30$ & 3.2 & 0.8 & 2.5 & 23.9 & $\begin{array}{l}\text { Crude ore } \\
=50,000 \text { tons }\end{array}$ & \\
\hline Fukazawa ${ }^{1}$ & $\begin{array}{l}\text { Kanayamazawa } \\
\text { Manzaku } \\
\text { Tsunokakezawa }\end{array}$ & $\begin{array}{l}1969 \\
1969 \\
1970 \\
\end{array}$ & $\begin{array}{rr}210 \times 90 \times \quad 8 \\
190 \times 190 \times 13 \\
480 \times 400 \times 24 \\
\end{array}$ & $\begin{array}{l}1.6 \\
1.0 \\
1.1\end{array}$ & $\begin{array}{l}6.8 \\
1.5 \\
3.2 \\
\end{array}$ & $\begin{array}{l}19.0 \\
10.1 \\
15.9 \\
\end{array}$ & $\begin{array}{l}\text { nd } \\
\text { nd } \\
\text { nd }\end{array}$ & $\begin{array}{l}\text { Crude ore } \\
=10,000 \text { tons }\end{array}$ & $\begin{array}{l}8 \text { million } \\
\text { tons }\end{array}$ \\
\hline Shakanai ${ }^{2}$ & $\begin{array}{l}\text { Shakanai No. } 1 \\
\text { Shakanai No. } 3 \\
\text { Shakanai No. } 4 \\
\text { Shakanai No. } 5 \\
\text { Shakanai No. } 7 \\
\text { Shakanai No. } 8 \\
\text { Shakanai No. } 11\end{array}$ & $\begin{array}{l}1962 \\
1963 \\
1963 \\
1964 \\
1965 \\
1965 \\
1967\end{array}$ & $\begin{array}{r}300 \times 150 \times 12 \\
400 \times 120 \times 6 \\
400 \times 300 \times 40 \\
350 \times 70 \times 13 \\
350 \times 250 \times 15 \\
430 \times 170 \times 40 \\
400 \times 110 \times 10 \\
\end{array}$ & $\begin{array}{l}2.3 \\
1.1 \\
1.7 \\
1.9 \\
1.3 \\
0.7 \\
1.9\end{array}$ & $\begin{array}{l}3.2 \\
6.2 \\
0.7 \\
1.0 \\
0.9 \\
0.2 \\
3.4\end{array}$ & $\begin{array}{r}14.6 \\
10.0 \\
2.9 \\
3.4 \\
3.2 \\
1.0 \\
11.8\end{array}$ & $\begin{array}{l}14.0 \\
12.0 \\
22.0 \\
17.0 \\
26.0 \\
33.0 \\
18.0\end{array}$ & $\begin{array}{l}\text { Crude ore } \\
\quad=35,000 \text { tons }\end{array}$ & $\begin{array}{l}10 \text { million } \\
\text { tons }\end{array}$ \\
\hline Hanawa 2 & $\begin{array}{l}\text { Motoyama } \\
\text { Sandaira } \\
\text { Ajiro } \\
\text { Akedoshi } \\
\text { Osaki }\end{array}$ & $\begin{array}{r}>1960 \\
1951 \\
1957 \\
1962 \\
1965 \\
\end{array}$ & $\begin{array}{r}120 \times 100 \times 150 \\
180 \times 70 \times 190 \\
130 \times 40 \times 100 \\
650 \times 150 \times 8 \\
70 \times 30 \times \quad 45 \\
\end{array}$ & $\begin{array}{l}0.6 \\
0.4 \\
0.8 \\
1.5 \\
2.0\end{array}$ & $\begin{array}{l}\overline{-} \\
\overline{3.5} \\
0.5\end{array}$ & $\begin{array}{r}0.3 \\
0.3 \\
2.5 \\
10.0 \\
3.0 \\
\end{array}$ & $\begin{array}{l}24.0 \\
23.0 \\
15.0 \\
12.0 \\
23.0\end{array}$ & $\begin{array}{l}\text { Crude ore } \\
=11,000 \text { tons }\end{array}$ & 2 million \\
\hline Furutobe ${ }^{2}$ & $\begin{array}{l}\text { Yunosawa } \\
\text { Daikokuzawa-Higashi } \\
\text { Daikakuzawa-Nishi } \\
\text { Magariyazawa } \\
\text { Higashimatazawa }\end{array}$ & $\begin{array}{l}1959 \\
1959 \\
1960 \\
1962 \\
1968 \\
\end{array}$ & $\begin{array}{l}250 \times 100 \times 15 \\
100 \times 80 \times 20 \\
250 \times 70 \times 60 \\
200 \times 150 \times 10 \\
150 \times 150 \times 10 \\
\end{array}$ & $\begin{array}{l}1.9 \\
2.8 \\
1.1 \\
1.9 \\
2.3\end{array}$ & $\begin{array}{l}0.9 \\
1.4 \\
0.1 \\
0.3 \\
1.0\end{array}$ & $\begin{array}{l}4.3 \\
6.2 \\
1.0 \\
2.1 \\
2.9 \\
\end{array}$ & $\begin{array}{l}20.0 \\
28.0 \\
17.6 \\
20.8 \\
23.0\end{array}$ & $\begin{array}{l}\text { Crude ore } \\
=15,000 \text { tons }\end{array}$ & $\begin{array}{l}7 \text { million } \\
\text { tons }\end{array}$ \\
\hline Matsuki ${ }^{3}$ & $\begin{array}{l}\text { Takadate } \\
\text { Matsuki }\end{array}$ & $\begin{array}{l}1963 \\
196 \pm \\
\end{array}$ & $\begin{array}{r}540 \times 120 \times 10 \\
400 \times 100 \times 10 \\
\end{array}$ & 3.0 & 1.0 & 2.0 & 23.0 & $\begin{array}{l}\text { Crude ore } \\
\quad=10,000 \text { tons }\end{array}$ & $\begin{array}{c}10 \text { million } \\
\text { tons }\end{array}$ \\
\hline Ainai ${ }^{4}$ & $\begin{array}{l}\text { Yunosawa } \\
\text { Suehiro } \\
\text { Daikoku } \\
\text { Benten } \\
\text { Yokodawara } \\
\text { Hagoromo }\end{array}$ & $\begin{array}{l}1942 \\
1955 \\
1956 \\
1957 \\
1960 \\
1967\end{array}$ & $\begin{array}{r}150 \times 200 \times 50 \\
40 \times 50 \times 30 \\
80 \times 180 \times 50 \\
60 \times 200 \times 20 \\
150 \times 80 \times 20 \\
80 \times 150 \times 10\end{array}$ & $\begin{array}{l}0.7 \\
4.7 \\
2.2 \\
1.9 \\
2.0 \\
1.9\end{array}$ & $\begin{array}{l}\overline{1.7} \\
1.3 \\
1.2 \\
0.7 \\
3.5\end{array}$ & $\begin{array}{r}\overline{8.3} \\
5.1 \\
3.1 \\
2.9 \\
10.3\end{array}$ & $\begin{array}{l}25.0 \\
20.0 \\
18.5 \\
18.0 \\
21.0 \\
23.0\end{array}$ & $\begin{array}{l}\text { Crude ore } \\
\quad=9,000 \text { tons }\end{array}$ & $\begin{array}{l}10 \text { million } \\
\text { tons }\end{array}$ \\
\hline
\end{tabular}

${ }^{1}$ Dowa Mining Co.

${ }^{2}$ Nippon Mining Co.

Mitsubishi Metal Mining Co.

Nitto Metal Mining Co.

- Estimate of total crude ore mined plus reserves (from Watanabe, 1973).

- Excluding low-grade ores.

SOURCE: Lambert, I.B. and Sato, T. 1974. "The Kuroko and Associated Ore Deposits of Japan: A Review of Their Features and Metallogenesis." Economic Geology 69: 1215-1236. 
Table VII-6

Table 1. Metal contents of some massive sulfide ores

\begin{tabular}{|c|c|c|c|c|c|c|c|}
\hline Type & Location & $\% \mathrm{~Pb}$ & $\$ \mathrm{Zn}$ & $\approx \mathrm{Cu}$ & ppm $A_{E}$ & ppm Sb & ppm Bi \\
\hline \multirow[t]{7}{*}{$\begin{array}{l}\text { Archean } \mathrm{Cu}-\mathrm{Zn} \\
\text { (Canada)" }\end{array}$} & $\begin{array}{l}\text { Horne mine } \\
\text { (Noranda) }\end{array}$ & n.s & n.s & 2.19 & n.s & & \\
\hline & $\begin{array}{l}\text { Quemont } \\
\text { (Noranda) }\end{array}$ & n.s & 1.86 & 1.27 & 17 & & \\
\hline & $\begin{array}{l}\text { Mattagami Lake } \\
\text { (Matagami) }\end{array}$ & n.s & 10.4 & 0.69 & 36 & & \\
\hline & $\begin{array}{l}\text { Mattabi } \\
\text { (Sturgeon Lake) }\end{array}$ & 0.84 & 7.6 & 0.91 & 100 & & \\
\hline & $\begin{array}{l}\text { Flin Flon } \\
\text { (Manitoba) }\end{array}$ & n.s & 4.24 & 2.99 & 40 & & \\
\hline & $\begin{array}{l}\text { Fox Mine } \\
\text { (Lynn Lake) }\end{array}$ & n.s & 2.70 & 1.84 & n.s & & \\
\hline & $\begin{array}{l}\text { Kidd Creek } \\
\text { (Timmins) }\end{array}$ & 0.40 & 9.75 & 1.52 & 138 & & \\
\hline \multirow[t]{2}{*}{$\begin{array}{l}\text { Kuroko } \\
\text { (Japan) }^{b}\end{array}$} & $\begin{array}{l}\text { Kosaka and } \\
\text { Hanakoa } \\
\text { Black ore } \\
\text { Semi-black ore } \\
\text { Yellow ore } \\
\text { Pyrite ore } \\
\text { Siliceous ore }\end{array}$ & $\begin{array}{l}16.0 \\
0.6 \\
0.2 \\
0.07 \\
0.06\end{array}$ & $\begin{array}{r}22.5 \\
7.0 \\
2.0 \\
0.2 \\
0.2\end{array}$ & $\begin{array}{l}2.2 \\
4.5 \\
7.4 \\
0.4 \\
1.9\end{array}$ & $\begin{array}{r}312 \\
92 \\
36 \\
15 \\
11\end{array}$ & \multirow[t]{2}{*}{$\begin{array}{r}290 \\
60 \\
30 \\
20 \\
80\end{array}$} & \multirow[t]{2}{*}{$\begin{array}{r}20 \\
170 \\
180 \\
80 \\
140\end{array}$} \\
\hline & $\begin{array}{l}\text { Kosaka (mean) } \\
\text { Hanakoa (mean) }\end{array}$ & $\begin{array}{l}0.8 \\
0.7\end{array}$ & $\begin{array}{l}4.5 \\
1.9\end{array}$ & $\begin{array}{l}2.2 \\
1.2\end{array}$ & 95 & & \\
\hline Cyprus & $\begin{array}{l}\text { Cyprus (various) } \\
\text { Ergani, Turkey }\end{array}$ & & 0.7 & $\begin{array}{l}2.7 \\
10\end{array}$ & 22 & & \\
\hline Besshi $^{c}$ & Besshi, Japan & & 0.92 & 10 & 30 & & \\
\hline $\begin{array}{l}\text { Not specified } \\
\text { (Precambrian } \\
\text { Australia) }\end{array}$ & $\begin{array}{l}\text { McArthur River } \\
\text { Broken Hill } \\
\text { Mount Isa } \\
\text { Hilton }\end{array}$ & $\begin{array}{c}4 \\
12 \\
7.8 \\
7.7\end{array}$ & $\begin{array}{c}10 \\
4 \\
60 \\
9.6\end{array}$ & 0.2 & $\begin{array}{r}45 \\
115 \\
130 \\
125\end{array}$ & & \\
\hline
\end{tabular}

- Sangster and Scott, 1976

- Lambert and Sato, 1974

- Mercer, 1976

d Lambert, 1976

SOURCE: Amcoff, O. 1984. "Distribution of Silver in Massive Sulfide Ores." Mineralium Deposita 19: 63-69. 


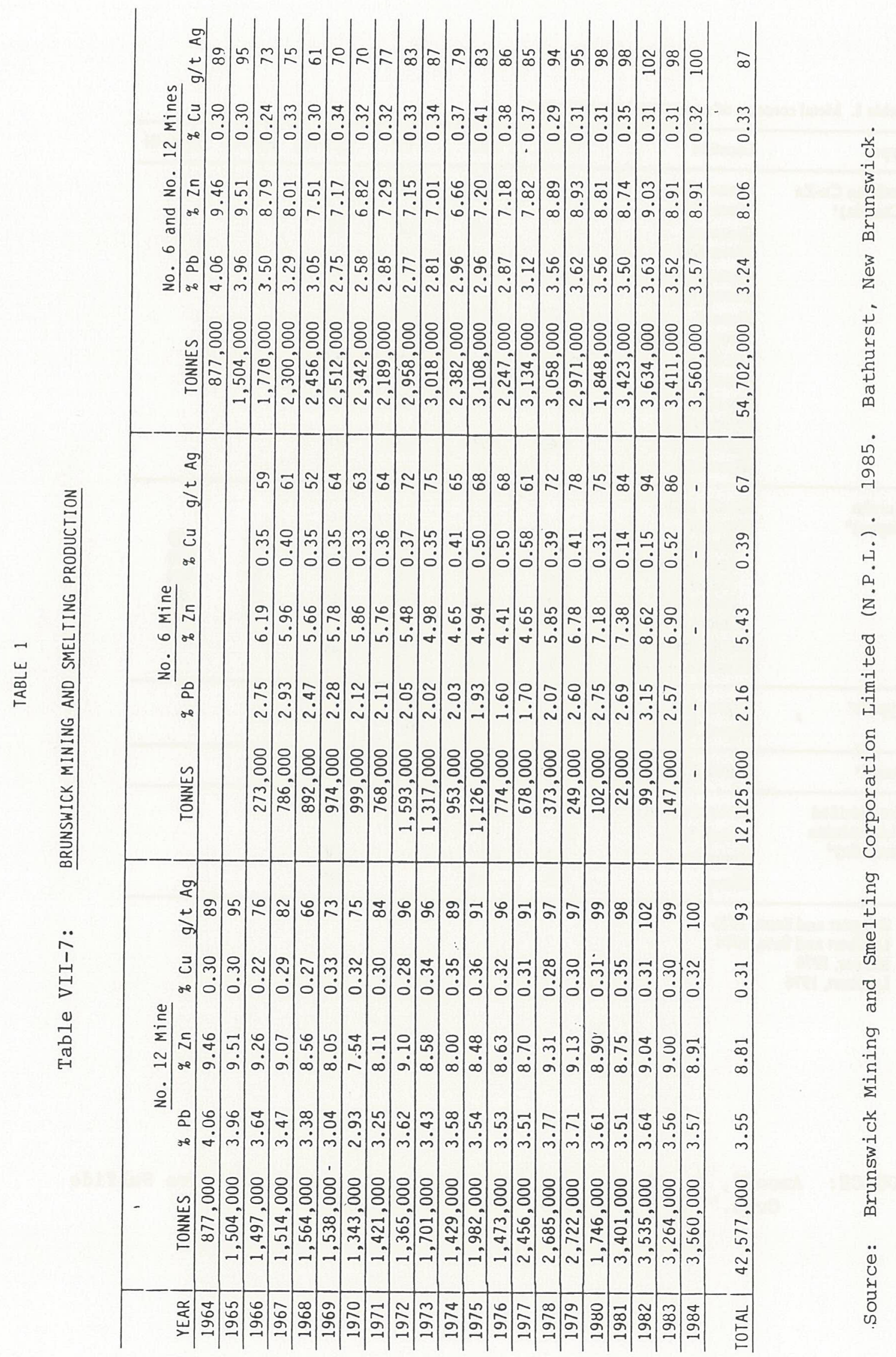




\section{Appendix VII-1: References}

Bäcker et a1. 1985. "Hydrothermal Activity and Sulfide Formation in Axial Valleys of the East Pacific Rise Crest Between $18^{\circ}$ and $22^{\circ} \mathrm{S} .^{\prime}$ Earth Planet. Sci. Lett. 72: 9-22.

Ballard, R.D. 1984a. "Systematic Variations in Volcanic, Tectonic, and Hydrothermal Processes Along Three Separate Segments of the Mid-Ocean Ridge (1 to $16 \mathrm{~cm}$ per year) based on ANGUS Surveys and Visual Observations by the Nuclear Submarine NR-1 and the French Submarine Cyana." EOS, Trans. Am. Geophys. Union 65(45): 1103.

Ballard, R.D. 1984b. "The Exploits of ALVIN and ANGUS: Exploring the East Pacific Rise." Oceanus 27: 7-14.

Ballard, R.D. et al. 1984. "Geological Setting of Hydrothermal Activity at $12^{\circ} 50^{\prime} \mathrm{N}$ on the East Pacific Rise: A Submersible Study." Earth Planet. Sci. Lett. 69: 176-186.

Ballard, R.D. et al. 1982. "The Galapagos Rift at $86^{\circ} \mathrm{W}:$ 5. Variations in Volcanism, Structure, and Hydrothermal Activity Along a $30 \mathrm{~km}$ Segment of the Rift Valley." J. Geophys. Res. 87: 1149-1161.

Ballard, R.D. et al. 1981. "Geology and High Temperature Hydrothermal Circulation of Ultra-Fast Spreading Ridge: East Pacific Rise at $20^{\circ} \mathrm{S} . "$ EOS, Trans. Am. Geophys. Union 62: 912.

Binns, R.A. et al. 1986. "Ridge Propagation into Continental Crust: The Apri1 1986 PACLARK Cruise to Western Woodlark Basin." EOS, Trans. Am. Geophys. Union 67(44): 1231 .

Both, R. et al. 1986. "Hydrothermal Chimneys and Associated Fauna in the Manus Back-Arc Basin, Papua New Guinea." EOS, Trans. Am. Geophys. Union 67(21): 489-490.

Boulegue, J. et al. 1984. "A High Temperature Hydrothermal Deposit on the East Pacific Rise Near $7^{\circ} \mathrm{N}$." Earth Planet. Sci. Lett. 70: 249-259.

Bowers, T.S. et al. 1985. "'Black Smokers' at $21^{\circ} \mathrm{N}$, EPR Revisited: 1979, 1981, 1985." EOS, Trans. Am. Geophys. Union 66(46): 921.

Canadian American Seamount Expedition (CASM). 1985. "Hydrothermal Vents on an Axis Seamount of the Juan de Fuca Ridge." Nature 313 (17 January): 212-214.

Canadian American Seamount Expedition (CASM). 1983. "Hydrothermal Vents and Sulfide Deposits, Axial Seamount, Juan de Fuca Ridge." Proc. Oceans '83: 801.

Chase, R.L. et a1. 1985. "Exploration of Southern Explorer Ridge for Hydrothermal Vent Fields." EOS, Trans. Am. Geophys. Union 66(3): 23. 
Craig, H. et al. 1987. "PAPATUA Expedition I: Hydrothermal Vent Surveys in Back-Arc Basins: the Lau, Fiji, Woodlark, and Manus Basins and Havre Trough." EOS, Trans. Am. Geophys. Union 68(7): 100.

Davis, E.E. 1986. Personal communication. Vancouver: Pacific Geoscience Center, Geological Survey of Canada. July 16.

Davis, E.E. et al. 1987. "Massive Sulfides in a Sedimented Rift Valley, Northern Juan de Fuca Ridge." Earth Planet. Sci. Lett. 82: 49-61.

Delaney, J. 1985. "Polymetallic Sulfide Research." Presentation at conference on The Exclusive Economic Zone: Exploring the New Ocean Frontier. Washington: NOAA, Department of the Interior, Smithsonian Institution, October 2.

Embley, R.W. et al. 1986. "Geologic Setting of an Extinct Hydrothermal System on the Galapagos Ridge." EOS, Trans. Am. Geophys. Union 67(44): 1185.

Francheteau, J. et al. 1979. "Massive Deep-Sea Sulphide Ore Deposits Discovered on the East Pacific Rise." Nature 277: 523-528.

Francheteau, J. and Ballard, R.D. 1983. "The East Pacific Rise Near $21^{\circ} \mathrm{N}, 13^{\circ} \mathrm{N}$, and $20^{\circ} \mathrm{S}$ : Inferences for Along-Strike Variability of Axial Processes of the Mid-Ocean Ridge." Earth Planet. Sci. Lett. 64: 93-116. $35-60$.

Halbach, P. 1984. "Deep-Sea Metallic Deposits." Ocean Management 9:

Hammond, S.R. 1986. As reported in "New Vent Field in Eastern Pacific." EOS, Trans. Am. Geophys. Union 67(36): 667.

Hammond, S.R. et a1. 1986. "Pisces Submersible Exploration of a High-Temperature Vent Field in the Caldera of Axial Volcano, Juan de Fuca Ridge." ("ASHES Expedition.") EOS, Trans. Am. Geophys. Union 67(44): 1027.

Hammond, S.R. et al. 1984. "Discovery of High-Temperature Hydrothermal Venting on the Endeavor Segment of the Juan de Fuca Ridge." EOS, Trans. Am. Geophys. Union 65(45): 1111.

Hannington, M.D. and Scott, S.D. Submitted. "Mineralogy and Geochemistry of a Silica-Sulfide-Sulfate Deposit in the Caldera of Axial Seamount, N.E. Pacific Ocean. Can. Mineralogist.

Hannington, M.D. and Scott, S.D. 1985a. "A Caldera-Hosted Silica-Sulfate-Sulfide Deposit, Axial Seamount, Central Juan de Fuca Ridge, N.E. Pacific Ocean." Geological Association of Canada/Mineralogical Association of Canada Abstracts, p. A24.

Hannington, M.D. and Scott, S.D. 1985b. "The Explorer Ridge Polymetallic Sulphide Deposits: A Major Find in Canadian Pacific Waters." Presented at Underwater Mining Institute, Halifax, N.S., October. 
Hawkins, J. 1986. "'Black Smoker' Vent Chimneys." EOS, Trans. Am. Geophys. Union 67(17): 430 .

Hekinian, R. et al. 1984. "Submersible Study of the East Pacific Rise." Nature 311: 606.

Hekinian, R. et al. 1983a. "Geology of Massive Hydrothermal Deposits from Fast Spreading Segments of the East Pacific Rise Near $12^{\circ} 50^{\prime} \mathrm{N}$ and $11^{\circ} 30^{\prime}$ N." Proc. Oceans '83: 816.

Hekinian, R. et al. 1983b. "East Pacific Rise Near $13^{\circ} \mathrm{N}$ : Geology of New Hydrothermal Fields." Science 219 (18 March): 1321-1324.

Hekinian, R. et al. 1983c. "Intense Hydrothermal Activity at the Axis of the East Pacific Rise Near $13^{\circ} \mathrm{N}$ : Submersible Witnesses the Growth of Sulfide Chimney." Mar. Geophys. Res. 6: 1-14

Hekinian, R。 et a1. 1981. "Sulfide Deposits: East Pacific Rise Near $13^{\circ} \mathrm{N} . "$ EOS, Trans. Am. Geophys. Union 62(45): 913.

Hekinian, R. et a1. 1980. "Sulfide Deposits from the East Pacific Rise Near $21^{\circ} \mathrm{N} . "$ Science 207 (28 March): 1433-1444.

Honnorez, J. et al. 1986. "Mineralogy and Geology of the Snake-Pit Hydrothermal Sulfide Deposit on the Mid-Atlantic Ridge at $23^{\circ} \mathrm{N} . "$ EOS, Trans. Am. Geophys. Union 67(44): 1214.

Horibe, Y. and H. Craig. 1987. "PAPATUA Expedition III: Hydrothermal Vents in the Marianas Trough and Kagoshima Bay (Sakurajima Volcano)." EOS, Trans. Am. Geophys. Union 68(7): 100.

Horibe, Y. et a1. 1986. "Hydrothermal Methane Plumes in the Mariana Back-Arc Spreading Centre." Nature 324: 131-133.

Hotta, H. 1987. "Deep Sea Research Around the Japanese Islands." Oceanus $30(1): 32-34$.

Humphris, S. 1986. "Ocean Drilling Program Leg 106: Bare Rock Drilling." Presentation (with P. Shaw) Dept. of Geology and Geophysics, Woods Hole Oceanog. Inst. March 4.

Karsten, J. et al. 1984. "Regional setting and local Character of a Hydrothermal Field/Sulfide Deposit on the Endeavor Segment of the Juan de Fuca Ridge." EOS, Trans. Am. Geophys. Union 65(45): 1111.

Kastens, K.A. and W.B.F. Ryan. 1986. "Structural and Volcanic Expression of a Fast Slipping Ridge-Transform-Ridge-Plate Boundary: SeaMARC I and Photographic Surveys at the Clipperton Transform Fault." Journal of Geophysical Research 91(B3): 3469-3488.

Kastner, M. 1985. "Comparisons of Hydrothermal Systems at $21^{\circ} \mathrm{N}$ East Pacific Rise and Guaymas Basin." Presentation at seminar, Department of Geology and Geophysics, Woods Hole Oceanographic Institution, August 28. 
Kingston, M.J. et a1. 1983. "Sulfide Deposits from the Juan de Fuca Ridge at $47^{\circ} 57^{\prime} \mathrm{N}, 129^{\circ} 06^{\prime} \mathrm{W} . "$ Proc. Oceans '83: 811-815.

Koski, R.A. and K.A. Kvenvolden. 1986. "Polymetallic Sulfide Associated with Asphaltic Petroleum at the Gorda Ridge Spreading Center, Offshore Northern California." EOS, Trans. Am. Geophys. Union 67(44): 1282-83.

Koski, R.A. et a1. 1985. "Mineralogy and Geochemistry of a Sediment-Hosted Hydrothermal Sulfide Deposit From the Southern Trough of Guaymas Basin, Gulf of California." Journal of Geophysical Research 90(B8): 6695-6707.

Koski, R.A. et al. 1982. "Metal Sulfide Deposits on the Juan de Fuca Ridge." Oceanus 25 (Fall): 42-48.

Law, S. et a1. 1981. "Massive Polymetallic Sulfides of the Galapagos Rift." EOS, Trans. Am. Geophys. Union 62: 1027.

Lonsdale, P.F. 1980. "Hydrothermal Plumes and Baritic Sulfide Mounds at a Gulf of California Spreading Center." EOS, Trans. Am. Geophys. Union 61: 995.

Lonsdale, P.F. et a1. 1980. "A High Temperature Hydrothermal Deposit on the Seabed at a Gulf of California Spreading Center." Earth Planet. Sci. lett. 49: 8-20.

Lonsdale, P.F. et a1. 1982a. "Submersible Study of Active Hydrothermal Vents and Massive Sulfide Deposits on Young Off-Ridge Volcanoes Near the East Pacific Rise at $20^{\circ} 48^{\prime} \mathrm{N}$." EOS, Trans. Am. Geophys. Union, 63(18): 472.

Lonsdale,"P.F. et al. 1982b. "Metallogenesis at Seamounts on the East Pacific Rise. Mar. Tech. Soc. J. 16(3): 54-61.

MacDonald, K.C. et al: 1986. "13 New Hydrothermal Vent Sites Found on the East Pacific Rise, $20^{\circ}-21^{\circ} \mathrm{S}$." EOS, Trans. Am. Geophys. Union, 67(44): 1232.

Malahoff, A. 1985. "Hydrothermal Vents and Polymetallic Sulfides of the Galapagos/Juan de Fuca Ridge Systems and of Submarine Volcanoes." Biol. Soc. Wash. Bul1. 6: 19-41.

Malahoff, A. 1982a. "Massive Enriched Polymetallic Sulfides of the Ocean Floor--A New Commercial Source for Strategic Minerals." Proc. 14th Offshore Tech. Conf. OTC 4293: 725-728.

Malahoff, A. 1982b. "Polymetallic Sulfides from the Oceans to the Continents." Sea Technology 23: 51-56.

Malahoff, A. 1982c. "A Comparison of the Massive Submarine Polymetallic Sulfides of the Galápagos Rift with Some Continental Deposits." Mar. Tech. Soc. J. 16: 39-45.

Malahoff, A. 1981. "Comparison Between Galápagos and Gorda Spreading Centers." Proc. 13th Offshore Tech. Conf. OTC 4129: 115-117. 
Malahoff, A. et al. 1987. "Fault-Controlled Massive Polymetallic Sulfide Deposits, Galapagos Ridge." EOS, Trans. Am. Geophys. Union, 68(7): 101.

Malahoff, A. et al. 1983. "The Geological Setting and Chemistry of Hydrothermal Sulfides and Associated Deposits from the Galapagos Rift at $86^{\circ} \mathrm{W} . "$ Marine Mining 4: 123-137.

McConachy, T. 1987. Personal communication. Toronto: Department of Geology, University of Toronto, February 15.

McConachy, T. et al. 1986a. "Particulate Matter Concentration in Western Woodlark Basin: Evidence for Hydrothermal Activity." EOS, Trans. Am. Geophys. Union 67(44): 1028.

McConachy, T. et a1. 1986b. "Geological Form and Setting of a Hydrothermal Vent Field at Iat $10^{\circ} 56^{\prime} \mathrm{N}$, East Pacific Rise: A Detailed Study Using Angus and Alvin." Geology 14: 295-298.

McConachy, T. et al. 1984. "Geological Form and Setting of a Recently Discovered Hydrothermal Ventfield at $10^{\circ} 56^{\prime} \mathrm{N}, 103^{\circ} 41^{\prime} \mathrm{W}$ East Pacific Rise." EOS, Trans. Am. Geophys. Union 65(45): 1124.

Morton, J.L. et al. 1986. "Sedimentary Setting of Massive Sulfide Deposits, Escanaba Trough, Offshore Northern California." EOS, Trans. Am. Geophys. Union 67(44): 1282-83.

Normark, W.R. et al. 1986. "Active Hydrothermal Vents and Sulfide Deposits on the Southern Juan de Fuca Ridge." Geology 11: 158-163.

Normark, W.R. et al. 1985. "Submarine Fissure Eruption and Associated Hydrothermal Vents Along the Southern Juan de Fuca Ridge." EOS, Trans. Am. Geophys. Union 66(10): 116.

Normark, W.R. et al. 1982. "Polymetallic Sulfide Deposits and Water Column Tracers of Active Hydrothermal Vents on the Southern Juan de Fuca Ridge." Mar. Tech. Soc. J. 16: 46-53.

Ocean Science News. 1986. "The Soviet News Agency TASS said Russian Scientists Observed Hot-Water Springs on the Floor of the Sea of Okhotsk Near Paramushir, One of the Northern Islands of the Kurile Chain." Washington: Nautilus Press, Inc. (February 3), p. 3.

Peter, J.M. and Scott, S.D. 1985. "Mineralogy and Geochemistry of Hydrothermal Vent Deposits, Guaymas Basin, Gulf of California." In Geological Association of Canada and Mineralogical Association of Canada, Abstracts, p. A48.

Philpotts, J. et a1. 1985. "Chemical Composition of Massive Sulfides and Hydrothermal Fluids from the Southern Juan de Fuca Ridge." EOS, Trans. Am. Geophys. Union 66(46): 926.

Renard, V. et a1. 1985. "Submersible Observations at the Axis of the Ultra-fast-spreading East Pacific Rise ( $17^{\circ} 30^{\prime}$ to $\left.21^{\circ} 30^{\prime} \mathrm{S}\right)$. $^{\text {Earth Planet. }}$ Sci. Lett. 75: 339-353. 
Rona, P.A. et al. 1986a. "Geologic Setting and Heat Transfer of Black Smokers at TAG Hydrothermal Field, Mid Atlantic Ridge $26^{\circ} \mathrm{N} . "$ EOS, Trans. Am. Geophys. Union 67(44): 1021.

Rona, P.A. et a1. 1986b. "Black Smokers, Massive Sulfides and Vent Biota at the Mid-Atlantic Ridge." Nature 321: 33-37.

Rona, P.A. 1985. "Black Smokers and Massive Sulfides at the TAG Hydrothermal Field, Mid Atlantic Ridge $26^{\circ} \mathrm{N} . "$ EOS, Trans. Am. Geophys. Union $66(46): 936$.

Schroeder, B. et al. 1986. "Hydrothermal Mineralization, TAG Area, Mid-Atlantic Ridge $26^{\circ} \mathrm{N} . "$ EOS, Trans. Am. Geophys. Union 67(44): 1022.

Scott, S.D. et al. 1985. "Explorer Ridge and Tuzo Wilson Seamounts: Update." EOS, Trans. Am. Geophys. Union 66(46): 925.

Scott, S.D. et al. 1984. "Tectonic Framework and Sulfide Deposits of Southern Explorer Ridge, Northeastern Pacific Ocean." EOS, Trans. Am. Geophys. Union 65(45): 1111 .

Skirrow, R. and Coleman, M.L. 1982. "Origin of Sulphur and Geothermometry of Hydrothermal Sulphides from the Galapagos Rift, $86^{\circ} \mathrm{W} . "$ Nature 299 ( 9 September): 142-144.

Speiss, F.N. et a1. 1980. "East Pacific Rise: Hot Springs and Geophysical Experiments." Science 207(4438): 1421-1433.

Sul.anowska, M. et a1. 1986. "Hydrothermal Mineralization in the MARK Area, Mid-Atlantic Ridge $23^{\circ} \mathrm{N} . "$ EOS, Trans. Am. Geophys. Union 67(44): 1214.

Tarasov, V.G. et al. 1986. "Shallow Hydrothermal Vents and a Unique Ecosystem of Kraternaya Caldera, Kuril Islands." Mar. Biol. Vladivostok 2: 774.

Taylor, B. et a1. 1986. "Extensional Transform Zone, Sulphide Chimneys and Gastropod Vent Fauna in the Manus Back-Arc Basin." EOS, Trans. Am. Geophys. Union 67(16): 377.

Tivey, M.K. and Delaney, J.R. 1985. "Controls on the Distribution and Size of Hydrothermal Vent Structures on the Endeavor Segment, Juan de Fuca Ridge." EOS, Trans. Am. Geophys. Union 66(46): 926.

Tunnicliffe, V. et a1. 1986. "Hydrothermal Vents of Explorer Ridge, Northeast Pacific." Deep-Sea Research 33(3): 401-412.

Tunnicliffe, V. et al. 1985. "Along Strike Variation in Hydrothermal Activity on Explorer Ridge, N.E. Pacific." EOS, Trans. Am. Geophys. Union 66(10): 116. Also found at: EOS, Trans. Am. Geophys. Union 65(45): 1124 (1984). 
U.S. Geological Survey (USGS). 1985. "Sulfide Deposits on Gorda Ridge." EOS, Trans. Am. Geophys. Union 66(51): 1233.

Uyeda, S. 1987. "Active Hydrothermal Mounds in the Okinawa Back-Arc Trough." EOS, Trans. Am. Geophys. Union 68(36): 737.

Van Dover, C.L. et al. In press. "Prediction of Hydrothermal Vent Local:ions from Brachyuran Crab Distributions." Limnology and Oceanography.

Zierenberg, R.A. et a1. 1986. "Form and Composition of Sediment-Hosted Sulfide-Sulfate Deposits, Escanaba Trough, Southern Gorda Rille $e^{\circ}$ EOS, Trans. Am. Geophys. Union 67(44): 1282 . 
Section VIII: World Consumption, Production, and Trade in Zinc and Copper

This section summarizes world consumption, production, and trade for two metal commodities, zinc and copper, over the 75 year period from 1908 through 1983. Both commodities are traded in world markets. We identify zinc and copper as the two commodities most likely to be examined first for future production from marine polymetallic sulfide (MPS) deposits. Copper might also be produced from manganese nodule deposits. In any consideration of potential production from offshore sources, it is important to understand patterns in and national shares of world consumption, production, and trade of metal commodities, like zinc and copper. In general, to the extent that one or more nations might exert market control over trade in metal commodities, resulting price effects or heightened national concerns about sources of supply for defense needs might call offshore sources of minerals into production. Furthermore, an analysis of this sort is a first step at identifying the "winners" and "losers" or the relative position of nations in the world trade of meta1 commodities.

It would be useful to compile this information for all of the prospective marine mineral resources. Some marine minerals, like sand and gravel, shell, and, in some cases, phosphorites, are traded in local markets and so a worldwide analysis would be inappropriate. Others like hydrocarbons, sulfur, and tin, have experienced periods during which market control was exercised by producers or by combinations of producers and consumers. It is interesting to note that in these latter cases, offshore production already has occurred. Still others, like cobalt, platinum, manganese, and chromite, have attracted considerable interest as "strategic" minerals (OTA, 1985). In the United States, the Department of the Interior's Office of Strategic and International Minerals has spent several million dollars to draft an environmental impact statement on the potential lease sale of OCS lands off the coast of Hawaii containing cobalt-rich ferromanganese crusts (MMS, 1987). We restrict ourselves to an examination of zinc and copper, as potential MPS commodities, and present this as an example for the analysis of other minerals, should the interest arise.

The data were compiled for the 25 and 50 year intervals: 1908, 1933 and 
1983. The world's leading consumer countries, producer countries, and trading countries are listed in order of amounts consumed or produced in 1983. The tables describing the zinc market are presented first in Figures VIII- 1 to VIII-8, with the copper tables following in Figures VIII-9 to VIII-12. Copper production involves three phases during which statistics are available: minehead, smelting, and refining. Zinc production involves only the two phases of mining and smelting.

Next, in Figures VIII-4 to VIII-7 (zinc) and Figures VIII-13 to VIII-16 (copper), the leading exporters and importers are ranked in terms of zinc or copper exports or imports as a percentage of, respectively, total country exports or imports and as a percentage of gross national product (GNP). Only 1981 was examined, using recent data from the World Bank, the U.N. Conference on Trade and Development, and the U.S. Census Bureau. Finally, in Figure VIII-8 (zinc) and Figure VIII-17 (copper), a net value trade or difference between the value of exports and imports in 1981 was computed. Those nations with the highest trade surpluses or the lowest trade deficits are ranked.

Perhaps the most striking aspect of the production data is the decreasing international concentration in both zinc and copper production from 1908 and 1933 through 1983. In 1933, the United States held the largest share of copper production in the mine $(16 \%)$, smelter $(22 \%)$, and refined $(32 \%)$ phases. By 1983 , those shares had decreased to $13 \%, 12 \%$, and $16 \%$ respectively. In zinc production, the leading shares held by the United States of $30 \%$ in the mine phase and $28 \%$ in the smelter phase decreased to $5 \%$ each by 1983 . A similar phenomenon occurred in zinc and copper consumption where the United States as the leading consumer in 1933 of zinc (29\%) and copper (28\%) consumed a smaller share of the total market in 1983 of zinc $(15 \%)$ and copper (19\%). It is interesting that, over the 75 year period, the volume of zinc and copper in world trade increased substantially ( 9 times for zinc and 13 times for copper); market concentration in zinc and copper decreased, with a substantial increase in the number of producer countries; and the real prices of $z$ inc and copper (see section II) fell during this period.

In Figure VIII-18, constructed for copper only, net trade flows where placed into a matrix that displays net trade volume for the years 1973, 1978, and 1983. The matrix identifies the net flow of copper from exporting nations to importing nations. The data were compiled from Metallgesellschaft, 1984. It also identifies the gross flow of copper from net exporters to gross 
importers (nonproducers) and gross flow from gross exporters (nonconsumers) to net importers. In 1983, the United States, as a net importer of copper, received most of its imports from Chile, Canada, Zambia, and Peru, although it received copper from several other countries as we1l. The United States did export copper, as shown in Figure VIII-17, valued in 1981 at about a third of its imports. Copper exports from net importers and imports from net exporters are not shown in Figure VIII-18. China has recently become a large consumer of Canadian copper, second only to the United States and may become a larger factor in the copper market.

Zinc exports, in most cases, represent a small share of the leading export nations' total exports and GNP (Figures VIII-4 and VIII-5). Only in the case of Peru do zinc exports exceed one percent of GNP. Conversely, for several countries including Zambia, Zaire, Papua New Guinea, Chile, and Peru, copper exports, shown in Figures VIII-13 and VIII-14, represent a substantial portion of total exports and GNP. Belgium still remains a large export market for Zaire (formerly the Belgian Congo); Belgium imports more than half of Zairean copper ore. Copper exports are almost one-third the size of Zambia's GNP. The United States is the largest export market for Chilean and Peruvian refined copper.

Imports of copper or zinc do not represent very large proportions of total imports or GNP of any country, as seen from Figures VIII-6, VIII-7, VIII-15, VIII-16. Belgium and Luxembourg, counted together as important metal commodity entrepots, have the highest proportion of copper and zinc imports as a percent of GNP, with $0.38 \%$ for zinc and $2.00 \%$ for copper. Copper exports are more than one percent of GNP for these two countries as well (Figure VIII-14). Belgium and Luxembourg trade copper with more countries than any other, with the possible exception of West Germany.

Examination of the balance of value trade in zinc and copper (Figures VIII-8 and VIII-17) shows that Canada, Australia, and Peru benefit greatly from export trade in zinc while Chile, Zambia, Canada, Zaire, and Peru hold the highest trade surpluses in copper. The United States has the leading trade deficit in zinc at more than $\$ 600$ million, with a comparable trade deficit in copper of $\$ 584$ million. Japan has the largest trade deficit in copper by far with more than $\$ 2.2$ billion. Japan is followed by several European countries and the United States. The trade balance data demonstrate the general dependence of the developed European countries and the United 
States upon developing countries and Canada and Australia for zinc and copper. The extent to which the general balance of trade, and the country rankings, will remain stable over time is uncertain. However, new sources of high-grade zinc and copper deposits, such as MPS, have the potential in the distant future of rearranging national trade balances in these markets.

\section{Sources}

Census Bureau. 1983. Statistical Abstract of the United States. Washington: U.S. Department of Commerce.

Metallgesellschaft. 1984. Metallstatistik. Frankfurt am Main: Metallgesellschaft Aktiengesellschaft.

Metallgesellschaft. 1936. Metallstatistik. Frankfurt am Main: Metallgesellschaft Aktiengesellschaft.

Metallgesellschaft. 1910. Metallstatistik. Frankfurt am Main: Metallgesellschaft Aktiengesellschaft.

Minerals Management Service (MMS). 1987. Draft Environmental Impact Statement: Proposed Marine Mineral Lease Sale in the Hawaiian Archipelago and Johnston Island Exclusive Economic Zones. Reston, Va.: U.S. Department of the Interior.

Office of Technology Assessment (OTA). 1985. Strategic Materials: Technologies to Reduce U.S. Import Vulnerability. Washington: U.S. Congress.

United Nations. 1982. Yearkook of International Trade Statistics. Vo1. 2. New York.

United Nations Conference on Trade and Development (UNCTAD). 1984. Yearbook of International Commodity Statistics. New York.

World Bank. 1983. World Tables. 3rd Edit. Baltimore: Johns Hopkins University Press. 
Figure VIII-1: REFINED ZINC CONSUMPTION

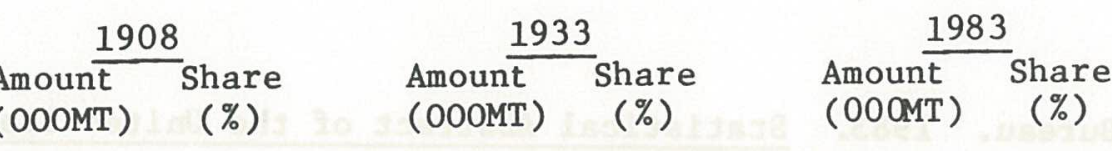

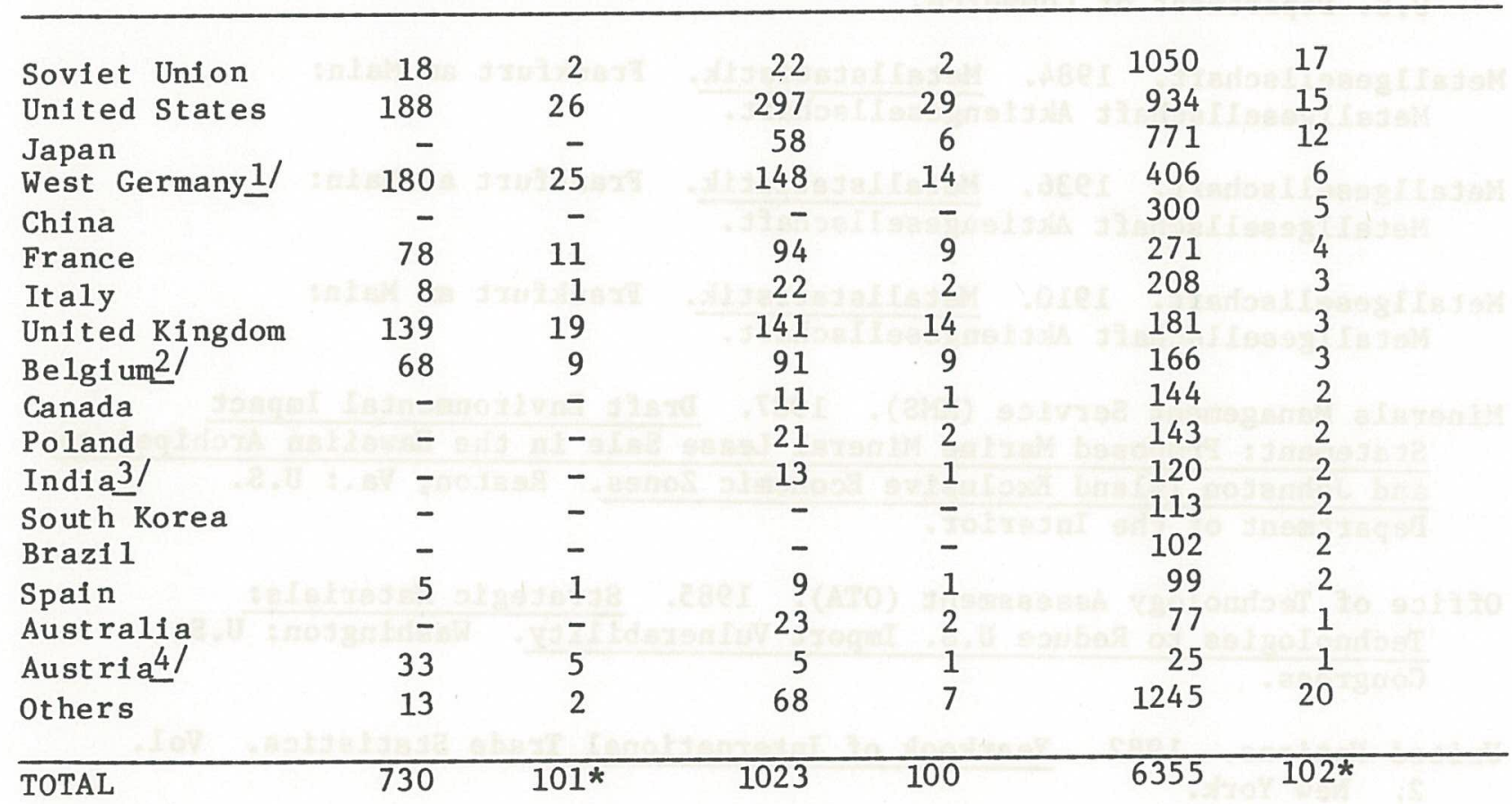

Notes:

1/West Germany and East Germany are combined in 1933 data.

$\overline{2} /$ Includes Luxembourg.

$\overline{3} /$ "British India" in 1933.

$\underline{4}$ /Austria and Hungary combined in 1908.

Source: Metallgese11schaft, 1910, 1936, 1984.

*Columns may not total 100 due to rounding error. 
Figure VIII-2: ZINC MINE PRODUCTION

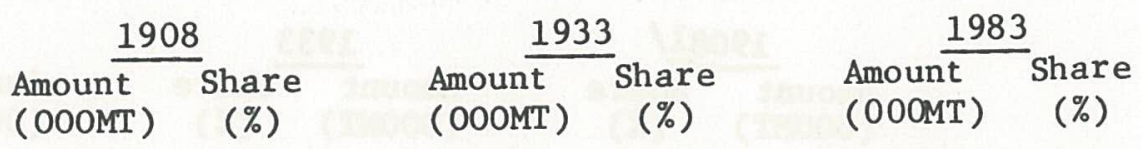

\begin{tabular}{|c|c|c|c|c|c|}
\hline CanadaI/ & & 159 & 14 & 1070 & 16 \\
\hline Soviet Union2/ & & 22 & 2 & 1025 & 16 \\
\hline Australia & & 126 & 11 & 695 & 11 \\
\hline Peru & & - & - & 553 & 9 \\
\hline United States & & 349 & 30 & 293 & 5 \\
\hline Mexico & & 89 & 8 & 275 & 4 \\
\hline Japan & & 15 & 1 & 256 & 4 \\
\hline Sweden & No data & 25 & 2 & 203 & 3 \\
\hline Poland & available & 42 & 4 & 189 & 3 \\
\hline $\begin{array}{l}\text { Ireland } \\
\text { Spain }\end{array}$ & & - & - & 186 & 3 \\
\hline $\begin{array}{l}\text { Spain } \\
\text { China }\end{array}$ & & 35 & 3 & 169 & 3 \\
\hline $\begin{array}{l}\text { China } \\
\text { North Korea }\end{array}$ & & 2 & 1 & 160 & 2 \\
\hline $\begin{array}{l}\text { North Korea } \\
\text { West Germany } 3 \text { / }\end{array}$ & & - & - & 120 & 2 \\
\hline $\begin{array}{l}\text { West Germany } 3 / \\
\text { Sout h Africa }\end{array}$ & & 107 & 9 & 114 & 2 \\
\hline & & $\overline{-}$ & $\overline{-}$ & 108 & 2 \\
\hline $\begin{array}{l}\text { Yugoslavia } \\
\text { Italy }\end{array}$ & & 44 & 4 & 87 & 1 \\
\hline & & 29 & 3 & 43 & 1 \\
\hline $\begin{array}{l}\text { Zambia4/ } \\
\text { India } 57\end{array}$ & & 19 & 2 & 42 & 1 \\
\hline $\begin{array}{l}\text { India } 57 \\
\text { Others }\end{array}$ & & 33 & 3 & 37 & 1 \\
\hline & & 54 & 5 & 873 & 13 \\
\hline
\end{tabular}

$1 / 1933$ data includes Newfoundland.

$\overline{2} / 1933$ data includes Russia in Europe and Russia in Asia.

$\overline{3} / 1933$ data includes West Germany and East Germany.

4/1933 data is for "Rhodesia".

5/ 1933 data is for "British India".

Source: Metallgesellschaft, 1936, 1984.

*Columns may not total 100 due to rounding error. 
Figure VIII-3: ZINC SMELTER PRODUCTION
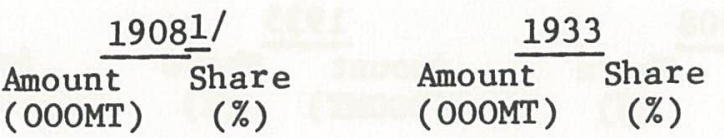

$\underset{(000 \mathrm{MT})}{\frac{1983}{\mathrm{Amoun}}} \underset{(\%)}{\text { Share }}$

\begin{tabular}{|c|c|c|c|c|c|c|}
\hline Soviet Union2/ & 9 & 1 & 17 & 2 & 1060 & 17 \\
\hline Japan & - & - & 31 & 3 & 701 & 11 \\
\hline Canada & - & - & 83 & 8 & 617 & 10 \\
\hline West Germanyㅡ/ & 217 & 30 & 51 & 5 & 356 & 6 \\
\hline United States & 190 & 26 & 279 & 28 & 305 & 5 \\
\hline Australia & 1 & - & 55 & 6 & 299 & 5 \\
\hline Belgi um4/ & 165 & 23 & 137 & 14 & 263 & 4 \\
\hline France 57 & 56 & 8 & 56 & 6 & 250 & 4 \\
\hline Spain & - & - & 9 & 1 & 190 & 3 \\
\hline Netherlands & 17 & 2 & 19 & 2 & 188 & 3 \\
\hline China & - & - & - & - & 185 & 3 \\
\hline Mexico & - & - & 27 & 3 & 180 & 3 \\
\hline Poland & - & - & 83 & 8 & 170 & 3 \\
\hline Finland & - & - & - & - & 155 & 2 \\
\hline Peru & - & - & - & - & 154 & 2 \\
\hline South Korea & - & - & - & - & 108 & 2 \\
\hline Brazil & - & - & - & - & 100 & 2 \\
\hline North Korea & - & - & - & - & 95 & 2 \\
\hline Norway & - & - & 45 & 5 & 91 & 1 \\
\hline United Kingdom & 54 & 7 & 42 & 4 & 88 & 1 \\
\hline Others & 13 & 2 & 52 & 5 & 744 & 12 \\
\hline TOTAL & 722 & $99 *$ & 986 & 100 & 6299 & $101 \%$ \\
\hline
\end{tabular}

Notes:

1/"Spelter" production.

$\overline{2} / 1933$ data $=$ Russia in Europe \& Asia

$\overline{3} / 1933$ data $=$ West Germany \& East Germany or 01d Germany.

4/Includes Luxembourg.

$\underline{\overline{5}} /$ Includes Spain (1908).

Source: Metallgesellschaft, 1910, 1936, 1984.

*Columns may not total 100 due to rounding error. 
Figure VIII-4: ZINC EXPORTS AS A PERCENT OF TOTAL EXPORTS: 1981

\section{Value of Total Zinc}

Export Trade

Current \$US $\times 106$
Value of

233.74

38.27

12.25

281.58

12.95

626.55

2.71

45.08

102.86

84.71
Total Exports

Current

\$US $\times 10^{9}$
3.94

1.02

0.87

26.35

1.22

79.55

0.46

10.49

17.01

28.60
Zinc Export

Values as a

Percent of

Country's Total

Exports

(\%)

Canada

Burma

Ireland

Finland

Mexico

5.94

3.76

1.41

1.07

1.06

0.79

0.59

0.43

0.60

0.30

Source: United Nations, 1982; World Bank, 1983. 
Figure VIII-5: ZINC EXPORTS AS A PERCENT OF GNP: 1981

Total Zinc
Export
Trade Values
Current
\$US x 106

\section{Country}

Peru

Bolivia

Honduras

Zambia

Belgium

Ireland

Canada

Finland

Australia

Sweden

\author{
Share of World \\ Total Zinc \\ Export Trade \\ Values
}

$(\%)$
Gross Nationa1
Product

Current

\$US $\times 10^{9}$
Zinc Export Trade Values as a \% of GNP

(\%)

Source: World Bank, 1983; United Nations, 1982; Census Bureau, 1983. 
Figure VIII-6: ZINC IMPORTS AS A PERCENT OF TOTAL IMPORTS: 1981

Value of
Total Zinc
Import Trade

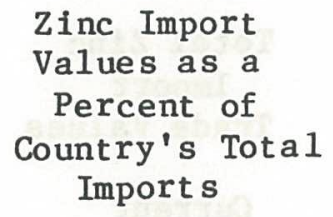

Current

\$US $\times 10^{9}$

$\begin{array}{lll}\text { Current } & \text { \$US } \times 10^{9}\end{array}$

India
Thailand
Finland
Belgium1/
United States
Tanzania
Philippines
France
Greece
West Germany

63.55
37.08
41.71
176.82
647.44
2.20
18.17
232.05
16.15
292.92

16.82

10.71

16.23

69.98

306.20

1.12

9.35

143.16

10.11

197.17
0.38
0.35
0.26
0.25
0.21
0.20
0.19
0.16
0.16
0.15

Notes:

1/Includes Luxembourg.

Source: United Nations, 1982; World Bank, 1983. 
Figure VIII-7: ZINC IMPORTS AS A PERCENT OF GNP: 1981

Total Zinc
Import
Trade Values
Current
\$US $\times 106$

\section{Belgium1/}

Singapore

Hong Kong

Thailand

Finland

Netherlands

New Zealand

Malaysia

Kenya

Portuga 1

176.82
19.08
36.02
37.08
41.71
106.49
16.61
17.24
4.65
13.01

\begin{abstract}
Share of World
Total Zinc

Import Trade

Values
\end{abstract}

(\%)
Gross National
Product

Current

\$US $\times 10^{9}$
Zinc Import

Trade Values

as a \% of GNP

(\%)

\section{Notes:}

1/Includes Luxembourg.

6.51

0.70

1.33

1.37

1.54

3.92

0.61

0.63

0.17

0.48
46.93

12.95

25.05

35.76

48.09

140.11

24.48

24.07

6.48

22.76
0.38

0.15

0.14

0.10

0.09

0.08

0.07

0.07

0.07

0.06

Source: World Bank, 1983; United Nations, 1982; Census Bureau, 1983. 
Figure VIII-8: BALANCE OF VALUE TRADE IN ZINC: 1981

Value of
Total Zinc
Export Trade
Current
\$US $\times 106$

Surplus

Canada

Australia

Peru

Mexico

Spain

Finland

Sweden

Netherlands

Norway

Bolivia

Deficit

Hong Kong

Brazi 1

Thailand

Indi a

It aly

United Kingdom

France

West Germany

Japan

United States
626.55

281.58

233.74

84.71

80.15

102.86

80.25

152.48

69.09

38.27

2.83

2.53

0.31

0.07

22.28

40.80

110.40

151.59

48.27

37.55
Value of

Total Zinc

Import Trade

Current

\$US $\times 10^{9}$
Net Value Trade

$\overline{B a l a n c e}$ in $\mathrm{Zinc}$

Current

\$US $\times 10^{6}$
33.07

0.01

0.00

0.05

14.26

41.71

28.24

106.49

29.62

0.00

36.02

39.20

37.08

63.55

128.65

152.77

232.05

292.92

249.91

647.44
593.48

281.57

233.74

84.66

65.90

61.15

52.01

46.00

39.46

38.27

$-33.19$

$-36.67$

$-36.77$

$-63.49$

$-106.37$

$-111.96$

$-121.65$

$-141.33$

$-201.64$

$-609.89$

Source: United Nations, 1982; World Bank, 1983. 
Figure VIII-9: REFINED COPPER CONSUMPTION

$\underset{\text { Amount }}{\frac{1908}{(\text { OOOMT })}}$ Share

$\underset{\text { Amount }}{\frac{1933}{\text { (OOOMT) }}}$ Share

$\underset{\text { (000MT) }}{\frac{1983}{(\%)}}$ Share

\begin{tabular}{lrrrrrr}
\hline United States & 209 & 30 & 346 & 28 & 1775 & 19 \\
Soviet Union & 21 & 3 & 53 & 4 & 1360 & 15 \\
JapanI/ & 9 & 1 & 83 & 7 & 1216 & 13 \\
West Germany2/ & 181 & 26 & 238 & 19 & 737 & 8 \\
China & - & - & - & - & 410 & 4 \\
France & 74 & 11 & 110 & 9 & 390 & 4 \\
United Kingdom & 128 & 18 & 155 & 13 & 358 & 4 \\
Italy & 22 & 3 & 60 & 5 & 325 & 4 \\
Belgium3/ & 11 & 2 & 28 & 2 & 258 & 3 \\
Canada & - & - & 30 & 2 & 195 & 2 \\
Poland & - & - & 7 & 1 & 177 & 2 \\
South Korea & - & - & - & - & 152 & 2 \\
Brazi1 & - & - & - & - & 148 & 2 \\
Sweden & - & - & 30 & 2 & 113 & 1 \\
Austria4/ & 34 & 5 & 7 & 1 & 22 & 1 \\
Others & 9 & 1 & 91 & 7 & 1480 & 16 \\
& & & & & & \\
T0TAL & 698 & 100 & 1238 & 100 & 9116 & 100
\end{tabular}

Notes:

$1 /$ Includes Australia in 1908.

$\overline{2} /$ Includes East Germany in 1908, 1933.

$\overline{3} /$ Includes Luxembourg.

$\underline{4} /$ Includes Hungary in 1908.

Source: Metallgesellschaft, 1910; 1936; 1984. 
Figure VIII-10: COPPER MINE PRODUCTION
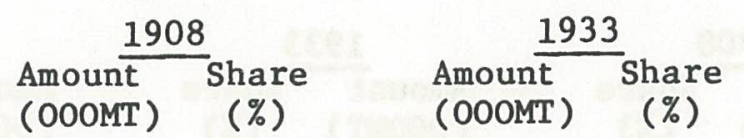

$$
\underset{(000 \mathrm{MT})}{\frac{1983}{\text { Amount }}} \underset{(\%)}{\text { Share }}
$$

\begin{tabular}{|c|c|c|c|c|c|c|}
\hline Chile & 39 & 5 & 163 & 16 & 1257 & 15 \\
\hline Soviet Unionl/ & 20 & 3 & 33 & 3 & 1180 & 14 \\
\hline United States & 430 & 55 & 173 & 16 & 1038 & 13 \\
\hline Canada & 29 & 4 & 136 & 13 & 625 & 8 \\
\hline Zambia2/ & - & - & 106 & 10 & 543 & 7 \\
\hline Zaire $3 T$ & - & - & 91 & 9 & 502 & 6 \\
\hline Poland & - & - & - & - & 402 & 5 \\
\hline Peru & 15 & 2 & 25 & 2 & 322 & 4 \\
\hline Philippines & - & - & - & - & 271 & 3 \\
\hline Australia & 40 & 5 & 15 & 1 & 264 & 3 \\
\hline South Africa4/ & 7 & 1 & - & - & 212 & 3 \\
\hline Mexico & 41 & 5 & 40 & 4 & 206 & 2 \\
\hline Papua New Guinea & - & - & - & - & 183 & 2 \\
\hline China & - & - & - & - & 175 & 2 \\
\hline Yugoslavia & - & - & 40 & 4 & 130 & 2 \\
\hline spain $5 /$ & 53 & 7 & 35 & 3 & 64 & 1 \\
\hline Japan & 44 & 6 & 69 & 7 & 46 & 1 \\
\hline Norway & 9 & 1 & 19 & 2 & 26 & 1 \\
\hline West Germany6/ & 21 & 3 & 32 & 3 & 1 & 1 \\
\hline Other & 32 & 4 & 74 & 7 & 838 & 10 \\
\hline$\overline{\text { TOTAL }}$ & 780 & $101 *$ & 1051 & 100 & 8285 & $101 \%$ \\
\hline
\end{tabular}

Notes:

$1 /$ Russia before 1983.

2/Zambia

$\overline{3} /$ Zaire

$\overline{4} /$ Cape Colony in 1908.

5/Includes Portugal in 1908.

6/Includes East Germany in 1908, 1933.

Source: Metallgesellschaft, 1910, 1936, 1984.

*Columns may not total 100 due to rounding error. 
Figure VIII-11: COPPER SMELTER PRODUCTION

\begin{tabular}{|c|c|c|c|c|}
\hline 19 & & 193 & & 83 \\
\hline $\begin{array}{l}\text { Amount } \\
\text { (OOOMT) }\end{array}$ & $\begin{array}{c}\text { Share } \\
(\%)\end{array}$ & $\begin{array}{l}\text { Amount } \\
\text { (OOOMT) }\end{array}$ & $\begin{array}{c}\text { Share } \\
(\%)\end{array}$ & $\begin{array}{l}\text { Amount } \\
\text { (000MT) }\end{array}$ \\
\hline
\end{tabular}

\begin{tabular}{lrrrrrr}
\hline Soviet UnionI/ & 17 & 2 & 33 & 3 & 1280 & 16 \\
Chile2/ & 64 & 9 & 158 & 15 & 1058 & 13 \\
Japan & 41 & 6 & 69 & 7 & 945 & 12 \\
United States & 448 & 60 & 227 & 22 & 928 & 12 \\
Zambia3/ & - & - & 106 & 10 & 563 & 7 \\
Zaire & - & - & 67 & 6 & 466 & 6 \\
Canada4/ & 14 & 2 & 118 & 11 & 337 & 4 \\
Poland & - & - & - & - & 320 & 4 \\
Peru & - & - & - & - & 296 & 4 \\
China & - & - & - & - & 195 & 2 \\
South Africa & - & - & - & - & 192 & 2 \\
Australia & 35 & 5 & 14 & 1 & 174 & 2 \\
West Germany5/ & 30 & 4 & 50 & 5 & 159 & 2 \\
Yugoslavia & - & - & 40 & 4 & 87 & 1 \\
Mexico & - & - & 40 & 4 & 67 & 1 \\
Belgium6/ & - & - & 35 & 3 & - & 1 \\
United Kingdom & 71 & 10 & 12 & 1 & 970 & 12 \\
Other & 25 & 3 & 98 & 9 & 8040 & 100 \\
& & & $101 *$ & 1040 & $101 *$ &
\end{tabular}

Notes:

$1 /$ Russia before 1983.

$\overline{2} /$ Includes South America/Central America in 1908.

3/Zambia

4/British North America in 1908.

$\overline{5} /$ Includes East Germany in 1908, 1933.

$\underline{6} /$ Includes Luxembourg.

Source: Metallgese1lschaft, 1910, 1936, 1984.

*Columns may not tota 1100 due to rounding error. 
Figure VIII-12: REFINED COPPER PRODUCTION

\begin{tabular}{|c|c|c|c|c|c|}
\hline \multicolumn{2}{|c|}{1908} & \multicolumn{2}{|c|}{1933} & \multicolumn{2}{|c|}{1983} \\
\hline $\begin{array}{l}\text { mount } \\
\text { OOOMT) }\end{array}$ & $\begin{array}{c}\text { Share } \\
(\%)\end{array}$ & $\begin{array}{l}\text { Amount } \\
\text { (OOOMT) }\end{array}$ & $\begin{array}{c}\text { Share } \\
(\%)\end{array}$ & $\begin{array}{l}\text { Amount } \\
\text { (000MT) }\end{array}$ & $\begin{array}{c}\text { Share } \\
(\%)\end{array}$ \\
\hline
\end{tabular}

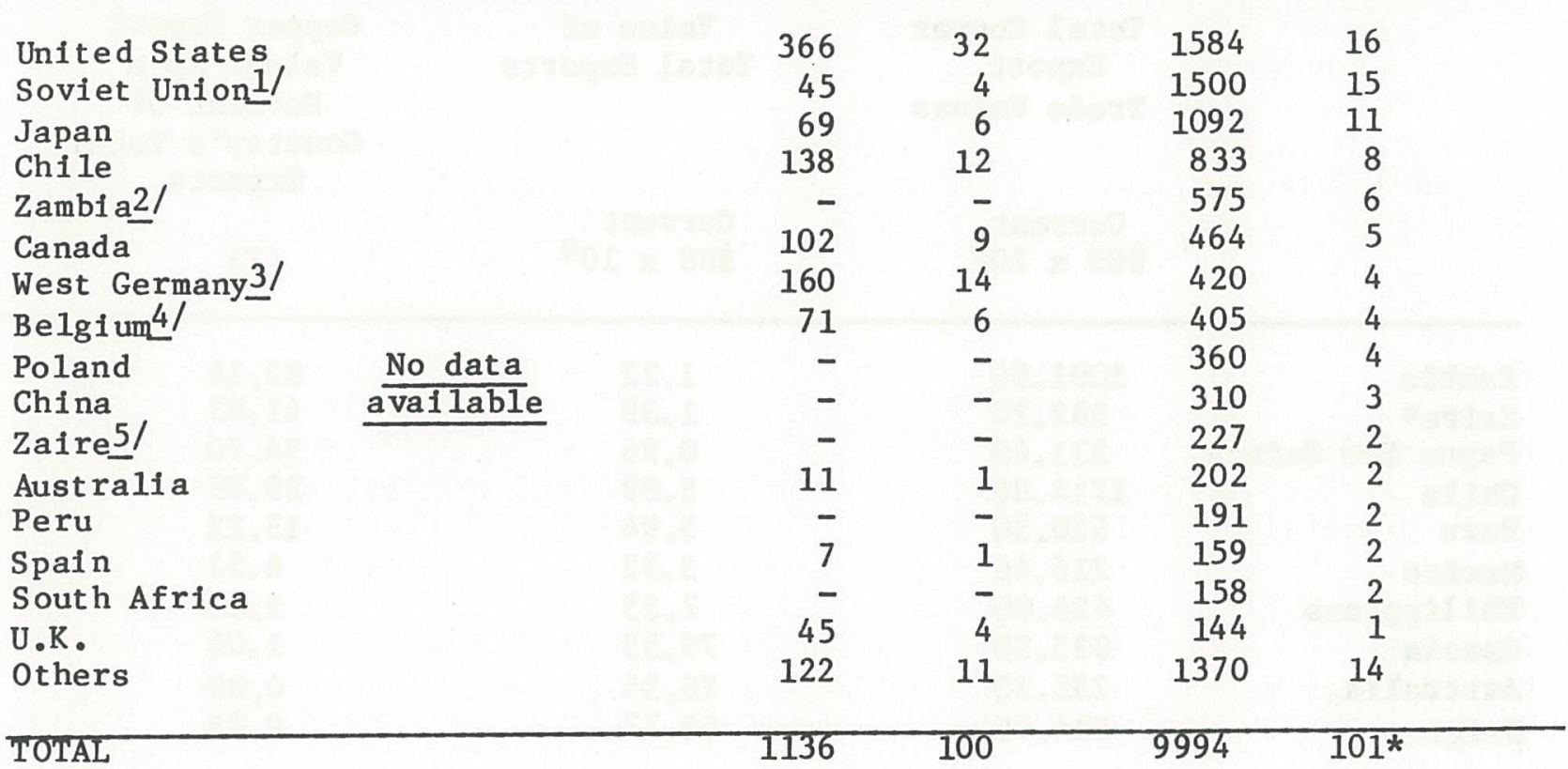

Notes:

$1 /$ Russia before 1983.

2/ Zambia

$3 /$ Includes East Germany in 1933.

$\frac{4}{5}$ Includes Luxembourg.

$\underline{5} /$ Zaire

Source: Metallgesellschaft, 1910, 1936, 1984.

*Columns may not total 100 due to rounding error. 
Figure VIII-13: COPPER EXPORTS AS A PERCENT OF TOTAL EXPORTS: 1981

$\begin{array}{ccc}\begin{array}{c}\text { Total Copper } \\ \text { Export }\end{array} & \begin{array}{c}\text { Value of } \\ \text { Trade Values }\end{array} & \begin{array}{c}\text { Copper Export } \\ \text { Values as a } \\ \text { Percent of } \\ \text { Country's Total } \\ \text { Exports }\end{array} \\ \begin{array}{c}\text { Current } \\ \text { \$US } \times 10^{6}\end{array} & \begin{array}{l}\text { Current } \\ \text { \$US } \times 10^{9}\end{array} & \text { (\%) }\end{array}$

\begin{tabular}{lrrr}
\hline Zambia & 1001.80 & 1.22 & 82.14 \\
Zaire* & 582.20 & 1.39 & 41.83 \\
Papua New Guinea & 331.40 & 0.96 & 34.70 \\
Chile & 1714.80 & 5.89 & 29.09 \\
Peru & 520.30 & 3.94 & 13.22 \\
Mexico & 216.40 & 3.32 & 6.51 \\
Philippines & 426.00 & 7.35 & 5.80 \\
Canada & 835.30 & 79.55 & 1.05 \\
Australia & 235.50 & 26.35 & 0.89 \\
Belgium & 534.40 & 62.77 & 0.85
\end{tabular}

*Data for 1980 .

Source: World Bank, 1983; Census Bureau, 1983. 
Figure VIII-14: - COPPER EXPORTS AS A PERCENT OF GNP: 1981

Total Copper Export Trade Values Current \$US $\times 106$

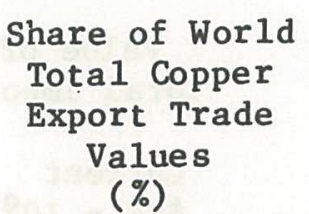

(\%)
Gross National
Product

Current

\$US $\times 10^{9}$
Copper Export Trade Values as a \% of GNP

(\%)

\begin{tabular}{lrrrr}
\hline Zambia & 1001.80 & 11.88 & 3.14 & 31.93 \\
Papua New Guinea & 331.40 & 3.93 & 2.41 & 13.76 \\
Zaire & 582.20 & 6.90 & 5.14 & 11.33 \\
Chile & 1714.80 & 20.33 & 31.44 & 2.45 \\
Peru & 520.30 & 6.17 & 21.92 & 1.37 \\
Belgium & 534.40 & 6.34 & 46.93 & 1.11 \\
Philippines & 426.00 & 5.05 & 38.37 & 0.30 \\
Canada & 835.30 & 9.91 & 274.75 & 0.23 \\
South Africa & 190.40 & 2.26 & 82.68 & 0.15 \\
Malaysia & 36.10 & 0.43 & 24.07 & \\
& & & \\
*1980 Data on GNP & & & & \\
Source: World Bank, 1983; Census Bureau, 1983; UNCTAD, 1984.
\end{tabular}


Figure VIII-15: COPPER IMPORTS AS A PERCENT OF TOTAL IMPORTS: 1981

$\begin{array}{lc}\begin{array}{c}\text { Total Copper } \\ \text { Import }\end{array} & \begin{array}{c}\text { Value of } \\ \text { Total Imports } \\ \text { Trade Values } \\ \text { Current }\end{array} \\ \begin{array}{l}\text { \$US } \times 106 \\ \text { Current }\end{array}\end{array}$

Belgium

Japan

China

Brazi 1

Argent ina*

Romania

South Korea

Yugoslavia

India

West Germany

It aly

939.80
2290.20
294.90
295.80
56.80
127.20
250.10
131.60
108.30
1127.90
575.00

66.72

165.28

22.70

25.77

5.82

13.46

28.38

17.38

16.82

197.17

100.82

\author{
Copper Import Values \\ As a Percent of \\ Country's Total Imports
}

(\%)

*Dat a for 1980.

Source: World Bank, 1983; Census Bureau, 1983. 
Figure VIII-16: COPPER IMPORTS AS A PERCENT OF GNP: 1981

Total Copper
Import
Trade Values
Current
\$US $\times 10^{6}$

Belgium

South Korea

Japan

Yugoslavia

West Germany

It aly

Romania

Sweden

France

Finland

Share of World
Total Copper
Import Trade
Values
$(\%)$

9.70
2.58
23.64
1.36
11.64
5.94
1.31
1.64
7.45
0.60

Gross National

Product

Current

\$US $\times 10^{9}$
Copper Import Trade Values as a \% of GNP

(\%)

*1980 Data from 1980.

Source: World Bank, 1983; UNCTAD, 1984; Census Bureau, 1983. 
Figure VIII-17: BALANCE OF VALUE TRADE IN COPPER: 1981

Value of

Tota 1 Copper

Export Trade

Current

\$US $\times 106$
Value of

Total Copper

Import Trade

Current

\$US $\times 10^{9}$
Net Value Trade

Balance in Copper

Current

\$US $\times 106$

\begin{tabular}{l} 
Surplus \\
\hline Chile \\
Zambia \\
Canada \\
Zaire \\
Peru \\
Philippines \\
Papua New Guine \\
Poland \\
Australia \\
Mexico \\
Deficit \\
Brazil \\
China \\
Belgium \\
United Kingdom \\
Italy \\
United States \\
France \\
West Germany \\
Japan
\end{tabular}

$$
\begin{array}{r}
1714.80 \\
1001.80 \\
835.30 \\
582.20 \\
520.30 \\
426.00 \\
331.40 \\
252.30 \\
235.50 \\
216.40
\end{array}
$$

$$
\begin{array}{r}
16.10 \\
3.40 \\
534.40 \\
45.20 \\
13.50 \\
276.10 \\
40.20 \\
175.60 \\
80.50
\end{array}
$$

0.00

0.00

68.30

0.00

0.00

12.10

0.00

0.00

14.00

6.00

295.80

294.90

939.80

510.20

575.00

860.70

721.50

1127.90

2290.20
1714.80

1001.80

767.00

582.20

520.30

413.90

331.40

252.30

221.50

210.40

$$
\begin{array}{r}
-279.70 \\
-291.50 \\
-405.40 \\
-465.00 \\
-561.50 \\
-584.60 \\
-681.30 \\
-952.30 \\
-2209.70
\end{array}
$$

Source: UNCTAD, 1984. 
Figure VIII -18: NET TRADE FLOWS: REFINED COPPER: 1973, 1978, 1983

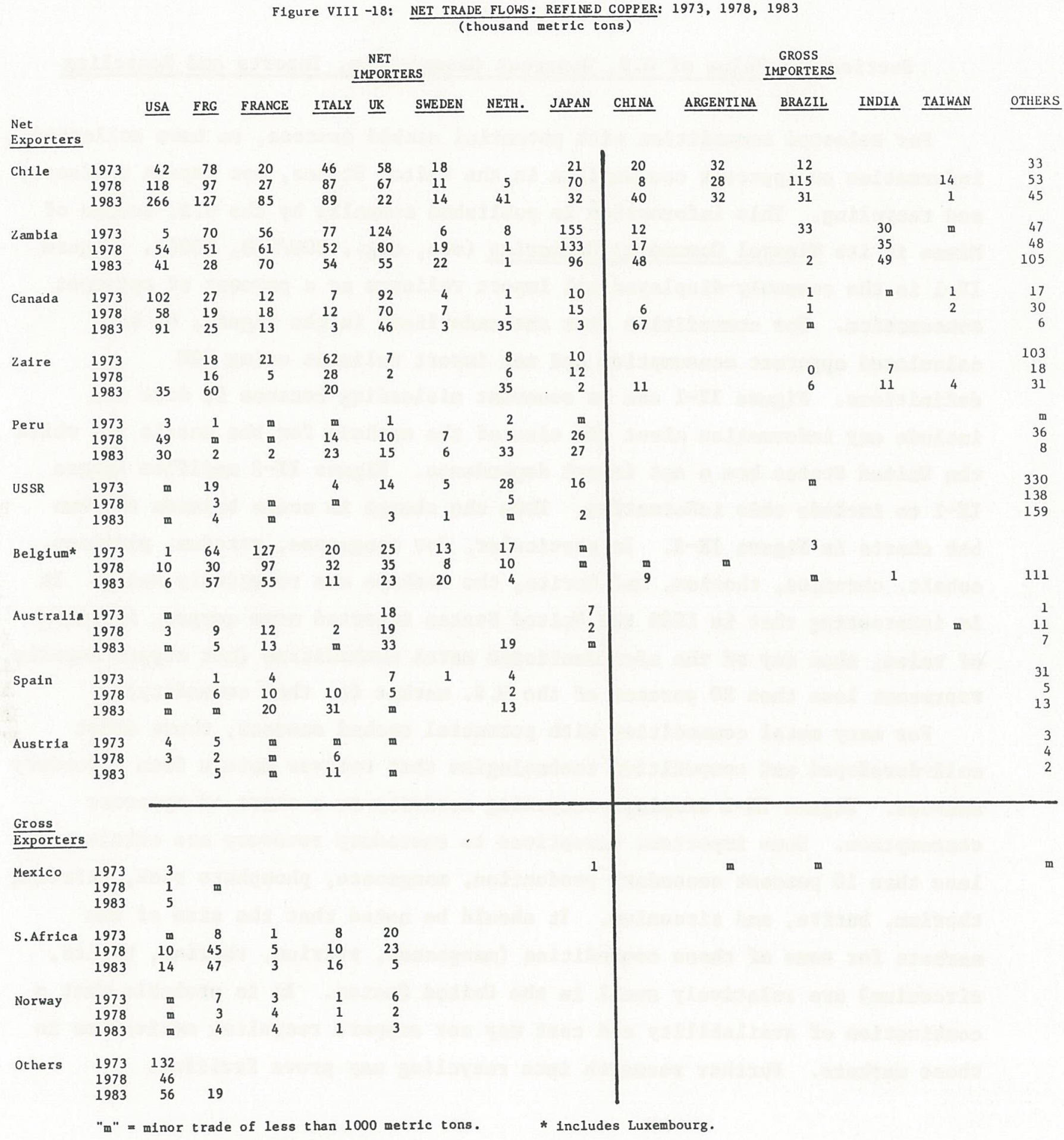

Source: Metallgesellschaft, 1984. 
Section IX: Value of U.S. Apparent Consumption, Imports and Recycling

For selected commodities with potential seabed sources, we have collected information on apparent consumption in the United States, net import reliance, and recycling. This information is published annually by the U.S. Bureau of Mines in its Mineral Commodity Summaries (see, e.g., BOM/MCS, 1986). Figure IX-1 is the commonly-displayed net import reliance as a percent of apparent consumption. For commodities that are underlined in the figure, we have calculated apparent consumption and net import reliance using BOM definitions. Figure IX-1 can be somewhat misleading because it does not include any information about the size of the markets for the metals for which the United States has a net import dependence. Figure IX-2 modifies Figure IX-1 to include this information. Note the change in scale between the two bar charts in Figure IX-2. In particular, for manganese, yttrium, platinum, cobalt, chromite, thorium, and barite, the markets are relatively small. It is interesting that in 1986 the United States imported more copper, in terms of value, than any of the aforementioned metal commodities (net copper imports represent less than 30 percent of the U.S. market for that commodity).

For many metal commodities with potential seabed sources, there exist well-developed and competitive technologies that recover metals from secondary sources. Figure IX-3 displays recycling activity as a share of apparent consumption. Some important exceptions to secondary recovery are cobalt, with less than 10 percent secondary production, manganese, phosphate rock, yttrium, thorium, barite, and zirconium. It should be noted that the size of the markets for some of these commodities (manganese, yttrium, thorium, barite, zirconium) are relatively small in the United States. It is probable that a combination of availability and cost may not support recycling activities in these markets. Further research into recycling may prove fruitful. 
Figure IX-1

1986 Nef Import Reliance As A Percent Of Apparent Consumption U.S. Bureau Of Mines

Net Import Rellance

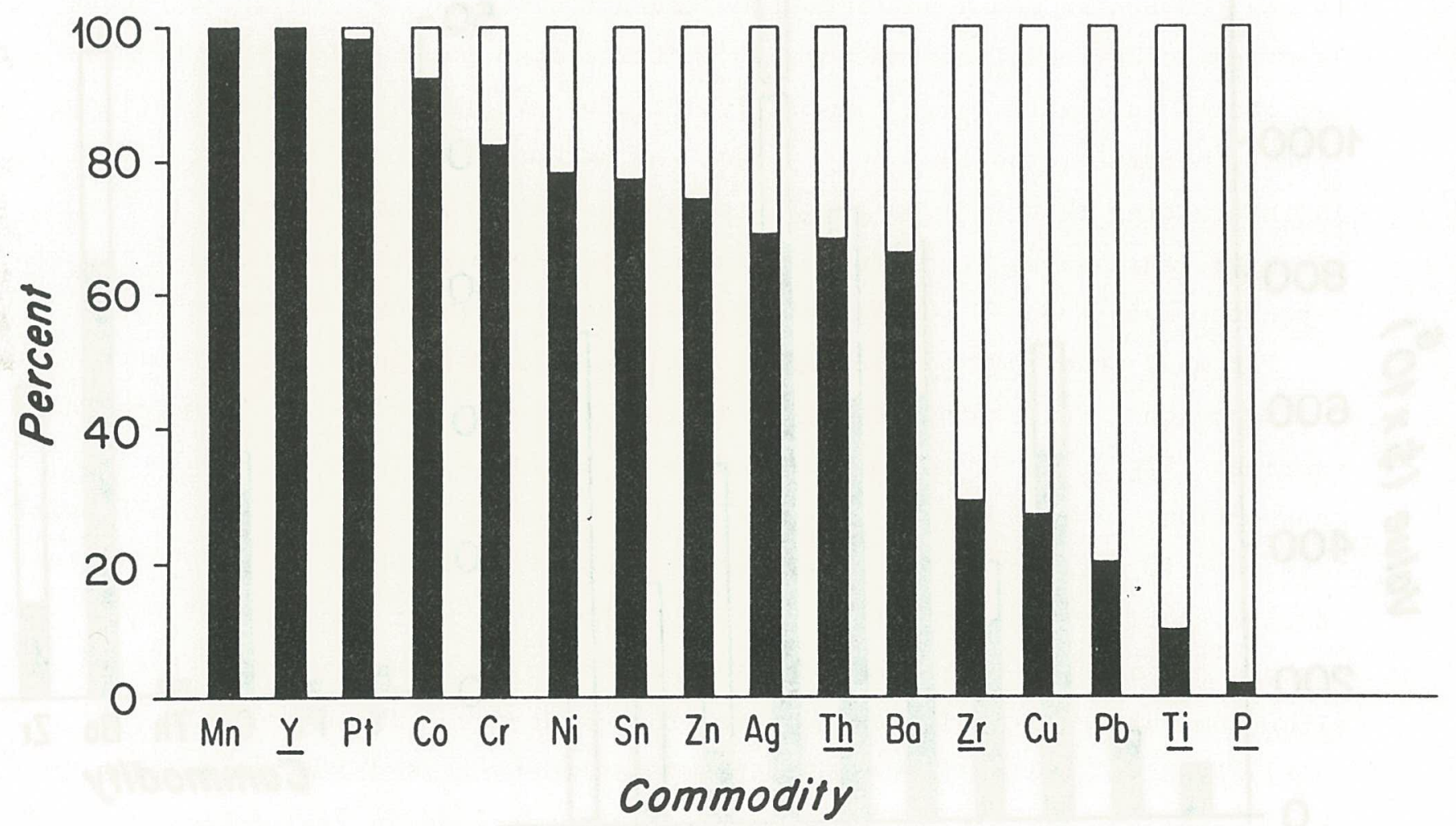


Figure IX-2: Apparent Consumption And Net Import Reliance In The United States: 1986

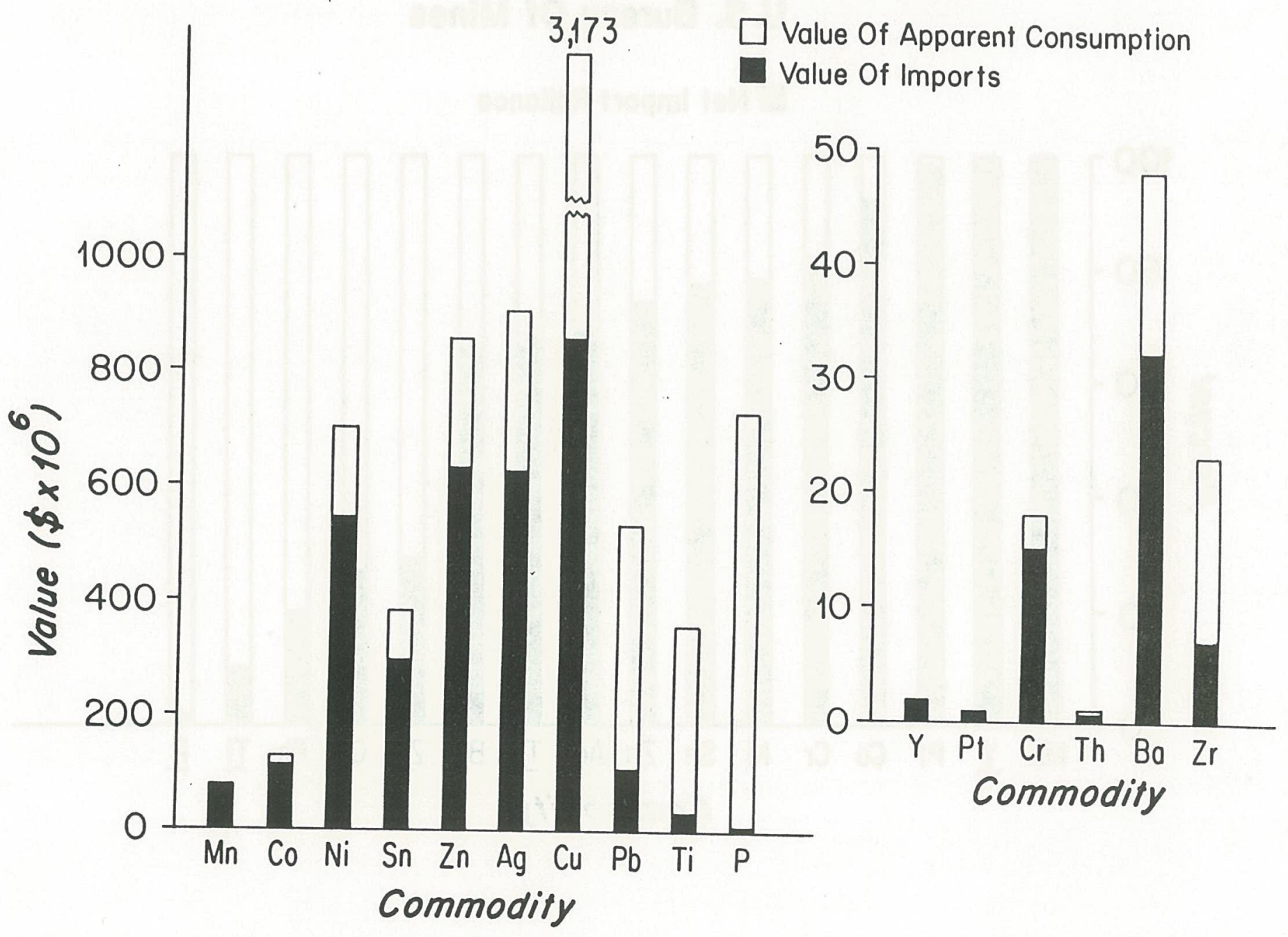


Figure IX-3

Value Of Apparent Consumption And Recycling In U.S. 1985

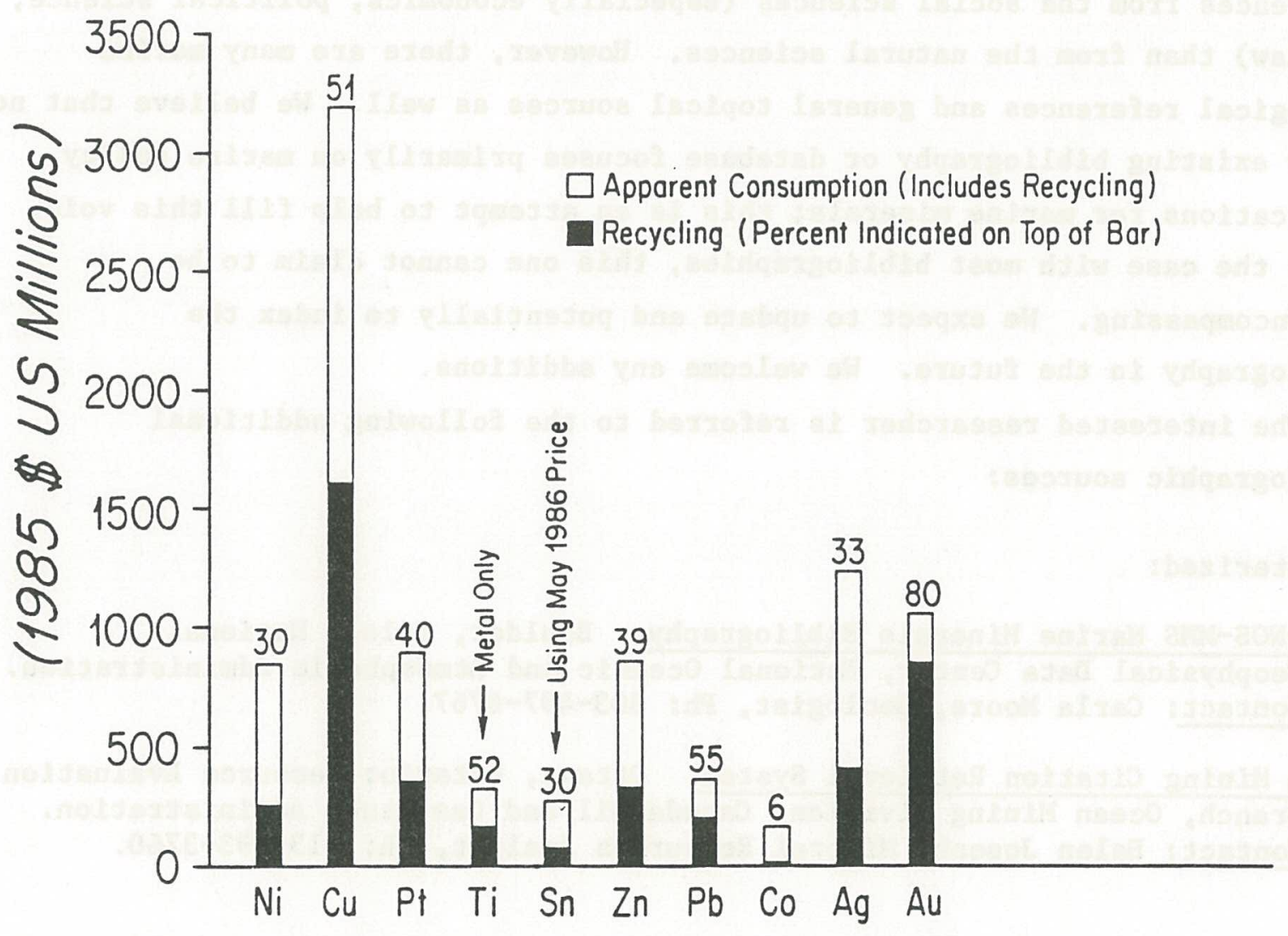


Section X: Bibliography of Marine Minerals and Public Policy

This section presents a selected bibliography of roughly 1300 references pertaining to marine minerals, oriented toward references in marine policy. Because marine policy is a multidisciplinary field, publications from several academic disciplines are included. More attention was given to selecting references from the social sciences (especially economics, political science, and law) than from the natural sciences. However, there are many marine geological references and general topical sources as well. We believe that no other existing bibliography or database focuses primarily on marine policy publications for marine minerals; this is an attempt to help fill this void. As is the case with most bibliographies, this one cannot claim to be al1-encompassing. We expect to update and potentially to index the bibliography in the future. We welcome any additions.

The interested researcher is referred to the following additional bibliographic sources:

Computerized:

NGDC-NOS-MMS Marine Minerals Bibliography. Boulder, Co1o.: National Geophysical Data Center, National Oceanic and Atmospheric Administration. Contact: Carla Moore, Geologist, Ph: 303-497-6767.

Ocean Mining Citation Retrieval System. Ottawa, Ontario: Resource Evaluation Branch, Ocean Mining Division, Canada Oil and Gas Lands Administration. Contact: Helen Joseph, Mineral Resources Analyst, Ph: 613-993-3760.

Printed:

Witkor, C.L. and L.A. Foster (eds.) 1980-1987. Marine Affairs Bibliography. Part Two: Law of the Sea, Section IX. Marine Resources: Nonliving. Halifax, Nova Scotia: Dalhousie Law School.

Avery, D. 1986. Ocean Mining References. Preliminary Reference List. Spokane, Wash.: Western Field Operations Center, U.S. Bureau of Mines.

Bulletin Germinal. 1982-Present? Nouvelles de 1'Activité Miniière en Mer. Orleans, France: GERMINAL.

Office of the Special Representative of the Secretary General for the Law of the Sea. 1985. Law of the Sea: A Select Bibliography. LOS/LIB/1. New York: United Nations. 
Office of Coastal and Resource Management. 1985. Summary of Ocean Minerals Activity and Related Research. Washington: National Oceanic and Atmospheric Administration.

Office of Ocean Minerals and Energy. 1984. Literature on Deep Seabed Mining Supported or Written by NOAA. Washington: National Oceanic and Atmospheric Administration.

Hawaii Department of Planning and Economic Development. 1981. Bibliography and Index to Literature on Manganese Nodules (1861-1979). Honolulu: State of Hawaii.

Earney, F.C.F. 1980. Petroleum and Hard Minerals from the Sea. New York: John Wiley and Sons, pp. 261-281. (The reference section contains 592 sources.)

Environmental Data Service. 1978. Marine Mining. Packaged Literature Search 78-2. First Edition. Washington: National Oceanic and Atmospheric Administration.

Moncrieff, A.G. and D.P.P. Baker. 1977. Sources of Information on Manganese Nodules. London: Consolidated Gold Fields.

Glasby, G.P. and G.L. Hubred. 1976. "Comprehensive Bibliography of Marine Manganese Nodules." New Zealand Oceanographic Institute Mem. 71..

Glasby, G.P. 1972. "Selected Bibliography of Marine Manganese Nodules." New Zealand Oceanographic Institute Record 1(2): 5-35.

Ocean Studies Program. 1971. Ocean Affairs Bibliography. Washington: Woodrow Wilson International Center for Scholars. 


\section{Bibliography of Marine Minerals and Public Policy}

Adams, F.G. 1982. Impact of Sea-Bed Minera1s on the World Economy. Unpublished manuscript. New York: Ocean Economics and Technology Branch, Department of International and Social Affairs, United Nations.

Adams, F.G. 1980. "The Law of the Sea Treaty and the Regulation of Nodule Exploitation." Journal of Policy Mode1ing 2(1): 19-33.

Adams, M.V. et a1. 1975. Mineral Resource Management of the Outer Continental She1f. Geological Survey Circular 720. Reston, Va.: U.S. Geological Survey.

Adelman, K. et a1. 1983. Energy Resources in an Uncertain Future. Cambridge, Mass.: Ballinger.

Agency of Industrial Science and Technology. 1982. National Research and Development Program (Large-Scale Project). Tokyo: Ministry of International Trade and Industry.

Agnew, A.F. 1983. Internationa1 Minera1s: A Nationa1 Perspective. AAAS Selected Symposium 90. Boulder, Colo.: Westview Press.

"Agreement Concerning Interim Arrangements Relating to Polymetallic Nodules of the Deep Sea Bed." 1982. International Legal Materia1s 21: 950-962.

Aidlin, J.W. 1974. "Representing the Geothermal Resources Client." Rocky Mountain Minera1 Law Institute 19: 27-46.

Aiton, A.S. 1924. "The First American Mining Code." Michigan Law Review 23: $105-113$.

Albers, J.P. 1973. "Seabed Mineral Resources: A Survey." Bulletin of the Atomic Scientists 29(8): 33-38.

Amacher, R.C. and R.J. Sweeney. 1976. "International Commodity Carte1s and the Threat of New Entry: Implications of Ocean Mineral Resources." Kyklos 29: 292-309.

Amann, H. 1983. "The Atlantis II Deep Project in the Red Sea as a Source of Technology for the Development of Marine Polymetallic Sulfides." Proc. Oceans '83. San Francisco.

Amann, H. 1982. "Technological Trends in Ocean Mining." Phil. Trans. Royal Society of London A 307: 377-403.

Amann, H. 1974. "Erode1- Und Erdgasgewinnung Aus Groesseren Wassertiefen: Entwicklungstendenzen, Aufschluss- Und Produktionstechnische Probleme." Zeit-Schrift fuer Bohr und Foerder Technik 90: 14-25. 
Amann, H. 1973. "Moeglichkeiten Zur Optimalen Schiffszeitnutzung Bei Der Marinen Grossflaechenprospektion." Meerestechnik 4: 109-113.

Amann, H. 1973. "Principles for an International Organization to Explore and Utilize Deep Ocean Mineral Resources." Marine Technology 4(5): 159-160.

Amann, H., H. Bäcker and E. Blissenbach. 1973. "Metalliferous Muds of the Marine Environment." Proc. Fifth Offshore Technology Conference, Vo1. 2. Houston, Tex., 345-358.

American Bar Association. 1969. Non-Living Resources of the Sea; A Summary and Critique of Chapter 4, Part III, of the Report of the Marine Science Commission. Joint report of the Section of International and Comparative Law, the Section of Natural Resources Law, and the Standing Committee on World Order under Law of the American Bas Assocition. Revised draft. Chicago.

American Petroleum Institute. 1987. Basic Petroleum Data Book. Washington.

Amin, S.H. 1981. "The Deep Seabed Mining Bill 1981: Economic Interests and International Law." Journal of the Law Society of Scotland 26: 255-256.

Amos, A.F. and 0.A. Roels. 1977. "Environmental Aspects of Manganese Nodule Mining." Marine Policy 1(2): 156-63.

Anand, R.P. 1975. Legal Regime of the Sea-Bed and the Developing Countries. Columbia, Mo.: South Asia Books.

Anderson, R.C. 1976. "Federal Mineral Policy: The General Mining Law of 1872." Natural Resources Journa1 16: 601-619.

Andrassy, J. 1968. "The Exploitation of Deep Sea Resources." Jugoslovenska Revija Za Medvnarodno Pravo: 98-110.

Andresen S. and S. Kingstad. 1980. "Economics and Politics of the Deep Oceans--Considerations on Ocean Mining at the Beginning of the 1980s." Internasjonal Politikk 1: 45-70.

Andrews, B.V. 1978. Relative Costs of U.S. and Foreign Nodule Transport Ships. Contract report. Rockville, Md.: Office of Marine Minerals, NOAA, U.S. Department of Commerce.

Andrews, B.V., J.E. F1ipse and F.C. Brown. 1983. The Economic Viability of a Four-Metal Pioneer Deep Ocean Mining Venture. TAMU-SG-84-201. College Station, Tex.: Texas A\&M University Sea Grant College Program.

Andrews, W.P. Jr. 1974. "Manganese Nodules and International Law." S.W. Wurfel (ed.). Emerging Ocean Oil and Mining Law. Sea Grant Publication UNC-SG-74-02. Chape1 Hill: University of North Carolina School of Law, pp. $30-39$.

Anon. 1985. "Tables, Nonliving Resources." Ocean Yearbook 5: 493-499. 
Anon. 1985. "JEFERAD: A Proposal for a Joint Enterprise for Exploration, Research and Development." (U.N. Document LOS/LCN/SCN.2/L.2) Ocean Yearbook 5: 364-382.

Anon. 1985. "Exchange Between Expert Pane1 and Reagan Administration Officials on Non-Seabed-Mining Provisions of LOS Treaty." American Journal of Internationa1 Law 79(1): 151-58.

Anon. 1984. "Alaskan P1acer and Lode Gold Operations Still Going Strong." North American Gold Mining Industry News, August 17, 1984, p. 7.

Anon. 1984. "Sea Riches: What Future?" World Press Review (November): 23-25.

Anon. 1984. "Provisiona1 Understanding Regarding Deep Seabed Matters." Environmental Policy and Law 13: 125-126.

Anon. 1984. "Commission Studies Sea-Bed Mining Rules: 'Pioneer Investor" Arrangements a Main Issue." U.N. Chronicle 21(4): 44-50.

Anon. 1981. "Deep Seabed Mining Workshop: Interim Report and Recommendations." Environmenta1 Policy and Law 7: 40-41.

Anon. 1981. "Group of 77: Seabed and Ocean F1oor Exploration and Exploitation: Legal Position." Environmenta1 Policy and Law 7: 33-35.

Anon. 1981. "USA: Access to Seabed Minerals Under the Draft Convention on the Law of the Sea." Environmental Policy and Law 7: 39-40.

Anon. 1980. 'L'Exploitation des Nodules Sous-Marins et sa Rentabilité Economique." Problemes Economiques (November): 21-25.

Anon. 1980. "United States Government Takes Steps to Exploit Seabed Minera1s." Chemical Engineering 87(14): 78.

Anon. 1976. "An Illusion of Camelot, the Validity of a Claim, and the Consequences of the Negotiations: The Great Nodule Spectacle." San Diego Law Review 13(3): 667-706.

Anon. 1976. "Deepsea Ventures: Exclusive Mining Rights to the Deep Seabed As a Freedom of the Sea." Baylor Law Review 28(1): 170-186.

Anon. 1976. "Ocean Mining Viable Economically." Metallurgia and Metal Forming 43(9): 267 .

Anon. 1975. "Deepsea's Adventures: Grotius Revisited." The Internationa1 Lawyer 9: 271-281, 751-753.

Anon. 1975. "Economic Significance in Terms of Sea-Bed Mineral Resources, of the Various Limits Proposed for National Jurisdiction." Ocean Management 2: 249-259.

Anon. 1975. "A Symposium on Deep Seabed Mining." Virginia Journal of International Law 15(4): 791-957. 
Anon. 1975. "Toward a Legal Regime for the International Seabed: The Soviet Union's Evolving Perspective." Virginia Journal of International Law 15: 871-901.

Anon. 1974. Ferromanganese Deposits of the Ocean Floor. Hawaii: University of Hawaii, Institute of Geophysics, 249 .

Anon. 1974. "Integrative Potential of the Proposed International Regime for the Seabed." Iowa Law Review 60: 148-173.

Anon. 1973. The Science and Technology of Utilizing the Bottom Resources of the Continental Shelf. University of New Hampshire Sea Grant Program Report UNH-SG-102.

Anon. 1973. "Guarding the Treasures of the Deep: The Deep Seabed Hard Minera1 Resources Act." Harvard Journal on Legislation 10: 596-620.

Anon. 1973. "United Nations Conference on Trade and Development: Seabed Mining." Bulletin of Legal Developments 17: 8-9.

Anon. 1971. "Lega1 Aspects of Seabed Petroleum and Minera1 Resource Development - The Draft United Nations Convention on the International Seabed Area and the United States Working Paper Submitted to the United Nations Seabed Committee. United States Proposal for Legal Regulation of Seabed Minera1 Exploitation Beyond National Jurisdiction." Natural Resources Lawyer 4: 569 .

Anon. 1971. "Ocean Mining Comes of Age." Parts 1, 2. Oceanology International (November): 34-41, (December): 33-38.

Anon. 1970. "Comprehensive Outline of the Scope of the Long-Term and Expanded Programme of Oceanic Exploration and Research." In United Nations Educationa1, Scientific and Cultural Organization. Intergovernmenta1 0ceanographic Commission Technica1 Series No. 7. New York: United Nations.

Anon. 1970. "Beach Mining." S.A. Mining and Engineering Journa1 81(4016): 172.

Anon. 1969. "Ceylon--Beach Sand Mining Grows--Rutile and Zircon Soon For Export." World Mining 5(7): 121 .

Anon. 1969. "Marine Mineral Exploration and Speculative Leasing Continue World-Wide." Undersea Technology 10(1): 62-65.

Anon. 1969. "Non-Living Resources of the Sea. A Critique." Natural Resources Lawyer 2(4): 409-439.

Anon. 1969. "The Status of Mineral Resources on the Ocean Floor." California Western Law Review : 299-312.

Anon. 1969. "United Nations General Assembly Resolution on Reservation of Sea-Bed and Ocean Floor for Peaceful Purposes, December 21, 1968." International Legal Materials 3: 201-208. 
Anon. 1968. "Economics, Not Technology, Will Spur Development of Ocean's Resources." Chemica1 and Engineering News 46(32) 18-19.

Anon. 1968. "Deposits of Black Sands Off California-Oregon Coast to be Drilled." Mining Congress Journa1 54(9): 22.

Anon. 1967. "U.S. Hits Move to Give U.N. Control of Subsea Minerals." Oil and Gas Journal 65(39): 77.

Anon. 1965. "Offshore Mining Paves the Way to Ocean Mineral Wea1th." Engineering and Mining Journal 5: 124-132.

Anstett, T.F., D.I. Bleiwas and C. Sheng-Fogg. 1982. Platinum Availability-Market Economy Countries. IC 8897. Washington: Minera1s Availability Program Appraisal, U.S. Bureau of Mines.

Antrim, L.N. and J.K. Sebenius. 1983. "Incentives for Ocean Mining Under the Convention". In B.H. Oxman et al. (eds.) Law of the Sea: U.S. Policy Dilemma. San Francisco, pp. 79-99.

Antrim, L.N., P.L. Spencer and W.W. Woodhead. 1979. Coba1t, Copper, Nicke1 and Manganese: Future Supply and Demand and Implications for Deep Seabed Mining. Washington: Office of Ocean, Resource and Scientific Policy Coordination, U.S. Department of Commerce.

Archer, A.A. 1983. "Marine Minera1 Resources--Effect of the Law of the Sea Convention." Resources Policy 9(1): 23-32.

Archer, A.A. 1976. "Prospects for the Exploitation of Manganese Nodules: The Main Technica1, Economic and Lega1 Problems." CCOP/SOPAC Technical Bulletin 2: 21-38.

Archer, A.A. 1973. "Economics of Off-Shore Exploration and Production of Solid Minerals on the Continental Shelf." Ocean Management 1: 5-40.

Archibald, C.R. and W.J. Barbour. 1978. Current Concerns in Mineral Policy. Kingston, Ont.: Center for Resource Studies, Queen's University.

Arnold, F. 1980. "Toward a Principled Approach to the Distribution of Global Wealth: An Impartial Solution to the Dispute Over Seabed Manganese Nodules." San Diego Law Review 17: 557-589.

Arrow, D.W. 1984. "Seabeds, Sovereignty and Objective Regimes." Fordham International Law Journal 7: 169-243.

Arrow, D.W. 1982. "The 'Alternative' Seabed Mining Regime: 1981." Fordham Internationa1 Law Journa1 5: 1-34.

Arrow, D.W. 1981. "The Customary Norm Process and the Deep Seabed." Ocean Development and International Law 9: 1-59.

Arthur D. Little, Inc. 1984. Technical and Cost Analyses of Manganese Nodule Processing Techniques and Their Significant Variations. U.S. Department of Commerce: Washington, D.C. 
Askevold, G. 1969. "Ocean Mining in Perspective." Stanford Journal of International Studies 4: 115-142.

Asthana, V. 1980. "Mineral Resources of the Continental Margins: An Introduction." In R.P. Anand (ed.) Law of the Sea: Caracas and Beyond, pp. 71-81.

Atkinson, T. 1972. "Underwater Development and Offshore Mining." Offshore Technology 4(4): 17-18.

Attanasi, E.D. 1984. "Government Investment in Minera1 Resource Information on Leasable Public Lands: The Case of Strippable Coal." Resources and Energy 6: 41-59.

Auburn, F.M. 1982. "Nationa1 Deep Seabed Mining Regimes and Reciprocity." 0i1 \& Gas Law and Taxation Review 4: 125-135.

Auburn, F.M. 1973. "Some Legal Problems of the Commercial Exploitation of Manganese Nodules in the Pacific." Ocean Development and International Law Journa1 1(2): 185-200.

Auburn, F.M. 1972. "The Deep Seabed Hard Mineral Resources Bil1." San Diego Law Review 9(3): 491-513.

Auburn, F.M. 1971. "Internationa1 Seabed Area." Internationa1 and Comparative Law Quarterly 20: 173-194.

Auburn F.M. 1970. "Deep Sea Mining." American Bar Association Journa1 56: 975-976.

Austin, C.F. 1967. "In the Rock: A Logical Approach for Undersea Mining of Resources." Engineering and Mining Journa1 168(8): 82-88.

Australian Delegation to the Preparatory Commission on the Law of the Sea. 1986. The Enterprise: Economic Viability of Deep Sea-Bed Mining of Polymetallic Nodules. LOS/PCN/SCN.2/WP.10. New York: United Nations.

Bäcker, H. 1978. "Metalliferous Sediments in the Red Sea, Occurrence, Exploration and Resource Assessment." Proc. 1st International Seminar on Offshore Mineral Resources. Brest, France: GERMINAL and BRGM, October $23-27$.

Bäcker, H. and V. Marchig. 1983. "Sulfide Ores from the Deep-sea: The Research Programme GEOMETEP with R/V Sonne." Meerestechnische 14(4): 134-140.

Bailey, J. 1983. "The Future of Exploitation of the Resources of the Deep Seabed and Subsoil." Law and Contemporary Problems 46(2): 71-76.

Baldwin, W.L. 1984. The World Tin Market: Political Pricing and Economic Competition. Durham, N.C.: Duke University Press.

Bal1, M.S. 1981/82. "Good 01d American Permits: Madisonian Federalism on the Territorial Sea and Continental Shelf". Environmental Law 12: 623-678. 
Ballard, R.D. and J.L. Bischoff. 1983. "Assessment and Scientific Understanding of Resources in the EEZ." Proc. A National Program for the Assessment and Development of the Mineral Resources of the United States Exclusive Economic Zone. U.S. Geologica1 Survey Circular 929.

Balzer, S. 1986. Survey of Foreign Offshore Development Activities for Minerals Other Than Oil and Gas. Ottawa: Canada Oil and Gas Lands Administration.

Bandow, D. 1982. "Developing the Mineral Resources of the Seabed." Cato Journa1 2(3): 793-821.

Banks, F.E. 1973. The World Copper Market: An Economic Analysis. Cambridge, Mass.: Ballinger Publishing Co.

Banks, S.M. 1983. "Protection of Investment in Deep Seabed Mining: Does the United States Have a Viable Alternative to Participation in UNCLOS?" Boston University International Law Journal 2: 267-297.

Baram, M.S., D. Rice and W. Lee. 1978. Marine Mining of the Continental Shelf: Lega1, Technical and Environmental Considerations. Cambridge, Mass.: Ba11inger Publishing Company.

Barber, G.A. and S. Muessig. 1984. "Minera1s Exploration Statistics for the Years 1980, 1981, and 1982." Economic Geology 79: 1768-76.

Barkenbus, J.N. 1979. Deep Seabed Resources: Politics and Technology. New York: The Free Press--Macmillan.

Barkenbus, J.N. 1977. "Seabed Negotiations: The Failure of United States Policy." San Diego Law Review 14(3): 623-636.

Barkenbus, J.N. 1975. "Internationa1 Conflict Over Resources - Case of Manganese Nodules." Orbis 19(1): 185-99.

Barkenbus, J.N. 1974. "International Implications of Manganese Nodule Mining." World Affairs 136(4): 306-320.

Barnes, J.N. 1981. "Prevention and Control of Marine Pollution: Pollution from Deep Ocean Mining." In D.M. Johnston (ed.) The Environmental Law of the Sea, pp. 259-284.

Barsotti, A.F. 1984. "The Future Availability of Copper, Cobalt, Nickel and Manganese, Availability from Land-Based Endowments: A Perspective." Journal of Resource Management and Technology 13(2): 85-96.

Barsotti, A.F. 1984. "Copper, Cobalt, Nickel and Manganese, Availability from Land-Based Endowments: A Perspective." Natural Resources Forum.

Bartlett, P.M. 1986. Personal communication. Austin, Tex.: Dept. of Marine Studies, Univ. of Texas at Austin. December 11.

Bascom, W. 1967. "Mining the Ocean Depths." Geoscience News 1: 10-11, 26-28. 
Bates, R.L. and J.A. Jackson (eds.) 1984. Dictionary of Geological Terms. Third Edition. Prepared by the American Geological Institute. Garden City, NY: Anchor Press/Doubleday.

Baturin, G.N. 1972. Phosphorites on the Seafloor: Origin Composition and Distribution. New York: E1sevier Scientific Publishing Company.

Bea11, J.V. 1967. "Ocean Mining Faces Problems: Push in Oceanography May Yield Solutions." Mining Engineering 52-57.

Beauchamp R.G. and M.J. Cruickshank. 1984. "The Role of the Minerals Management Service in OCS Mining." Proc. Oceans '84. Washington: MTS and IEEE.

Beauchamp R.G. and M.J. Cruickshank. 1983. "Placer Minerals on the U.S. Continental Shelves--Opportunity for Development." Proc. Oceans '83. San Francisco: Marine Technology Society and Institute for Electrical and Electronics Engineers.

Beggson, A. and H.S. Levine. 1983. The Soviet Economy: Toward the Year 2000. Boston: Allen \& Unwin.

Bennett, E.F. 1966. "Public Land Policy: Reconciliation of Pub1ic Use and Private Development." Rocky Mountain Mineral Law Institute 11: 311.

Bennett, E.F. 1966. "Legal C1imate for Underseas Mining." Trans. Second Annual Marine Technology Society Conference, pp. 204-210.

Bentil, J.K. 1983. "The Foreshadowed Global Legal Regime of Deep Seabed Exploration and Mining." Lloyd's Maritime and Commercial Law Quarterly: 260-282.

Bergin, A. 1982. "Australia and Deep Seabed Mining." Australian Outlook $36(2): 45-50$.

Bergman, M.S. 1981. "The Regulation of Seabed Mining Under the Reciprocating States Regime." American University Law Review 30: 477-518.

Bernfeld, S.S. 1969. "The Mining Industry and the Continental Shelf Convention." Institute of Mining and Metallurgy 78: A10-A19.

Bernfeld, S.S. 1968. "Pitfalls and Panaceas for the Acquisition of Hard Rock Minera1s Beneath the High Seas." Rocky Mountain Mineral Law Institute 14: 613-641.

Berns, W. 1981. "Mining the Seas for a Brave New World." Regulation: 15-18.

Bezrukov, P.L. 1972. "Problems of Geological Investigation of Minera1 Resources of the Ocean." Oceanology 11(6): 803-811.

Biblowit, Charles E. 1983-84. "Deep Seabed Mining: The United States and the United Nations Convention on the Law of the Sea." St. John's Law Review 58: 267-305. 
Bieniewicz, D.J. and R.H. Nelson. 1983. "Planning a Market for Federal Coal Leasing." Natural Resources Journal 23: 593-604.

Biggs, G. 1980. "Deep Seabed Mining and Unilatera1 Legislation." Ocean Development and International Law 8(3): 223-257.

Birnie, P.W. 1981. "Interim Mining Legislation and UNCLOS III." Marine Policy 5(4): 334-335.

Bischoff, J.L. et a1. 1983a. "Sea-Floor Massive Sulfide Deposits from $21^{\circ} \mathrm{N}$, East Pacific Rise; Juan de Fuca Ridge; and Galapagos Rift: Bulk Chemical Composition and Economic Implications." Economic Geology 78(8): 1711-20.

Bischoff, J.L. et al. 1983b. "Geochemistry and Economic Potential of Massive Sulfide Deposits from the Eastern Pacific Ocean." USGS Open File Report 83-324. Menlo Park, Calif.: U.S. Geological Survey.

Bischoff, J.L. and D.Z. Piper (eds.) 1979. Marine Geology and Oceanography of the Pacific Manganese Nodule Province. New York: Plenum Press.

Bischoff, J.L. et al. 1976. "Deep Ocean Mining Environmental Study, N.E. Pacific Nodule Province, Site C, Geology and Geochemistry." USGS Open-File Report 76-548. Menlo Park, Calif.: USGS, U.S. Department of the Interior.

Björnsson, S., S. Arnorsson and J. Tomasson. 1972. "Economic Evaluation of Reykjanes Therma1 Brine Area, Iceland." AAPG Bulletin 56(12): 2830-2391.

Black, J.R.H., T.B. King and J.P. Clark. 1981. "An Analysis of 4 Processing Schemes for Recovering Metallic Values from Deepsea Nodules." Materials and Society 5(2): 191-209.

Bleicher, S.A. 1984. "The Law Governing Exploitation of Polymeta11ic Sulfide Deposits from the Seabed." In T. Buergenthal (ed.) Contemporary Issues in International Law: Essays in Honor of Louis B. Sohn, pp. 209-227.

B1eiwas, D.I. 1984. Nicke1 Availability--Market Economy Countries. IC 8995. Washington: Minerals Availability Progam Appraisal, U.S. Bureau of Mines.

B1issenbach, E. and Z. Nawab. 1982. "Metalliferous Sediments of the Seabed: The Atlantis-II-Deep Deposits of the Red Sea." Ocean Yearbook 3: 77-104.

Blood, D.M. and J.R. Davidson. 1984. Potential Fiscal Impacts of Manganese Nodule Processing in the Puna and Kohala Districts of Hawaii. UNIHI-SAEGRANT-ME-84-04. Honolulu: University of Hawaii Sea Grant College Program.

Bockstae1, N.E. and K.E. McConne11. 1980. "Measuring the Worth of Natura1 Resource Facilities: Reply." Land Economics 56(4): 487-490.

Bockstae1, N.E. and K.E. McConne11. 1980. "Calculating Equivalent and Compensating Variation for Natura1 Resource Facilities." Land Economics $56(1): 56-63$. 
Bohi, D.R. and M.A. Toman. 1983. "Understanding Nonrenewable Resource Supply Behavior." Science 219: 927-932.

Bolton, B.R., J. Ostwald and M. Monzier. 1986. "Precious Meta1s in Ferromanganese Crusts from the South-West Pacific." Nature 320: 518-520.

Bonatti, E. 1978. "The Origin of Metal Deposits in the Oceanic Lithosphere." Scientific American (February): 54-61.

Borgese, E.M. 1982. Ocean Mining and Developing Countries: An Approach to Technological Disaggregation. UNIDO/IS.345. New York: United Nations.

Borgese, E.M. and P.M.T. White (eds.) 1981. Seabed Mining: Scientific, Economic, Political Aspects: An Interdisciplinary Manual. Msida, Malta: International Ocean Institute.

Boskin, M.J. et al. 1985. "New Estimates of the Value of Federal Mineral Rights and Land." American Economic Review 75: 923.

Bosson, R. and B. Varon. 1977. "Objectives and Policies of Minera1 Sector Development". The Mining Industry and the Developing Countries. Chap. 6. New York: Oxford University Press for the World Bank.

Boström, K. et al. 1969. "Aluminum-Poor Ferromanganoan Sediments on Active Oceanic Ridges." Journal of Geophysical Research 74: 3261-3270.

Bouchez, L.J. 1984. "Offshore Mining: International Law Aspects." In E. Hey and A.W. Koers (eds.) The International Law of the Sea: Issues of Implementation in Indonesia, pp. 134-141.

Bouchez, L.J. 1984. "Offshore Mining: National Law Aspects." In E. Hey and A.W. Koers (eds.) The International Law of the Sea: Issues of Implementation in Indonesia, pp. 142-150.

Bouysse, P. 1970. "La Recherche Minière Sous-Marine." Annales des Mines 4: 41-52.

Bowen, R.E. 1985. "Law of the Sea Threatens Research." Nature 317(12): 123.

Bowen, R.E. 1986. "Scientific Value and Marine Polymetallic Sulfides: A Commentary." In R.B. Krueger and S.A. Riesenfeld (eds.) The Developing Order of the Oceans. Honolulu: University of Hawaii Press.

Bowen, R.E. and T.M. Hennessey. 1985. "Adjacent State Issues and the EEZ." Ocean Development and International Law 15(3/4):

Bowen, R.E. and T.M. Hennessey. 1985. "Strategic Tensions and Minerals Management: The Structure and Design of the International Seabed Authority." Paper presented to the World Congress of the International Political Science Association, Paris, France, 1985.

Bowen, R.E. and T.M. Hennessey. 1984. "U.S. EEZ Relations with Canada and Mexico." Oceanus 27(4): 41-47. 
Bradley, P.R. 1973. "Increasing Scarcity: The Case of Energy Resources." American Economic Review 63(2): 119-128.

Bragg, D. 1979. Gulf Coast Manganese Nodule Processing Plant Location Criteria. Contract report. Rockville, Md.: Marine Minera1s Division, NOAA, U.S. Department of Commerce.

Branco, R. 1973. "Rationa1 Development of Sea-Bed Resources: Issues and Conflicts." Ocean Management 1(1): 41-54.

Branco, R. 1973. "The Tax Revenue Potential of Manganese Nodules." Ocean Development and Internationa1 Law Journa1 1(2): 201-208.

Breaux, J.B. 1981. "Are There Alternatives to the Law of the Sea Treaty?" Transcript of ta1k presented 19 October 1981 before?

Breeden, R. 1976. "Federalism and Development of Outer Continenta1 Shelf Minera1 Resources." Stanford Law Review 28(6): 1107-59.

Breen, J.H. 1984. "The 1982 Dispute Resolving Agreement: The First Step Toward Unilateral Mining Outside the Law of the Sea." Ocean Development and Internationa1 Law 14: 201-233.

Brennan, K. 1984. "Australia and the Law of the Sea: The International Sea-Bed." In K.W. Ryan (ed.) International Law in Australia, pp. 419-438.

Brett, P.0. 1984. "Harvesting Polymeta11ic Nodules from the Seabed--A Technological Reality." Internasjonal Politikk 4: 113-18.

Brewer, W.C., Jr. 1985. "The Prospect for Deep Seabed Mining in a Divided World". Ocean Development and Internationa1 Law 14: 363-381

Brewer, W.C., Jr. 1982. "Deep Seabed Mining: Can An Acceptable Regime Ever Be Found?" Ocean Development and International Law 11: 25-67.

Bril1, R. 1968. "Arms Contro1 and Disarmament and the Mineral Resources of the Ocean." In E. Keiffer (ed.) Symposium Proceedings of Mineral Resources of the World Ocean. Narragansett Marine Laboratory Occasional Publication No. 4, pp. 102-103.

Briscoe, J. and J.L. Lambert. 1984. "Seabed Mineral Discoveries Within National Jurisdiction and the Future of the Law of the Sea." University of San Francisco Law Review 18: 433-487.

Briskey, J.A. and H. Wedow, Jr. 1983. "Zinc Resources." Encyclopedia of Materials Science and Engineering. Cambridge: Oxford Press.

British Sulphur Corporation Ltd. 1964. A World Survey of Phosphate Deposits. London.

Broadus, J.M. 1987. "Seabed Materia1s." Science 235(4791): 853-860.

Broadus, J.M. 1986. "Asian Pacific Marine Minerals and Industry Structure." Journal of Marine Resource Economics 3(1): 63-88. 
Broadus, J.M. 1985. Statement Concerning the Ocean Minerals Program. Testimony Before the Subcomittee on Oceanography, House Merchant Marine and Fisheries Committee. Washington: October 24.

Broadus, J.M. 1984. "Economic Significance of Marine Polymetallic

Sulfides." Proc. 2nd Internationa1 Seminar on Offshore Mineral

Resources. Brest, France: GERMINAL, pp. 560-576.

Broadus, J.M. 1984. Pacific Ferromanganese Oxide ("Coba1t") Crusts: Economic Prospects and Problems. Unpublished working paper. Woods Hole, Mass.: Marine Policy Center, Woods Hole Oceanographic Institution.

Broadus, J.M. 1980. An Analytic Study of Cyclical Behavior in Coal Markets. Lexington, Ky.: Institute for Mining and Minerals Research, University of Kentucky.

Broadus, J.M. and R.E. Bowen. 1986. "Developing a U.S. Research Strategy for Marine Polymetallic Sulfides." Ocean Development and International Law 17(1/2/3): 91-130.

Broadus, J.M. and R.E. Bowen. 1984. "Polymetallic Sulfides and Policy Spheres." Oceanus 27(3): 26-31.

Broadus, J.M. and R.E. Bowen. 1983. "Evaluating the Economic Significance of Polymetallic Sulfides Deposits." Proc. of the Offshore Technology Conference. Houston: May 2-5.

Broadus, J.M. and P. Hoagland. In press. "Marine Minerals and World Resources." In J.M. Broadus and A.G. Gaines (eds.) To Use the Oceans Wisely. Woods Hole, Mass.: Marine Policy Center, Woods Hole Oceanographic Institution.

Broadus, J.M. and P. Hoagland. 1984. "Rivalry and Coordination in Marine Hard Minerals Regulation." Proc. Oceans '84. Washington: Marine Technology Society and Institute for Electrical and Electronics Engineers.

Broadus, J.M. and P. Hoagland. 1984. "Conflict Resolution in the Assignment of Area Entitlements for Seabed Mining." San Diego Law Review 21: 541-576.

Brobst, D.A. 1986. "Review of 'Strategic Minerals, Volume I, Major Minera1-Exporting Regions of the Wor1d."' Economic Geology 81: 744-749.

Brobst, D.A. and W.P. Pratt. 1973. United States Mineral Resources. Geological Survey Professional Paper 820. Washington: U.S. Geologica1 Survey.

Brock, J. 1967. "Mineral Resources and the Future Development of the International Law of the Sea." JAG Journal 22: 39-49.

Brockhoff, K. 1984. "The Production Ceiling According to the United Nations Convention on the Law of the Sea." Weltwirtschaftliches Archiv.: 541-57. 
Brooke, R.L. 1984. "The Current Status of Deep Seabed Mining". Virginia Journa1 of International Law 24: 361-417.

Brookings Institution. 1977. The Future of Non-Fue1 Minera1s. Washington.

Brooks, D.B. 1968. "Deep Sea Manganese Nodules: From Scientific Phenomenon to Wor1d Resource." Natura1 Resources Journa1 8(Ju1y): 401-423.

Brooks, D.B. 1966. Low-Grade and Nonconventional Sources of Manganese. Baltimore: The Johns Hopkins Press for Resources for the Future.

Brooks, D.B. and P.W. Andrews. 1974. "Mineral Resources, Economic Growth, and World Population." Science 185(4145): 13-19.

Brooks, D.B. and B.S. Lloyd. 1968. "Mineral Economics and the Oceans." Proc. Symposium on Mineral Resources of the World Ocean. Occasional Publication No. 4, Kingston, R.I.: University of Rhode Island.

Brown, E.D. 1984. "Seabed Mining: From UNCLOS to PrepCom." Marine Policy 8: 151-164.

Brown, E.D. 1984. Sea-Bed Energy and Mineral Resources and the Law of the Sea. Vols. 1-3. London: Graham \& Trotman.

Brown, E.D. 1983. "Deep-Sea Mining: The Consequences of Failure to Agree at UNCLOS III." Natural Resources Forum 7: 55-70.

Brown, E.D. 1983. "Pollution from Seabed Mining: Legal Safeguards." Environmenta1 Policy and Law 10: 122-134.

Brown, E.D. 1969. "Deep-Sea Mining: The Legal Regime of 'Inner Space'." 1968 Yearbook of World Affairs 165-190.

Browning, D. 1969. "The Lega1 Environment for Deep Ocean Minera1 Development." Proc. Symposium on Private Investors Abroad. Dallas, Tex.: 9-54.

Browning, D. 1968. "Exploitation of Submarine Mineral Resources Beyond the Continental Shelf." Texas Internationa1 Law Forum 4: 1-27.

Brubaker, S. (ed.) 1984. Rethinking the Federal Lands. Resources for the Future: Washington, D.C.

Buckingham, D.A. and J.F. Lemons, Jr. 1984. Nicke1 Availability--Domestic. IC 8988. Washington: Minerals Availability Progam Appraisal, U.S. Bureau of Mines.

Bulkley, I.G. 1979. Who Gains from Deep Ocean Mining? Simulating the Impact of Regimes for Regulating Nodule Exploitation. Research Series No. 40. Berkeley, Calif.: Institute of International Studies, University of California at Berkeley.

Bullis, L.H. and J.E. Mielke. 1985. Strategic and Critical Materials. Boulder: Westview Press. 
Bureau of the Census. 1985. Statistica1 Abstract of the United States. Washington: U.S. Department of Commerce.

Bureau of the Census. 1982. Census of Mineral Industries. Washington: U.S. Department of Commerce.

Bureau of the Census. 1976. Historical Statistics of the United States. Washington: U.S. Department of Commerce.

Bureau of Industrial Economics. 1983. Market Trends and Forecasts for Selected Strategic Metals. Washington: U.S. Department of Commerce.

Bureau of Land Management. 1974. Draft Environmental Impact Statement: Proposed OCS Hard Minera1 Mining Operation and Leasing Regulations. U.S. Department of the Interior.

Bureau of Mines. 1987. An Economic Reconnaissance of Selected Sand and Gravel Deposits in the U.S. Exclusive Economic Zone. Open-File Report OFR 3-87. Washington.

Bureau of Mines. 1987. An Economic Reconnaissance of Selected Heavy Minera1 Placer Deposits in the U.S. Exclusive Economic Zone. Open-File Report OFR 4-87. Washington.

Bureau of Mines. 1987. Mineral Commodity Summaries. Annual Series Vols. 1954-1987. Washington. (BOM/MCS.)

Bureau of Mines and Basic Industries Sector, U.S. Department of Commerce. 1986. Domestic Consumption Trends, 1972-82, and Forecasts to 1993 for Twelve Major Metals. Open File Report 27-86. Washington: U.S. Department of the Interior.

Bureau of Mines. 1985, 1980, 1975, 1970. Mineral Facts and Problems. Washington. (BOM/MFP.)

Bureau of Mines. 1985. Project 2000: A Strategic Plan for the Bureau of Mines. Washington: U.S. Department of the Interior, pp. 42-48..

Bureau of Mines. 1984. Mineral Industries of Africa. Washington: U.S. Department of the Interior.

Bureau of Mines. 1981. Mineral Industries of Latin America. Washington: U.S. Department of the Interior.

Bureau of Mines. 1974. Minerals Yearbook. Volume 1: "Metals, Minera1s, and Fuels". Washington: U.S. Department of the Interior.

Burger, H., W. Ehrismann and W. Skala. 1980. "Aspects of the Statistical Analysis of Marine Ore Deposits." Mineralium Deposita 18: 335-350.

Burk, C.A. 1972. "Global Tectonics and World Resources." American Association of Petroleum Geologists Bulletin 56(2): 196-202. 
Burke, W.T. 1968. "A Negative View of a Proposal for United Nations Ownership of Ocean Mineral Resources." Natural Resources Lawyer 1(2): 42-62.

Burns, R.E. 1981. Summary of Minutes of the DOMES-Mining Industry Meeting, February 24, 1976. Report No. PB81-161473. Springfield, Va.: National Technical Information Service.

Burns, R.G. and M. Thonis. 1975. "Manganese Ore Deposits and Plate Tectonics." Nature 253(5493): 614-616.

Burroughs, T. 1984. "Ocean Mining: Boom or Bust." Technology Review (April): 55-60.

Burrows, J.C. 1980. "The Net Value of Manganese Nodules to US Interests With Special Reference to Market Effects and National Security." In Kildow, J.T. (ed.) Deepsea Mining. Cambridge, Mass.: MIT Press, 124-139.

Burton, S.J. 1977. "Freedom of Seas - Internationa1 Law Applicable to Deep Seabed Mining Claims." Stanford Law Review 29(6): 1135-80.

Buzan, B. 1974. "Seabed Issues at the Law of the Sea Conference: The Caracas Session." Canadian Yearbook of International Law 12: 222-238.

Callies, D.L. and C.J. Johnson. 1985. A Summary of Land and Environmental Laws and Business/Economic Factors Applicable to the Siting of a Manganese Nodule Processing Plant in the Pacific Basin/Rim: Australia, Canada, Colombia, Ecuador, Fiji and The Philippines. UNIHI-SG-CR-85-02.

Cameron, H. and J. Simnett. 1982. "International Cooperation in Ocean Mining: International Conference for Ocean Mining, Dusseldorf, West Germany, 15 May 1981." Marine Policy 6(2): 156-157.

Cameron, H. et a1. 1981. "The Economic Feasibility of Deep-sea Mining." Engineering Costs and Production Economics 5: 279-287.

Cameron, H. et a1. 1981. Manganese Nodule Mining: Issues and Perspectives. Manchester, U.K.: PREST, University of Wales Institute of Science and Technology.

Cameron, H. and L. Georghiou. 1981. "Production Limits: Who Benefits?" Marine Policy 5: 267-270.

Campbe11, G.A. 1986. "By-Product Metal Economics: A Mode1 of the U.S. Cadmium Market." Journal of Resource Management and Technology 14(3): 191-195.

Campbe11, H.E. 1980. Market Price of Risk in the Canadian Mining Industry. Kingston. Ont.: Center for Resource Studies, Queen's University.

Cann, J.R. 1980. "Availability of Sulphide Ores in the Ocean Crust." Journal of the Geological Society of London 137: 381-384. 
Capen, E.C., R.V. Clapp and W.M. Campbe11. 1971. "Competitive Bidding in High Risk Situations." Journal of Petroleum Technology 23: 641-651.

Capstaff, A.E., Jr. 1979. "Economic and Public Policy Issues in Deep Ocean Mineral Mining." Proc. Offshore Technology Conference. OTC 3454. Houston: $835-843$.

Carnegie Institution of Washington. 1983. The Problems and Prospects for Incorporating Geologic Information into the Long-Term Policymaking Process. Workshop Summary. Washington, D.C.

Caron, D.D. 1981. "Deep Seabed Mining: A Comparative Study of U.S. and West German Municipal Legislation." Marine Policy 5: 4-16.

Caron, D.D. 1980. "Municipal Legislation for Exploitation of the Deep Seabed." Ocean Development and International Law 8: 259-297.

Carpenter, G. et a1. 1987. Sulphur \& Salt Leasing: Summary of Issues. OCS Report MMS 87-0036. Reston: Minerals Management Service.

Carro11, B.L. 1974. "Federal Income Taxation--Jurisdiction Over Minera1 Operations in Continental Shelf Areas. Treas. Reg. 1.638 (1973)." Texas Internationa1 Law Journa1 9: 102-107.

Carter, L. 1968. "Deep Seabed: Who Should Control It? U.N. Asks." Science 159: 66-68.

Casciano, F.M. and R.Q. Palmer. 1969. Potential of offshore Sand as an Exploitable Resource in Hawaii. Honolulu: University of Hawaii Sea Grant Program.

Cathey, P.J. 1968. "Ocean Mining: Who'11 Pay the Bil1?" Iron Age 202:60-61.

Centre for Resource Studies. 1982. "Mineral Policy Formulation: The Role of Scientific and Technical Knowledge." Proc. Tenth CRS Policy Discussion Seminar. Kingston, Ont.

Centre for Resource Studies. 1982. "Current Concerns in Minera1 Policy." Proc. Fourth Annual Meeting CRS Advisory Council. Kingston, Ont.

Chacko, E. 1978. "The Economics of Deep Sea Nodules: An Appraisal of Recent Estimates." Natura1 Resources Forum 2(2): 133-146.

Chanslor, J.W. 1974. Treasure from the Sea. Washington: Hydrographic Center, Navigational Information Services Division, U.S. Defense Mapping Agency.

Chapman, W.M. 1963. Legal Problems in Harvesting Minerals of the Deep Sea-Bed. Van Camp Foundation.

Charles River Associates. 1982. Analys is of Major Policy Issues Raised by the Commercial Development of Ocean Manganese Nodules. CRA Report No: 383. Prepared for the National Science Foundation. 
Charles River Associates. 1980. Energy Requirements for Metals Production: Comparison Between Ocean Nodules and Land-Based Resources. Contract report. Washington: Office of Ocean Minerals and Energy, NOAA, U.S. Department of Commerce.

Charles River Associates. 1979. Economic Feasibility of Mining Blake P1ateau Manganese Nodules. CRA Report No. 461. Reston, Va.: U.S. Geological Survey.

Charlier, R.H., 1983. "Water, Energy, and Nonliving Ocean Resources" Oceans Yearbook 4: 75-120. Chicago: University of Chicago Press.

Charlier, R.H. 1978. "Other Ocean Resources". Ocean Yearbook 1. Chicago: University of Chicago Press.

Chaziteodo, G. and A. Wienen. 1974. "Extraction and Haulage of Manganese Nodules from the Deep Sea." Meerestechnik 5(2): 37-43.

Christy, F.T., Jr. 1975. "Property Rights in the World Ocean." Natural Resources Journa1 15: 695-712.

Christy, F.T., Jr. 1971. "Economic Problems and Prospects for Exploitation of the Resources of the Sea-Bed and its Subsoil." In Symposium on the Exploration and Exploitation of the Sea-Bed and its Subsoil. New York: U.S. and World Publications, Inc., Manhattan Publishing Company.

Christy, F.T., Jr. 1970. "Marigenous Minerals: Wealth, Regimes and Factors of Decision." Proc. Symposium on the International Regimes of the Sea-bed. Washington: Resources for the Future, pp. 113-153.

Christy, F.T., Jr. 1968. "Economic Criteria for Rules Governing Exploitation of Deep Sea Minerals." International Lawyer 2(2): 224-242.

Christy, F.T., Jr. 1968. "Alternative Regimes for the Marine Resources Underlying the High Seas." Natural Resources Lawyer 1(2): 63-77.

Christy, F.T., Jr. 1968. "Minerals of the Deep Sea." Proc. Third Annual Law of the Sea Institute, pp. 331-333.

Christy, F.T., Jr. and D.B. Brooks. 1966. "Shared Resources of the World Community." In Commission to Study the Organization of Peace.

Seventeenth Report. Dobbs Ferry, N.Y.: Oceana, pp. 135-165.

Christy, F.T., Jr. and J. Goodier. 1968. "Legal Aspects of the Exploitation of Offshore Mineral Deposits." Mining Engineering 20: 149-152.

Church, A.M. 1982. "Economic Rent, Economic Efficiency, and the Distribution of Natural Resource Tax Burdens: Copper and Coal." Natural Resources Journal 22: 559-595.

Circum-Pacific Council for Energy and Mineral Resources. 1984. Mineral Resources Map of the Circum-Pacific Region, Northeast Quadrant. Tulsa, Okla.: American Association of Petroleum Geologists. 
Cieslewicz, W.J. 1976. "Russia May Resort to Undersea Mining." Offshore 36(10): 167-181.

Clague, D., J. Bischoff and D.G. Howe11. 1984. "Nonfuel Mineral Resources of the Pacific Exclusive Economic Zone." Proc. Oceans '84. Washington: Marine Technology Society and Institute for Electrical and Electronics Engineers.

Clark, A.L. 1973. "Some Probable Impacts of Deep Ocean Mineral Resource Development." Proc. Ninth Annual Conference of the Marine Technology Society, pp. 253-258.

Clark, A.L. et a1. 1985. Resource Assessment: Cobalt-Rich Manganese Crust Potential. OCS Report MMS-85-0006. Long Beach, Calif.: U.S. Minerals Management Service.

Clark, A.L. and C.J. Johnson. 1986. "Cobalt-Rich Manganese Crust Potential of the U.S. Trust and Affiliated Territories." Proc. Offshore Technology Conference. Houston, pp. 111-118.

Clark, A.L., C.J. Johnson and P. Chinn. 1983. Assessment of Cobalt-Rich Manganese Crusts in the Hawaiian, Johnston and Palmyra Islands' Exclusive Economic Zones. Unpublished manuscript. East-West Resource Systems Institute. Honolulu.

Clark, J.P., N.J. Grant, and T.B. King. 1981. "The Market for Manganese Derived from Deepsea Nodules." Natural Resources Forum 5(3): 249-259.

Clark, J.P. and M.R. Neutra. 1981. Potential Economic and Environmental Consequences of Mining Deep Sea Manganese Nodules. Unpublished draft manuscript. Cambridge, Mass.: Department of Materials Science and Engineering, Massachusetts Institute of Technology.

Clarke, S.H. (ed.) 1984. Highlights in Marine Research. USGS Circular 938. Reston, Va.: U.S. Geological Survey.

Clement, G.K. et a1. 198 . Capital and Operating Cost Estimating System Manual for Mining and Beneficiation of Metallic and Nonmetallic Minerals Except Fossil Fuels in the United States and Canada. Bureau of Mines, U.S. Department of the Interior.

C1ifton, H.E. 1968. Gold Distribution in Surface Sediments on the Continental Shelf Off Southern Oregon: A Preliminary Report. USGS Circular 587. Washington: U.S. Geological Survey.

Coast and Geodetic Survey. 1966. Development Potential of U.S. Continental Shelves: A Report by the Battelle Memorial Institute. Washington: Government Printing Office.

Coffman, J.S. and C.M. Palencia. 1984. Manganese Availability--Market Economy Countries. IC 8978. Washington: Minerals Availability Program, U.S. Bureau of Mines. 
Coggins, G. and C. Wilkinson. 1987. Federal Public Land and Resources Law.

Cohen, H. 1982. "Mineral Development and the Coastal Areas." Energy Law and Policy 3: 113-168.

Cohen, L.I. 1983. "International Cooperation on Seabed Mining." In B.H. Oxman et a1. (eds.) Law of the Sea: U.S. Policy Dilemma. San Francisco, p. 101-109.

Coleman, R.G. 1977. Ophiolites: Ancient Oceanic Lithosphere? Minerals and Rocks Series, Vo1. 12. New York: Springer-Verlag (esp. pp. 125-130).

Co11is, D.S. 1974. "Britain's Involvement in the Finance of Offshore Operations." Offshore Services 7(8).

Collins, H.M. 1981. "Deep Seabed Hard Minerals Resources Act: Matrix for United States Deep Seabed Mining." Natural Resources Lawyer 13: 571-580.

Collins, H.M. 1979. "Mineral Exploitation of the Seabed: Problems, Progress, and Alternatives." Natural Resources Lawyer 12(4): 599-692.

Commeau, R.F. et a1. 1984. "Ferromanganese Crust Resources in the Pacific and Atlantic Oceans." Proc. Oceans '84. Washington: MTS and IEEE, pp. 421-430.

Commission on Marine Sciences, Engineering and Resources. 1969. Panel Report. Vo1. 3. Mineral Resources and Legal-Political Arrangements for Their Development. Washington: Government Printing office.

Committee for Cobalt Rich Crust Resources. 1986. The Second Report for Exploitation of Co-rich Manganese Crust. Japan Resources Association.

Committee on Deep Sea Mineral Resources. 1968. In W. Burke (rapporteur) Interim Report, American Branch of the International Law Association. New York.

Committee on Natural Resources and the Environment. 1975. Mineral Resources and the Environment. Washington: Commission on Natural Resources, National Research Council, National Academy of Sciences.

Conforti, B. 1979. "Notes on the Unilateral Exploitation of the Deep Seabed." Italian Yearbook of International Law 4: 3-19.

Congressional Research Service. 1985. Strategic Materials: Technologies to Reduce U.S. Import Vulnerability. Washington.

Congressional Research Service. 1978. Deep Seabed Minera1s: Resources, Diplomacy, and Strategic Interest. Committee Print, 95th Cong., 2d sess., House Committee on Internationa1 Relations.

Congressional Research Service. 1975. Ocean Manganese Nodules. Committee Print, 94th Cong., 1st sess., Senate, Committee on Interior and Insular Affairs. 
Congressional Research Service. 1974. The Economic Value of Ocean Resources to the United States. Study prepared by Robert R. Nathan Associates, Inc. Committee Print, 93rd Cong., 2d sess., Senate, Committee on Commerce, National Ocean Policy Study.

Conrad, R.F. and R.B. Hool. 1984. "Optimal Extraction with Grade Variation and Endogenous Reserves." Resources and Energy 6: 331-338.

Cooke, L.W. 1985. Estimates of Undiscovered, Economically Recoverable Oil and Gas Resources for the Outer Continental Shelf as of July 1984. OCS Report MMS-85-0012. Washington: U.S. Minera1s Management Service.

Cooke, R. 1984. "Meta1s in the Sea." Technology Review (Apri1): 55-60.

Costin, V.N. and G.A. Miroc. 1969. Underwater Exploitation of Minera1 Resources, U.S.S.R. Springfield, VA: Clearinghouse for Federal Scientific and Technical Information.

Cousineau, E. and P.R. Richardson. 1980. Gold: The World Industry and Canadian Corporate Strategy. Kingston, Ont.: Center for Resource Studies, Queen's University.

Crabbe, P.J. 1985. "Turgot's Brief on Mines and Quaries: An Ear1y Economic Ana1ysis of Land Tenure." Natura1 Resources Journa1 25: 267-273.

Craig, J.D., J.E. Andrews and M.A. Meylan. 1982. "Ferromanganese Deposits in the Hawaiian Archipelago." Marine Geology 45: 127-157.

Crauciuc, O.A.G. 1975. "L'Exploration et L'Exploitation Des Ressources Minérales Marines." Revue Roumaine des Sciences Sociales 19: 211-221.

Crawford, J.E. and J.W. Padan. 1965. "The Bureau of Mines' Expanding Role in Undersea Mining." Mining Engineering 17(3): 67-69.

Cressard, A. 1982. "Les Granulats Marins." Annales des Mines (November-December): 71-82.

Cronan, D.S. 1984. "Criteria for the Recognition of Areas of Potentially Economic Manganese Nodules and Encrustations in the CCOP/SOPAC Region of the Central and Southwestern Tropical Pacific." South Pacific Marine Geologica1 Notes 3(1): January.

Cronan, D.S. 1980. Underwater Minerals. Ocean Science, Resources and Technology: An International Series. London: Academic Press.

Cronan, D.S. 1977. "Deepsea Nodules: Distribution and Geochemistry." In G.P. Glasby (ed.). Marine Manganese Deposits. Amsterdam: E1sevier.

Cruickshank, M.J. 1982. "Options for Mining on the Blake Plateau." Oceans '82. Preprint.

Cruickshank, M.J. 1982. "Recent Studies on Marine Mineral Resources." Proc. Oceanography International. Preprint. 
Cruickshank, M.J. 1982. "The Case for Accelerated Ocean Mining." Ocean Industry (March): 28.

Cruickshank, M.J. 1979. "Deep Seabed Mining and Developing Countries-Consideration of Distributional Factors." Marine Technology Society Journa1 13(2): 5-9.

Cruickshank, M.J. 1974. "Mineral Resources Potential of Continental Margins." In Burk, C.A. and C.L. Drake (eds.) The Geology of Continenta1 Margins. New York: Springer-Verlag, pp. 965-1000.

Cruickshank, M.J. 1974. "Mode1 for Assessment of Benefit/Cost Ratios and Environmental Impacts of Marine Mining Operations." Proc. International Symposium on Minera1s and the Environment. London: Institution of Mining and Metallurgy.

Cruickshank, M. J. 1971. "Mining and Minera1 Recovery 1969." Proc. Topics in Ocean Engineering Seminar. Engineering Experiment Station Circular No. 41, pp. 83-93.

Cruickshank, M.J. 1970. "Economic Factors Involved in Non-Petroleum Drilling." Ocean Industry 5(11): 51-52.

Cruickshank, M.J. 1969. "Mining and Minera1 Recovery." In Undersea Technology Handbook, Directory, p. A45-A54.

Cruickshank, M.J. 1964. "Methods of Exploring the Ocean." Undersea Technology January: 29-32.

Cruickshank, M.J. 1964. "Methods of Mineral Recovery." Undersea Technology April: 29-31.

Cruickshank, M.J. and I.J. Collins. 1969. "Design of a Facility For Marine Mining Systems Research." Proc. Offshore Technology Conference. OTC 1034. Dallas, Texas.

Cruickshank, M.J. and H.D. Hess. 1975. "Marine Sand and Grave1 Mining." Oceanus 19(1): 32-44.

Cruickshank, M.J. and J.R. Moore. 1974. "Identification of Technologic Gaps in Exploration of Marine Ferromanganese Deposits." Government Reports Announcements 74(3): 28 .

Cruickshank, M.J., C.M. Romanowitz and M.P. Overa11. 1968. "Offshore Mining: Present and Future." Engineering and Mining Journa1 169: 84-91.

Cullen, D.J. 1984. "Comments on the Economic-Agronomic Potential and the Mining Feasibility of the Chatham Rise Phosphorite Deposits." Proc. 2nd International Seminar on Offshore Mineral Resources. Brest, France: March 19-23.

Cundiff, W.E. 1979. "Will Sudbury Survive the Impact of Ocean Mining?" Canadian Mining Journa1 100(5): 55-67. 
Curtis, C.E. and J.N. Barnes. 1982. "Deepsea Mining and the Environment." In $T$. Treves (ed.) Los fruttamento dei fondi marini internazionali, pp. 121-137.

Curtis, C.E. 1981. "Ocean Mining and the Law of the Sea." New Scientist 89: $736-738$.

Daily, A.F. 1969. "Off-the-Ice Placer Prospecting for Gold." Proc. Offshore Technology Conference 1, pp. 277-284.

Dames and Moore. 1980. "Environmental, Social and Economic Effects of Continued Reliance on Land Mining to Produce Metals Available from Manganese Nodules." Contract report. Washington: Office of Ocean Minera1s and Energy, NOAA, U.S. Department of Commerce. NTIS Report No. PB-81-180119.

Dames and Moore, EIC Corporation and B.V. Andrews. 1977. Description of Manganese Nodule Processing Activities for Environmental Studies. Volume I: Processing Systems Summary. Volume II: Transportation and Waste Disposal Systems. Volume III: Processing Systems Technical Analyses. Rockville, Md.: Office of Marine Minerals, NOAA, U.S. Department of Commerce.

Daridon, M. 1984. "Contraintes Liees a 1'Exploitation des Granulats Marins en France: Cas Particulier de Dieppe." Proc. 2nd International Seminar on Offshore Mineral Resources. Brest, France: GERMINAL, March 23.

Dasgupta, P.S., R.J. Gilbert and J.E. Stiglitz. 1982. "Invention and Innovation under Alternative Market Structures: The Case of Natural Resources." Review of Economic Studies 49: 567-582.

Dasgupta, P.S. and G.M. Hea1. 1979. Economic Theory and Exhaustible Resources. Cambridge, England: Nisbet.

Dasgupta, P.S. and G.M. Hea1. 1974. "The Optimal Depletion of Exhaustible Resources." Review of Economic Studies 41: 3-28.

Davenport, J.M. 1971. "Incentives for Ocean Mining: A Case Study of Sand and Gravel." Marine Technology Society Journal 5(4): 35-40.

Davis, J.D. and C. Archer. 1982. "Deep Ocean Mining: Who Wil1 Benefit from the 'Common Heritage'?" In F. Laursen (ed.) Toward a New International Marine Order. The Hague, pp. 151-176.

De Carlo, E.H., G.M. McMurtry and K.H. Kim. 1987. "Geochemistry of Ferro-manganese Crusts from the Hawaiian Archipelago--I. Northern Survey Areas." Deep-Sea Research 34(3): 441-467.

Deep Ocean Mining. 1982. Oceanus 25(3): Special Issue.

Deep-Sea Hot Springs and Cold Seeps. 1984. Oceanus 27(3): Special Issue. Defense Mapping Agency. 1981. Gazetteer of Undersea Features. Third Edition. 
Degens, E.T. and D.A. Ross (eds.) 1969. Hot Brines and Recent Heavy Meta1 Deposits in the Red Sea. New York: Springer-Verlag.

DeGroot, S. 1986. "Marine Sand and Gravel Extraction in the North Atlantic and Its Potential Environmental Impact, With Emphasis on the North Sea." Ocean Management 10: 21-36.

Dehais, J.A., P.L. Guyette and W.A. Wa1lace. 1981. "Onshore Pressures Make offshore Mining Viable." Rock Products (June): 72-76.

Dehais, J.A. and W.A. Wallace. 1980. "Economics of Offshore Mining of Fine Mineral Aggregate." Trans. Society of Mining Engineers of AIME 270: 1936-1940.

Delach, M. and B. Horn. 1972. Ferromanganese Deposits on the Ocean Floor. Washington: Office for the International Decade of the Ocean Exploration, National Science Foundation.

Denman, D.R. 1984. Markets Under the Sea? A Study of the Potential of Private Property Rights in the Seabed. Hobart Paperback No. 17. London: Institute of Economic Affairs.

Denman, D.R. 1981. "Minerals, Mining and Maritime Resource Management." Ocean Management 7: 25-40.

Dennis, W.H. 1967. "Metal Potential of the Sea." Metallurgia 76(457): 199-200.

Denton, D.K. 1985. Review of Existing, Developing, and Required Technology for Exploration, Delineation, and Mining of Seabed Massive Sulfide Deposits. Spokane, Wash.: Western Field Operations Center, U.S. Bureau of Mines.

Department of Economic and Social Affairs. 1970. Mineral Resources of the Sea. New York: United Nations.

Department of Engineering \& Public Policy. 1985. Seabed Mining of Cobalt-Rich Manganese Crusts in the Pacific United States Exclusive Economic Zone. Pittsburgh, Pa.: Carnegie-Mellon University.

Department of International Economic and Social Affairs. 1982. Sea-Bed Mineral Resource Development. ST/ESA/107/Add.1. New York: United Nations.

Department of International Economic and Social Affairs. 1980. Sea-Bed Mineral Resource Development: Recent Activities of the Internationa1 Consortia. ST/ESA/107. New York: United Nations.

Department of the Interior. 1968. Marine Resources Development, A National Opportunity. Washington: Office of the Secretary.

Department of the Interior, National Oceanic and Atmospheric Administration, and the Smithsonian Institution. 1985. Symp. Proc. The Exclusive Economic Zone: Exploring the New Ocean Frontier. Washington: NOAA. 
Department of Planning and Economic Development. 1981. The Feasibility and Potential Impact of Manganese Nodule Processing in the Puna and Kohala Districts of Hawaii. Honolulu: STate of Hawaii with NOAA, U.S. Department of Commerce.

Derkmann, K.J., R. Fellerer and H. Richter. 1981. "Ten Years of German Exploration Activities in the Field of Marine Raw Materials." Ocean Management $7: 1-8$.

Derry, D.R. 1980. World Atlas of Geology and Mineral Deposits. London: Mining Journal Books Ltd.

Deshmukh, S.D. and S.R. Pliska. 1980. "Optimal Consumption and Exploration of Nonrenewable Resources Under Uncertainty." Econometrica 48(1): 177-199.

Devarajan, S. and A. Fisher. 1982. "Exploration and Scarcity." Journal of Political Economy 90(6): 1279-1290.

DeYoung, J.H., D.M. Sutphin and W.F. Cannon. 1984. International Strategic Minerals Inventory Summary Report--Manganese. U.S. Geological Survey Circular 930-A. Alexandria, Va.: Department of the Interior.

Diebold, P. 1973. "The Richness of the Sea: Minera1s." Proc. Symposium on the Future of the Sea. The Hague: Den Helder, pp. 51-76.

Diethrich, M. (presiding). 1978. "Discussion Forum: Have Polymetallic Nodules an Economic Future?" Proc. 1st International Seminar on Offshore Minera1 Resources. Orléans, France: GERMINAL and BRGM, October 23-27.

Dietz, R.S. 1972. "Mineral Resources and Power." In Idy11, C.P. (ed.) Exploring the Ocean Wor1d: A History of Oceanography. New York: Thomas Y. Crowe11 Company, pp. 194-195.

Dillon, W.P. 1984. "Mineral Resources of the Atlantic Exclusive Economic Zone." Proc. Oceans '84. Washington: Marine Technology Society and Institute for Electrical and Electronics Engineers.

Dixon, C. 1979. Atlas of Economic Mineral Deposits. Chapman and Ha11.

Djala1, H. 1981. "Law of the Sea Conference: Other Alternatives for Seabed Mining." New York Law School Journal of International and Comparative Law 3: $39-49$.

Dobretsov, V. and V. Millers. 1976. "Main Problems of Exploration and Industrial Exploitation of Arctic Shelf Placers." Morskaia Geologiia I Geofizika 5: 97-103.

Documentation Associates. 1977. Deep Ocean Mining Environmental Study (DOMES) Literature Survey. Report No. PB279421/AS. Springfield, Va.: National Technica1 Information Service.

Dodds, D. and R.C. Bishop. 1983. "On the Role of Information in Minera1 Exploration." Land Economics 59(4): 411-19. 
Dombrovski, John. 1973. "Exploitation of Seabed Mineral Resources--Chaos or Legal Order?" Corne11 Law Review 58: 575-601.

DOMES Project Office. 1976. "Progress Report, Deep Ocean Mining Environmental Study Phase I." NOAA Technica1 Memo. ERL-MESA-15. Boulder, Colo.: NOAA, U.S. Department of Commerce.

Donges, J.B. (ed.) 1985. The Economics of Deep-Sea Mining. Berlin: Springer-Verlag.

Doumani, G.A. 1971. "Exploiting the Resources of the Seabed." In Report on Science, Technology and American Diplomacy: Exploiting the Resources of the Seabed. Washington: Government Printing Office, $159 \mathrm{p}$.

Dougherty, E.L. and J. Lohrenz. 1976. "Statistical Analyses of Bids for Federal offshore Leases." Journal of Petroleum Technology 28(November): 1377-1390.

Drechsler, H.D. 1973. "Exploitation of the Sea: A Preliminary Cost-Benefit Analysis of Nodule Mining and Processing." Maritime Studies and Management 1(1): 53-66.

Drechsler, H.D. 1966. "The Value of Subsea Mineral Resources." Proc. Law of the Sea Institute 1: 112-117.

Drew, L.J. and D.H. Root. 1982. "Statistical Estimate of Tomorrow's Offshore $0 i 1$ and Gas Fields." Ocean Industry (May): 54-58.

Drolet, J.P. 1979. "Deep seabed Mining--A Canadian Perspective in Relation to the Nickel Industry." CIM Bulletin 72 (801): 113-125.

Drury, O.P. (ed.) 1982. Materials Risk Management. Proc. of the Government/Industry Seminar. Washington: Office of Strategic Resources, Department of Commerce.

Duane, D.B. 1982. "Elements of a Proposed Five-Year Research Program on Polymetallic Sulfides." Marine Technology Society Journal 16: 87-91.

Duane, D.B. 1976. "Sedimentation and Ocean Engineering: Placer Mineral Resources." In D.J. Stanley and D.J.P. Swift (eds.) Marine Sediment Transport and Environmental Management. New York: John Wiley \& Sons, pp. 535-556.

Duane, D.B. 1968. "Sand Deposits on the Continenta1 She1f, A Present1y Exploitable Resource." Proc. 4th Annual Marine Technology Society Conference. Washington: pp. 289-97.

Duane, D.B. and J.W. Padan. 1984. "NOAA Activities in Marine Mining." Proc. Oceans '84. Washington: MTS and IEEE.

Duane, D.B. and W.L. Stubblefield. 1986. "Sand and Gravel Resources: U.S. Atlantic Continental She1f." In The Geology of North America. Vo1. I-2. 
Dubs, M.A. 1984. "The Case for Nodules and the Wealth of the Deep Sea." In C.E. Maw (ed.) What Law Now for the Seas. Washington, p. 43-47.

Dubs, M.A. 1983. "The Future of the Exploitation of the Resources of the Deep Seabed and Subsoil: Comment." Law and Contemporary Problems 46(2): 81-85.

Dubs, M.A. 1981. "Deep Seabed Mining: Where Do We Go from Here?" Interview conducted by J.C. Todd. Engineering \& Mining Journa1 182(9): 123-133.

Earney, F.C.F. 1986. "Seashells and Cement in Iceland." Marine Mining 5(3): 307-319.

Earney, F.C.F. 1980. Petroleum and Hard Minerals from the Sea. New York: John Wiley \& Sons.

Earney, F.C.F. 1975. "Ocean Space and Seabed Mining." Journal of Geography $74(9): 539-47$.

Eckert, R. 1974. "Exploitation of Deep Ocean Minerals: Regulatory Mechanisms and United States Policy." Journal of Law and Economics 17(1): 143-177.

Economic Associates, Inc. 1968. The Economic Potential of the Mineral and Botanical Resources of the U.S. Continental Shelf and Slope. Springfield, Va.: Clearinghouse for Federal Scientific and Technical Information.

Economic Commission for Asia and the Far East. 1973. Proc. Seminar on Petroleum Legislation with Particular Reference to offshore Operations. Mineral Resources Development Series No. 40. New York: United Nations.

Economic and Social Council. 1985. Economic and Technical Trends and Developments in Marine Affairs. Report of the Secretary General. E/1985/79. Section II.B. Marine Resource Development, Minera1 Resources. New York: United Nations, p. 11.

Edmiston, K. 1983. "The Status of Marine Mining." Ocean Industry 18(1): $4-50$.

Edwards, H.L. 1972. "Federal Hard Mineral Leasing Practices Under Existing Law." Rocky Mountain Minera1 Law Institute 17: 281-300.

Edwards, H.L. 1972. "The 1969 View of the 1872 Mineral Law: Current Proposals to Modernize or to Replace the General Mining Laws." Rocky Mountain Minera1 Law Institute 15: 139-161.

Eek, W.H.V. 1971. "Technology and Prospects for the Use of Areas and Mineral Resources of the Sea-Bed and its Subsoil." In Symposium on the Exploration and Exploitation of the Sea-Bed and its Subsoil. New York: U.S. and World Publications, Inc., Manhattan Publishing Company.

Eggert, R.G. 1987. Metallic Mineral Exploration: An Economic Analysis. Washington: Resources for the Future. 
Eggert, R.G. 1985. "Mineral Exploration in the USSR and the USA." Resources Policy (June): 128-140.

EIC Corporation and B.V. Andrews. 1977. Estimated Costs for Representative Manganese Nodules Waste Disposa1 Alternatives. Contract report. Rockville, Md.: Office of Marine Minerals, NOAA, U.S. Department of Commerce.

E1y, N. 1976. "Deep Seabed Minerals--Congress Stems to Rescue." Internationa1 Lawyer 10(3): 537-43.

E1y, N. 1974. Summary of Mining and Petroleum Laws of the Wor1d. IC 8610. Washington: U.S. Bureau of Mines.

E1y, N. 1971. "Draft United Nations Convention on the Internationa1 Seabed Area--American Bar Association Position." Natural Resources Lawyer 4: $60-72$.

E1y, N. 1970. "Policy Considerations in the Development of Mineral Laws." Natura1 Resources Lawyer 3: 281-297.

E1y, N. 1969. Lega1 Problems in Undersea Minera1 Development. Washington: Society of Mining Engineers.

E1y, N. 1969. "The Law Governing the Development of Undersea Minera1 Resources." Proc. Offshore Technology Conference. Houston: p. 19-42.

E1y, N. 1968. "The Fashioning of a Regime to Govern the Development of Undersea Mineral Resources." Presented at the Workshop on Law as Related to Ocean Development Problems. Washington: Marine Technology Society and George Washington University Nationa1 Law Center.

E1y, N. 1968. "American Policy Options in the Development of Undersea Minera1 Resources." International Lawyer 2(2): 215-223.

E1y, N. 1968. "A Case for the Administration of Mineral Resources Underlying the High Seas by National Interests." Natural Resources Lawyer 1(2): 78-84.

E1y, N. 1966. "The Laws Governing Exploitation of the Minera1s Beneath the Sea." Trans. Second Annual Conference of Marine Technology Society. Washington, pp. 373-378.

Ember, L.R. 1981. "Many Forces Shaping Strategic Minerals Policy." Chemical and Engineering News (May 11): 20-23.

Emery, K.0. 1981. "Geological Limits of the 'Continental Shelf"". Ocean Development and Internationa1 Law 10: 1-11.

Emery, K.0. 1968. "The Continental Shelf and Its Mineral Resources." Proc. Governors Conference on Oceanography. New York, p. 36-51. 
Emery, K.0. 1967. "Geological Aspects of Sea-Floor Sovereignty." Proc. First Annual Conference of the Law of the Sea Institute. Columbus: Ohio State University, pp. 139-159.

Emery, K.0. 1966. "Geological Methods for Locating Mineral Deposits in the Ocean Floor." Trans. Second Annual Conference of Marine Technology Society, Washington, p. 24-43.

Emery, K.0. and L.C. Noakes. 1968. "Economic P1acer Deposits of the Continental Shelf." Technical Bulletin, ECAFE 1: 95-111.

Emery, K.0. and L.C. Noakes. 1968. "Economic Placer Deposits of the Continental Shelf." Offshore 29(3): 91-105.

Emery, K.0. and B.J. Skinner. 1977. "Mineral Deposits of the Deep-Ocean F1oor". Marine Mining 1: 1-71.

Emery, K.0. and E. Uchupi. 1984. The Geology of the Atlantic Ocean. New York: Springer-Verlag.

Energy Information Administration. 1986. Persona1 communication. Washington: U.S. Department of Energy.

Energy Information Administration. 1986. Month1y Energy Review. Washington: U.S. Department of Energy (April).

Energy Information Administration. 1984. U.S. Crude 0il, Natural Gas, and Natural Gas Liquids Reserves. 1984 Annual Report. Washington: U.S. Department of Energy.

Energy, Mines and Resources Canada. 1971. Offshore Exploration: Information and Procedures. Ottawa: Resource Administration Division, EMR.

Energy Resources and Materials Production Subcommittee. 1979. Deep Seabed Mineral Resources Act. Joint Hearings. U.S. Senate, Energy and Natura1 Resources Committee and Commerce, Science and Transportation Committee, 96th Cong., 1st sess., Pub1ication No. 96-16.

Englebrecht-Wiggans, R. 1980. "Auctions and Bidding Models: A Survey." Management Science 6(2): 119-142.

Englebrecht-Wiggans, R., E.L. Dougherty and J. Lohrenz. 1986. "A Model for the Distribution of Bids on Federal Offshore Oil Leases." Management Science 32(9): 1087-1094.

Ensign, C.0., Jr. 1966. "Economic Barriers Delay Underseas Mining." Mining Engineering 18: 59-62.

Ensign, C.0., Jr. 1966. "The Economic Climate Needed to Make Underseas Mining Attractive to Industry." Trans. Second Annual Conference of Marine Technology Society, Washington, p. 65-82. 
Erickson, R.L. 1973. "Crustal Abundance of Elements, and Mineral Reserves and Resources." In Brobst, D.A. and W.P. Pratt (eds.) United States Mineral Resources. Geological Survey Professional Paper 820. Washington: U.S. Geological Survey, pp. 21-25.

Estefan, S.F. 1982. "Exploitation of the Mineral Wealth of the Red Sea." Speculations in Science and Technology 5(2): 151-156.

Eswaran, M. and T.R. Lewis. 1984. "U1timate Recovery of an Exhaustible Resource under Different Market Structures." Journal of Environmental Economics and Management 11: 55-69.

Etheridge, W.S. 1981. "Demand for Meta1s." Materials In Engineering 2 (March): 131-140.

Exon, N.F. 1982. "Manganese Nodules in the Kiribati Region, Equatorial Western Pacific." South Pacific Marine Geological Notes 2(6): May.

Exploration Survey Committee. 1986. "1985 Minera1 Exploration Statistics." Economic Geology 83: 257-263.

Fantel, R.J., D.E. Sullivan and G.R. Peterson. 1983. Phosphate Rock Availability--Domestic. IC 8937. Washington: Minerals Availability Progam Appraisa1, U.S. Bureau of Mines.

Fante1, R.J. et a1. 1984. Phosphate Rock Availability--World. IC 8989. Washington: Minerals Availability Progam Appraisal, U.S. Bureau of Mines.

Farr, P.J. 1982. "Meta1 Demand Forecasting and Deepsea Mining." Proc. Oceanology International. Brighton, England: March 2-5.

"Federal Repub1ic of Germany: Act of Interim Regulation of Deep Seabed Mining." 1980. International Legal Materials 20: 393-398.

Feitel'man, N. 1981. "The Economic Evaluation of Natura1 Resources." Problems of Economics 24(4): 39-56.

Fellerer, R. 1975. Bibliographie der Manganknollen--Literatur 1878-1975. Frankfurt: BMFT.

Filardi, L. 1984. "Canadian Perspectives on Seabed Mining: The Case of the Production Limitation Formula." Ocean Development and Internationa1 Law 13: 457-479.

Fine, D.I. 1983. "Geopolitical View of Mineral Resources." Proc. A National Program for the Assessment and Development of the Mineral Resources of the United States Exclusive Economic Zone. U.S. Geological Survey Circular 929.

Finlay, L.W. 1976. "United States Policy with Respect to High Seas Fisheries and Deep Seabed Minerals--Study in Contrasts." Natural Resources Lawyer $9(4): 629-43$. 
Fisher, D.E. and K. Bostrom. 1969. "Uranium Rich Sediments on the East Pacific Rise." Nature 224: 64-65.

Flanagan, J.P. 1984. "Manganese Nodules: A Huge Resource for the Future." Sea Technology (August): 18-21.

Flipse, J.E. 1983. "Deep Ocean Mining Economics." Sea Technology 24(1): 41-43.

F1ipse, J.E. 1982. An Economic Analysis of a Pioneer Deep Ocean Mining Venture. TAMU-SG-82-201. COE Report No. 262. College Station, Tex.: Texas A\&M University Sea Grant College Program.

Flipse, J.E. 1980. The Potential Cost of Deep Ocean Mining Environmental Regulation. Contract report. Washington: Office of Ocean Minerals and Energy, NOAA, U.S. Department of Commerce.

F1ipse, J.E. 1978. Ocean Minera1s. Unpublished Issue Paper for the National Advisory Commission on Oceans and Atmosphere Workshop on Federal Reorganization. Washington: September 16-17.

Flipse, J.E. 1970. "Ocean Mining Stimulated by Economic Forces." Undersea Technology 11(1): 45-46.

F1ipse, J.E. and R.J. Greenwald. 1970. "The Marine Operator's Role in the Rational Formulation of Principles of Law Governing Mining Activities in "Shared" Ocean Space." Proc. Sixth Annual Conference of the Marine Technology Society. Washington: Marine Technology Society.

Foders, F. and C. Kim. 1983. A Simulation Model for the World Manganese Market. Kiel Working Paper No. 170. Kie1, West Germany: Institut für Weltwirtschaft an der Universität Kiel.

Ford, G. and M. Gibbons. 1981. "Marine Resources Policy: An Interdisciplinary Approach." Journal of the Society for Underwater Technology $7: 1-5$.

Ford, G. and M. Gibbons. 1979. "Whose Nodules are They?" New Scientist 82: 631-633.

Foreign Relations Committee. 1979. Deep Seabed Hard Minera1s. Hearing. U.S. Senate, 96 th Cong., 1st sess.

Forest Service. 1977. Anatomy of a Mine from Prospect to Production. Washington: U.S. Department of Agriculture.

Forman, W.J., R.G. Dwyer and C.R. Cox. 1970. "Basic Mining Law Provides the Maximum Benefit for the General Public." Natural Resources Lawyer 3: 327-336.

Frazer, J.Z. 1977. "Manganese Nodule Reserves: An Updated Estimate." Marine Mining 1(1/2): 103-123. 
Frazer, J.Z. and M.B. Fisk. 1977. Nicke1 P1us Copper in Ferromanganese Nodules And Crusts from the Northeast Equatorial Pacific. La Jolla, Calif.: Scripps Institute of Oceanography.

Frey, H.R. (ed.) 1972. Resources of the World's Oceans. New York: New York University. Symposium proceedings.

Frosch, R.A. 1968. "Marine Mineral Resources--National Security and National Jurisdiction." In E. Keiffer (ed.) Symposium Proceedings of Mineral Resources of the World Ocean. Narragansett Marine Laboratory Occasional Publication No. 4, p. 96-101.

Fye, P.M. 1966. "The Economic Potential of the Oceans." Paper presented before the Third International Investment Symposium. Cambridge, Mass.: Harvard Business School.

Galtier, L. 1984. "Activities Minieres en Mer: Le Point au Plan Mondiale." Proc. Second International Seminar on Offshore Mineral Resources. Brest, France: GERMINAL.

Galtier, L. 1980. Nodules Polymetalliques. Orleans, France: GERMINAL.

Garnar, T.E. 1985. Minera1 Sand Products and Their Uses. Presented at SME Fal1 Meeting and Exhibit. Albuquerque, N.M.

Garnar, T.E. 1978. Heavy Mineral Mining in Florida. Presented at SME-AIME Fa11 Meeting. Preprint No. 78-H-351. Lake Buena Vista, Fla.

Garnaut, R. and A.C. Ross. 1975. "Uncertainty, Risk Aversion, and the Taxing of Natura1 Resource Projects". The Economic Journa1 85(June): 272-287.

Gaske11, T. 1965. "Minerals Under the Sea." New Scientist 26(442): 384-386.

Gaskins, D.W., Jr. and T. Tiesberg. 1976. "An Economic Analysis of Pre-Sale Esploration in Oil and Gas Lease Sales." In R.T. Masson and P.D. Qua11s (eds.) Essays in Honor of Joe S. Bain. Cambridge, Mass.: Ballinger Pub1ishing Co., pp. 241-258.

Gauss, G.A. et a1. 1983. "Geophysica1 and Sea Bed Sampling Surveys for Constructional Sand in the Nuku'alofa Lagoon, Tongatapu, Kingdom of Tonga." South Pacific Marine Geological Notes 2(10): February.

Geddes, R.A. 1982. "The Future of United States Deep Seabed Mining: Stil1 in the Hands of Congress." San Diego Law Review 19: 613-630.

Genera1 Accounting Office. 1985. Early Assessment of Interior's Area-Wide Program for Leasing offshore Lands. RCED-85-66. Washington.

General Accounting office. 1984. Implementation of the National Minerals and Materials Policy Needs Better Coordination and Focus. RCED-84-63. Washington. 
Genera1 Accounting Office. 1983. Congress Should Extend Mandate to Experiment with Alternative Bidding Systems in Leasing Offshore Lands. RCED-83-139. Washington.

General Accounting Office. 1983. Uncertainties Surround Future of U.S. Ocean Mining. NSIAD-83-41. Washington.

General Accounting Office. 1982. Interior Should Continue Use of Higher Roya1ty Rates for Offshore 0i1 and Gas Leases. RCED-83-30. Washington.

General Accounting Office. 1982. Actions Needed to Promote a Stable Supply of Strategic and Critical Minerals and Materials. EMD-82-69. Washington.

General Accounting office. 1982. Impediments to U.S. Involvement in Deep Ocean Mining Can be Overcome. EMD-82-31. Washington.

General Accounting Office. 1982. Status Report on Executive Branch Implementation of the "National Materials and Minerals Policy, Research and Development Act of 1980." EMD-82-27. Washington.

Genera1 Accounting Office. 1982. Review of Selected Aspects of Strategic and Critical Materials Stockpile Management. GAO/PLRD-82-85. Washington.

Geologica1 Survey. 1983. Symposium Proc. A National Program for the Assessment and Development of Marine Resources of the United States Exclusive Economic Zone. USGS Circular 929. Alexandria: U.S. Department of the Interior.

Geologica1 Survey. 1979. Program Feasibility Document: OCS Hard Minerals Leasing. Reston, Va.

Georghiou L., G. Ford and H. Cameron. 1982. "The Manganese Nodule Bonanza." Futures 14(6): 554-555.

Georghiou, L. and G. Ford. 1981. "Arab Silver from the Red Sea Mud." New Scientist (February 19): 470-472.

Gilley, O.W., G.V. Karels and R.P. Leone. 1986. "Uncertainty, Experience and the 'Winner's Curse' in OCS Lease Bidding." Management Science 32(6): $673-682$.

Gi11is, M. et a1. (eds.). 1980. Tax and Investment Polices for Hard Minerals. Cambridge, Mass.: Ballinger.

Giresse, P. et a1. 1984. "Les Phosphates au Large du Congo et du Gabon: Nature Geochimique et Conditions Mecaniques d'Accumulation." Proc. Second International Seminar on Offshore Mineral Resources. Brest, France: GERMINAL.

Glasby, G.P. 1986. "Near-shore Minera1 Deposits in the SW Pacific." In D.S. Cronan (ed.) Sedimentation and Mineral Deposits in the Southwestern Pacific Ocean. New York: Academic Press. 
Glasby, G.P. 1982. "Manganese Nodules from the South Pacific: An Evaluation." Marine Mining 3(3/4): 231-270.

Glasby, G.P. 1982. "Marine Minerals Around New Zealand." Alpha 20. Wellington, N.Z.: Science Information Division, Department of Scientific and Industrial Research

Glasby, G.P. 1979. "Minerals from the Sea." Endeavor (New Series) 3(2): $82-85$.

Glasby, G.P. (ed.) 1977. Marine Manganese Deposits. Elsevier Oceanography Series, 15. New York: Elsevier Scientific Publishing Company.

Glasby, G.P. 1975. Marine Mining in New Zealand: Prospects for Development." New Zealand Scientific Review 32: 53-56.

Glasby, G.P. 1975. Manganese Nodules and the U.N." New Zealand Scientific Review 32: 56-60.

Glasby, G.P. 1972. "The Mineralogy of Manganese Nodules from a Range of Marine Environments." Marine Geology 13: 57-72.

Glasby, G.P. and G.L. Hubred. 1976. Comprehensive Bibliography of Marine Manganese Nodules. New Zealand Oceanographic Institute Memoir 71. We11ington.

Glasby, G.P. and P. Lawrence. 1980. "Manganese Deposits in the South Pacific Ocean: Relation to Sediment Type." N.Z. Oceanogr. Inst. Chart.

Miscellaneous Series 40. Wellington, N.Z.: New Zealand Oceanographic Institute, Department of Scientific and Industrial Research.

Glassner, M.I. (ed.) 1983. Global Resources: Challenges of Interdependence New York: Praeger for the Foreign Policy Association.

Goeller, H.E. and A. Zucker. 1984. "Infinite Resources: The Ultimate Strategy." Science 223: 456-462.

Goldie, L.F.E. 1985. "Title and Use (Usufruct)--An Ancient Distinction Too oft Forgot." American Journal of International Law 79: 689-714.

Goldie, L.F.E. 1981. "A Selection of Books Reflecting Perspectives in the Seabed Mining Debate: Part I." International Lawyer 15: 293-337.

Goldie, L.F.E. 1981. "A Selection of Books Reflecting Perspectives in the Seabed Mining Debate: Part II." International Lawyer 15: 445-498.

Goldie, L.F.E. 1973. "A General International Law Doctrine for Seabed Regimes." Internationa1 Lawyer 7: 796-824.

Goldie, L.F.E. 1972. "Pollution and Liability Problems Connected with Deep-Sea Mining." Natural Resources Journal 12(2): 172-81. 
Goldman, H.B. 1969. "Sa1t, Sand and She1ls - Mineral Resources of San Francisco Bay." Special Report No. 97, California Division of Mines and Geology, pp. 33-40.

Goldstein, W. 1982. "Western Concerns Over Seabed Mining." Resources Policy $8(2): 82-83$.

Goodier, J.L. 1972. U.S. Federal and Seacoastal State Offshore Mining Laws. Washington: Nautilus Press.

Goodier, J.L. and A.J. Nalwalk. 1969. "Marine Mineral Identification Survey of Coastal Connecticut." Proc. Offshore Technology Conference 1, pp. 265-276.

Goodier, J.L. and S. Soehle. 1971. "Protecting the Environment During Marine Mining Operations." Oceanology International (November): 25-27.

Goralczyk, W. 1983. "The International Sea-Bed Authority." Polish Yearbook of Internationa1 Law 12: 77-93.

Gordon, R.L. 1973. "Ocean Resources and World Minera1 Supplies." Annalog d'Etudes Internationales 4: 109-125.

Gorham, M. 1978. "Dividing Up the Minerals of the Deep Seabed." Federal Reserve Bank of San Francisco Economic Review Winter: 7-19.

Gorham, M. 1977. "Ocean Mining in the Pacific Basin: Stimulus Response." Proc. Ninth Pacific Trade and Development Conference: Mineral Resources in the Pacific Area. San Francisco: Federal Reserve Bank.

Govett, G.S.J. and M.A. Govett. 1976. World Mineral Supplies. E1sevier Scientific Publishing Co.

Gray, L.C. 1914. "Rent Under the Assumption of Exhaustibility." Quarterly Journal of Economics 28: 66-89.

Green, D. 1980. "Ocean Mining--Bonanza, Superbonanza or Broke--Deep Ocean Mining--Opportunities for the U.K." Marine Policy 4(3): 257-259.

Grigg, R.W. 1984. "Economics and Future Development of the Precious Cora1 Fishery in the Pacific." In C. Gopalakrishnan (ed.) The Emerging Marine Economy of the Pacific. Boston: Ann Arbor Science, Butterworth Publishers.

Grolin, J. 1982. "The Deep Seabed: A North-South Perspective." In F. Laursen (ed.) Toward a New Internationa1 Marine Order, p. 119-149.

Grosz, A.E. 1987. Presentation at Georgia Task Force Meeting. Atlanta, Ga.: January 21.

Grosz, A.E. and E.C. Escowitz. 1983. "Economic Heavy Minerals of the U.S. Atlantic Continental Shelf." In W.F. Tanner (ed.) Sixth Symposium on Coasta1 Sedimentology. Tallahassee, Fla.: Florida State University, Pp. 231-242. 
Grosz, A.E., J.C. Hathaway and E.C. Escowitz. 1986. "Placer Deposits of Heavy Minerals in Atlantic Continental Shelf Sediments." Proc. Offshore Technology Conference. Houston, May 5-8.

Grote, P.B. and W.A. Coleman. 1978. A Preliminary Study of the Consequences of Deep Ocean Mining Technology Transfer. BUMINES-OFR-124-79. Washington: U.S. Bureau of Mines.

Grote, P.B., W.A. Coleman and G.M. Guard. 1980. Alternatives for Technology Transfer to the Enterprise. Science Applications, Inc., LaJolla, CA. Prepared for Bureau of Mines, Washington, DC.

Groupe d'Etude et de Recherche de Minéralisations Au Large. 1984. Second International Seminar on the Offshore Mineral Resources. Offshore Prospecting and Mining Problems: Current Status and Future Developments. Orleans, France.

Groupe d'Etude et de Recherche de Minéralisations Au Large. 1983. Panorama des Activités d'Exploration et d'Exploitation en 1982: Resources Minerales Sous-Marines. Orleans, France.

Groupe d'Etude et de Recherche de Minéralisations Au Large. 1982. Flash d'Information. Continuing Series. Orleans, France.

Guilcher, A. 1971. "Location and Evaluation of the Mineral Resources of the Sea-Bed and Its Subsoil." Symposium on the Exploration and Exploitation of the Sea-Bed and Its Subsoil. New York: Manhattan Publishing Company.

Guillen, 0. 1966. "Variacion De Fosfatos En La Region Maritima Del Callao Como Medida De La Produccion Primaria." Seminario Latino-Americano Sobre E1 Océano Pacifico Oriental. Lima: Universidad Nacional Mayor de San Marcos, pp. 73-76.

Gulley, D.A. 1982. "Severance Taxes and Market Failure." Natura1 Resources Journal 22: 598-617.

Gupta, P. 1981. An Econometric Mode1 of the World Coba1t Industry. Kie1 Working Paper No. 129. Kiel, West Germany: Institut für Weltwirtschaft.

Haggin, J. 1985. "Marine Mining to Improve Its Organization, Direction, Financing." Chemical \& Engineering News 63(46): 63-67.

Hahlbrock, U. 1979. "Mining Metalliferous Muds in the Red Sea." Ocean Industry (May): 45-48.

Ha1bach, P. 1984. "Deep-Sea Metallic Deposits." Ocean Management 9: 35-60.

Halbach, P. and R. Fellerer. 1980. "The Metallic Minerals of the Pacific Seafloor." Geojournal 4(5): 407-422.

Halbach, P., U. Hebisch and C. Scherhag. 1981. "Geochemical Variations of Ferromanganese Nodules and Crusts from Different Provinces of the Pacific Ocean and their Genetic Contro1." Chemica1 Geology 34: 3-17. 
Halbach, P. and F.T. Manheim. 1984. "Potential of Cobalt and Other Metals in Ferromanganese Crusts on Seamounts of the Central Pacific Basin." Marine Mining 4(4): 319-336.

Halbach, P., F.T. Manheim and P. Otten. 1982. "Co-Rich Ferromanganese Deposits in the Marginal Seamount Regions of the Central Pacific Basin--Results of the Midpac '81." Erzmetal1 35(9): 447-453.

Hale, P.B. 1984. Reappraisal of Offshore Non-Fue1 Mineral Development Potential. Ottawa: Canada $0 i 1$ and Gas Lands Administration.

Hale, P.B. and P. McLaren. 1984. "A Preliminary Assessment of Unconsolidated Mineral Resources in the Canadian Offshore." CIM Bulletin 1-11.

Hammond, A.L. 1974. "Manganese Nodules (I): Mineral Resources of the Deep Seabed." Science 183(4125): 502-503.

Hammond, A.L. 1974. "Manganese Nodules (II): Prospects for Deep Sea Mining." Science 183(4125): 644-646.

Hanemann, W.M. 1980. "Measuring the Worth of Natural Resource Facilities: Comment." Land Economics 56(4): 482-486.

Hansen, C.J. 1967. "Why a Location System for Hard Minera1s?" Rocky Mountain Minera1 Law Institute 13: 1-24.

Hardy, M. 1985. The Law of the Sea and the Prospects for Deep Seabed Mining. Unpublished Manuscript. 26th Annual Meeting of the International Studies Association. Washington: March 9.

Hardy, M. 1977. "Implications of Alternative Solutions for Regulating Exploitation of Seabed Minerals." International Organization 31(2): 313-42.

Harland W.B. et al. 1982. A Geologic Time Scale. Cambridge Earth Science Series, Cambridge, England: Cambridge University Press.

Harris, D.P. 1984. Mineral Resources Appraisa1. Minera1 Endowment, Resources, and Potential Supply: Concepts, Methods, and Cases. Oxford: Clarendon Press.

Harris, D.P. 1975. "Geostatistics in the Appraisal of Metal Resources." In W.A. Voge1y (ed.) Minera1 Materials Modeling: A State-of-the-Art Review. Baltimore: Johns Hopkins University Press for Resources for the Future.

Harris, D.P. and B.J. Skinner. 1982. "The Assessment of Long-Term Supplies of Minerals." In V.K. Smith and J.V. Krutilla (eds.) Explorations in Natural Resource Economics. Baltimore: Johns Hopkins University Press for Resources for the Future.

Harris, R.W. 1976. "The Law of Millsites: History and Application." Natura1 Resources Lawyer 9(1): 103-115. 
Harris, W.M., A.L. Lane and B.E. McFarlane. 1971. Outer Continental She1f: 0il, Gas, Sulfur and Sa1t, Leasing, Drilling, Production, Income and Related Statistics, 1953 Through 1969. Washington: U.S. Geological Survey. 63 p.

Harvey, W.W. 1987. Contractor Report on Mineral Processing. Arlington, Mass.: Arlington Technical Services.

Haspe1, A.E. and D.J. Bieniewicz. 1984. Are We Asking Too Much From Competition? Some Cases from Federal Mineral Leasing. Unpublished manuscript. Washington: Office of Policy Analysis, U.S. Department of the Interior.

Hatem, M.B. (ed.) 1983. Marine Polymetallic Sulfides: A National Overview and Future Needs. Workshop Proceedings. January 19-20. College Park, Md.: University of Maryland Sea Grant College and Office of Ocean Minerals and Energy, NOAA.

Hauser, W. 1983. The Legal Regime for Deep Seabed Mining Under the Law of the Sea Convention. The Netherlands: A. Metzner Kluwer.

Hauser, W. 1978. "An Internationa1 Fisca1 Regime for Deep Seabed Mining: Comparisons to Land-Based Mining". Harvard International Law Journal, 19(3): 759-812.

Hauser, W. 19 . "International Deep Seabed Mining: Institutional and Fisca1 Framework". Mining Ventures in Developing Countries.

Hawaii Department of Planning and Economic Development and Minerals Management Service. 1987. See: MMS (1987).

Hawaii Department of Planning and Economic Development. 1981. The Feasibility and Potential Impact of Manganese Nodule Processing in the Puna and Kohala Areas of Hawaii. Contract report. Rockville, Md.: Office of Marine Minerals, NOAA, U.S. Department of Commerce.

Haynes, B.W. et a1. 1983. Methods for Characterizing Manganese Nodules and Processing Wastes. IC 8953. Washington: U.S. Bureau of Mines.

Haynes, B.W. and S.L. Law. 1982. Predicted Characteristics of Waste Materials From the Processing of Manganese Nodules. IC 8904. Washington: U.S. Bureau of Mines.

Haynes, B.W., S.L. Law and D.C. Barron. 1982. Mineralogical and Elemental Description of Pacific Manganese Nodules. IC 8906. Washington: U.S. Bureau of Mines.

Haynes, B.W., S.L. Law and R. Maeda. 1983. Updated Process Flowsheets for Manganese Nodule Processing. IC 8924. Washington: U.S. Bureau of Mines.

Hazilla, M. and R.J. Kopp. 1984. "Assessing U.S. Vulnerability to Raw Material Supply Disruptions: An Application to Nonfuel Minerals." Southern Economic Journa1 51(2): 341-355. 
Hedberg, H.D. 1976. "Ocean Boundaries and Petroleum Resources." Science $191(4231)$ : 1009-1018.

Hedberg, H.D. 1971. "Legal Aspects of Seabed Petroleum and Minera1 Resource Development--The Draft United Nations Convention on the International Seabed Area and the United States Working Paper Submitted to the United Nations Seabed Committee: A Symposium. Opening Remarks." Natura1 Resources Lawyer 4: 681-682.

Hein, J.R., F.T. Manheim and W.C. Schwab. 1986. "Cobalt-Rich Ferromanganese Crusts from the Central Pacific." Proc. Offshore Technology Coonference. Houston, pp. 119-123.

Henderson, F.J. 1982. "British Deep Sea Mining Legislation." New Law Journal 132: 627-629.

Henkin, L. 1973. "The Changing Law of the Sea-Mining." Inter-University Program of Research on Ferromanganese Deposits of the Ocean Floor. Phase 1 Report, pp. 337-351.

Henkin, L. 1973. "The Changing Law of Sea-Mining." Annales d'Etudes Internationales 4: 281-305.

Henkin, L. 1969. "International Law and 'The Interests': The Law of the Seabed." American Journal of International Law 63: 504-510.

Henkin, L. 1968. Law for the Sea's Mineral Resources. ISHA Monograph No. 1. New York: Institute for the Study of Science in Human Affairs, Columbia University.

Herbich, J.B. 1975. Coasta1 and Deep Ocean Dredging. Houston, Texas: Gulf Publishing Company.

Herbich, J.B. 1970. "Methods for Deep-Ocean Mineral Recovery." In Conference Proceedings of Civil Engineering in the Oceans. II, pp. 297-313.

Herbich, J.B. 1969. "How the Deep Ocean Floor Can Be Mined." Ocean Industry 4(1): 48-51.

Herbich, J.B. 1968. "Deep Ocean Minera1 Recovery." Proc. World Dredging Conference, pp. 723-733.

Herfindah1, O.C. 1967. "Depletion and Economic Theory." In M. Gaffney (ed.) Extractive Resources and Taxation. Madison: University of Wisconsin Press.

Herfindah1, O.C. 1966. "Some Problems in the Exploitation of Manganese Nodules." Proc. First Annual Law of the Sea Institute, pp. 28-39.

Hering, N. 1973. "New Knowledge on Prospecting and Exploration of Ore Nodules Deposits." Meerestechnik 4(1): 1-11.

Hess, H.D. 1972. "Sand and Gravel Dredging Reaches Major Proportions." Wor1d Dredging and Marine Construction 8(6): 15-18. 
Hess, H.D. 1971. Marine Sand and Grave1 Mining Industry of the United Kingdom. NOAA Technical Report ERL 213-MMTC 1.

Heywood, D. 1982. "Deep Seabed Mining: Alternative Schemes for Protecting Developing Countries from Adverse Impacts." Georgia Journal of International and Comparative Law 12: 173-192.

Hibbard, B.H. 1924. A History of the Public Land Policies. New York: The MacMillan Company.

Hibbard, W.R. 1967. "Strategic Location is Key Factor in Marine Mineral Recovery." Undersea Technology 8(1): 47-49.

Hibbard, W.R. 1968. "Undersea Mining." Oceanology International 3(4): 46.

Hibbard, W.R. 1966. "The Government's Program for Encouraging the Development of a Marine Mining Industry." Trans. Second Annual Conference of Marine Technology Society. Washington, pp. 197-203.

Hidalgo, I.0. 1972. "Mini-Dredge (Iron Sand Mining) in the Philippines." World Dredging and Marine Construction 8(4): 13-15.

Hi11, P.A. and A. Parker. 1970. "Tin and Zirconium in the Sediments Around the British Isles: A Preliminary Reconnaissance." Economic Geology 65: 409-416.

Hillman, C.T. 1983. Manganese Nodule Resources of Three Areas in the Northeast Pacific Ocean: Proposed Mining-Beneficication. IC-8933. Washington: U.S. Bureau of Mines.

Hillman, C.T. and B.B. Gosling. 1985. Mining Deep Ocean Manganese Nodules. Bureau of Mines Information Circular 9015.

Hirobe, K. 1981. "Mineral Resources of the Sea and Delimitation." Fifth International Ocean Symposium: The Frontier of the Seas: The Problems of Delimitation. Tokyo: pp. 65-67.

Hirshleifer, J. and J.G. Riley. 1979. "The Analytics of Uncertainty and Information--An Expository Survey." Journal of Economic Literature 17: 1375-1421.

Hirunruk, V. and Netayaraksa, P. 1984. General Survey of Marine Resource Sector in Thailand. Unpublished manuscript. Workshop on Marine Resource Economics: Southeast Asian Seas in Transition. Honolulu: East-West Center, April 24-28.

Hoagland, P. 1986. "Seabed Mining Patent Activity: Some First Steps Toward An Understanding of Strategic Behavior." Journal of Resource Management and Technology 14(3): 211-222.

Hoagland, P. 1985. Patent Activity in the Seabed Mining Industry. WHOI-85-20. Woods Hole, Mass.: Woods Hole Oceanographic Institution. 
Hoard, K.A. 1982. The Role of the Federal Government in the Amelioration of the Risks Encountered in Deep Seabed Mining. Master's Thesis. Cambridge, Mass.: Department of Ocean Engineering, MIT.

Hocott, C.R. and P.E. Purser. 1983. "Energy and the Oceans." Proc. Oceans 184. San Francisco: MTS, OES, IEEE.

Hodges, C.A., D.P. Cox and D.A. Singer. 1983. International Minerals Resource Assessment Project. OFR 83-313. Denver, Colo. U.S. Geological Survey.

Holser, A.F. et a1. 1984. "United States Government Initiatives in the Assessment and Development of the Mineral Resources of the Exclusive Economic Zone of the United States." Proc. 2nd International Seminar on offshore Mineral Resources. Brest, France.

Holser, A.F., R.W. Rowland and M.R. Goud. 1981. A Compilation of Subsea Energy and Mineral Resources of the United States Including Its Possessions and Trust Territory of the Pacific Islands. MF-1360. Arlington, Va.: U.S. Geological Survey.

Horn, D.R., et a1. 1972. "Worldwide Distribution of Manganese Nodules." Ocean Industry 7: 26-29.

Horton, E. 1968. "A Discussion of Offshore Mineral Exploration Programs." Natura1 Resources Lawyer 1(3): 115-118.

Hosking, K.F.G. 1971. "The Offshore Tin Deposits of Southeast Asia." CCOP Technical Bulletin 5: 112-129.

Hotelling, H. 1931. "The Economics of Exhaustible Resources." Journal of Political Economy 39: 137-175.

Huggard, J.P. 1974. "The Deep Ocean and Its Non-Living Resources: A New Legal Rea1m." In S.W. Wurfel (ed.) Emerging Ocean Oil and Mining Law. Sea Grant Publication UNC-SG-74-02. Chape1 Hill: University of North Carolina School of Law, pp. 40-50.

Hughart, D. 1975. "'Informational Assymmetry, Bidding Strategies, and the Marketing of Offshore Petroleum Leases." Journal of Political Economy 83: 969-985.

Humphreys, D.L. 1972. "International Regime for the Exploration for and Exploitation of the Resources of the Deep Seabed--The United States Hard Minera1s Industry Position." Natural Resources Lawyer 5(4): 731-758.

Hunt, J.M. 1983. "Introduction: Offshore $0 i 1$ and Gas--Past, Present, and Future." Oceanus 26(3): 3-8.

Hutchinson, R.W. 1980. "Massive Base Metal Sulphide Deposits as Guides to Tectonic Evolution." In D.W. Strangway (ed.) The Continental Crust and Its Minera1 Deposits. Specia1 Paper 20. Waterloo, Ont.: Geological Association of Canada. 
Hyde, R. and J.R. Markusen. 1983. "Exploration Versus Extraction Costs as Determinants of Optimal Mineral-Rights Leases." The Economic Record (September): 224-234.

Ichiye, T. and M. Carnes. 1976. Mid-Ocean Aquaculture--Benefits of Deep Ocean Mining Operation. Report No. 284744/AS. Springfie1d, Va.: National Technical Information Service.

Inderbitzen, A.L., A.J. Carsola and D. Everhart. 1970. "The Submarine Phosphate Deposits off Southern California." Proc. Second Annual offshore Technology Conference, pp. 287-304.

Ingham, P.D. 1986. The Enterprise - Economic Viability of Deep Sea-Bed Mining of Polymetallic Nodules. Preparatory Commission for the International Sea-Bed Authority and for the International Tribunal for the Law of the Sea, Special Commission 2.

Interior and Insular Affairs Committee. 1953. Outer Continental Shelf. Washington: U.S. Senate, 83rd Cong., 1st sess., Hearings.

Interior and Insular Affairs Committee. 1953. Outer Continental Shelf Lands Act. Washington: U.S. Senate, 83rd Cong., 1st sess., Report No. 411.

Internationa1 Economic Policy and Trade Subcommittee and International Organizations Subcommittee. 1980. Deep Seabed Hard Mineral Resources Act. Washington: U.S. House, Foreign Affairs Committee, 96 th Cong., 1st sess, Hearings and Markup.

Jackson, J.G. 1976. "Deep Sea Ventures--Exclusive Mining Rights to Deep Seabed as a Freedom of Sea." Baylor Law Review 28(1): 170-186.

Jaenicke, G., E. Schanze and W. Hauser. 1981. A Joint Venture Agreement for Seabed Mining. Studies in Transnational Law of Natural Resources, Volume 5. Frankfurt/Main, West Germany: Alfred Metzner Verlag for the Institut für Ausländisches und Internationales Wirtschaftsrecht.

James, H.L. 1968. "Mineral Resources Potential of the Deep Oceans." In E. Keiffer (ed.) Symposium Proceedings of Mineral Resources of the World Ocean. Narragansett Marine Laboratory Occasional Publication No. 4, p. 39-44.

"Japan: Law on Interim Measures for Deep Seabed Mining." 1983. Internationa1 Legal Materials 22: 102-122.

Jenisch, U. 1983. "The International Seabed: Prospects for Mining in the 1980 's and the State of Negotiations." In C.H. Park (ed.) The Law of the Sea in the 1980s, pp. 170-183.

Jenisch, U. 1981. "Bridging the Gap for Seabed Mining: Preparatory Instruments for the New Law of the Sea Convention." San Diego Law Review 18: 409-413. 
Jenkins, R.L. and A.H. Lense. 1968. Marine Heavy Metals Project Offshore Nome, Alaska, July-August 1967. Technical Progress Report No. 4. Tiburon, Ore.: Heavy Metals Program, U.S. Bureau of Mines.

Johannas, A. 1983. "Activities of the Committee for Co-ordination of Joint Prospecting for Mineral Resources in Asian Offshore Areas (CCOP) 1966-1981." In D.M. Johnston et a1. (eds.) International Symposium on the New Law of the Sea in Southeast Asia. Halifax: Dalhousie University, pp. 90-104.

Johnson, M.H., K.W. Bell and J.J. Bennett. 1980. "Natural Resource Scarcity: Empirical Evidence and Public Policy". Journal of Environmental Economics \& Management 7: 256

Johnston, C.H. 1980. "Deep Seabed Mineral Resources Act." Natural Resources Journa1 1: 163-68.

Johnston, D.M. and N.G. Letalik (eds.). 1984. The Law of the Sea and Ocean Industry: New Opportunities and Restraints. Proc. Law of the Sea Institute Sixteenth Annual Conference. Honolulu: Law of the Sea Institute.

Johnston, J.L. 1978. "Economics of Minera1 Cartels and the Law of the Sea, IV." Marine Technology Society Journal 12(2): 35-37.

Johnston, J.L. 1977. "Seabed Minerals and the U.S. Economy: A Comment." Marine Technology Society Journa1 11(1): 37-38.

Jones, R.O., W.J. Mead and P.E. Sorenson. 1979. "The Outer Continental Shelf Lands Act Amendments of 1978." Natura1 Resources Journal 1: 885.

Jones, G.K. 1983. "The Development of Outer Continental Shelf Energy Resources." Pepperdine Law Review 11: 9.

Jones, G.K. 1982. "Onshore and Offshore Solutions to the Nonfuel Minerals Shortage." Brigham Young University Law Review: 617-694.

Jones, M.L. et a1. 1985. "Dive Data of Certain Submersibles, Hydrotherma1 and Other Sites." Biological Society of Washington Bulletin 6: 539-545.

Jones, W.B. 1983. "The International Sea-Bed Authority Without the U.S. Participation." Ocean Development and International Law 12: 151--171.

Joyner, C.C. 1975. International Law of the Sea and the Future of Deep Seabed Mining. Charlottesville: John Bassett Moore Society.

Joyner, C.C. 1975. "Towards a Legal Regime for the International Sea-Bed: The Soviet Union's Evolving Perspective." Virginia Journal of International Law 15(4): 871-901.

Juda, L. (ed.) 1983. The United States Without the Law of the Sea Treaty: Opportunities and Costs. Narragansett, R.I. 
Kalter, R.J. et a1. 1975. "The Economics of Outer Continental Shelf Leasing." American Journal of Agricultural Economics 57: 251-258.

Kamphausen, D. 1979. "Winning of Raw Materials by Deep Sea Mining and Structural Changes in the Terrestrial Mining in Developing Countries." Metal1 33(1): 88-91.

Kaplan, D.M. and R.E. Carver. 1976. "Distribution of Hornblende on the Atlantic Continental Shelf off Georgia, United States." Marine Geology $20(4): 335-343$.

Katz, H.R. and G.P. Glasby. 1979. "Mineral Resources of the New Zealand Offshore Region". South Pacific Marine Geological Notes 1(9): 95-110.

Katz, R.S. 1980. "A Method for Evaluating the Deep Seabed Mining Provisions of the Law of the Sea Treaty." Yale Journal of World Public Order 7: 114-130.

Katz, R.S. 1979. "Financial Arrangements for Seabed Mining Companies: An NIEO Case Study." Journal of World Trade Law 13(3): 209-22.

Kaufman, A.H. 1977. Significant Legal and Economic Issues in Legislating Political Risk Protection for Ocean Mining Investments. Rockville, Md.: Marine Minerals Office, NOAA, U.S. Department of Commerce.

Kaufman, A.H. 1970. "The Economics of Ocean Mining." Marine Technology Society Journa1 4(4): 58-65.

Kaufman, R. 1976. "Ocean Engineering Capabilities and Requirements for the offshore Mining Industry." In N.T. Monney (ed.) Ocean Resources Utilization. New York: American Society of Mechanical Engineers.

Kaufman, A. 1970. "A Survey of the Economics of Ocean Mining." Marine Technology Society Journa1 4(4): 58-65.

Keiffer, E. (ed.) 1968. Mineral Resources of the World Ocean. Proceedings of a Symposium held at the Nava1 War College, Newport, Rhode Island, July 11-12, 1968. Occasional publication no. 4. Kingston: University of Rhode Island.

Kesterke, D.G. 1984. "Ocean Minera1s: The Bureau of Mines Role in Mining and Resources Recovery." Proc. Oceans '84. Washington: MTS and IEEE.

Khachaturov, T. 1983. "Intensification of the Utilizaton of Material Resources." Problems in Economics 26: 3-13.

Kildow, J.T. (ed.) 1980. Deepsea Mining. Cambridge, Mass.: Massachusetts Institute of Technology Press.

Kilgore, C.C. and P.R. Thomas. 1984. Manganese Availability--Domestic. IC 8889. Washington: Minerals Availability Progam Appraisa1, U.S. Bureau of Mines. 
Kimba11, L. 1986. "Turning Points in the Future of Deep Seabed Mining." Ocean Development and International Law 17(4): 367-398.

Kimba11, L. 1985. "Status Report: Resolution of Overlapping Pioneer Mine Site Claims." In E.M. Borgese and N. Ginsburg (eds.) Ocean Yearbook 5. Chicago: University of Chicago Press, pp. 467-475.

Kimba11, L. 1980. "Implications of the Arrangements Made for Deep Sea Mining for Other Joint Exploitations." Columbia Journal of World Business 15: 52-61.

Kimbal1, L. 1979. "Mining Legislation." Environmental Policy and Law 5(1): 34.

Kimbe11, C.L., T.Q. Lyday and H.R. Newman. 1979. Mineral Industries of Australia, Canada and Oceania. Washington: U.S. Bureau of Mines.

Kindt, J.W. 1985. "Particulate Pollution and the Law of the Sea." Boston College Environmental Affairs Law Review 12: 273-311.

Kindt, J.W. 1984. "Deep Seabed Exploitation." UCLA Journal of Environmenta1 Law \& Policy 4: 1-55.

Kiss, A.C. 1979. "UNEP--Regulations for Drilling and Mining Activities in Sea." Environmenta1 Policy and Law 5(2): 79.

Kitch, E.W. 1977. "The Nature and Function of the Patent System." The Journal of Law and Economics: 265-290.

K1itgord, K.D. and J.S. Watkins. 1983. "Geologic Studies Related to Oil and Gas Development in the EEZ." Proc. Symposium: A National Program for the Assessment and Development of the Mineral Resources of the United States Exclusive Economic Zone. Reston, Va.

Knecht, R.W. 1982. "Deep Ocean Mining--Introduction." Oceanus 25(3): 3-11.

Knight, H.G. 1973. "The Deep Seabed Hard Mineral Resources Act--A Negative View." San Diego Law Review 10(3): 446-466.

Koegler, F.C. 1972. "Surface Concentrations of Deep-Sea Manganese Nodules." In Twenty-fourth Session of the International Geological Congress. Montrea1.

Koers, A.W. 1970. The Debate on the Legal Regime for the Exploration and Exploitation of Ocean Resources: A Bibliography for the First Decade, 1960-1970. Law of the Sea Institute Special Publication No. 1. Kingston: R.I.: University of Rhode Island.

Koga, M. "Developing a Manganese Nodule Policy for Japan." In R.L. Friedheim et a1. (eds.) Japan and the New Ocean Regime. Boulder, Co10.: Westview Press, pp. 227-275. 
Koh, T.T.B. 1985. "Deep Seabed Resources are the Common Heritage of Mankind." In J.M., Van Dyke (ed.) Consensus and Confrontation: The United States and the Law of the Sea Convention, pp. 228-232.

Kolodkin, A. 1985. "The Common Heritage of Mankind of the Seabed: The Notion and the Substance." In J.M. Van Dyke (ed.) Consensus and Confrontation: The United States and the Law of the Sea Convention, pp. 241-248.

Komar, P.D. and C. Wang. 1984. "Processes of Selective Grain Transport and the Formation of Placers on Beaches." Journal of Geology 92: 637-655.

Koomsup, P. 1983. Minerals and Energy in Thailand. Unpublished manuscript. ASEAN-Australia Joint Research Project: Study on Internationa1 Trade in Minerals, Energy and Processed Mineral Products. Bangkok: Thammasat University.

Kostin, V.N. and G.A. Nurok. 1969. Underwater Exploitation of Mineral Resources. Technical Translation No. JPRS 47700. Washington: U.S. Joint Publications Research Service, 8p.

Kronmiller, T.G. 1982. "Lega1 Regimes for Mining Hard Rock Marine Minera1s Within 200-Miles." Proc. Oceans '82. Washington: MTS and IEEE, pp. 1209-10.

Kronmiller, T.G. 1979. The Lawfulness of Deep Seabed Mining. Report No. PB-298458. Rockville, Md.: Marine Minerals Division, NOAA, U.S. Department of Commerce.

Krueger, R. 1969. "The State of International Law As Applied to Ocean Mining and an Examination of the Offshore Mining Laws of Selected Nations." In Offshore Technology Conference, p. 333-374.

Krueger, R.B. 1969. Underwater Exploitation of Mineral Resources, U.S.S.R. Springfield, Va: Government Clearing House.

Krueger, R.B. 1968. Public Land Law Review Commission Outer Continental Shelf Lands Study: Summary. Los Angeles: Nossaman, Waters, Scott, Krueger \& Riordan.

Krueger, R.B. 1967. "Mineral Development on the Continental Shelf and Beyond." Journal of the State Bar of California 42: 515-533.

Krueger, R.B. and L.H. Singer. 1979. "An Analysis of the Outer Continental Shelf Lands Act Amendments of 1978." Natura1 Resources Journal 19: 909-927.

Krutein, M.G. 1969. "Ocean Mining.." Proceedings of the U.S. Naval Institute 95(5): 135-140.

Kudrass, H.R. and U. Von Rad. 1984. "Geology and Economic Aspects of the Chatam Rise Phosphorite Deposits East of New Zealand: Results of R.V. Sonne Cruise 1981." Proc. Second International Seminar on Offshore Mineral Resources. Brest, France: March 19-23. 
Kulm, L.D. et al. 1968. "A Preliminary Investigation of the Heavy Mineral Suites of the Coastal Rivers and Beaches of Oregon and Northern California." The Ore Bin 30(9): 168-184.

Kulvanich, S. 1984. "Present and Future offshore Tin Prospecting and Mining in Thailand." Proc. Second International Seminar on Offshore Mineral Resources. Brest, France: March 19-23.

Kumar, C.K. 1982. "Commonwealth View of Deep-Sea Mining." Marine Policy $6(3): 239-241$.

Labys, W.C. 1980. Market Structure, Bargaining Power, and Resource Price Information. Cambridge, Mass.: D.C. Heath and Company.

Lahman, H.S. and J.B. Lassiter, III. 1972. The Evolution and Utilization of Marine Mineral Resources. MIT-SG-72-9. Cambridge, Mass.: Massachusetts Institute of Technology.

Lampietti, F.J. and L.F. Marcus. 1979. "Manganese Nodules on the Sea Floor: Are Economic Mining Operations Feasible?" Science 203(4380): 565.

LaMotte, C. 1970. "Deepsea Ventures Pilot Run is Successfu1." Ocean Industry 5: 7-14.

Landsberg, H.H., J.E. Tilton and R.B. Haas. 1982. "Nonfuel Minerals." In P.R. Portney and R.B. Haas (eds.) Current Issues in Natural Resource Policy. Baltimore: The Johns Hopkins University Press for Resources for the Future, pp. 74-116.

Lane, A.L. 1977. "U.S. Needs in Marine Minerals." Marine Technology Society Journal 2(1): 30-36.

Lane, C.M. et a1. 1986. Station Maps of the World Ocean-Ferromanganese-Crust Data Base. MF-1869. Woods Hole, Mass.: U.S. Geological Survey.

Lange, J., H. Bäcker, and L. Karbe. 1981. "Metalliferous Sediments in the Atlantis II Deep--Deposit and Environmental Investigations." I0

81-403/01. Proc. Interocean '81: 116-122.

Langeraar, W. 1969. "Thoughts on an International Regime and Administrative Agency for the Seabed and Ocean Floor Beyond the Limits of National Jurisdiction." Journal of Maritime Law and Commerce 1: 123-130.

Langevad, E.J. 1983. "Exploitation of the Mineral Resources of the Oceans as Affected by the Provisions of the Convention on the Law of the Sea." Natural Resources Forum 7: 227-238.

Langevad, E.J. 1981. "Production Policy for the Deep Sea Mineral Resources." Marine Policy 5: 264-267.

Langley, V.E. 1970. Middle East Offshore Minera1 Law. New York. 
LaQue, F.L. 1986. "Prospects for and from Deep Ocean Mining of Ferro-manganese Nodules." Hague Academy of International Law. Management of Society's Resources--The Law of the Sea.

LaQue, F.L. 1980. "Possible Contribution of Deep-Sea Mining to a New World Economic Order." Marine Technology Society Journal 1: 16-19.

LaQue, F.L. 1972. "Deep-Ocean Mining: Prospects and Anticipated ShortTerm Benefits." In E.M. Borgese (ed.) Pacem in Maribus. New York: Dodd, Mead, pp. 131-145.

LaQue, F.L. 1971. "Prospects For and From Deep Ocean Mining." Marine Technology Society Journal 5(2): 5-15.

Larsen, D.L. 1984. "Deep Seabed Mining: American and Indian Perspectives." Ocean Development and International Law 14: 193-200.

Larson, D.L. 1985. Deep Seabed Mining: A Definition of the Problem. Unpublished Manuscript. 26th Annual Meeting of the International Studies Association. Washington: March 9.

Lasserre, P. 1984. "Reserve and Land Prices with Exploration Under Uncertainty." Journal of Environmental Economics and Management 11: 191-201.

Lassiter, J.B., J.E. Soden and R.J. Powers. 1974. An Assay of the Marine Resources of Massachusetts Bay. MITSG 74-26. Cambridge, Mass.: MIT Sea Grant Program.

Laswe11, G. 1983. "Implied Covenants to Reasonably Deve1op: Should Hard-Mineral Applications Follow Oil and Gas Precedent?" Houston Law Review 20: 883-898.

Law and Contemporary Problems 46(2) (Spring 1983). Entire Issue.

Lay, S.H. 1985. "An Analysis of the Deep Seabed Mining Provisions of the Law of the Sea Convention." University of Dayton Law Review 10: 319-337.

Laylin, J.G. 1973. "The Legal Regime of the Deep Seabed Pending Multinational Agreement." Virginia Journal of Internationa1 Law 13: 319-330.

Laylin, John G. 1972. "Interim Practices and Policy for the Governing of Seabed Mining Beyond the Limits of National Jurisdiction." Proc. Seventh Annual Conference of the Law of the Sea Institute.

Lax, D.A. and J.K. Sebenius, 1981. "Insecure Contracts and Resource Development". Public Policy, 29(4): 417-436.

Lazarev, M.I. 1975. "Scientific--Technologica1 Progress and the Search for Lega1 Regulation of Possible Seabed Uses." Ocean Development and International Law 3: 75-86. 
Lee. T.K. 1982. "Resource Information Policy and Federal Resource Leasing." Be11 Journal of Economics 13(2): 561-568.

Lee, W.W.L. 1979. Decisions in Marine Mining. Lexington, Mass.: Ballinger.

Lee, W.W.L. and M.S. Baram. 1975. "Coasta1 Resource Management in the United States: The Case of Submarine Sand and Grave1 Extraction." Proc. Sixth World Dredging Conference. San Pedro, Calif.: Symcom.

LeGouellec, P., G. Herrouin and C. Charles. 1984. "Bilan Global des Activites Francaises dans 1'Exploitation des Nodules: Objectifs du Programme GEMONOD." Proc. Second International Seminar on Offshore Mineral Resources. Brest, France: March 19-23.

Legoux, P.C. 1981. "Legal Aspects of Mining Development in Developing Countries." Natura1 Resources Forum 5(2): 167-179.

Leipziger, D.M. and J.L. Mudge. 1976. Seabed Mineral Resources and the Economic Interests of Developing Countries. Cambridge: Ballinger.

Leitzinger, J.J. and J.E. Stiglitz. 1984. "Information Externalities in $0 i 1$ and Gas Leasing." Contemporary Policy Issues 5: 44-57.

Leland, H.E. 1978. "Optimal Risk Sharing and the Leasing of Natura1 Resources, With App1ication to 0i1 and Gas Leasing on the OCS." The Quarterly Journal of Economics 92(August): 413-438.

Lenoble, J.P. 1980. "Polymetallic Nodules Resources and Reserves in the North Pacific from the Data Collected by AFERNOD." Proc. Oceanology Internationa1 80.

Lense, A.H. 1968. "Samp1ing Minerals of the Ocean Floor." Mining Engineering $20(8): 54-57$.

Leontief, W. et a1. 1982. Techniques for Consistent Forecasting of Future Demand for Major Minerals Using an Input-Output Framework. Minera1 Data Analysis Contract Report, Bureau of Mines, U.S. Department of the Interior. New York: Institute for Economic Analysis, New York University.

Leshy, J.D. 1986. The Mining Law: A Study in Perpetual Motion. Baltimore: Johns Hopkins University Press for Resources for the Future.

Lévy, J.P. 1979. "The Evolution of a Resource Policy for the Exploitation of Deep Sea-Bed Minerals." Ocean Management 5: 49-78.

Lévy, J.P. 1972. "Les Ressources Minérales Des Fonds Marins Internationaux." Revue Française de Pénergie 23: 417-427.

Lévy, J.P. and N.A. Odunton. 1984. "Economic Impact of Sea-Bed Mineral Resources Development in Light of the Convention on the Law of the Sea." Natura1 Resources Forum 8: 147-161. 
Lewis, J.D. 1980. "The Deep Sea Resources." In R.B. Lillich and J.N. Moore (eds.) Readings in Internationa1 Law: 529-550.

Li, C.Y. and M.J. Valencia. 1983. Second Workshop on the Geological and Hydrocarbon Potential of the South China Sea and Possibilities of Joint Development. Honolulu: East-West Center, August 22-26.

Libby, F. 1969. "Gold in the Sea." Sea Frontiers 15(4): 232-241.

Linebaugh, R.M. 1982. "Ocean Mining in the Soviet Union." Marine Technology Society Journa1 14(1): 20-24.

Loftas, T. 1978. "UNCLOS and Ocean Mining Molehill or Mountain." Marine Policy 2(2): 86 .

Long, H.D. 1969. "Status of Mineral Resources on the Ocean Floor." California Western Law Review 5(2): 299-312.

Lonsdale, P.F., R. Batiza and T. Simkin. 1982. "Metallogenesis at Seamounts on the East Pacific Rise." Marine Technology Society Journa1 16(3): 54-61.

Loth, D. 1938. Public Plunder: A History of Graft in America. New York: Carrich \& Evans.

Lova1d, J.L. 1975. "In Search of an Ocean Regime: The Negotiating in the Genera1 Assemb1y's Sea-Bed Committee, 1968-1970." Internationa1 Organization 29: 681-709.

Lowe, A.V. 1982. "Deepsea Mining: The 1982 Convention." Presented at The Technica1-Lega1 Aspects of Sea-Bed Mining. London: June 30.

Lowe, A.V. 1981. "1st Deep Seabed Mining Workshop, Paris, 8-10 December 1980." Marine Policy 5(4): 333-334.

Luce, C.F. 1968. "The Development of Ocean Minerals and the Law of the Sea." Natura1 Resources Lawyer 1(3): 29-35.

Lück, K. 1982. "Deep-Sea Mining: Practical Technological Developments in Ocean Mining." Presented at The Technical-Legal Aspects of Sea-Bed Mining. London: June 30.

Lück, K. and Z. Nawab. 1981. "Metalliferous Sediments in the Atlantis II Deep--Recovery and Selected Problems." I0 81-403/01. Proc. Interocean '81: 116-122.

Luepke, G. (ed.). 1985. Economic Analysis of Heavy Minerals in Sediments. Van Nostrand Reinhold Company: Melbourne, Australia.

Luoma, R.T. 1983. "A Comparative Study of National Legislation Concerning the Deep-Sea Mining of Manganese Nodules." Journal of Maritime Law and Commerce 14(2): 243-268. 
Luternauer, J.L. and O.H. Pilkey. 1967. "A North Carolina Shelf Phosphate Deposit of Possible Commercial Interest." Southeastern Geology 8(1): $33-51$.

MacDonald, S. 1979. The Leasing of Federal Lands for Fossil Fue1 Production. Baltimore: Johns Hopkins University Press.

MacDonald, E.H. 1981. "Offshore Minerals other than Hydrocarbons in Southeast Asia." In C.L. Sien and C. MacAndrews (eds.) Southeast Asian Seas: Frontiers for Development, p. 51-74.

MacDonald, E.H. 1971. "Special Volume: Detrital Heavy Minerals." CCOP Technical Bulletin 5(June).

R.T. Stone and T.J. MacGi11vray. 1986. Economic Assessment and Review of the U.S. Exclusive Economic Zone (EEZ). Presented at the Fourth Anual Circum-Pacific Energy and Minerals Conference. Singapore.

MacKenzie, B.W. 1980. Looking for the Improbable Needle in a Haystack: The Economics of Base Metal Exploration in Canada. Kingston, Ont.: Center for Resource Studies, Queen's University.

MacKenzie, B.W., D.W. Davis and M.L. Bilodeau. 1986. Effects of Location on the Competitive Position of Mineral Exploration and Development in Canada. Kingston, Ont.: Centre for Resource Studies, Queen's University.

Mackenzie, B.W. and R. Wooda11. 1984. "Economic Productivity of Base Metal Exploration in Australia and Canada." Paper presented at Expert Group Meeting on the Economics of Mineral Exploration. Laxenburg, Austria: International Institute for Applied Systems Analysis (December 5-7, 1983).

MacLean, J.L. 1971. "The Great Barrier Reef IV: Mineral Resources." Australian Fisheries 30(1): 14-15.

Magnuson, A.H., J.E. Flipse, F.C. Brown, and B.V. Andrews. 1985. Economic Analysis of Deep Seabed Mining Systems: Effects of Production Rate, Inflation and Depletion Using a Revised Financial Model. TAMU-SG-85-203. College Station, Tex.: Texas A\&M University Sea Grant College Program.

Mahmud, A.A. 1983. "The Development of Non-living Resources: Problems and Opportunities for Marine Regionalism in Southeast Asia: The Malaysian Perspective." In D.M. Johnston et a1. (eds.) International Symposium on the New Law of the Sea in Southeast Asia. Halifax, pp. 73-81.

Maktouff, L. 1984. "Deep-Sea Mining: Reflections on Selected Legal and Financial Issues." Proc. 2nd International Seminar on Offshore Mineral Resources. Brest, France: GERMINAL, March 23.

Malahoff, A. 1985. "Hydrothermal Vents and Polymetallic Sulfides of the Galapagos and Gorda/Juan de Fuca Ridge Systems and of Submarine Volcanoes." Biologica1 Society of Washington Bulletin 6: 19-41. 
Malahoff, A., 1982. "The Ocean Floor, Our New Frontier: A Scientific Viewpoint." Marine Technology Society Journa1 16(3):3-4.

Malenbaum, W. 1978. Wor1d Demand for Raw Materials in 1985 and 2000. New York: McGraw-Hil1.

Maley, T.S. 1983. Handbook of Mineral Law. 3rd Edition. Boise, Id.: Mineral Land Publications.

Malone, T.C., et. a1. 1973. "Potential Environmental Impact of ManganeseNodule Mining the Deep Sea." Proc. Fifth Offshore Technology Conference, Vo1. 2. Dallas, pp. 129-138.

Manansala, M.C. 1983. "The International Seabed in the Law of the Sea: Some Views from Developing Countries." In C.H. Park (ed.) The Law of the Sea in the 1980's: 150-163.

Manganese Nodule Deposits in the Pacific. 1973. Proceedings of the Workshop, October 6-17, 1972. Honolulu: University of Hawaii.

Mangone, G.J. (ed.) 1984. American Strategic Minerals. New York: Crane Russak.

Manheim, F.T. 1986. "Marine Coba1t Resources." Science 232: 600-608.

Manheim, F.T. 1979. Potential Hard Mineral and Associated Resources on the Atlantic and Gulf Continenta1 Margins. PB81-192643. Woods Hole, Mass.: U.S. Geological Survey.

Manheim, F.T. 1972. Mineral Resources off the Northeastern Coast of the United States. U.S. Geologica1 Survey Circular 669. Reston, Va.: U.S. Department of the Interior.

Manheim, F.T. and H.D. Hess. 1981. "Hard Mineral Resources Around the U.S. Continental Margin". OTC 4131. Proc. Offshore Technology Conference. Houston: May 4-7.

Manheim, F.T., T.H. Ling and C.M. Lane. 1983. "An Extensive Data Base for Cobalt-Rich Ferromanganese Crusts from the World Oceans." Proc. Oceans '83. San Francisco.

Manser, R. 1981. "Bleak Future Faces Nodule Mining." Metal Bulletin Monthly 131 (November): 71-85.

Manthy, R.S. 1978. Natural Resource Commodities--A Century of Statistics. Baltimore: Johns Hopkins University Press for Resources for the Future.

Marcoux, J.M. 1973. "Seabed Mineral Resource Production and the Free Market." Natural Resources Lawyer 6(2): 217-248.

Marine Board. 1977. Priorities for Research in Marine Mining Technology. Report No. ADA-042-359. Washington: Nationa1 Research Council, National Academy of Sciences. 
Marine Board. 1975. Mining in the Outer Continental Shelf and in the Deep Ocean. Washington: Nationa1 Research Council, National Academy of Sciences.

Marine Ecosystems Analysis Program (MESA), 1977. Deep Ocean Mining Environmental Studies (DOMES): Project Development Plan. Boulder, Co1o.: MESA Program Office.

Marine Industry Advisory Service. 1976. Offshore Mining of Sand and Gravel. Opportunity Brief No. 2. Report No. MITSG 76-6. Cambridge, Mass.: MIT Sea Grant Program.

Marine Mineral Resources. 1985. Marine Technology Society Journa1 19(4): Special issue.

Marjoram, T. 1984. "The Potential Impacts of the Exploitation of New Ocean Resources on the Pacific." C. Gopalakrishnan (ed.). The Emerging Marine Economy of the Pacific. Boston: Ann Arbor Science, Butterworth Publishers.

Marjoram, T. 1979. "Nodules and Scandinavia--Mining Opportunities." Marine Policy 3(4): 313-315.

Marjoram, T. et a1. 1981. "Manganese Nodules and Marine Technology." Resources Policy 7: 45-57.

Markussen, J.M. 1985. "Indian Plans for Commercial Exploitation of Polymetallic Nodule Deposits in Central Indian Basin." The Fridtjof Nansen Institute Newsletter 2: 6-12.

Markussen, J.M. 1984. "Mineral Resources on the Deep-Sea F1oor-Introduction." Internasjona1 Politikk 4: 4-8.

Markussen, J.M. 1984. "Deep Seabed Minerals--Status and Perspectives for Commercial Exploitation." Internasjonal Politikk 4: 9-42.

Markussen, J.M. 1981. "Norwegian Shipping Industry Attitudes Toward and Plans for Involvement in the Deep Ocean Nodule Mining Industry." Internasjona1 Politikk 1981(1): 41-58.

Marsh, J.B. 1984. "The Potential Economic Impact of Technological Progress on the Development of Manganese Nodule Mining." Gopalakrishnan, C. (ed.). The Emerging Marine Economy of the Pacific. Boston: Ann Arbor Science, Butterworth Publishers.

Marsh, J.B. 1983. "A Model of Deepsea Mining." In C.H. Park (ed.) The Law of the Sea in the 1980s, pp. 209-239.

Marsh, J.B. 1981. "The Production and Marketing of Manganese Nodules: The Potential for Intra-Industry Impact." In W.F. Gossling (ed.) Input-Output and Marketing: International Trade in Industrial Products. East Anglia, England: Input-Output Research Association, University of East Anglia. 
Marston, G. 1982. "United Kingdom: Legislation on Deep Sea Mining." Journa1 of Wor1d Trade Law 16: 86-90.

Martin, C. 1975. "Newfoundland's Case on Offshore Minerals." Ottawa Law Review 7: 34-61.

Martin, H.J. 1981. "Deep-Sea Mining Between Convention and National Legislation". Ocean Development and International Law 10(1-2): 175-185.

Martin, R.E. 1982. "Monopoly Power and the Recycling of Raw Materials." The Journa1 of Industria1 Economics 30(4): 405-419.

Mashayekhi, M. 1985. "The Present Legal Status of Deep Sea-Bed Mining." Journa1 of Wor1d Trade Law 19: 229-250.

Mason, C.F. 1986. "Exploration, Information, and Regulation in an Exhaustible Minera1 Industry." Journal of Environmental Economics and Management 13: 153-166.

Masters, C.D. 1985. World Petroleum Resources--A Perspective. Geological Survey Open-File Report 85-248. Reston, Va.: U.S. Geological Survey.

Masters, C.D., D.H. Root and W.D. Dietzman. 1983. Distribution and Quantitative Assessment of World Crude-0il Reserves and Resources. Open File Report 83-728. Reston, Va.: U.S. Geological Survey.

Mayer, C.J. and Riley, G.A. 1985. Public Domain, Private Dominion: A History of Public Mineral Policy in America. San Francisco: Sierra Club Books.

McDivitt, J.F. and G. Manners. 1974. Minerals and Men: An Exploration of the World Minerals. Baltimore: Johns Hopkins University Press for Resources for the Future.

McDonald, S.L. 1979. The Leasing of Federal Lands for Fossil Fue1 Production. Baltimore: Johns Hopkins University Press for Resources for the Future.

McFadden, E.J. 1986. "The Collapse of Tin: Restructuring a Failed Commodity Agreement." American Journal of International Law 80: 811-830 (1986).

McGarry, J.F. and M.J. Brown. 1981. An Analysis of State and Federal Laws Applicable to Manganese Nodule Processing on the U.S. Gulf Coast. Contract report. Rockville, Md.: Office of Marine Minera1s, NOAA, U.S. Department of Commerce.

McKelvey, V.E. 1986. Subsea Mineral Resources. Bulletin 1689. Denver: U.S. Geologica1 Survey.

McKelvey, V.E. 1980. "Seabed Minerals and the Law of the Sea." Science 209: 464-472. 
McKelvey, V.E. 1980. Principles of a Resource/Reserve Classification for Minerals. USGS Circular 831 (A revision of the classification system published as USGS Bulletin 1450-A). Arlington, Va.: U.S. Geological Survey.

McKelvey, V.E. 1968. "Mineral Potential of the Submerged Parts of the U.S." Ocean Industry 3(9): 37-43.

McKelvey, V.E. 1968. "Mineral Potential of the Submerged Parts of the U.S." In Keiffer, E. (ed.) Symposium Proceedings of Mineral Resources of the World Ocean. Narragansett Marine Laboratory Occasional Publication No. 4, pp. 31-38.

McKelvey, V.E. 1968. Minerals in the Sea--A Comprehensive Report on the Mineral Potential of the Submerged Parts of the United States. Houston: Gulf Publishing Company, 6p.

McKelvey, V.E. and L. Chase. 1966. "Selecting Areas Favorable for Subsea Prospecting." Trans. Second Annual Conference of Marine Technology Society, Washington, pp. 44-60.

McKelvey, V.E. and C. Philips. 1969. "August Session of U.N. Sea-Bed Committee Held at New York." U.S. Department of State Bulletin 61: 285-294.

McKelvey V.E. and F.F.H. Wang. 1970. World Subsea Mineral Resources. Miscellaneous Geologic Investigations Map I-632. Preliminary Maps and Discussion; Second Printing, Slightly Revised. Washington: U.S. Geologica1 Survey.

McKelvey, V.E. et a1. 1969. Subsea Mineral Resources and Problems Related to Their Development. U.S. Department of the Interior, Geological Survey Circular 619. Washington.

McMains, H. and L. Wilcox (eds.). 1978. Alternative for Growth: The Engineering and Economics of Natural Resource Development. Nationa1 Bureau of Economic Research. Cambridge, Mass: Ballinger.

McMurray, G. 1986. "The Gorda Ridge Technical Task Force: A Cooperative Federa1-State Approach to offshore Mining Issues." Marine Mining 5(4): 467-475.

McNichols, W.J. 1971. Legal Problems Regarding the Extraction of Minerals (Including 0i1 and Gas) From the Continental Shelf. Sea Grant Technical Bulletin No. 14. Miami: University of Miami.

Mead, W.J. 1976. "Pricing and Buyer Selection Alternatives." In W.A. Vogeley (ed.) Economics of the Mineral Industries. 3rd Edit. New York: Society of Mining Engineers, American Institute of Mining, Metallurgical and Petroleum Engineers, pp. 648-672. 
Mead, W.J. et a1. 1986. Offshore Lands: $0 i 1$ and Gas Leasing and Conservation on the Outer Continental She1f." San Francisco: Pacific Institute for Public Policy Research.

Mead, W.J., A. Moseidjord and P.E. Sorenson. 1984. "Efficiency in Leasing." In P. Tempest (ed.) International Energy Markets. London: Graham \& Trotman.

Mead, W.J., A. Moseidjord and P.E. Sorenson. 1983. "Competition in Outer Shelf $0 i 1$ and Gas Lease Auctions: A Statistical Analysis of Winning Bids." Natura1 Resources Journal 26(Winter): 95-111.

Mead, W.J., A. Moseidjord and P.E. Sorenson. 1983. "The Rate of Return Earned by Lessees Under Cash Bonus Bidding for OCS Oil and Gas Leases." The Energy Journa1 4(4): 37-52.

Mead, W.J., D.D. Muraoka and P.E. Sorenson. 1982. "The Effect of Taxes on the Profitability of U.S. Oil and Gas Production: A Case Study of the OCS Record." National Tax Journal 35: 21-29.

Mead, W.J. and P.E. Sorensen. 1968. "Externalities in Ocean Minera1 Resource Development. Proc. Fourth Annual Conference of Marine Technology Society: pp. 9-16.

Mead, W.J., P.E. Sorenson and A. Moseidjord. 1982. Competitive Bidding Under Asymmetric Information. Final Report. USGS Contract No. 14-08-0001-18678. Santa Barbara, Calif.: Community and Organization Research Institute, University of California.

Mead, W.J., P.E. Sorenson, R.O. Jones and A. Moseidjord. 1980. Competition and Performance in OCS $0 i 1$ and Gas Lease Sales and Lease Development, 1954-1969. Fina1 Report. Santa Barbara, Calif.: Community and Organization Research Institute, University of California.

Mead, W.J., P.E. Sorenson, A. Moseidjord, and D. Muraoka. 1980. Additiona1 Studies of Competition and Performance in OCS Oil and Gas Lease Sales. Final Report. Santa Barbara, Calif.: Community and Organization Research Institute, University of California.

Meese, S.A. 1983. "LOS and 'Other Minera1s.'" Marine Policy 7: 123-124.

Meiser, H.J. and E. Mue11er. 1973. "Manganese Nodules--A Further Resource to Cover the Mineral Requirements?" Meerestechnik 4: 145-150.

Menard, H.W. 1969. The Configuration of the Ocean Floor and Its Subsoil: Geopolitica1 Implications. Paper presented at Symposium on the International Regime of the Sea-bed. $3 \mathrm{p}$.

Menard, H.W. and Frazer, J.Z. 1978. "Manganese Nodules on the Sea Floor: Inverse Correlation Between Grade and Abundance." Science 199: 969-971.

Mero, J.L. 1977. "Economic Aspects of Nodule Mining." In Marine Manganese Deposits. Elsevier Oceanographic Series No. 15, pp. $327 \overline{-356 .}$ 
Mero, J.L. 1970. "A Legal Regime for Deep Sea Mining." San Diego Law Review $7(3): 488-503$.

Mero, J.L. 1970. "Will Ocean Mining Prove Commercial?" Offshore 31(4): 118, 120-134.

Mero, J.L. 1968. "Mineral Deposits in the Sea." Natural Resources Lawyer 1(3): 130-137.

Mero, J.L. 1968. "Oceanic Mineral Resources." Future, the Journal of Forescasting and Planning 1(2): 125-141.

Mero, J.L. 1968. "Seafloor Minera1s: A Chemical Engineering Cha1lenge." Chemical Engineering 75: 73-80.

Mero, J.L. 1968. "Marine Mining Deposits of Economic Interest." In Proceedings of Ocean Mining Symposium, 1967. Sponsored by M.J. Richardson, Inc., p. 85-106.

Mero, J.L. 1967. "Ocean Mining--Here's Where We Stand." Steel 160(20): 45-49.

Mero, J.L. 1967. "Alternatives for Mineral Exploitation." Alexander, L.M., ed. The Law of the Sea: The Future of the Sea's Resources. Proceedings of the Second Annual Conference of the Law of the Sea Institute. Kingston: University of Rhode Island, p. 94-97.

Mero, J.L. 1966. "The Future of Mining the Sea." Oceanology Internationa1 1: 72-78.

Mero, J.L. 1966. "Review of Mineral Values On and Under the Ocean F1oor." In Proceedings of Second Annual Conference of the Marine Technology Society. Washington, p. 61-78. Mero, J.L. 1965. The Mineral Resources of the Sea. New York: E1sevier
Publishing.

Mero, J.L. 1964. "Mineral Resources of the Sea." New York Academy of Sciences, Transactions March: 525-544.

Metallgesellschaft Aktiengesellschaft. 1984. Metallstatistik 1973-1983 71. Frankfurt am Main: Metal1gesellschaft AG.

Meyer, G.E. et a1. 1973. "The Marine Nodules Project: Spotlights From the View of Process Engineering." Meerestechnik 4: 155-157.

Meylan, M.A., B.K. Dugolinsky and L. Fortin. 1976. Bibliography and Index to Literature of Manganese Nodules (1874-1975). IDOE-NSF Manganese Nodule Technical Report No. 14. Washington: NOAA with State of Hawaii Department of Planning and Economic Development.

Mikese11, R.F. 1987. Nonfue1 Minerals: Foreign Dependence and National Security. Ann Arbor: University of Michigan Press. 
Mikese11, R.F. 1984. Petroleum Company Operations and Agreements in the Developing Countries. Washington: Resources for the Future.

Mikese11, R.F. 1979. The Wor1d Copper Industry: Structure and Economic Analysis. Baltimore: Johns Hopkins University Press for Resources for the Future.

Mikhailov, S. 1971. Marine Ores in the USSR. Moscow: Novosti Press Agency.

Miles, E.L. and S. Allen (eds.) 1981. The Law of the Sea and Ocean Development Issues in the Pacific Basin. Proc. Law of the Sea Institute Fifteenth Annual Conference. Honolulu: Law of the Sea Institute.

Miles, E.L., J.E. Flipse, and G. Pontecorvo. 1974. The Significance of Manganese Nodules in the World Market and Policies for Their Utilization. J. Seward Johnson Lecture in Marine Policy. Woods Hole, Mass.: Marine Policy and Ocean Management Program, Woods Hole Oceanographic Institution.

Miller, E.P. and J.H. Delehant. 1980. "Deep Seabed Mining Government Guaranteed Financing Under the Maritime Aids of the Merchant Marine Act, 1936, as an Alternative to Treaty-Related Loss Compensation." Journal of Maritime Law and Commerce 11(4): 453-474.

Minera1 Resources Branch. 1980. The Future of Nickel and The Law of the Sea. Mineral Policy Background Paper No. 10. Ottawa, Ont.: Ministry of Natural Resources.

Minerals Management Service. 1987. Briefing Book: OCS Marine Mining. Distributed at the OCS Policy Committee Meeting. San Francisco. April.

Minerals Management Service. 1987. Federal offshore Statistics: 1985 . Annual Series 1984-1987. Washington: U.S. Department of the Interior.

Minerals Management Service. 1987. Draft Environmental Impact Statement: Proposed Marine Mineral Lease Sale in the Hawaiian Archipelago and Johnston Island Exclusive Economic Zones. Reston, Va.: U.S. Department of the Interior.

Minerals Management Service. 1985. "Resource Assessment: Cobalt-Rich Manganese Crust Potentia1." oCS Study MMS 85-0006. Long Beach, California.

Minerals Management Service. 1985. Leasing of Nonenergy Minerals in the Outer Continental Shelf. Advanced Notice of Proposed Rulemaking. Federal Register 50(76): 15590-91, Apri1 19.

Minerals Management Service. 1984. Call for Information to Delineate Areas of Interest for Preparation of an Environmental Impact Statement on the Exploration for and Possible Recovery of Cobalt-Rich Manganese Crusts in the Hawaiian Exclusive Economic Zone. Federal Register 49(168):

34099-101, August 28. 
Minerals Management Service. 1983. Final Environmental Impact Statement: Proposed Arctic Sand and Gravel Lease Sale. Reston, Va.: U.S. Department of the Interior.

Minerals Management Service. 1983. Draft Environmental Impact Statement: Proposed Polymetallic Sulfide Minerals Lease Offering: Gorda Ridge Area offshore Oregon and Northern California. Reston, Va.: U.S. Department of the Interior.

Minerals, Materials and Fuels Subcommittee. 1974. Mineral Resources of the Deep Seabed--Part 2. Washington: Senate Committee on Interior and Insular Affairs, U.S. Congress.

Miron, G. 1971. "The Outer Continental Shelf-Managing (or Mismanaging) Its Resources." Journal of Maritime Law and Commerce 2: 267.

Miron, G. 1969. "Proposed Regimes for Exploration and Exploitation of the Deep-Seabed." Proc. Fourth Annual Law of the Sea Institute, pp. 98-109.

Miron, G. 1969. "The Management of the Mineral Resources of the Ocean Floor-A Critique of Certain Aspects of the Proposal of the Commission on Marine Science, Engineering and Resources." Stanford Journal of International Studies 4: 32-45.

Mishra, C.P. et a1. 1985. Cobalt Availability--Market Economy Countries. IC 9012. Washington: Minerals Availability Progam Appraisal, U.S. Bureau of Mines.

Molitor, M.R. 1982. "The U.S. Deep Seabed Mining Regulations: The Legal Basis for an Alternative Regime." San Diego Law Review 19: 599-612.

Moncrieff, A.G. and D.P.P. Baker. 1977. Sources of Information on Manganese Nodules. Unpublished lecture manuscript presented before the Geological Society, Information Group. London: December 8.

Moncrieff, A.G. and K.B. Smale-Adams. 1974. "The Economics of First Generation Manganese Nodule Operations." Mining Congress Journal 60(12): 46-52.

Moore, J.N. 1975. "Symposium on Deep Seabed Mining--Law of the Sea--Choice and a Challenge." Virginia Journal of International Law 15(4): 791-93.

Moore, J.R. 1983. "Marine Hard Minerals Resources--Progress and Problems." Proc. Oceans 183. San Francisco: MTS and IEEE, Pp. 1145-1150.

Moore, J.R. 1979. "Marine Placers: Exploration Problems and Sites for New Discoveries." Proc. 1st Symposium on Offshore Mineral Resources. Orleans, France: BRGM and GERMINAL.

Moore, J.R. 1972. "Exploitation of Ocean Mineral Resources--Perspectives and Prediction." Royal Society of Edinburgh Proceedings 72(19): 193-206. 
Moore, J.R. and M.J. Cruickshank. 1973. "Identification of Technological Gaps in Exploration of Marine Ferromanganese Deposits." Inter-University Program of Research on Ferromanganese Deposits of the Ocean F1oor. Phase I Report. Washington: Seabed Assessment Program, International Decade for Ocean Exploration, National Science Foundation.

Moore, J.R. and R.M. Owen. 1976. "Sediment Dispersal Patterns as Clues to Placerlike Platinum Accumulation In and Near Chagvan Bay, Alaska." Proc. Eighth Annual offshore Technology Conference: 307-318.

Morgan, J.R. and M.J. Valencia (eds.) 1983. Atlas for Marine Policy in Southeast Asian Seas. Los Angeles: University of California Press.

Morgenstein, M. (ed.) 1973. Papers on the Origin and Distribution of Manganese Nodules in the Pacific and Prospects for Exploration. An International Symposium organized by the Valdivia Manganese Exploration Group and the Hawaii Institute of Geophysics. Honolulu: University of Hawaii, 173p.

Morgenstein, M. and J. Andrews. 1971. "Manganese Resources in the Hawaiian Region." Marine Technological Society Journal 5(5): 27-30.

Morley, I.W. 1981. Black Sands: A History of the Minera1 Sand Mining Industry in Eastern Australia. Lawrence, Mass.: Univ, of Queensland Press.

Moss, R.S. 1984. "Insuring Unilaterally Licensed Deep Seabed Mining Operations Against Adverse Rulings by the International Court of Justice: An Assessment of Risk." Ocean Development and International Law 14: 161-191.

Mott1, M.J. 1983. Physica1, Chemical, and Geologic Constraints on the Formation of Polymetallic Sulfide Deposits on the Seafloor. Working Paper. Woods Hole, Ma.: Woods Hole Oceanographic Institution.

Mphaisha, C.J.J. 1980. "Minerals Under the Sea - An Analysis of International Regulatory Systems." African Social Research 1980(3): 811-829.

Muangkoe, M. 1983. Marine Resource Development in Thailand. Unpublished manuscript. 5th Biennial Meeting of the Agricultural Economics Society of Southeast Asia. Bangkok, Thailand, November 16-18.

Muench, F. 1970. "Lex Lata of Deep Sea Mining." Presented at Pacem in Maribus Preparatory Conference on the Legal Framework and the Continental Shelf. Kingston, R.I.

Muirhead, M. and B. Sternberg. 1985. Location and Delineation of Seafloor Polymetallic Sulphide Deposits Using the Induced Polarization Method. Presentation at Underwater Mining Institute. Halifax, Nova Scotia, October 21.

Murdoch, A. 1943. Boom Copper. The Story of the First U.S. Mining Boom. New York: The MacMillan Company. 
Murphy, J.M. 1976. "Deep Ocean Mining - Beginning of a New Era." Case Western Reserve Journal of International Law 8(1): 46-68.

Murphy, J.M. 1976. "Deep-Sea Mining Legislation Viewed as Urgent." Mining Congress Journal 62(3): 40-41.

Mustafa, Z. 1978. "Ocean Mining and Protection of the Marine Environment of the Red Sea." Proc. Offshore Technology Conference. OTC 3188. Houston: May 8-11.

Mustafa, Z. et a1. 1984. "Economic Interest of Hydrotherma1 Deposits: The Atlantis II Project." Proc. 2nd International Seminar on Offshore Mineral Resources. Brest, France: GERMINAL, Pp. 509-539.

National Advisory Commission on Oceans and Atmosphere. 1984. The Exclusive Economic Zone of the United States: Some Immediate Policy Issues. Washington.

National Advisory Committee On Oceans And Atmosphere. 1983. Marine Minerals: An A1ternative Mineral Supply. National Ocean Goals and objectives for the 1980s. Washington.

National Oceanic and Atmospheric Administration, Department of the Interior, and Smithsonian Institution. 1985. Exclusive Economic Zone Symposium: Exploring the New Ocean Frontier. October 2-3. Washington.

Nationa1 Oceanic and Atmospheric Administration. 1976. Proc. Marine Minerals Workshop. Rockville, Md.: U.S. Department of Commerce.

National Petroleum Council. 1975. Ocean Petroleum Resources. Washington: National Petroleum Council.

National Research Council. 1986. Known Geologic Structures Under the Minera1 Leasing Act: Interpreting and Applying the Term "Known Geologic Structure of a Producing $0 i 1$ and Gas Field". Washington: National Academy Press.

National Research Council. 1984. Deep Seabed Stable Reference Areas. Washington: National Academy Press.

National Research Council. 1982. Interim Report on Stable Reference Areas: Report of a Meeting, March 28-29, 1982. Washington: National Academy Press.

National Research Council. See also: Marine Board.

National Security Industrial Association. 1968. Report of the Coastal States Conference on the Multiple Use Approach to Ocean Mining Law. Portland, Oregon.

Nelson, R.H. 1983. The Making of Federal Coal Policy. Durham, N.C.: Duke Press Policy Studies. 
Nelson, R.H. 1982. "The Public Lands." Portney, P.R. and R.B. Haas (eds.). Current Issues in Natural Resource Policy. Washington: Resources for the Future.

Netherlands Branch of International Law Association. 1966. "The Exploration and Exploitation of Minerals on the Ocean Bed and its Subsoil." In Report, Fifty-Second Conference of the International Law Association (L. Bouchez, rapporteur), p. 793-798.

Neuman, L.D. and P.A. Rona. 1976. "Energy and Mineral Resources of the Pacific Region in Light of Plate Tectonics." Ocean Management 3(1): 57-78.

Newlin, A.C. 1980. "An Alternative Legal Mechanism for Deep Sea Mining." Virginia Journa1 of Internationa1 Law 20(2): 257-264.

New York Office of General Services. Undated. Removing Material from Underwater Lands. Albany, New York.

Newton, W.F. 1971. "Seabed Resources: The Problems of Adolescence." San Diego Law Review 8(3): 551-572.

Nigre11i, V.J. 1978. "Ocean Mineral Revenue Sharing." Ocean Development and International Law 5(2-3): 153-

Niino, H. 1970. "On the Mineral Resources of the Sea F1oor Around the Japanese Islands and the Problems of Banks and Rocks Situated Outside the Continental Shelf." In J. Sztucki, ed., Proceedings of Symposium on the International Regime of the Sea-Bed, Rome, 1969. Rome: Accademia Nazionale dei Lincei, p. 65-73.

Noakes, J.E., et a1. 1974. "Locating Offshore Mineral Deposits by Natura1 Radioactive Measurements." Marine Technical Society Journa1 8: 36-39.

Noakes, J.E. and J.L. Harding. 1971. "New Techniques in Seafloor Mineral Exploration." Marine Technology Society Journal 5(6): 41-44.

Noakes, L.C. 1977. "Review of Provenanace for Mineral Sands and Tin in Southeast Asia." CCOP Technical Bulletin 11(October).

Noakes, L.C. 1972. "Preliminary Report on Reconnaissance of Heavy Minera1 Sands in Southern Viet-Nam." CCOP Technical Bulletin 6(July).

Noakes, L.C. 1971. "I. Offshore Minera1 Resources--A Genera1 Review." CCOP Technical Bulletin 5: 1-12.

Non-Living Resources. Part 3 -- Mineral Development on State Tide Land and Submerged Lands. 1971. Sacramento: Department of Navigation and Ocean Development, 131p.

Norberg, J.R. 1985. A Review of Copper, Lead, and Zinc Processing Technologies, and Domestic and Foreign Smelting and Refining Facilities. Spokane, Wash.: Western Field Operations Center, U.S. Bureau of Mines. 
Normark, W.R. et a1. 1986. "Submarine Fissure Eruptions and Hydrotherma1 Vents on the Southern Juan de Fuca Ridge: Preliminary Observations from the Submersible Alvin." Geology 14: 823-827.

Nossaman, Krueger \& Marsh. 1980. An Analysis of Applicable Law Concerning Seabed Mineral Processing in California, Washington, Oregon and Alaska. Contract report. Rockville, Md.: Office of Marine Minerals, NOAA, U.S. Department of Commerce.

Nyhart, J.D. 1975. "The Interplay of Law and Technology in Deep Seabed Mining Issues." Virginia Journal of International Law 15(4): 827-868.

Nyhart, J.D., L.N. Antrim, A. Capstaff, A.D. Kohler and D. Leshaw. 1978. A Cost Model of Deep Ocean Mining and Associated Regulatory Issues. MITSG-78-4. Cambridge, Mass.: MIT Sea Grant Program.

Nyhart, J.D. and M.S. Triantafyllou 1983. A Pioneer Ocean Mining Venture. MITSG-83-14. Cambridge, Mass.: MIT Sea Grant Co1lege Program.

Nyhart, J.D. et al. 1982. Toward Deep Ocean Mining in the Nineties. MITSG-82-1. Cambridge, Mass.: MIT Sea Grant College Program.

Ocean Association of Japan. 1978. The Deep Seabed and Its Mineral Resources. Proc. 3rd International Ocean Symposium. Tokyo.

Ocean Economics and Technology Branch. 1987. Delineation of Mine Sites and Potential in Different Sea Areas. Seabed Minerals Series Vol. 4. London: Graham \& Trotman Ltd. in cooperation with the United Nations.

Ocean Economics and Technology Branch. 1986. Analysis of Processing Technology for Manganese Nodules. Seabed Minerals Series Vol. 3. London: Graham \& Trotman Ltd. in cooperation with the United Nations.

Ocean Economics and Technology Branch. 1984. Analysis of Exploration and Mining Technology for Manganese Nodules. Seabed Minerals Series Vol. 2. London: Graham \& Trotman Ltd, in cooperation with the United Nations.

Ocean Economics and Technology Branch. 1982. Assessment of Manganese Nodule Resources, Seabed Minerals Series Vol. 1. London: Graham \& Trotman in cooperation with the United Nations.

Ocean Economics and Technology Branch. 1982. Industrial Demand for Metals: Projections Under Alternative International Development Scenarios. Unpub1ished manuscript. New York: Department of International Economic and Social Affairs, United Nations.

Ocean Minerals and Energy Division. 1984. Deep Seabed Mining: Fina1 Regulations for Exploration Licenses (Revised as of January 1, 1983). Washington: Office of Ocean and Coastal Resource Management, NOAA, U.S. Department of Commerce.

Ocean Minerals and Energy Division. 1983. Deep Seabed Mining Report to Congress. Washington: Office of Ocean and Coasta1 Resource Management, NOAA, U.S. Department of Commerce. 
Ocean Minerals and Energy Office. 1982. Deep Seabed Mining Marine Environmental Research Plan 1981-85. Washington: NOAA, U.S. Department of Commerce.

Ocean Minerals and Energy Office. 1981. Deep Seabed Mining: Report to Congress. Washington: NOAA, U.S. Department of Commerce.

Ocean Minerals and Energy Office. 1981. Deep Seabed Mining: Final Programmatic Environmental Impact Statement. Vols. I, II. Washington: NOAA, U.S. Department of Commerce.

Ocean Minerals and Energy Office. 1981. Deep Seabed Mining Technica1 Guidance Document. Washington: NOAA, U.S. Department of Commerce.

Ocean Minerals and Energy Office. 1981. NOAA Briefing on its Polymetallic Sulfide Deposit Research Program: Edited Presentations, December 2, 1981. Washington: NOAA, U.S. Department of Commerce.

Ocean Science News. 1974. United Nations Source Documents on Seabed Mining. Washington: Nautilus Press.

Oceanography Subcommittee. 1979. Law of the Sea. Washington: U.S. House Committee on Merchant Marine and Fisheries, 96 th Cong., 1st sess., Hearings.

Oceanography Subcommittee. 1974. Deep Seabed Hard Minerals. Washington: House Committee on Merchant Marine and Fisheries, U.S. Congress.

O'Conne11, D.P. 1982. The International Law of the Sea. Vo1. I. Oxford: Clarendon Press, pp. 457-466.

Oda, S. 1963. International Control of Sea Resources. Leyden: Sijthoff.

Oda, S. 1969. "Possible Future Regimes of the Sea-Bed Resources." Paper presented at Symposium on the International Regime of the Sea-Bed. Rome.

Odunton, N.A. 1977. "Metal Resources of Deep Sea Nodules." Natural Resources Forum 1: 285-298.

Office of Science and Technology Policy. 1983. Annual Science and Technology Report to the Congress: 1982. Washington.

Office of Technology Assessment. 1987. Marine Minerals: Exploring Our New Ocean Frontier. Washington: U.S. Congress.

Office of Technology Assessment. 1985. Strategic Materials: Technologies to Reduce U.S. Import Vulnerability. OTA-ITE-248. Washington, D.C.

Office of Technology Assessment. 1985. Oil and Gas Technologies for the Arctic and Deepwater. Congress of the United States. Washington, D.C.: U.S. Government Printing office (GPO No. 052-003-00995-1). 
Office of Technology Assessment. 1982. Globa1 Mode1s, World Futures, and Public Policy: A Critique, OTA-R-165. Washington, D.C.

Officer, C.B. 1969. "Mineral Development in the Deep Offshore Resources and Technology." In Symposium on International Business in 1969. Problems and Solutions of Private Investors Abroad. Dallas, New York: M. Bender, p. $1-8$.

Offield, T.W. 1984. "U.S. Geological Survey Marine Minerals Research." Proc. Oceans '84. Washington: MTS and IEEE.

Offshore. 1986. "Worldwide Offshore Daily Average Oil Production." Offshore (May): 120.

Ohly, D.C. 1975. "International Seabed Resources: The U.S. Position." Virginia Journa1 of International Law 15(4): 903-925.

01iver, C.D. 1981. "Interim Deep Seabed Mining Legislation: An Internationa1 Environmental Perspective." Journal of Legislation 8: 73-103.

Opland, H.N. 1962. Marine Mineral Resources. Azusa, Calif.: Aerojet General Corporation.

Oregon State University. 1978. Identification of Representative West Coast Areas for Manganese Nodule Processing Activities. Draft contract report. Rockville, Md.: Office of Marine Minerals, NOAA, U.S. Department of Commerce.

Orrego Vicuna, F. 1981. "National Laws on Seabed Exploitation: Problems of Internationa1 Law." Lawyer of the Americas 13: 139-156.

Osberger, R. and C.M. Romanowitz. 1967. "How the Off-Shore Indonesian Tin Placers are Explored and Sampled." World Mining 3(12): 24-30.

Ott, D.B. 1977. "Analysis of Deep Seabed Mining Legislation." Natural Resources Lawyer 10(3): 591-604.

Overa11, M.P. 1966, 1968. "Mining Phosphorite from the Sea." Ocean Industry 3: September 1966, 44-48; October 1968, 60-64; November 1968, 51-52.

Owen, B.E. and W.J. Kops. 1980. Impact of Policy Change on Decision in the Mineral Industry: The Case of Exploration in Manitoba. Kingston, Ont.: Center for Resource Studies, Queen's University.

Ozturgut, E. et a1. 1978. "Deep Ocean Mining of Manganese Nodules in the North Pacific: Pre-Mining Environmental Conditions and Anticipated Mining Effects." NOAA Technical Memorandum. ERL MESA-33. Boulder, Co10.: NOAA, U.S. Department of Commerce.

Padan, J.W. 1983. "Offshore Sand and Gravel Mining." OTC 4495. Proc. offshore Technology Conference. Houston. 
Padan, J.W. (ed.) 1977. New England Offshore Mining Environmental Study (Project NOMES): Final Report. Boulder, Colo.: National Oceanic and Atmospheric Administration, Environmental Research Laboratories.

Padan, J.W. 1965. Sea Floor Minerals--Curios or Wealth. Presented at the 8th National Sampe Symposium, Insulation-Materials and Processes for Aerospace and Hydrospace Applications, May 25-28, 1965, 13p.

Page, W.P. and W. Fellner. 1978. "Exploratory Techniques for the Determination of Potential Dose-Response Relationships Between Human Health and Air Pollution". Journal of Environmental Economics \& Management 5: 376

Pardo, A. 1974. "A Statement on the Future Law of the Sea in Light of Current Trends in Negotiations." Ocean Development and International Law Journal $1: 315-335$.

Park, C.F. and R.A. MacDiarmid. 1975. Ore Deposits. San Francisco: W.H. Freeman and Company.

Pasho, D.W. 1982. An Initial Analysis of Deep Seabed Mining Cost Estimates and Methods for Comparing Costs of Seabed and Land Based Nickel Production. Internal Report 92-1. Toronto: Department of Energy, Mines and Resources, Canada Oil and Gas Lands Administration.

Pasho, D.W. 1977. "Review of the Development of Deep Seabed Manganese Nodules." The Ocean Mining Report 11(7): 16-33.

Paton, A. et a1. (eds.) 1978. Sea Floor Development: Moving Into Deep Water. London: The Royal Society.

Payne, R.J. 1980. "African Economic Problems and the African Position on the Law of the Sea in Relation to Manganese Nodules." Journal of Developing Areas 15(1): 21-41.

Payne, R.J. 1978. "Mining the Deep Seabed--Politica1, Economic and Lega1 Struggle." Journal of Politics 40(4): 933-55.

Payne, R.J. and J.R. Nassar. 1982. "The New International Economic Order at Sea." Journal of Developing Areas 17(1): 31-50.

Pearce, D.W., H. Siebert and W. Ingo. 1984. Risk and the Political Economy of Resource Development. New York: St. Martin's Press.

Pearson, J.S. 1975. Ocean Floor Mining. Park Ridge, N.J.: Noyes Data Corporation.

Pehrson, G.0. 1966. "Mining Industry's Role in Development of Undersea Mining." Proc. Second Annual Conference of the Marine Technology Society: 182-196.

Pequegnat, W.E. et a1. "Deep-Sea Ironstone Deposits in the Gulf of Mexico." Journal of Sedimentary Petrology 42: 700-710. 
Peterson, D.R. and P.B. Grote. 1979. Study of Deep Ocean Mining Operational Economics. Vo1. I: Simulation, Development, and Study of the Obstacle Effect, BUMINES-OFR-95(1)-80. Vo1. II: Deep Ocean Mining Operational Simulation, BUMINES-OFR-95(2)-80. Washington: U.S. Bureau of Mines.

Peterson, G.R., D.I. Bleiwas and P.R. Thomas. 1981. Cobalt Availability-Domestic: A Minerals Availability System Appraisa1. IC 8848. Washington: Minerals Availability Program Appraisa1, U.S. Bureau of Mines.

Peterson, G.R., K.E. Porter and A.A. Soja. 1985. Primary Lead and Zinc Availability: Market Economy Countries. IC 9026. Washington: Minerals Availability Program Appraisal, U.S. Bureau of Mines.

Petters, R.A. and F.H. Brockett. 1983. "Testing of a Deep Water Mineral Recovery System." Mining Magazine (December): 446-449.

Pickering, I.G. 1983. "Managing Mining Enterprises Today and Tomorrow." NWMA 89th Annual Convention Session Papers. Spokane, Wash.: Northwest Mining Association.

Pinto, M.C.W. 1980. "The Developing Countries and the Exploitation of the Deep Seabed." Columbia Journal of World Business 15: 30-41.

Piper, D.Z. (ed.). 1977. "Deep Ocean Environmental Study--Geology and Geochemistry of DOMES Sites A, B, and C, Equatorial North Pacific." USGS Open-File Report 77-778. Menlo Park, Calif.: USGS, U.S. Department of the Interior.

Pirtle, C.E. 1981. "Alternative Regimes for Harvesting the Seabed: A Review Article." Ocean Development and International Law 9: 77-99.

Polymetallic Sulfides. 1982. Marine Technology Society Journal 16(3). Specia1 Issue.

Pontecorvo, G. 1974. "Reflections on Economics of Common Heritage of Mankind--Organization of Deep-Sea Mining Industry and Expected Benefits from Resource Exploitation." Ocean Development and International Law $2(3): 203-216$.

Post, A.M. 1983. Deepsea Mining and the Law of the Sea. The Hague: Martinus Nijhoff.

Post, A.M. 1982. "United Nations Involvement in Ocean Mining." Ocean Development and International Law 10(3-4): 275-313.

Potter, N. and F.T. Christy. 1962. Trends in Natural Resource Commodities. Baltimore: The Johns Hopkins Press for Resources for the Future.

Prain, R. 1975. Copper: The Anatomy of an Industry. London: Mining Journal Books.

Pratt, R.M. and P.F. McFarlin. 1966. "Manganese Pavements on the Blake Plateau." Science 151: 1080-1082. 
Prescott, V. 1980. "The Deep Seabed." In R.P. Barston and P.W. Birnie (eds.) The Maritime Dimension, pp. 54-75.

Prewo, V.W. 1979. "Tief seebergbau: Goldgrube, Weifser Elefant oder Trojanisches Pferd?" Die Weltwirtschaft 1: 183-196.

Pruitt, Virginia A. 1982. "Unilatera1 Deep Seabed Mining and Environmental Standards: A Risky Venture." Brooklyn Journal of International Law 8: 345-363.

Public Land Law Review Commission. 1970. One Third of the Nation's Land. Ch. 7: Mineral Resources; Ch. 11: The Outer Continental Shelf. Washington: U.S. Government Printing Office.

Quick, A.N. 1982. "Exploration Strategy: An Integral Part of Strategic P1anning." Oil \& Gas Journal (September 27): 286-300.

Rafati, R. 1985. Chapters on: "Cobalt" and "Nickel." In J.B. Donges, ed., The Economics of Deep Sea Mining. New York: Springer-Verlag.

Rafati, R. 1982. An Econometric Mode1 of the World Nicke1 Industry. Kie1 Working Paper No. 160. Kie1, West Germany: Institut für Weltwirtschaft.

Rafati, R. 1982. An Econometric Model of the World Cobalt Industry. Kiel Working Paper No. 163. Kie1: Institut für Weltwirtschaft.

Randa11, G. 1983. "Hard Mineral Taxation: Practical Problems." Idaho Law Review 19: 487-503.

Rao, T.R., N.R. Rao and M.V. Ramaraju. 1983. "Ilmenite of Black Sand Deposits of Visakhapatnam-Bhimunipatnam Beach, East Coast of India." Indian Journal of Marine Sciences 12: 220-222.

Rathgeber, D.D. 1984. "Outer Continental Shelf Leasing Policy Prevails over the California Coastal Commission." Natural Resources Journal 24: 1133-1145.

Ratiner, L.S. 1983. "The Future of Seabed Mining." Materials and Society $7(1): 45-48$.

Ratiner, L.S. 1978. "Prospects for Deep Seabed Mining." Journal of International Law and Economics 12(2): 191-94.

Ratiner, L.S. 1973. "Oil and Hard Minerals: Government Proposals." Proc. Conference on Local Impacts of the Law of the Sea. Seattle: Division of Marine Resources, University of Washington, pp. 103-111.

Ratiner, L.S. 1971. "United States Oceans Policy: An Analysis." Journal of Maritime Law and Commerce 2: 225.

Ratiner, L.S. and R.L. Wright. 1973. "United States Ocean Minera1 Resource Interests and the United Nations Conference on the Law of the Sea." Natura1 Resources Lawyer 6(1): 1-43. 
Raymond, L.C. 1964. "Valuation of Mineral Property." In E.H. Robie (ed.) Economics of the Mineral Industries. 2d edit. New York: American Institute of Mining, Metallurgical, and Petroleum Engineers, Inc.

Raymond, R.C. 1976. "Seabed Minerals and the U.S. Economy: A Second Look." Marine Technology Society Journal 10(5): 12-18.

Razavi, H. 1983. "Effect of Uncertainty on Oil Extraction Decisions." Journa1 of Economic Dynamics and Control 5: 359-370.

Reece, D.K. 1978. "Competitive Bidding for Offshore Petroleum Leases." The Be11 Journal of Economics 9(2): 369-384.

Reinganum, J.F. and N.L. Stokey. 1985. "Oligopoly Exctraction of a Common Property Natural Resource: The Importance of the Period of Commitment in Dynamic Games." International Economic Review 26(1): 161-173.

Revelle, R. 1969. "The Ocean: Its Uses and Its Role in the Emergence of the New Geology." Scientific American 221: 54-65.

Revelle, R. et a1. 1970. "Submarine Geology in Relation to the Use of the Earth's Mineral Resources." Oceanology 10(6): 749-760.

Rice, R. 1967. "Research Problems Related to Offshore Mineral Exploitation." Proc. Technology of the Sea and the Sea-Bed Conference. Harwe11, England, pp. $361-370$.

Rich, R. 1982. "A Minerals Regime for Antarctica." International and Comparative Law Quarterly 31: 709-725.

Richardson, E.L. 1981. "Law in the Making: A Universa1 Regime for Deep Seabed Mining?" Journal of Legislation 8: 199-219.

Richardson, E.L. 1981. "The United States and the Current Status of Deep Seabed Mining at the Third United Nations Conference on the Law of the Sea." Environmental Law 11: 193-209.

Riggs, S.R. 1985. "Geologic Framework of Phosphate Resources in Onslow Bay, North Carolina Continental Shelf." Economic Geology 50: 716-738.

Ritchey, J.L. 1986. Offshore Mineral Resources of the Pacific Northwest. Presented at Northwest Mining Association 92nd Annual Convention. Spokane, Wash.: December 4-6.

Ritchie, C.J. 1984. "Wide Pattern Pedis Possessio: The Expansion of Prediscovery Mineral Claim Protection in New Mexico." Natura1 Resources Journal 24 (Apri1): 437-449.

Robbins, P. 1982. Guide to Nonferrous Metals and Their Markets. 3rd edit. New York: Nichols Publishing Company.

Robertson, H.B. 1980. "A Legal Regime for the Resources of the Seabed and Subsoil of the Deep Sea: A Brewing Problem for International Lawmakers." In R.B. Lillich and J.N. Moore, Readings in International Law: 457-503. 
Rockwood, A. 1983. "The Impact of Joint Ventures on the Market for OCS Oil and Gas Leases." Journal of Industrial Economics 31(4): 453-468.

Roe1s, 0.E. 1974. "Will Nodule Mining Disturb the Marine Environment." Marine Technology Society Journal 8(8): 17-20.

Rogers, Golden, \& Halpern. 1982. State-of-the-Art Environmental Assessment Onshore Disposal of Manganese Nodule Rejects. Interagency Research Program Contract Report. Washington: NOAA, Environmental Protection Agency and Fish and Wildlife Service.

Romanowitz, C.M. "On Shore Alluvial Mining Results as a Guide to Future Offshore Mining." World Mining 7(2): 52-56.

Rona, P.A. 1986. "Mineral Deposits from Sea-Floor Hot Springs." Scientific American 254(1): 84-92.

Rona, P.A. 1984. "Exploration for Hydrotherma1 Minera1 Deposits at Seafloor Spreading Centers: U.S. Activities." Proc. 2nd International Seminar on offshore Mineral Resources. Brest, France: GERMINAL.

Rona, P.A. 1983. "Exploration for Hydrothermal Mineral Deposits at Seafloor Spreading Centers." Marine Mining 4(1): 7-38.

Rona, P.A. 1983. "Potential Mineral and Energy Resources at Submerged Plate Boundaries." Natural Resources Forum 7(4): 329-338.

Rona, P.A. 1982. "Polymeta11ic Sulfides at Seafloor Spreading Centers: A Global Overview." Marine Technology Society Journal 16(3): 81-86.

Rona, P.A. 1981. "Marine Mineral Resources." Natural Resources Forum 5(1): 89-95.

Rona, P.A. 1976. "Pattern of Hydrotherma1 Minera1 Deposition: Mid-Atlantic Ridge Crest at Latitude 26 Degrees N." Marine Geology 21(4): M59-M66.

Rona, P.A. 1975. "Relation of Offshore and Onshore Mineral Resurces to Plate Tectonics." Proc. Seventh Annual offshore Technology Conference 2: 713-716.

Rona, P.A. 1973. "New Evidence for Seabed Resources from Global Tectonics." Ocean Management 1(2): 145-159.

Rona, P.A. 1973. "Plate Tectonics and Mineral Resources." Scientific American 229(1): 86-95.

Rona, P.A. and L.D. Neuman. 1976. "Energy and Mineral Resources of the Pacific Region in Light of Plate Tectonics." Ocean Management: 57-58.

Rooney, R.F. 1968. "Competitive Bidding for Minera1 Leases." Natura1 Resources Journa1 8: 650-661. 
Roonwa1, G.S. 1986. The Indian Ocean: Exploitable Mineral and Petroleum Resources. New York: Springer-Verlag.

Rose, A.W. 1982. "Mineral Adequacy, Exploration Success, and Mineral Policy in the United States." Journal of Geochemical Exploration 16: 163-182.

Rose, A.W. and R.G. Eggert. 1984. "Planning and Success of Mineral Exploration in the United States." Revised manuscript. Paper presented at Expert Group Meeting on the Economics of Mineral Exploration. Laxenburg, Austria: International Institute for Applied Systems Analysis (December 5-7, 1983).

Rosenbaum, J.B., J.T. May and J.M. Riley. 1969. "Gold in Sea Water--Fact or Fancy." Mines Magazine 59(9): 14-17.

Rosenkranz, R.D., E.H. Boyle, Jr. and K.E. Proter. 1983. Copper Availability--Market Economy Countries. IC 8930. Washington: Minerals Availability Progam Appraisal, U.S. Bureau of Mines.

Rosenqvi, I.T. 1975. "Manganese Nodules of Deep Sea." Internasjonal Politikk $1: 21-25$.

Ross, D.A. 1981. Report on Exploitation of Seabed Resources. Prepared for the United Nations Industrial Development Organization. WHOI, Woods Hole, MA.

Ross, D.A. 1973. "What Common Heritage?" Oceanus 17: 2-5.

Ross, D.A. 1972. "Red Sea Hot Brine Area: Revisited." Science 175: 1455-1457.

Ross, D.A. 1970. Atlantic Continental Shelf and Slope of the United States--Heavy Minerals of the Continental Margin from Southern Nova Scotia to Northern New Jersey. Geologica1 Survey Professional Paper 529-G. Washington: U.S. Govt. Ptg. Ofc.

Ross, D.A. and T.A. Landry. 1987. Marine Scientific Research Bcundaries and the Law of the Sea. Woods Hole, Ma.: International Marine Science Cooperation Program, Woods Hole Oceanographic Institution.

Rothe, P. 1983. "Marine Geology: Mineral Resources of the Sea." Impact of Science on Society 1983(3/4): 357-366.

Rothstein, A.J. 1971. "Deep Ocean Mining: Today and Tomorrow." Columbia Journal of World Business $6: 43-50$.

Roush, G.A. 1939. Strategic Mineral Supplies. New York: McGraw-Hill Book Co.

Routhier, P. 1983. Where Are the Metals for the Future?. The Metal Provinces: An Essay on Global Metallogeny. Orleans, France: Bureau de Recherches Géologiques et Minières. 
Rowland, R.W., M.R. Goud and B.A. McGregor. 1983. The U.S Exclusive Economic Zone--A Summary of its Geology, Exploration, and Resource Potential. USGS Circular 912. Reston, Va.: Geologica1 Survey, U.S. Department of the Interior.

Rowland, T.J. 1986. Federal Government Activities in the U.S. Exclusive Economic Zone. Unpublished manuscript. Washington: U.S. Bureau of Mines.

Ruangsuvan, C. "The Development of Offshore Mineral Resources in Thailand." In D.M. Johnston et a1. (eds.) International Sympsoium on the New Law of the Sea in Southeast Asia. Halifax, Nova Scotia, pp. 82-89.

Saquet, J.J. 1979. "L'Exploitation des Fonds Marins--Ses Imp1ications Internationales." La Symposium Mondiale: Les Relations Publiques de 1'Industrie Miniére. Brusse1s: September 12-15.

Samson, J. 1985. Compilation of Information on Polymetallic Sulfide Deposits and Occurrences off the West Coast of Canada. Draft Working Paper. Ottawa: Energy, Mines and Resources Canada, Ocean Mining Division.

Sanko, P. 1976. "New York Harbor--A Major Sand Pit." Wor1d Dredging and Marine Construction 12(6): 36-37.

Sardar, Z. 1978. "Red Sea Muds Ripe for Exploitation." Nature 275: 582-583.

Sawkins, F.J. 1984. Metal Deposits in Relation to Plate Tectonics. Minerals and Rocks Series, Vo1. 17. New York: Springer-Verlag.

Sax, J.L. 1970. "The Public Trust Doctrine in Natural Resource Law: Effective Judicial Intervention." Michigan Law Review 64: 471-566, (See especially pp. 545-546.)

Schive, P.W. 1984. "The 1982 UN Convention of the Law of the Sea - The Rules Concerning Deep Seabed Mining and the Protection of the Environment." Internasjona1 Politikk 4: 119-26.

Schneider, E.D. 1969. "The Evolution of the Continental Margins and Possib1e Long Term Economic Resources." Proc. First Annual offshore Technology Conference. Vo1. 1, pp. 257-263.

Science Applications, Inc. 1980. Alternatives for Technology Transfer to the Enterprise. Prepared under contract to the U.S. Bureau of Mines, Washington: National Technical Information Service.

Scott, A. 1983. "Property Rights and Property Wrongs". Canadian Journal of Economics 16: 555-73

Scott, A. 1970. "Metals from Water." Engineering. London 209(5415): 163.

Scott, A. et a1. 1984. Progress in Natural Resource Economics. New York: Oxford University Press. 
Sebenius, J.K. 1979. Net Proceeds from Seabed Mining. Draft Report Presented at Group of 77 Seminar on Financial Arrangements. New York: Global Interdependence Center, July 21.

Sebenius, J.K. and P.J.E. Stan. 1982. "Risk-Spreading Properties of Common Tax and Contract Instruments". Be11 Journal of Economics 13: 555-560.

Sebenius, J. K. and M.L. Pa1. 1980. "Evolving Financial Terms of Mineral Agreements: Risks, Rewards and Participation in Deep Seabed Mining". Columbia Journal of World Business 15: 75-83.

Selli, R. 1976. "The Prospects for Mineral Resources of the Italian Sea Floor." Review of the Economic Conditions in Italy 30(3): 193-207.

Setty, M.G. and A. Padmanabha. 1972. "Mineral Resources of the Sea." Mahasagar Bulletin 5(2): 81-91.

Shafer, M. 1982. "Minera1 Myths." Foreign Policy 47: 154-171.

Shimkin, D.B. 1953. Minerals: A Key to Soviet Power. Cambridge, Mass.: Harvard University Press.

Shingleton, B. 1983. "UNCLOS III and the Struggle for Law: The Elusive Customary Law of Seabed Mining." Ocean Development and International Law 13: $33-63$.

Shipkov, Y. 1976. "On Prospects of Gold and Tin Content in Shelf Submerged Valleys. Morskaia Geologiia I Geofizika 5: 51-54.

Shusterich, K.M. 1982. Resource Management and the Oceans: The Political Economy of Deep Seabed Mining. Boulder, Co10.: Westview Press, 344p.

Shusterich, K.M. 1982. "Mining the Deep Seabed: A Complex and Innovative Study." Marine Policy 6: 175-192.

Shusterich, K.M. 1981. The Politics of Deep Seabed Mining: A Case Study in International Resource Management. Ph.D. Dissertation. Santa Barbara, Calif.: Department of Political Science, University of California at Santa Barbara.

Shyam, M.R. 1985. Deep Seabed Mining: An Indian Perspective. Unpublished manuscript. 26th Annual Meeting of the International Studies Association. Washington: March 9.

Shyam, M.R. 1982. Metals from the Seabed: Prospects for Mining Polymetallic Nodules by India. CMA Monograph No. 103. New De1hi: Oxford \& IBH Publishing Co.

Siddiquie, H.N. et a1. 1984. "Superficial Mineral Resources of the Indian Ocean." Deep Sea Research 31: 763-812.

Siddiquie, H.N. and G.V. Rajamanickam. 1979. "Surficial Minera1 Deposits of the Continental Shelf of India." Proc. 1st International Seminar on Offshore Mineral Resources. Orléans, France: GERMINAL and BRGM. 
Siegler, J.C. 1979. "Mining the Sea--the Unrealized Potential." AFL-CIO American Federationist 86(6): 1-6.

Siegesmund, J.C. and J.R. Maxfield. 1985. "Demystifying the Tax Aspects of Development and Depletion." Rocky Mountain Mineral Law Institute 31: 4-1 to $4-36$.

Silverstein, D. 1978. "Proprietary Protection for Deepsea Mining Technology in Return for Technology Transfer--New Approach to Seabeds Controversy." Journal of the Patent Office Society $60(3): 135-70$.

Simpson, E.S.W. 1982. Ocean Science and Non-Living Resources. Report for the Intergovernmental Oceanographic Commission. Halifax: Scientific Committee on Oceanic Research, International Council of Scientific Unions.

Simon, J.L. and H. Kahn. 1984. The Resourceful Earth. New York: Basil Blackwe11.

Sires, B.J. 1986. Federal Offshore 0il \& Gas Leasing: Alaska Outer Continental She1f Region--Document Preparation, Bidding, \& Leasing Procedures. Anchorage, Ak.: Minerals Management Service.

Sirkin, G. 1976. "Resource X and the Theory of Retro-Development." In R.D. Leiter and S.L. Friedlander (eds.) Economics of Resources. Vol. III. New York: Cyrco Press.

Sisselman, R. 1975. "Ocean Miners Take Soundings on Lega1 Problems, Development Alternatives." Engineering and Mining Journal (Apri1): 82.

Skinner, B.J. and K.K. Turekian. 1973. "Man and the Ocean." A.L. McAlester (ed.), Foundations of Earth Science Series. Englewood Cliffs, N.J.: Prentice-Ha11, 155p.

Slade, M.E. 1985. "Rep1y: Noninformative Trends in Natura1 Resource Commodity Prices: U-Shaped Price Paths Exonerated." Journal of Environmental Economics and Management 12: 181-192.

Slade, M.E. 1984. "Tax Policy and the Supply of Exhaustible Resources: Theory and Practice". Land Economics 60(2): 133-147.

Slade, M.E. 1982a. "Empirical Tests of Economic Rent in the U.S. Copper Industry." Advances in the Economics of Energy and Resources 4: 223-239.

Slade, M.E. 1982b. "Trends in Natural-Resource Commodity Prices: An Analysis of the Time Domain". Journal of Environmental Economics and Management 9: 122.

Slade, M.E. 1982c. "Cycles in Natura1-Resource Commodity Prices: An Analysis of the Frequency Domain". Journal of Environmental Economics and Management 9: 138 .

Slansky, M. 1986. Geology of Sedimentary Phosphates. New York: E1sevier. 
Smith, J.B. 1986. Developing a Regulatory Framework for Leasing Minerals on Submerged Federal Lands. Unpublished manuscript. Long Beach, Calif.

Smith, J.B. 1985. "Managing Nonenergy Marine Mineral Development: Analysis of a Program." Proc. Oceans '85. San Francisco.

Smith, J.B., B. Holt and R. Paul. 1985. The Minerals Management Service's Nonenergy Leasing Program for the Outer Continental Shelf/Exclusive Economic Zone. Unpublished manuscript. Long Beach, Calif.

Smith, J.B., B. Holt and R. Pau1. 1985. "Current Status of Leasing Proposals for the U.S. Exclusive Economic Zone." Proc. Offshore Technology Conference 17: 9 .

Smith, J.L. 1982. "Equilibrium Patterns of Competition in OCS Lease Sales." Economic Inquiry 20: 180-190.

Smith, J.L. 1982. "Risk Aversion and Bidding Behavior for Offshore Petroleum Leases." Journal of Industrial Economics 30(3): 251-269.

Smith, P.A. 1972. Underwater Mining--Insight Into Current U.S. Thinking. WIS-SG-72-330. Madison: University of Wisconsin Sea Grant Program.

Smith, V.K. 1979. "Uncertainty and Allocation Decisions Involving Unique Environmenta1 Resources." Journal of Environmental Economics and Management 6: 175 .

Smith, W.J. 1980. "Internationa1 Contro1 of Deep Sea Mineral Resources." In R.B. Lillich and J.N. Moore (eds.) Readings in International Law, pp. 520-528.

Society of Mining Engineers. 1973. Mining Engineering Handbook. New York: American Society of Mining Engineers.

Sorem, R., W. Reinhart and R. Fewkes. 1977. Metal Concentration in Selected Manganese Nodules from DOMES RP-8-0C-76 Box Cores. Report No. PB 275094/AS. Springfield, Va.: National Technical Information Service.

Solow, A.R. In press. "On Estimating Undiscovered Offshore Oil Resources: An Application of Bayes Theorem." Proc. NATO Advanced Seminar Institute on Statistical Treatment for Estimation of Mineral and Energy Resources. Lucca, Italy.

Solow, R.M. 1974. "The Economics of Resources or the Resources of Economics." Am. Econ. Rev. Pap. Proc. 64: 1-14.

Sorensen, P.E. and W.J. Mead. 1970. "Evaluation of Technological Spillovers-The Case of the Deep Sea Dredge." Proc. Sixth Annual Marine Technology Society.

Sorensen, P.E. and W.J. Mead. 1970. "The Principal Costs and Benefits of Marine Mineral Recovery." Proc. Offshore Technology Conference. Houston, Texas. 
Sorensen, P.E. and W.J. Mead. 1969. "A New Economic Appraisal of Marine Phosphorite Deposits off the California Coast." Proc. Fifth Annual Conference of the Marine Technology Society, pp. 491-500.

Sorenson, P.E. and W.J. Mead. 1968. "A Cost-Benefit Analysis of Ocean Mineral Resource Development: The Case of Manganese Nodules." American Journal of Economics and Sociology 50: 1611-1620.

Sowe11, E. 1983. Mineral Access Status of the Federal Lands. Discussion Paper No. 027. Washington: American Petroleum Institute.

Spagni, D. and G. Ford. 1984. "Treasures of the East." Far Eastern Economic Review 123(13): 71-72.

Spangler, M.B. 1970. "New Technology and Marine Resource Development." In New Technology and Marine Resource Development. A Study in Government-Business Cooperation. New York: Praeger.

Spangler, M.B. 1970. "The National Interest--A Case Study of Cupro-Nicke1 Nodules of the Deep Sea." Trans. Sixth Annual Conference of Marine Technology Society: 341-350.

Stark, R.M. and M.H. Rothkopf. 1979. "Competitive Bidding: A Comprehensive Bibliography." Operations Research 27(2): 364-390.

Stavridis, J. 1985. "Resource Wars." U.S. Naval Institute Proceedings (January): 72-77.

Stoever, W.A. 1982. "Endowments, Priorities, and Policies: An Analytica1 Scheme for the Formulation of Developing Country Policy Toward Foreign Investment." Columbia Journal of World Business (Fa11): 3-14.

Stollery, K.R. 1983. "Mineral Depletion with Cost as the Extraction Limit: A Mode1 Applied to the Behavior of Prices in the Nicke1 Industry." Journal of Environmental Economics and Management 10: 151-165.

Straczek, J.A. 1968. "Problems in Offshore Exploration for Tin in Thailand." In E. Keiffer (ed.) Symposium Proceedings of Minera1 Resources of the World Ocean. Narragansett Marine Laboratory Occasional Publication No. 4, p. 66-74.

Strangway, D.W. (ed.). 1980. The Continental Crust and Its Minera1 Deposits. GAC Special Paper No. 20. Water1oo, Ont.: Geological Association of Canada, Department of Earth Sciences, University of Waterloo.

Strauss, S.D. 1983. "Third World Governments and the Mining Industry." NWMA 89th Annual Convention Session Papers. Spokane, Wash.: Northwest Mining Association.

Stuart, J.L. 1982. "Law of the Sea: Unilateral Licensing of Seabed Mining." Harvard Internationa1 Law Journa1 23: 155-163. 
Sujitno, S. 1984. "Exploration for offshore Tin Placer in Indonesia." Proc. 2nd Internationa1 Seminar on Offshore Mineral Resources. Brest, France: GERMINAL, pp. 211-244.

Sujitno, S. 1977. "Some Notes of offshore Exploration for Tin in Indonesia." United Nations ESCAP, CCOP Technical Bulletin 11(October): 169-182.

Sullivan, B. and P. Kobrin. 1978. The Joint Bidding Ban: Pro- and Anti-Competitive Theories of Joint Bidding in OCS Lease Sales. Research Paper 010. Washington: American Petroleum Institute.

Surace-Smith, K. 1984. "United States Activity Outside the Law of the Sea Convention: Deep Seabed Mining and Transit Passage." Columbia Law Review 84(4): 1032-1058.

Sweeney, R.J., R.D. Tollison and T.D. Willett. 1974. "Market -ailure, the Common-Poo1 Problem, and Ocean Resource Exploitation." Journal of Law and Economics 17: 179-191.

Swenson, R.W. 1961. "Development Covenants in Solid Mineral Leases." Natura1 Resources Journa1 1: 271-287.

Swing, J.T. 1980. "American Deep Sea Mining Law and Maritime Law Conference." Europa Archiv. 35(15): 475-482.

Takabayashi, H. 1978. "Exploitation of Seabed Mineral Resources." Business Japan 23(9): 34 .

Takahara, H. et al. 1984. "Research and Development Project of Manganese Nodule Mining System in Japan." Proc. Offshore Technology Conference. Houston: May 7-9.

Takeuchi, T.K. 1983. "Prospect for Deepsea Mining in the 1980's: A Former Industry Member's View." In C.H. Park (ed.) The Law of the Sea in the 1980s, pp. 164-169.

Taney, N.E. 1971. "Comments on Incentives for Ocean Mining - A Case Study of Sand and Grave1." Marine Technology Society Journal 5(4): 41-43.

Taney, N.E. 1968. "Marine Mining Deposits of Economic Interest, Grave1 Sands." Proc. Ocean Mining Symposium, 1967. Sponsored by M.J. Richardson, Inc., p. 189-208.

Tank, R.W. 1983. Legal Aspects of Geology. Plenum Press: New York.

Tapping, T. 1851. The Rhymed Chronicle of Edward Manlove Concerning the Liberties and Customs of the Lead Mines Within the Wapentake of Wirksworth, Derbyshire. 2nd edition. London: Shaw and Sons.

Tarlock, A.D. 1985. "The Making of Federal Coa1 Policy: Lessons for Public Lands Management from a Failed Program, An Essay and Review." Natura1 Resources Journal 25 (Apri1): 349-371. 
Taylor, D.M. 1971. "Converting Worthless Nodules to Valuable Ore." Ocean Industry $6: 27-28$.

Teisberg, T.J. 1980. "Federal Management of Energy and Mineral Resources on the Public Lands." Bel1 Journal of Economics 11(2): 449-465.

Tempest, P. (ed.). 1983. International Energy Markets. Cambridge: Oelgeschlager, Gunn \& Hain; London: Graham \& Trotman.

Tetra Tech, Inc. 1982. Evaluation of Ocean Disposal of Manganese Nodule Processing Waste and Environmental Considerations. Contract Report. Washington: Office of Ocean Minerals and Energy, NOAA, U.S. Department of Commerce and Criteria and Standards Division, Ocean Programs Branch, U.S. Environmental Protection Agency.

Thoburn, J.T. 1981. Multinationa1s, Mining, and Development: A Study of the Tin Industry. Westmead, England: Gower Publishing Company.

Thomas, J. 1965. "Off-Shore Mineral Resources Legislation." Australian Law Journa1 38: 408-417.

Thomas, P.R. and E.H. Boyle, Jr. 1984. Chromium Availability--Market Economy Countries. IC 8977. Washington: Minerals Availability Progam Appraisal, U.S. Bureau of Mines.

Thompson, A.M. III. 1983-84. "Technological Change and the Control of Work: The U.S. Bituminous Coa1 Industry 1865-1930." Economic Forum 14(2): 1-18.

Thompson, R.M. and K.G. Smith. 1970. "Undersea Lode Mining in Alaska." Proc. Second Annual offshore Technology Conference, pp. 819-826.

Tiesberg, T.J. 1980. "Federa1 Management of Energy and Mineral Resources on the Public Lands." Bell Journal of Economics 11(2): 449-65.

Tilton, J.E. 1984. "Summary of a Research Report - The Impact of Seabed Nodule Mining--A Qualitative Analysis." Materials and Society 8(3): 589-92.

Tilton, J.E. 1983. The Impact of Seabed Nodule Mining: A Qualitative Analysis. International Institute for Applied Systems Analysis.

Tilton, J.E. 1983. The Impact of Sea-Bed Minerals: A Qualitative Analysis. Phase I Study. Unpublished manuscript. New York: Ocean Economics and Technology Branch, Department of International and Social Affairs, United Nations.

Tinsley, D. 1983. "Sand and Gravel: Competition and Innovation in English Waters." World Dredging \& Marine Construction (November): 6-11.

Tooms, T.S. 1970. "Metal Deposits in the Red Sea--Their Nature, Origin, and Economic Worth." Underwater Science and Technology Journal 2(1): 28-33. 
Tooms, T.S. 1967. "Marine Minerals in Perspective." Hydrospace, London $1(1): 40,45$ and 46 .

Touret, D.G. 1983. "The French Deep-Sea Mining Legislation of 1981." Ocean Development and International Law 13: 115-120.

Toth, J.R. and C.A. Amerigan. 1986. "Development of an Advanced Sampling Device for the Investigation of Marine Ferromanganese Crust Deposits." Proc. Offshore Technology Conference. Houston, pp. 127-131.

Traavik, K. 1976. "UN Conference on Law of Sea--Fighting for Minerals of Deep Seabed." Internasjonal Politikk 1976(2): 299-320.

Treves, T. 1983. "The Adoption of the Law of the Sea Convention: Prospects for Seabed Mining." Marine Policy 7: 3-13.

Treves, T. 1980-81. "Seabed Mining and the United Nations Law of the Sea Convention." Italian Yearbook of International Law 5: 22-51.

Trondsen, E. and W.J. Mead. 1977. California Offshore Phosphorite Deposits: An Economic Evaluation. Sea Grant Publication 59. IMR Reference 77-106. La Jolla, Calif.: University of California Sea Grant College Program.

Tsurusaki, K. 1986. "Seabed Sand Mining Industry in Japan." Presentation at offshore Sand and Gravel Mining Workshop. Stony Brook, NY: State University of New York.

Tuerkheimer, F.M. 1974. "Copper Mining from Under Lake Superior: The Legal Aspects." Natura1 Resources Lawyer 7: 137-155.

"Union of Soviet Socialist Republics: Edict on Provisional Measures to Regulate Enterprises for the Exploration and Exploitation of Mineral Resources." 1982. International Legal Materials 21: 551-553.

"United Kingdom: Deep Sea Mining (Temporary Provisions) Act 1981." 1981. International Lega1 Materials 20: 1217-1227.

United Nations Environment Program. 1981. "Offshore Drilling and Mining: Aspects Concerning the Environment Related to offshore Drilling and Mining Within the Limits of National Jurisdiction." Environmental Policy 7: $50-52$.

United Nations. 1972. Interregional Seminar on the Development of the Mineral Resources of the Continental She1f, Port-of-Spain, 1971. UN Technical Paper ST/TAO/SER.C/138. New York.

Uren, M. 1986. "The Marine Sand and Gravel Dredging Industry of the United Kingdom." Presentation at Offshore Sand and Gravel Mining Workshop. Stony Brook, NY: State University of New York.

Urquhart, E. 1978. Canadian Nonferrous Metals Industry: An Industrial Organization Study. Kingston, Ont.: Center for Resource Studies, Queen's University. 
Usami, T. et a1. 1979. "Seafloor Sand Mining in Japan." Marine Technology: 176-189.

Van der Voort, J.L. and J.E. Mielke. 1982. Marine Hydrothermal Metal Deposits. Report Prepared by the Congressional Research Service. Seria1 No. 97-D, Committee on Merchant Marine and Fisheries.

Van Dyke, J.M. (ed.). 1985. Consensus and Confrontation: The United States and the Law of the Sea Convention. Honolulu: Law of the Sea Institute.

Van Dyke, J.M. and D.L. Teichmann. 1984. "Transfer of Seabed Mining Technology: A Stumbling Block to the U.S. Ratification of the Convention on the Law of the Sea." Ocean Development and International Law 13: 427-455.

Vanney, J.R. 1980. "L'Exploitation des Nodules Polymétalliques: Une Convergence de Difficultés." Norois 106(April-June): 217-235.

Vard, C. 1983. "La Mise en Valeur des Resources des Mers." Industries et Travaux d'Outre-Mer. (August): 450-465.

Vayrynen, R. 1974. "Struggle for Sea-Bed Minera1s." Instant Research on Peace and Violence 4(4): 206-225.

Ve1zeboer, P.T. 1971. "Some Comments on the Economics of Offshore Mining."

Verleun, L.J. 1984. Base Metal Supply Potential in Northern and Southern Canada: A Comparative Economic Study. Master's Thesis. Kingston, Ont.: Department of Geological Sciences, Queen's University.

Vogely, W.A. 1986. "Why the Strategic Stockpile Should be Abolished." Issues in Science and Technology (Summer): 92-95.

Vogely, W.A. (ed.) 1976. Economics of the Mineral Industries. 3rd Edition. Seeley W. Mudd Series. New York: American Institute of Mining, Metallurgica1, and Petroleum Engineers, Inc.

Waelde, T.W. 1977. "Lifting the Veil from Transnational Mineral Contracts: A Review of Recent Literature". National Resources Forum 1(3): 277-284.

Walk1et, T.H. 1979. "Industrial Pearls: Manganese Nodules: Still Just Out of Reach." Oceans (November): 57-61.

Wallace, I. 1968. "Economic \& Financial Aspects of Ocean Mining Projects." Proc. Ocean Mining Symposium, 1967. Sponsored by M.J. Richardson, Inc., pp. 209-224.

Walthier, T.N. 1971. "Mining Panel Report." Proc. Ocean Science and Technology Advisory Committee Annual Meeting, and National Oceanography Association/National Security Industrial Association Symposium. Washington: Nationa1 Security Industrial Association. 
Walthier, T.N. 1971. "Current Status of Ocean Mining." Mining Engineering 23: $51-53$.

Walthier, T.N., C.E. Schatz and W.L. Griffin. 1968. "Economic Significance of Minerals Deposited in the Red Sea Deeps." EOS, Trans. American Geophysica1 Union 49(1): 193-194.

Wang, F.F.H. and M.J. Cruickshank. 1969. "Technologic Gaps in Exploration and Exploitation of Sub-Sea Mineral Resources." Proc. Offshore Technology Conference. OTC 1031. Dallas.

Wang, F.F.H. and V.E. McKelvey. 1976. "Marine Minera1 Resources." In G.J.S. Govett and M.H. Govett (eds.) World Mineral Supplies, Assessment and Perspective. New York: E1sevier.

Ware, T.M. 1966. "Marine Minerals Mining: Status and Outlook." In Transactions of the Sixth Annual Conference of the Marine Technology Society. Washington, p. 7-13.

Watt, D.C. 1982. "The Law of the Sea Conference and the Deep Sea Mining Issue: The Need for an Agreement." International Affairs 58: 78-94.

Wayland, R.G. 1970. "A Government View of Incentives for Outer Continental Shelf Mining." In Marine Technology 1970, Vo1. 1. Washington: Marine Technology Society.

Webb, B. 1965. "Technology of Sea Diamond Mining." In Transactions of the Joint Conference and Exhibit on Ocean Science and Ocean Engineering 1 \& 2: $8-23$.

Webb, P. 1978. "Lega1 and Economic Aspects of Dredging Marine Aggregates in the U.K." Proc. 1st International Seminar on Offshore Mineral Resources. Brest, France: GERMINAL and BRGM, October 23-27.

Weber, H., K. Pretzsch, C. Barbery and A.W. Fletcher. 1981. "Metallurgical Treatment of Red Sea Concentrates." I0 81-403/01. Proc. Interocean '81: 116-122.

Weeks, L.G. 1967. "Marine Geology: Economic Problems and Prospects." Annals of the New York Academy of Sciences 136: 549-574.

Welling, C.G. 1985. "Mining of the Deep Seabed in the Year 2010." Louisiana Law Review 45(6): 1249-67.

Wenk, E. 1969. "Physical Resources of the Ocean." Scientific American 221(3): 166-176.

Wenk, E. 1968. "A New National Policy for Marine Resources." Natural Resources Lawyer 1(2): 3-13.

Wertenbaker, W. 1983. "The Law of the Sea--I." The New Yorker (August 1, 1983): 38-65. "The Law of the Sea--II." The New Yorker (August 8, 1983): $56-83$. 
Westermeyer, W.E. 1983. "Alternative Regimes for Future Minera1

Resource Development in Antarctica." Ocean Management 8: 197-232.

Weston, R. and C. Silverii. 1985. "The Significance of Futures Trading in Minerals and 0il." Resources Policy (June): 74-86.

White, L. 1984. "Cornish Tin Mining: 1984." Parts 1, 2. Engineering \& Mining Journal. May-June.

White, P.M.T. 1982. "Potential Impact of Manganese Nodule Mining." Trans. Institution of Mining and Metallurgy (Section A: Mining Industry) 91(October): A184-A198.

Wijkman, P.M. 1982. "UNCLOS and the Redistribution of Ocean Wealth." Journal of World Trade Law 16(1): 27-48.

Wilcox, S.M., W.J. Mead and P.E. Sorenson. 1972. "A Preliminary Estimate of the Economic Potential of Marine Placer Mining." Proc. Eighth Annual Conference of the Marine Technology Society, pp. 499-506.

Williams, S.J. 1986. "Sand and Grave1 Deposits Within the United States Exclusive Economic Zone: Resource Assessment and Uses." Proc. Offshore Technology Conference. OTC 5197. Houston: May 5-8.

Willsey, F.P. 1981. "The Deep Seabed Hard Mineral Resources Act and the Third United Nations Conference on the Law of the Sea: Can the Conference Meet the Mandate Embodied in the Act?" San Diego Law Review 18: 509-532.

Wilson J.D. 1982. "Mining the Deep Seabed: Domestic Regulation, Internationa1 Law and UNCLOS III." Tulsa Law Journa1 18: 207-260.

Wilson, T.A. 1965. "Offshore Mining Paves the Way to Ocean Minera1 Wea1th." Engineering and Mining Journal 166(6): 124-132.

Wilson, T. 1965. "Harnessing Systems for Undersea Mining." Engineering and Mining Journa1 166: 62-67.

Wilson, T.A. 1965. "Undersea Mining: A Profile of a Growing Industry." Engineering and Mining Journal 166(5): 82-88.

Wilson, T. 1965. "Offshore Mining Paves the Way to Ocean Mineral Wealth." Engineering and Mining Journal 166: 124-132.

Woodrow Wilson International Center for Scholars. 1971. Ocean Affairs Bibliography. Oceans Series 302. Washington: Smithsonian Institution.

World Dredging Conference Association. 1973. Ocean Mining Symposium: OSM II. San Pedro, Calif.

Wurfel, S.W. 1974. Emerging Ocean 0 il and Mining Law. Sea Grant Publication UNC-SG-74-02. Raleigh: North Carolina State University, 61p.

Wynn, T.C. and A.E. Grosz. 1986. "Application of the Induced Polarization Method to Offshore Placer Resource Information." Proc. Offshore Technology Conference. Houston, May 5-8. 
Yates, J., D. Spagni and J. Keane. 1986. "Marine Mining: Birth of a New Industry." Endeavour (New Series) 10(1).

Yost, K.E. 1983. "The International Seabed Authority Decision-Making Process: Does It Give a Proportionate Voice to the Participant's Interests in Deep Sea Mining?" San Diego Law Review 20: 659-678.

Young, R. 1968. "International Policy Considerations Relating to Ocean Mineral Resources." In Narragansett Marine Laboratory Occasion Publication No. 4. Kingston: University of Rhode Island, p. 104-107.

Zdorovenin, V.V. 1985. "Latest Developments in Ocean Mining: A Potential for New Conflict." Proc. Oceans '85. Seattle: MTS, IEEE. 



\section{DOCUMENT LIBRARY}

August 21, 1987

Distribution List for Technical Report Exchange

Attn: Stella Sanchez-Wade

Documents Section

Scripps Institution of Oceanography

Library, Mail Code C-075C

La Jolla, CA 92093

Hancock Library of Biology \&

Oceanography

Alan Hancock Laboratory

University of Southern California

University Park

Los Angeles, CA 90089-0371

Gifts \& Exchanges

Library

Bedford Institute of Oceanography

P.O. Box 1006

Dartmouth, NS, B2Y 4A2, CANADA

Office of the International

Ice Patrol

c/o Coast Guard R \& D Center

Avery Point

Groton, CT 06340

Library

Physical Oceanographic Laboratory

Nova University

8000 N. Ocean Drive

Dania, FL 33304

NOAA/EDIS Miami Library Center

4301 Rickenbacker Causeway

Miami, FL 33149

Library

Skidaway Institute of Oceanography

P.O. Box 13687

Savannah, GA 31416

Institute of Geophysics

University of Hawaii

Library Room 252

2525 Correa Road

Honolulu, HI 96822

Library

Chesapeake Bay Institute

4800 Atwell Road

Shady Side, MD 20876

MIT Libraries

Serial Journal Room 14E-210

Cambridge, MA 02139
Director, Ralph M. Parsons Laboratory

Room 48-311

MIT

Cambridge, MA 02139

Marine Resources Information Center

Building E38-320

MIT

Cambridge, MA 02139

Library

Lamont-Doherty Geological Observatory

Colombia University

Palisades, NY 10964

Library

Serials Department

Oregon State University

Corvallis, OR 97331

Pell Marine Science Library

University of Rhode Island

Narragansett Bay Campus

Narragansett, RI 02882

Working Collection

Texas A\&M University

Dept. of Oceanography

College Station, TX 77843

Library

Virginia Institute of Marine Science

Gloucester Point, VA 23062

Fisheries-Oceanography Library

151 Oceanography Teaching Bldg.

University of Washington

Seattle, WA 98195

Library

R.S.M.A.S.

University of Miami

4600 Rickenbacker Causeway

Miami, FL 33149

Maury Oceanographic Library

Naval Oceanographic Office

Bay St. Louis

NSTL, MS 39522-5001 



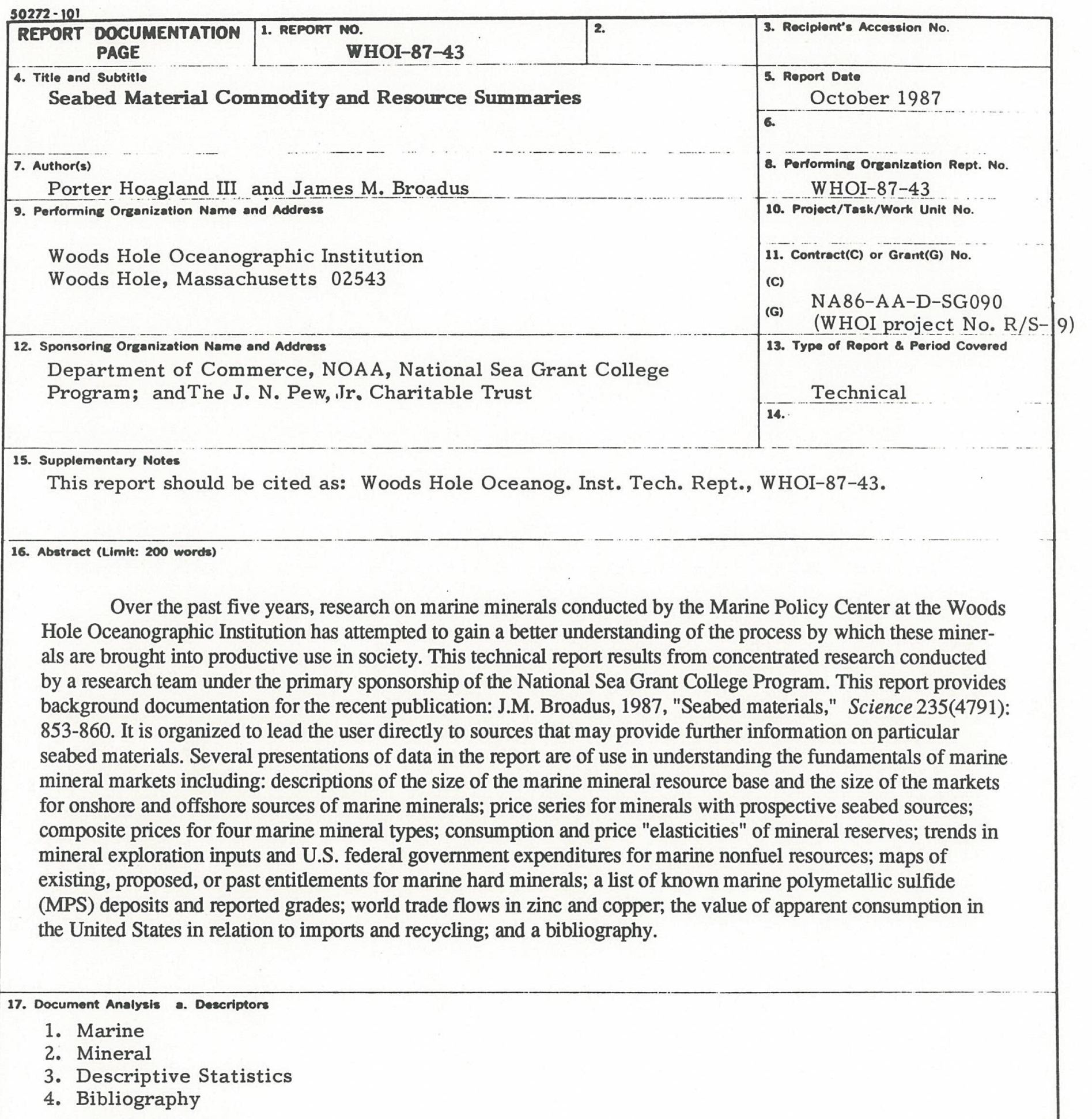

b. Identifiers/Open-Ended Terms

c. COSATI FIeld/Group

18. Avallability Statemen:

Approved for publication; distribution unlimited. 
